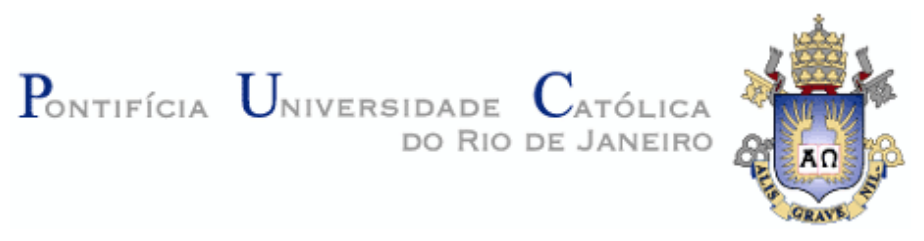

Lua Carvalho de Souza

\begin{abstract}
As Organizações Não-governamentais na Mediação Internacional: Vantagens e Limitações
\end{abstract}

Dissertação apresentada ao programa de pósgraduação do Instituto de Relações Internacionais da PUC-Rio

Orientador: Prof. Kai Michael Kenkel 


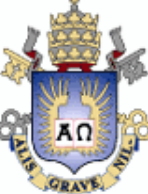

Lua Carvalho de Souza

\section{As Organizações Não-Governamentais na Mediação Internacional: Vantagens e Limitações}

Dissertação apresentada como requisito parcial para obtenção do título de Mestre pelo Programa de PósGraduação em Relações Internacionais do Instituto de Relações Internacionais da PUC-Rio. Aprovada pela Comissão Examinadora abaixo assinada.

Prof. Kai Michael Kenkel Orientador e Presidente Instituto de Relações Internacionais -PUC-Rio

Prof. Paulo Luiz Moreaux Lavigne Esteves Instituto de Relações Internacionais - PUC-Rio

Profa. Marta Regina Fernandes y Garcia Moreno Instituto de Relações Internacionais - PUC-Rio

Profa. Mônica Herz Vice-Decana de Pós-Graduação do Centro de Ciências Sociais -PUC-Rio

Rio de Janeiro, 24 de maio de 2012 
Todos os direitos reservados. É proibida a reprodução total ou parcial do trabalho sem autorização da universidade, da autora e do orientador.

\section{Lua Carvalho de Souza}

Graduou-se em Relações Internacionais na PUC-Rio (Pontifícia Universidade Católica do Rio de Janeiro) em 2009. Sempre desenvolveu projetos e pesquisa relacionados a resolução de conflitos e direitos humanos, principalmente na África.

\section{Ficha Catalográfica}

$$
\begin{aligned}
& \text { Souza, Lua Carvalho de } \\
& \text { As organizações não-governamentais na } \\
& \text { mediação internacional : vantagens e limitações / Lua } \\
& \text { Carvalho Souza ; orientador: Kai Michael Kenkel. - } \\
& 2012 . \\
& 197 \text { f. ; } 30 \mathrm{~cm} \\
& \text { Dissertação (mestrado)-Pontifícia Universidade } \\
& \text { Católica do Rio de Janeiro, Instituto de Relações } \\
& \text { Internacionais, 2012. }
\end{aligned}
$$

1. Relações internacionais - Teses. 2. Organizações não-governamentais. 3. Mediação internacional. 4. Moçambique. 5. Burundi. 6. ACEH. 7. Conflitos complexos. 8. Comunidade Sant'Egidio. I. Kenkel, Kai Michael. II. Pontifícia Universidade Católica do Rio de Janeiro. Instituto de Relações Internacionais. III. Título.

CDD: 327 
Para a minha mãe, Claudia, e minha irmã, Mel, pela paciência e apoio incondicional 


\section{Agradecimentos}

Agradeço a minha mãe, Claudia, e minha irmã, Mel, por me apoiarem incondicionalmente e pela paciência durante os últimos dois anos.

Agradeço ao meu orientador Kai Michael Kenkel por todo o incentivo, paciência e durante toda a orientação recebida desde a graduação e especialmente durante o mestrado e a produção desta dissertação. Além de agradecer-lhe por acreditar neste projeto.

Agradeço a PUC-Rio pelo auxilio concedido, sem o qual este trabalho não poderia ser realizado.

Agradeço aos membros da banca, Paulo Esteves, Reginaldo Nasser e Marta Moreno, por aceitarem compor a banca e proporcionar uma avaliação final e por darem sugestões a este trabalho.

Agradeço a Professora Cristina Margalho pela revisão deste trabalho e as palavras de incentivo.

Agradeço a Regina Codeço pela revisão e conselhos de português que ajudaram imensamente a esta dissertação chegar ao seu fim.

Agradeço ao Nizar Messari por acreditar primeiramente neste projeto e incentivar a minha entrada no mestrado.

Agradeço a minha turma de mestrado pelo incentivo e companheirismo nesses dois anos, especialmente a Cristiane Oliveira, Daniele Nepomuceno e Francine Rossone. Eles sabem melhor do que ninguém o que significa a entrega desta dissertação.

Agradeço as minhas amigas, Adriana Sarkis, Flavia Speiski, Lívia Salles, Juliana Damazio, Emilia Jomalinis, por todo o incentivo e por ter me suportado nos momentos de desabafos durante todo o mestrado.

Agradeço Michelle Millen. Thais Gurjão e Camila Coelho por estarem sempre me apoiando e por terem me incentivado durante este longo projeto.

Agradeço ao meu departamento na ActionAid Brasil por entender todas as horas que tive que dedicar a esta dissertação e por todo incentivo. Muito obrigada, Beatrice Freitas, Celia Bartone, Daniele Rocha, Daniel Vasconcellos, Edilaine Helena Andrade e Vânia Franca. 


\section{Resumo}

Souza, Lua Carvalho; Kenkel, Kai Michael. As Organizações NãoGovernamentais na Mediação Internacional: Vantagens e Limitações. Rio de Janeiro, 2012. 197p. Dissertação de Mestrado - Instituto de Relações Internacionais, Pontifícia Universidade Católica do Rio de Janeiro.

A mediação internacional transformou-se nas últimas décadas devido a dois fatores: as mudanças nas características do conflito armado; e a entrada de novos atores. Os conflitos modificaram-se significativamente após o fim da Guerra Fria, apesar de já ser possível encontrar sinais destas transformações desde a década de 70. A entrada de novos atores, dos quais se destacam principalmente organizações não-governamentais (ONGs), foi uma resposta a essas novas necessitadas do conflito, a modificações na relação dos Estados com as ONGs e destas no campo da resolução de conflitos. As ONGs proporcionaram novas possibilidades à mediação internacional, abrindo o leque de possíveis soluções aos conflitos, por conseguirem atingir todos os níveis sociais durante o processo de resolução. As ONGs possibilitaram com que a mediação envolva toda a sociedade e desenvolva-se um longo processo de reconciliação. No entanto, como todo o mediador elas possuem vantagens e limitações que devem ser consideradas no momento da mediação. Além disso, é necessário ressaltar que a mediação pode envolver mais de um ator ou até mesmo mais de de um tipo de ator, desde que a ação deles seja coordenada. Objetivando analisar isto esta dissertação utilizará de três casos de estudo: Moçambique, Aceh e Burundi e as suas mediações.

\section{Palavras chaves}

organizações não-governamentais; mediação internacional; conflitos complexos; Moçambique; Aceh; Burundi; Comunidade SantEgidio; Center for Conflict Resolution; Henry Dunant Center for Humanitarian Dialogue; Conflict Management Initiative; Search for Common Ground 


\section{Abstract}

Souza, Lua Carvalho de; Kenkel, Kai Michael. No-Governmental Organization in International Mediation: Advantages and Limitations. Rio de Janeiro, 2012. 197p. MSc. Dissetation - Instituto de Relações Internacionais, Pontifícia Universidade Católica do Rio de Janeiro.

International mediation has been transformed over the last decades, primarily through two factors: the changed characteristics of armed conflict and the emergence of new actors. Conflicts were significantly modified after the Cold War, but races of these transformations can be found as early as the 1970s. The entry of new actors, principally Non-Governmental Organizations (NGOs), was a response to the exigencies of new conflict situations, and was due to the modification of the relationship between states and NGOs in the resolution of conflicts. Given this situation, this thesis analyzes the advantages and limitations of NGOs as international mediators, focusing on their role in three major conflicts: Mozambique, Aceh and Burundi.

\section{Keywords:}

Non-Governmental Organization; International Mediation; Complex Conflict; Mozambique; Aceh; Burundi; Community of SantEgidio; Center for Conflict Resolution; Henry Dunant Center for Humanitarian Dialogue; Conflict Management Initiative; Search for Common Ground 


\section{Sumário}

1. Introdução

2. A natureza da guerra e a mediação internacional 17

$\begin{array}{lr}\text { 2.1. A natureza da guerra } & 17\end{array}$

2.1.1. Transformações da guerra no pós Guerra Fria e 11 de 18 setembro

2.1.2. As características dos conflitos complexos 20

2.1.2.1. Globalização e regionalismo 22

$\begin{array}{ll}\text { 2.1.2.2. Estados falidos } & 24\end{array}$

2.1.2.3. Características dos conflitos complexos 28

2.1.3 Os conflitos complexos e a mediação internacional 33

2.2. A mediação internacional 36

$\begin{array}{ll}\text { 2.2.1 Definições } & 37\end{array}$

2.2.2 Histórico da mediação internacional 39

2.2.3 Tipos de mediação $\quad 40$

2.2.3.1. A mediação tradicional $\quad 45$

2.2.3.2. A mediação de segunda via 46

$\begin{array}{ll}\text { 2.2.3.3. Mediação multipartidária } & 47\end{array}$

2.2.4 Tipos de mediadores $\quad 49$

$\begin{array}{ll}\text { 2.2.4.1. Indivíduos } & 49\end{array}$

$\begin{array}{ll}\text { 2.2.4.2. Estados } & 49\end{array}$

2.2.4.3. Organizações internacionais e regionais 50

2.2.4.4. Organizações não - governamentais (ONGs) 52

2.2.5 Comportamento dos mediadores $\quad 54$

2.2.5.1.Imparcialidade $\quad 55$ 
$\begin{array}{ll}\text { 2.2.5.2. Perspectiva } & 57\end{array}$

$\begin{array}{ll}\text { 2.2.5.3. Poder } & 60\end{array}$

$\begin{array}{ll}\text { 2.2.6 Estratégia do mediado } & 63\end{array}$

$\begin{array}{ll}\text { 2.2.7 Motivação do mediador } & 65\end{array}$

2.2.8 Atividades e funções do mediador 66

$\begin{array}{ll}\text { 2.3. Conclusão } & 70\end{array}$

3. Organizações não-governamentais como mediadoras 74 internacionais

3.1. A entrada das organizações não-governamentais na 75 mediação internacional

3.2. O relacionamento das organizações não-governamentais e os 76 Estados

3.3. Organizações não-governamentais no papel de mediadoras 78 principais

3.4. As vantagens das organizações não-governamentais na mediação internacional

3.5. As limitações das organizações não-governamentais na mediação internacional 
5.3. O conflito 132

5.4. A resolução 141

5.5. Conclusão 145

$\begin{array}{ll}\text { 6. Burundi } & 148\end{array}$

6.1. Center for Conflict Resolution 148

6.2. Search for Common Ground 150

6.3. O conflito 151

6.4. Resolução 160

$\begin{array}{lr}\text { 6.5. Conclusão } & 169\end{array}$

$\begin{array}{ll}\text { 7. Conclusão } & 173\end{array}$

8. Referências Bibliográficas 188 


\section{1. \\ Introdução}

Desde o final da Guerra Fria, observa-se um significativo aumento na abertura do campo de resolução de conflitos para uma variedade de novos atores. Pequenos Estados entraram dispostos a comprometer tempo e recursos para promover a paz no sul da Ásia, no Oriente Médio, na América Central e na África. As Nações Unidas, juntamente com um crescente número de organizações regionais, vêm aumentando a sua ação no campo, após o congelamento do Conselho de Segurança. Contudo, numericamente, o maior crescimento na inserção de novos atores é no campo dos não-oficiais ${ }^{1}$. A composição do grupo dos não oficiais é tão diversificada, que engloba atividades de prevenção de conflito, reconciliação e pós-conflito, conseguindo assim envolver-se em todos os ciclos do conflito. As organizações não-oficiais, que se dedicam à pacificação, são de diferentes tamanhos, recursos, capacidades e flexibilidades. (AALL, 2007, p.477)

Vale destacar, todavia, que, nessa dissertação, privilegiaremos somente as organizações não-governamentais (ONGs), as quais já possuem uma difícil definição devido à inconsistência do termo. Em 1950, o ECOSOC (Conselho Econômico e Social das Nações Unidas) utilizou pela primeira vez a definição de ONGs como organizações sem fins lucrativos e sem nenhum vínculo institucional com um governo e iniciadas devido ao interesse de grupos comuns, dispostos a formar uma entidade. Peter Willetts, professor da City University of London, argumenta que a definição de ONGs pode ser interpretada de diferentes maneiras por diferentes organizações e depende do contexto. Nesse sentido, ele define ONG como "associação voluntária e independente de pessoas que visam a objetivos comuns, os quais se distinguem de escritórios governamentais, objetivos financeiros e atividades ilegais". (WILLETTS, 2002) Ou seja, a orientação das ONGs refere-se as suas atividades que podem ser de desenvolvimento, meio ambiente, ou trabalho de advocacia. O nível de operação das ONGs indica a

\footnotetext{
${ }^{1}$ Atores não-oficiais incluem atores do setor privado; parceiros econômicos e sociais, incluindo associações sindicais, a sociedade civil em todas as suas formas de acordo com as características nacionais. (CLAPHAM, 2009, p. 205) O grupo dos atores não oficiais é tão amplo que engloba organizações nacional e internacional, pequena ou grande. Inclui também as instituições com forte vínculo com os atores oficiais e os que atuam somente na sociedade civil. (AALL, 2009, pp. 477478)
} 
escala na qual elas trabalham, havendo diferenças no trabalho de ONGs internacionais e ONGs nacionais e comunitárias. No entanto, todas as ONGs estudadas nesta dissertação trabalham em nível internacional. (VALKIL, 1997, pp. 2057-2070)

A mudança significativa na natureza dos conflitos armados foi outra consequência do fim da Guerra Fria. Apesar de podermos identificar algumas características dos conflitos complexos desde a década de 70, somente no conflito da Bósnia é que esse tipo de conflito chamou a atenção do sistema internacional e passou a ser considerado um dos maiores problemas da segurança internacional. Os conflitos passaram da tradicional luta entre Estados pelo centro do poder para lutas internas no Estado, das quais Estados falidos são os grandes protagonistas, sendo esta característica uma das principais motivações para a entrada de novos atores no cenário da resolução e prevenção de conflitos. As lutas internas realizadas, às vezes, por grupos étnicos, religiosos e vizinhos têm um intenso impacto em toda a sociedade em conflito. Deve-se considerar que muitas vezes as consequências dos conflitos internos transbordam a fronteira nacional, impactando os Estados vizinhos, como por exemplo, o caso dos refugiados. Esses impactos externos podem levar com que os Estados impactados se interessem pelo conflito, devido aos problemas causados pelo combate.

As Nações Unidas não tiveram a capacidade de impedir os conflitos complexos de acontecerem, em parte devido às limitações dos mecanismos institucionais desenhados para lidar com os conflitos tradicionais e, portanto, incapazes de lidar com os conflitos complexos de forma eficaz. Em decorrência disso, a inclusão de novos atores no mecanismo de resolução de conflitos é importante. Atualmente, representantes dos atores não-oficiais, tais como ONGs ou grupos de cidadãos, realizam uma série de funções complementares ou paralelas às relações oficiais interestaduais ou de organizações internacionais, sendo que, em alguns casos, atuam como o principal mediador do conflito, como são os casos estudados nesta dissertação. As ONGs podem ajudar a melhorar as relações entre os diferentes grupos em vários níveis. Contudo, como os demais mediadores internacionais, as ONGs enfrentam desafios dos quais precisam estar cientes e superá-los para melhorar a sua eficácia na mediação internacional. A principal limitação, que deve ser sobrepujada e não afeta somente as ONGs, mas todos os conflitos que possuem mais de um mediador, é a falta de coordenação 
entre os diferentes atores atuantes no conflito. (RITTBERGER; BRUHL, 2001, p. 24)

A resolução de conflitos dos chamados conflitos complexos não tem como seguir a estrutura tradicional, organizada de forma linear. Pois, a mediação precisa responder ao processo caótico da nova natureza do conflito, ou seja, ela precisa ser descentralizada, flexível, adaptável e capaz de trabalhar em diferentes níveis da sociedade com o objetivo de reconstruir e reconciliar toda a sociedade. Esta nova perspectiva deve ser adotada por todos os atores da mediação, porque estes têm que possuir o discernimento para escolher os melhores mediadores que devem ser incluídos em cada caso. (AALL, 2007, p. 478)

Nesse sentido, o objetivo desta dissertação é analisar a participação das ONGs na mediação internacional dos conflitos complexos, por meio do estudo das regras e normas de mediação internacional, percebendo assim como as ONGs conseguem enriquecê-la, acrescentando novas práticas e normas exclusivas. Importa, ainda, destacar a importância da participação das ONGs na solução de conflitos internacionais, com principal atenção aos novos conflitos, devido a sua complexidade e aos desafios apresentados por esse tipo de conflito. As ONGs conseguem lidar com esses novos desafios através de características específicas, tornando-as mais aptas nas mediações. Nesse sentido é fundamental analisar as vantagens e limitações das ONGs na mediação internacional, considerando que todos os tipos de mediadores as possuem, o que deve ser profundamente analisado no momento da mediação. Para clarificar essa analise, três estudos de casos serão feitos: Moçambique, Aceh e Burundi, respectivamente nos capítulos 3,4 e 5.

A escolha da ordem dos capítulos não foi arbitrária: os primeiros dois capítulos tratarão da parte teórica da dissertação, sendo que o primeiro dividido em duas partes claras: a primeira aborda a teoria de conflitos e mudança nos conflitos; e a segunda, a teoria de mediação internacional. Em continuidade, a parte teórica da dissertação o segundo capítulo aprofunda a participação das ONGs na mediação internacional.

Os três capítulos referentes aos estudos de caso possuem a sua ordem definida pelas diferenças e similaridades dos conflitos, ficando o do Burundi ficando por último devido ao insucesso da sua mediação. $\mathrm{O}$ conflito de Moçambique é realizado por somente uma ONG, a Comunidade Sant'Egidio, e 
possui as principais qualidades da mediação, tal como o envolvimento prolongado no conflito, primeiramente como humanitário e posteriormente como a principal mediadora. O segundo conflito analisado, o do Aceh, teve duas rodadas de mediação: a primeira realizada pela Henry Dunant Center for Humanitarian Dialogue, que foi malsucedida e a segunda pelo Conflict Management Initiative, sendo este bem-sucedido. Considerando as duas rodadas de mediação, este conflito consegue englobar mais aspectos positivos e negativos da mediação de ONG e por causa disto fica no capitulo 4. Já a mediação no Burundi foi realizada por três ONGs, Comunidade Sant'Egidio, Center for Conflict Resolution, Search for Common Ground em diferentes situações - considerando que a Comunidade estava trabalhando junto com os mediadores principais e o Center for Conflict Resolution e o Search for Common Ground faziam um trabalho mais relacionado com mediação de segunda via. Nesse conflito pode-se perceber mais claramente as limitações da mediação de ONG, permitindo assim englobar todos os aspectos da mediação de ONGs nos estudos de caso.

Diante de tais propostas, esta dissertação está organizada sob a forma de cinco capítulos - desconsiderando-se a introdução e a conclusão. O primeiro capítulo dedicar-se-á à parte teórica em relação à natureza do conflito e as suas mudanças; e a mediação internacional e suas modificações ao longo dos anos, com especial atenção no pós Guerra Fria. Abordará as mudanças na natureza da guerra, bem como na mediação internacional. Também discutirá as mudanças na guerra no pós Guerra Fria; quais são os modelos de mediação e qual melhor adéqua-se aos conflitos complexos; os tipos de mediadores, o seu comportamento, as suas motivações, suas estratégias, e tarefas e funções. Cabe lembrar que a mediação é uma forma de resolução de conflito que objetiva que ambas as partes assumam compromissos e troquem experiências entre si, sem declarar a existência de um vencedor.

O segundo capítulo analisará as ONGs na mediação internacional. Devido a isto é necessário abordar alguns pontos fundamentais para a entrada e permanência delas no campo da resolução de conflitos. Primeiramente é necessário apresentar como as ONGs envolvem-se na resolução de conflitos. Em segundo lugar, as mudanças na relação dos Estados e das ONGs, o que tem forte influência na transformação do papel das ONGs na resposta ao conflito armado. Em terceiro lugar, é fundamental destacar não somente como elas entram no 
campo de resolução de conflito, mas também como elas tornaram-se as principais mediadoras nos conflitos. Por último, os dois tópicos finais destinam-se às vantagens e limitações das ONGs, respectivamente. Esta é a principal parte do capitulo e é onde se encontra o argumento central de que todo mediador possui vantagens e limitações que devem ser analisadas profundamente no momento da mediação.

No terceiro capítulo inicia-se a parte empírica da dissertação, que é divida em três capítulos. O terceiro capítulo dedicar-se-á ao conflito de Moçambique e a bem-sucedida mediação da Comunidade Sant'Egidio. A Comunidade Sant'Egidio tinha um relacionamento longo com a FRELIMO (Frente de Libertação de Moçambique) e a RENAMO (Resistência Nacional Moçambicana) podendo basear o seu processo de mediação no seu relacionamento de confiança e profundo conhecimento com as partes, para com isso conseguir legitimar a sua posição e conseguir poderes específicos que seriam utilizados no processo de resolução do conflito. Além disso, a Comunidade conseguiu captar outros atores para a mediação sob a sua coordenação, tais como o governo italiano e o Vaticano. A Comunidade Sant'Egidio conseguiu mediar um conflito que já levado a morte de aproximadamente um milhão de pessoas (LEITENBERG, 2006, p. 15), sendo que destas 95\% eram civis. (BRÜCK, 1998, p. 1037)

O quarto capítulo refere-se ao conflito do Aceh, uma região da Indonésia que reivindicava sua independência. A mediação desse foi realizada por duas ONGs em momentos diferentes. A Henry Dunant Center for Humanitarian Conflict, no início de 2000 tentou mediar o conflito, mas devido à situação internacional e interna não conseguiu sucesso. Após o tsunami de 2004, que deixou 170 mil mortos ou desaparecidos no Aceh, a Conflict Management Initiative iniciou a sua mediação bem-sucedida. Naquela ocasião, pós-Tsunami, a atenção mundial voltou-se para esta região e ficou mais fácil captar outros atores para se envolverem na mediação. Diante desse conflito demonstra-se que em muitas situações é imprescindível que outros atores, além das ONGs, participem da mediação.

O quinto capítulo trata do conflito do Burundi, que se pode considerar como iniciado em 1972, apesar dos longos períodos de intervalo entre os conflitos armados. A mediação foi realizada pela Comunidade Sant'Egidio e o Center for Conflict Resolution, da África do Sul, juntamente com o Search for Common 
Ground. A Comunidade Sant'Egidio participou da mediação principal e estava junto com o ex-presidente da Tanzânia, Julius Nyerere, e, posteriormente, Nelson Mandela, os mediadores principais do conflito. Em contrapartida, O Center for Conflict Resolution, juntamente com o Search for Common Ground, realizou principalmente uma mediação chamada como segunda via. A mediação não foi bem-sucedida e o conflito continua apesar de alguns avanços conseguidos nas tentativas de transformar o conflito de armado em político.

$\mathrm{Na}$ conclusão, analisar-se-á como as vantagens e as limitações das ONGs podem contribuir para a mediação internacional à luz das três mediações estudadas nesta dissertação, as características dos conflitos complexos e as características da mediação. 


\section{2.}

\section{A natureza da guerra e a mediação internacional}

O capítulo, que ora se apresenta, é divido em dois pontos focais. A primeira parte focará a definição da guerra ${ }^{2}$ e suas mudanças ao longo das últimas décadas, considerando particularmente os principais desafios presentes nos atuais conflitos $^{3}$ complexos. Os conflitos complexos são fundamentais na dissertação, pois possuem características particulares, perante as quais a mediação tradicional, que era usada predominantemente durante a maior parte da história contemporânea, não consegue adequar-se e, consequentemente, alcançar a solução desejada.

A segunda parte deste capítulo dedica-se a mediação internacional e suas características. A mediação internacional adaptou-se a atual natureza do conflito e à inclusão de novos atores, como as ONGs. Pois, as ONGs, que funciona como novo ator da mediação internacional, possuem características especiais que proporcionam vantagens consideráveis nos conflitos complexos, as quais serão debatidas mais profundamente no segundo capítulo, visto que elas abordam a mediação internacional em uma perspectiva mais particular e diferenciada. Em contrapartida, as ONGs têm desvantagens, como qualquer outro mediador internacional, como será melhor analisado no quarto capítulo. O debate iniciado durante o primeiro capítulo aprofunda-se nos dois capítulos subsequentes.

\subsection{A natureza da guerra}

O conflito internacional modificou-se consideravelmente após o fim da Guerra Fria. Apesar de existirem indícios que o conflito já estava se modificando desde a década de 70, a guerra da Iugoslávia é o marco inicial para a existência dos conflitos complexos.

\footnotetext{
${ }^{2}$ A guerra é um conflito armado intencional e generalizado entre comunidades políticas, as quais podem ser nações, Estados e as partes, por espaço de tempo considerado. A definição de guerra está intimamente relacionada a teoria da guerra justa, a qual pode ser dividida em três partes: 1) Just ad bellum - refere as regras para recorre-se a guerra; 2) Just in bello- são as regras durante o período de guerra; e 3) Just post bellum - referindo-se as regras após o termino da guerra. (STANFORD ENCYCLOPEDIA OF PHILOSOPHY, 2005)

${ }^{3} \mathrm{O}$ conflito é a discordância através da qual as partes envolvidas percebem uma ameaça as suas necessidades, interesses ou preocupações. Observa-se então, que o conflito pode ou não ser armado. (ACADEMIC LEADERSHIP SUPPORT, 2000)
} 
A presença da Guerra Fria no cenário internacional fazia com que as atenções e recursos estivessem voltados para ela por ter sido o conflito mais importante do sistema internacional. No entanto, a Guerra da Iugoslávia fez com que o mundo percebesse a predominância de conflitos internos e com características completamente diferentes das guerras tradicionais.

Atualmente, a África e o sul da Ásia destacam-se com a maior predominância de conflitos complexos devido à construção recente do Estado nestas localidades, o que será aprofundado posteriormente. Os conflitos complexos possuem características próprias, tais como: a estratégia de guerrilha com a predominância de armas leves; o ataque a civis como arma de guerra; a destruição da infra-estrutura do Estado; a multiplicidade de forças no conflito, as quais são extremamente subdivididas.

\subsubsection{As transformações da guerra no pós Guerra Fria e 11 de setembro}

O fim da Guerra Fria e a dissolução da União Soviética puseram fim a um longo período histórico no qual existia somente um grande conflito internacional, que dominava o sistema internacional, com os conflitos de procuração e com a polarização das forças. Mudanças puderam ser sentidas em todo o cenário internacional, na organização das Nações Unidas, na relação ONG - Estados, nos conflitos internacionais e nas respostas dadas a eles.

A mudança no cenário internacional com o fim da Guerra Fria teve consequências dentro da ONU. A transformação mais sentida foi no comportamento do Conselho de Segurança, o qual anteriormente tinha perdido a sua força de decisão devido aos sucessivos vetos por parte dos Estados Unidos e a Rússia, enquanto União Soviética. A mudança na postura do Conselho de Segurança foi necessária e fundamental para conseguir responder aos novos desafios do cenário internacional, com conflitos complexos e de natureza diferenciada dos que até aquele presente momento o sistema internacional tinha enfrentado. A mediação, como outras respostas ao conflito, no contexto apresentado, não podia ser a mesma utilizada até então. (RAMSBOTHAM; WOODHOUSE: MIALL, 2009, p. 17) 
Nesse sentido, era imperativo que mudasse a resposta dada aos conflitos, já que a resposta aos conflitos desenvolvida até então pela ONU, Estados, acadêmicos e todos os atores - que a compunham - detinha-se nos conflitos compreendidos como tradicionais, entre Estados. Os estudos eram baseados em conflitos entre Estados; com líderes que possuíam legitimidade para realizar as negociações e frente à população para, posteriormente, implementar o acordo; com forças determinadas e organizadas; distanciamento entre civis e militares; respeito ou punição frente ao Direito Internacional e às regras estabelecidas nas Convenções de Genebra e seus Protocolos Adicionais ${ }^{4}$, os quais não permitiam que alguns atos fossem cometidos durante a guerra. A guerra tradicional era separada da paz por atos legais, tal como a declaração de guerra e o acordo de paz. (MÜNKLER, 2004, pp. 11-13)

O fim da Guerra Fria desanuviou os conflitos internos, que já vinham ocorrendo desde o fim da Segunda Guerra Mundial, mas eram sublimados ou cooptados pelo grande conflito presente no cenário internacional. Desde o fim da Segunda Guerra Mundial que guerras civis e mistas, que englobavam o conflito interno e internacional, vêm substituindo as guerras internacionais convencionais como a principal forma de violência no sistema internacional, ou seja, uma gama de características presentes nos conflitos complexos já estava presente das décadas anteriores do fim da Guerra Fria, como mostra, por exemplo, o aumento considerável dos refugiados na década de 70. (RAMSBOTHAM; WOODHOUSE: MIALL, 2009, p. 83)

No entanto, mesmo que se aceite que as guerras internas ou complexas sejam predominantes no sistema internacional desde 1945, a fase pós-Guerra Fria é diferente do que foi vigente, visto que as rivalidades não eram mais parcialmente moldadas pela estrutura das superpotências. Por essa razão, apesar de alguns conflitos terem sido formalmente levados a um fim na década de 90 , pela retirada de apoio externo para os partidos de guerra e de pressão pelo acordo

\footnotetext{
${ }^{4}$ As Convenções de Genebra e seus Protocolos Adicionais são a essência do Direito Internacional Humanitário, formam o conjunto de leis que regem a conduta no conflito armado e tenta limitar os seus efeitos. Eles protegem especialmente os não-combatentes, ou seja, as pessoas que não participam do conflito (civis, profissionais da saúde e de socorro) e os que não participam mais do conflito (soldados feridos, náufragos, doentes e prisioneiros de guerra). A Convenção de Genebra foi assinada em 1949, após o fim da Segunda Guerra Mundial, e tinha como pretensão impedir que os horrores sofridos naquele conflito não se repetissem. Já os Protocolos Adicionais foram assinados em 1977 e 2005. (CICV, 2005)
} 
de paz, outros se acenderam, mudaram de caráter ou tornaram-se mais caóticos no vácuo de poder subsequente. (pp. 70-71)

O agravamento do conflito no fim da Guerra Fria deu-se porque, durante a Guerra Fria, a intervenção das duas Grandes Potências nos conflitos tendia a concentrar o poder e a força em duas frentes, normalmente divididas entre a força do governo e na dos rebeldes. Em decorrência, com o fim da Guerra Fria, as

forças que lutavam nos países do terceiro mundo se fragmentaram devido à retirada do apoio militar e econômico das duas potências, criando grupos incontáveis de poder e força, os quais possuíam objetivos diversos. (NATSIOS, 2007, p. 338) A fragmentação não teve como único motivo a retirada do apoio das grandes potências; outra consequências provocada pelo fim da Guerra Fria foi o fim da polarização das forças.

Em muitos países, principalmente africanos e do Leste europeu, a retirada do apoio econômico das duas grandes potências e do apoio das grandes potências juntamente com a intensificação da pressão financeira internacional para a liberalização econômica e política tiveram como consequência a precipitação do enfraquecimento dos sistemas autoritários. (RAMSBOTHAM; WOODHOUSE: MIALL, 2009, p. 98)

\subsubsection{As características dos conflitos complexos}

Nas últimas décadas, mudanças significativas ocorreram na natureza e no significado do conceito de segurança internacional. Os conflitos mudaram, exigindo novos estudos, abordagens sobre a guerra, suas características e modos de lidar com ela.

O conflito tradicional era compreendido como centrado no Estado ${ }^{5}$, interestatal, motivado por separatismo, causas políticas e luta pelo controle do poder. Consequentemente, a resolução desses conflitos era baseada na mesma lógica, priorizando o Estado e seus governantes, os quais possuíam legitimidade para implementar o acordo feito por eles em todo o território nacional e sobre a população. Em decorrência disso, a mediação era realizada principalmente por

\footnotetext{
${ }^{5}$ O Estado é compreendido como organização política construída socialmente, e é caracterizado pelo:monopólio do uso da força, legitimidade, estrutura institucional estabelecida para lidar com as obrigações governamentais e o controle total ou parcial do território. (RASMUSSEN, PETER RAVN, 2001)
} 
Estados, organizações internacionais e regionais, pois eles possuíam força econômica e militar, que eram as mais valorizadas, naquele momento, para incentivar ou obrigar a implementação do acordo. (BUTLER, 2009, p. 53)

No entanto, nas últimas décadas do século XX e nas primeiras duas décadas do século XXI, as mudanças no cenário internacional e na formação dos Estados mudaram a natureza do conflito e, consequentemente, observou-se a necessidade de mudar a resposta dada a ele e os estudos feitos a partir deles, o que ficou mais evidente após a Guerra da Iugoslávia. A guerra entre Estados decresceu e emergiu um novo tipo de conflito, interno, no cenário de análise. (MÜNKLER, 2004, p. 5)

Edward Azar aponta três aspectos que, até então, tinham sido uma ortodoxia dominante no estudo de guerra, e que não funcionam no estudo dos conflitos complexos atuais. Primeiramente, houve uma tendência de compreender os conflitos a partir de dicotomias bastante rígidas das dimensões interna e externa com sociólogos, antropólogos e psicólogos preocupados com o primeiro - guerras civis, insurreição, golpes, protestos, revoltas, revolução, entre outros - e estudiosos de relações internacionais com o segundo - guerras interestatais, crises, invasões, conflitos de fronteira, bloqueios, entre outros.

Em segundo lugar, os quadros vigentes de análise tinham sido muitas vezes baseados na diferenciação funcional de aspectos e tipos de conflito em subcategorias: psicológicas, sociais, conflitos políticos, econômicos e militares e em diferentes "níveis de análise".

Em terceiro lugar, houve a tendência de concentrar os estudos em conflitos abertos e violentos, ignorando o conflito encoberto, latente ou não-violento; e a dinâmica do conflito, em termos de ciclos de conflito, era compreendida pelos atos de violência em contraposição aos estados de paz, contratando com o que sugere o estudo de conflito social prolongado, no qual se aponta que muitos conflitos, atualmente ativos nas regiões subdesenvolvidas do mundo, são caracterizados por uma demarcação turva entre fontes internas e externas e atores. Além disso, existem vários fatores causais e dinâmicos, os quais refletem a mudança de objetivos, atores e metas. Finalmente, estes conflitos não possuem um ponto de início e fim claros. (AZAR, 1990, p. 7)

Os estudos desse novo tipo de conflito e a resposta que se dará a eles devem considerar também a estrutura do cenário internacional, cuja globalização aponta para novos desafios. A região exerce uma forte influência em incentivar ou 
regredir o conflito e a construção recente dos Estados, cuja colonização e independência deixaram marcas profundas é outro fator a ser analisado.

\subsubsection{Globalização e regionalismo}

A globalização gera interações e fragmentações nas relações; principalmente no que tange às relações humanas esse foi um elemento importante do contexto em que os conflitos complexos surgiram. (BUTLER, 2009, p. 58) A globalização, juntamente com o reforço das normais internacionais, tal como a autodeterminação dos povos, também tem efeito na construção do Estado fazendo com que surjam Estados fracos e dependentes. (CARMENT, 2003, p. 413)

A globalização contribui fortemente para a existência de Estados falidos e os conflitos situados nestes territórios. Os Estados falidos não se encontram nesta situação somente devido à lealdade estar fragmentada em autoridades locais, étnicas e de identidade, ou devido à inadequada hierarquia social e à integração social, mas devido aos efeitos devastadores da globalização nos Estados que não são robustamente constituídos. Isto porque os Estados não conseguem controlar o seu desenvolvimento nacional dentro do mercado internacional e as riquezas nacionais, tais como diamantes, petróleo, gás e minérios, não contribuem para o desenvolvimento sustentável dessas nações. Ao contrário, estes recursos contribuem como motivação para o conflito e, posteriormente, são utilizados para sustentar capacidades combativas e são motivadores para que os conhecidos "senhores de guerras" não queiram sair da situação de conflito aberto. (MÜNKLER, 2004, p. 8)

A interação causada pela globalização aliada com o avanço da tecnologia de comunicação possibilitou uma maior aproximação da comunidade internacional com os conflitos, não somente no que tange às elites internacionais, mas em relação ao público em geral que pelo noticiário informou-se sobre os diversos conflitos que estavam acontecendo ao redor do mundo e suas consequências, o que é chamado de "efeito CNN" 6 . O "efeito CNN" tem forte influencia sobre a opinião pública internacional, cuja mobilização exige respostas dos governos e ONGs para as emergências, gerando picos de solidariedade pelas questões

${ }^{6} \mathrm{O}$ "efeito CNN" refere-se ao crescente poder das cadeias televisivas, como a Cables News Network (CNN), na formação da agenda política internacional e sobre a opinião pública. (STROBEL, 1996) 
internacionais a todo o momento, enquanto decresce o interesse pela emergência anterior. $\mathrm{Na}$ resposta às novas emergências, os governos, em muitas circunstâncias, recorrem ao trabalho das ONGs, cuja relação será abordada posteriormente. O efeito $\mathrm{CNN}$ não é somente em prol da resposta às emergências, mas também pode ter o efeito contrário, caso a população acredite que o apoio do seu governo não está sendo eficiente ou que as suas tropas estão sofrendo represálias intensas demais, como foi o caso de mudança de apoio da opinião pública norte-americana depois de ver as represálias sofridas pela tropa norteamericana na Somália. (STROBEL, 1996)

O regionalismo começou a chamar atenção dos estudiosos depois do fim da Guerra Fria ao perceber-se que em várias regiões do mundo os conflitos espelhavam a situação da sua própria região. Ou seja, um fator precipitante comum gera conflitos violentos em diversas zonas vulneráveis, por exemplo, a região dos Grandes Lagos na África, cujas questões de identidade, conflito de secessão e movimentos de refugiados causaram conflitos em vários países, tais como República Democrática do Congo, Ruanda, Uganda, Burundi e outros, os quais eram zonas instáveis e de criação recente. (RAMSBOTHAM; WOODHOUSE: MIALL, 2009, p. 98)

Os efeitos regionais podem ser para fora ("spill-over", "contágios" e “difusão") e para dentro ("influência", "interferência" e "intervenção"). As guerras internas têm influência sobre a região através da disseminação de armas, perturbação econômica, ligações terroristas, refugiados e o transbordamento das questões para a política regional, quando os Estados vizinhos são levados para o conflito ou os "beligerantes" atravessam para os outros Estados. Em contrapartida, a instabilidade regional afeta a política interna dos Estados por meio de padrões de clientelismo, ações dos governos externos, movimentos transfroteiriços de pessoas e ideias, atividades de mercado negro, redes criminosas e a disseminação de armas de pequeno porte. Em alguns casos, o desafio para o governo em exercício pode ser inteiramente iniciado externamente, como quando a Rodésia, atual Zimbábue, formou a RENAMO em Moçambique depois de 1975. (pp. 9899)

Ao mesmo tempo, os arranjos de segurança regional e de integração regional podem contribuir para a contenção e limitação de conflitos internos. As mesmas ainda podem ser utilizadas como respostas aos conflitos complexos, 
desde o primeiro momento de cessar fogo e posteriormente na reconstrução do país e de sua sociedade. (p. 100)

\subsubsection{Estados Falidos}

A construção de Estados no mundo teve quatro ondas, como argumenta Chazan, sendo que todas foram decorrentes da queda de impérios. A primeira foi no século XIX com a independência da América do Sul, a segunda no pós Primeira Guerra Mundial localizada na Europa; a terceira foi na África e Ásia depois da Segunda Guerra Mundial e a quarta e última foram após o fim da União Soviética e localizaram-se na Ásia Central e na Europa Oriental. A maioria desses momentos associou-se com a criação abrupta de novos Estados, envolvendo conflitos de território e identidade. (CARMENT, 2003, p. 411) Robert Jackson apontou que as ex-colônias foram emancipadas internacionalmente e incumbidas dos mesmos direitos e responsabilidades externas dos demais Estados

juridicamente soberanos; no entanto, elas não foram autorizadas e habilitadas democraticamente e consequentemente não possuem as características institucionais dos Estados soberanos. (SMITH, 1990, p. 21) Em decorrência, os novos Estados independentes, ou os independentes da terceira e quarta onda, não foram preparados para assumir as responsabilidades e os direitos do Estado. Sendo assim, os seus líderes eram incapazes de formar um Estado de direito: com instituições fortes; participação e representação popular; inserido em um mundo globalizado; e interagindo com os demais Estados em pé de igualdade. Consequentemente, esses Estados estavam fadados ao fracasso.

Ao contrário das elites da Europa Ocidental e da América Latina, os líderes africanos, asiáticos e do leste europeu foram confrontados por três elementos que aumentaram a sua percepção de insegurança. $\mathrm{O}$ primeiro era as fronteiras que eram mais arbitrarias; o segundo é que suas sociedades possuíam uma composição geralmente mais diversificada; e o terceiro é que poucos líderes tinham experiência na construção de culturas inclusivas, cívicas e democráticas. (CARMENT, 2003, p. 411) Os problemas peculiares aos Estados africanos e do leste europeu levam a uma disfunção entre Estado e sociedade, cuja herança colonial impôs artificialmente ideias europeias de soberania territorial para uma multidão de grupos comunais, no princípio de "dividir para reinar", ou seja, os 
europeus tinham como objetivo dividir o território que eles dominavam com o maior número de grupos rivais possíveis, para assim conseguirem dominar com facilidade aquele território. (RAMSBOTHAM; WOODHOUSE: MIALL, 2009, p. 86)

Em decorrência, os Estados africanos foram expostos na sua colonização a diversos sistemas políticos em um sistema de Estado artificial. Essa fachada de soberania não podia ser sustentada sem apoio externo. No entanto, a maioria dos Estados ocidentais não previu que a onda de autodeterminação dos anos 60 seria seguida por colapsos nesses Estados. Os Estados ocidentais não prestaram atenção para o desenvolvimento de instituições de governança que poderiam apoiar a formação destes Estados. Consequentemente, a convergência de interesses e forças conseguida no momento da independência converteu-se em fragmentada por lealdades étnicas, fazendo com que o Estado se baseasse em autoridade pessoal e coerção, ou até mesmo em sistema totalitário. (CARMENT, 2003, p. 412)

Há de se ressaltar, contudo, que a integridade do Estado foi uma característica do cenário internacional durante a Guerra Fria, uma vez que, no período em que as armas nucleares impediram um confronto direto entre as duas superpotências, elas envolviam-se em guerras por procuração e apoiavam os seus aliados geopoliticamente estratégicos em regiões inseguras, fazendo com que os Estados africanos mantivessem o seu território, apesar dos conflitos de identidade interno. (p. 411)

O principio de autodeterminação presente na comunidade internacional, presentes nos fóruns de queixas, e interiorizado por diversos grupos minoritários, os quais se viam como excluídos durante o processo de construção do Estado contrapõem-se a lógica de construção estatal. Pois, a lógica presente na construção do Estado se baseia na união de seus cidadãos perante a uma história comum a qual identifica a todos como pertencentes ao mesmo povo e na dicotomia do "Eu" X "Outro", ou seja, na contraposição dos que estão dentro do Estado com os que são de fora. A tensão presente no Estado diante dessa oposição entre a lógica de construção do Estado e o principio da autodeterminação é insustentável enquanto não se tem instituições estabelecidas e reconhecidas pela sociedade no nível de resolução de conflitos e programas direcionados aos problemas das minorias. Em consequência da tensão presente no Estado e a incapacidade dele de conseguir 
lidar com ela faz com que a negação das minorias e a violência contra elas estejam presentes na maioria dos Estados que vão conseguir a sua independência no pós1945. (pp. 412-414)

Adentrando os aspectos do relacionamento Estado e sociedade percebe-se as principais características apresentadas pelos Estados falidos e como eles influenciam os conflitos estudados nesta dissertação. Os aspectos externos possuem grande influência para os Estados falidos alcançarem esta situação, mas é no relacionamento do Estado e da sociedade que podemos observar a principal característica para sua ocorrência.

O Estado quando criado incute-se de soberania no plano externo, a qual determina a não-interferência dos demais Estados do cenário internacional nas suas políticas e problemas internos e a sua autonomia e independência para relacionar-se no plano internacional. No entanto, ao mesmo tempo, ele assume a soberania em relação a sua população, ou seja, ele precisa prover as necessidades básicas da população. A soberania interna quebra-se quando o Estado não consegue cumprir esta função básica. A privação das necessidades humanas é uma das fontes basilares para o conflito social, pois normalmente o descontentamento com a privação das necessidades é expressa coletivamente. E, ao contrário dos interesses, as necessidades não são negociáveis, de modo que, se o conflito acontecer, é possível que seja intenso e, a partir de uma perspectiva tradicional, "irracional". Em particular, ressaltam-se as necessidades de segurança, desenvolvimento, acesso público e identidade (expressão cultural e religiosa). (AZAR, 1990, p. 9)

Visando o cumprimento de suas obrigações, o Estado foi dotado de autoridade $^{7}$ para governar e usar a força quando necessário para regular a sociedade, para proteger os cidadãos e para fornecer bens coletivos. Caso o estado não consiga prover estes bens coletivos, como foi dito anteriormente, os indivíduos e grupos de identidade ficam frustrados, causando um conflito social, mesmo que não-violento no princípio. Observa-se, então, que sociedades que passam por prolongado período de conflito social possuem, normalmente, governos incompetentes, paroquiais, frágeis e autoritários, os quais não conseguem satisfazer as necessidades humanas básicas. (MIALL;

\footnotetext{
7 Autoridade é compreendida nesta dissertação por direito de se fazer obedecer; influência e prestigio. (DICIONÀRIO AURÉLIO, 2012)
} 
RAMSBOTHAM; WOODHOUSE, 2009, pp. 86-87) Contudo, apesar de o Estado estar fraco nestas situações, ele continua sendo o principal ator no cenário internacional e deve ser considerado na mediação, até mesmo porque ele é o grande perpetuador da violência, como é o caso do tipo de conflito estudado nesta dissertação. (p. 100)

Quando o Estado se encontra nesta situação enfraquecida, ele não consegue suprir o que a teoria liberal determina que ele é, ou seja, perante a teoria liberal o Estado é um agregado de indivíduos encarregados de governar de forma eficaz e para agir como árbitro imparcial dos conflitos entre as partes constituintes, tratando todos os membros da comunidade política como cidadãos legalmente iguais. No entanto, não é isso que acontece empiricamente em muitas partes do mundo, particularmente nos Estados mais novos e menos estáveis, onde a autoridade política tende a ser monopolizada por grupo da identidade dominante ou uma coalizão de grupos hegemônicos dos que usam o Estado para maximizar os seus interesses à custa dos outros. Isso ocorre tanto através da mobilização de grupos de interesses e identidades pelas elites dominantes como através de políticas de exclusão das minorias. (p. 87)

A relação sociedade e Estado não influencia somente os aspectos internos do Estado, mas também a sua posição no cenário internacional. $\mathrm{O}$ alto nível de instabilidade interna limita a capacidade do Estado de agir como autoridade dentro da comunidade internacional, restringindo a sua capacidade de agir sobre a sociedade nacional com legitimidade. Sugere-se, então, que a legitimidade de um Estado esteja intimamente ligada às políticas étnicas que ele possui. (CARMENT, 2003, p. 415) A legitimidade, que sustenta a "força do Estado", pode ser dividida em vertical - consenso político entre governantes e governados sobre as "regras do jogo" institucionais - e horizontal - comunidade política inclusiva na qual todos os indivíduos e grupos têm igual acesso às decisões e atribuições. (RAMSBOTHAM; WOODHOUSE: MIALL, 2009, p. 100)

Os Estados em decadência estão em fases de transição sendo que neles as ideologias existentes não legitimam as posições de diversos atores sociais na estrutura hierárquica. Sob tais condições, a maioria dos estudiosos prevê como resultado o colapso da ordem social e política. A liderança não tem meios e credibilidade para manter a ordem interna ou repelir uma agressão externa. Além disso, a liderança não consegue suprir as necessidades básicas da população e 
conseguir apoio mínimo nacional. O Estado em colapso é quando ele perde a sua legitimidade, tem poucas instituições funcionando, oferece pouco ou nenhum serviço público aos seus constituintes e é incapaz de conter a fragmentação. (CARMENT, 2003, p. 413)

A fragmentação da sociedade inicia-se pelo Estado central ao deteriorar-se. A deterioração do Estado ocorre segundo uma progressão de três etapas. $\mathrm{Na}$ primeira, as instituições não fornecem serviços adequados à população. $\mathrm{Na}$

segunda, as instituições já enfraquecidas são ainda mais corroídas pela canalização da competição étnica, social e ideológica. Na terceira, os efeitos cumulativos da pobreza, superpopulação em êxito rural e forte urbanização, bem como degradação ambiental, sobrecarregam o Estado fraco levando a um ponto de colapso. (p. 413) Essa fragmentação social que se inicia a partir desses processos é um dos fatores que vai gerar a fragmentação dos grupos armados nos conflitos complexos.

Devido à fraqueza do Estado e a sua baixa legitimidade, os tomadores de decisão começam a confiar mais extensivamente nas formas coercitivas de gestão das tensões internas e concentram o poder nas mãos de poucos, potencializando o problema em relação aos grupos étnicos, causando problemas recorrentes de governabilidade para aqueles no poder. (pp. 413-414)

As políticas de exclusão foram uma fonte importante de erosão da legitimidade do Estado, como mostram as políticas de exclusão utilizadas por Tutsi e Hutus em Ruanda e Burundi. Em decorrência, o padrão hierárquico de autoridade central quebra levando à descentralização étnica e regional informal, que formam organizações políticas e econômicas, resultando no conflito entre um grupo étnico dominante das instituições políticas e os esforços de reequilíbrio por grupos minoritários para tirar o controle do centro de poder. (pp. 414-415)

As políticas de exclusão difundidas por indivíduos e grupos dominantes limitam o acesso de outros grupos, precipitando uma crise de legitimidade, como já foi dito. A legitimidade do Estado está intimamente relacionada às políticas étnicas que o Estado possui. (RAMSBOTHAM; WOODHOUSE: MIALL, 2009, pp. 87-88)

\subsubsection{Características dos conflitos complexos}


A fragilidade do Estado, que não consegue prover as necessidades básicas da população, os regimes autoritários, as políticas de exclusão e, em consequência, a crise de legitimidade e soberania sofridas por ele levaram à perda do monopólio do uso da força pelo Estado e a sua fragmentação. Tal fato ocorre porque a população começa a direcionar a sua legitimidade aos grupos de identidade, tribais, religiosos ou demais grupos particulares cujo reconhecimento perante eles a atraia. Além disso, os grupos minoritários, os quais se sentem excluídos pelo poder central, não conseguindo manifestar o seu descontentamento, acabam por buscar a luta armada; alcançando, assim, a situação de conflito complexo, o qual apresenta como características: a multiplicidade de forças de combate, as quais englobam unidades privadas e públicas, estatais e não estatais, ou ainda uma mistura entre elas. (BUTLER, 2009, p. 58)

Em decorrência disso, os conflitos complexos diferenciam-se consideravelmente dos conflitos tradicionais, pois o ataque a civis, nos conflitos complexos, é destacado como estratégia militar, enquanto nos conflitos tradicionais era evitado que os civis fossem atingidos pela guerra e era priorizado que esta ocorresse distante das áreas civis. O deslocamento da população, massacres sistemáticos, desrespeitos aos direitos humanos e atividades criminais são correntemente utilizados como estratégias de guerra pelo governo e pelos "rebeldes". Consequentemente, a separação entre civis e militares, que foi defendida pela Convenção de Genebra e seus Protocolos adicionais perde o sentido no tipo de conflito estudado e toda a população é atingida diretamente ou indiretamente pelo conflito. Quando o Estado começa a atacar civis, perde ainda mais a sua legitimidade perante a população, que durante o processo já está enfraquecida, o mesmo acontece em relação a comunidade internacional, que começa a questionar o ataque à população a qual o Estado deveria estar protegendo. (p. 60)

A estratégia de guerra utilizada nos conflitos complexos baseia-se na dicotomia excluído e incluído. A dicotomia presente já estava instalada na sociedade antes do inicio armado do conflito e foi um dos fatores que o levaram a tornar-se armado. A sociedade já era baseada na distinção psicológica de dentro e fora realizada a partir de grupos étnicos, religiosos, linguísticos ou outro tipo de grupo. Essa distinção era utilizada para propagar o medo em relação ao outro e 
justificar os ataques violentos direcionados aos demais grupos. A população civil é a que mais sofre neste tipo de conflito: deve-se considerar que as mortes em conflito complexo são $80 \%$ de civis contra somente $20 \%$ de combatentes ativos no conflito. (MÜNKLER, 2004, p. 14) Em decorrência de tais fatos, é necessário que a mediação esteja preocupada em quebrar a dicotomia e interagir com os diferentes grupos que dividem a sociedade. (ver LEDERACH, 2009 e o tópico 2.2.1.2.)

A guerra é sustentada pela propagação do medo, da insegurança e na perpetuação do ódio ao outro, os quais se baseiam na dicotomia excluído/incluído, visto que, mesmo quando as tensões religiosas, étnicas e de outros grupos particulares não são as causas do conflito, como na maioria das vezes acontece, as tensões são formas da elite reforçar o conflito e conseguir legitimar os seus ataques contra a população. (p. 6) Considerando isto, é necessário que a violência atinja a maior parte possível da população, para conseguir estabelecer uma cumplicidade entre os considerados como "eu" contra o "outro", aprofundando as diferenças. (KALDOR, 2001) Consequentemente, a mediação não pode se limitar aos governantes, como é feito tradicionalmente, ou somente incluindo os líderes dos grupos armados. A mediação precisa envolver toda a sociedade em um processo longo e trabalhoso de mudança de perspectiva.

A manipulação da população por parte da elite utiliza-se da estratégia de desrespeito aos direitos humanos e na dicotomia excluído/ incluído, o que é feito com o objetivo de mobilizar os combatentes na população e motivar o conflito, pois os grupos fazem o recrutamento na população e precisam que ela os apóie no combate ao "outro". (BUTLER, 2009, 59) A sociedade encontra-se fragmentada, dividida em sub-grupos, em decorrência é necessário que o trabalho de mediação seja realizado desde o nível basilar da sociedade, o que não é possível para Estados, organizações internacionais e regionais devido ao seu engessamento burocrático $^{8}$ e a necessidade de demonstrar resultados ao público, impedindo que eles envolvam-se em trabalho de longo prazo. (ver LEDERACH, 2009)

A população não sofre somente com o ataque direto nos conflitos complexos, o ataque dos grupos armados à estrutura do Estado e a utilização destes para perpetuar o conflito ou para ganhos próprios. A população civil sofre

\footnotetext{
${ }^{8}$ Burocracia é compreendido como sendo morosidade e complicação no desemepnho do serviço público. (DISCIONÁRIO AURÉLIO)
} 
com as causas indiretas do conflito, tais como fome, doenças, falta de água, deslocamento interno, entre outros. As mortes causadas indiretamente pelo conflito são maiores do que as causadas diretamente, pois uma das características presentes no conflito complexo é a associação da violência militar à escravidão e à epidemia. (MÜKLER, 2004, p. 15)

A escravidão nos conflitos complexos está intimamente ligada à sexualização do conflito e ao estado de pânico que os grupos querem deixar a população. A escravidão tem duas facetas divididas claramente por gênero. As meninas tornam-se escravas sexuais utilizadas tanto como prêmio para os soldados como para os "lordes/senhores da guerra". Enquanto os meninos são utilizados como soldados no front de batalha, o que é especialmente devastador para a sociedade, visto que grande parte das mulheres jovens da sociedade sofreu com o estigma do rapto e os homens precisam ser recuperados após o período como soldados. (p. 20) Consequentemente, a mediação precisa trabalhar com um país destruído não somente no psicológico da população, mas também estruturalmente sem condições para desenvolver-se. O trabalho psicológico com a população é feito com mais eficiência pelas ONGs, como será analisado posteriormente. (ver CHIGAS, 2007, pp. 563-566)

Os grupos armados encontrados nos conflitos complexos são muito diferentes do que é compreendido como exército nacional tradicional. Os conflitos complexos são caracterizados pela multiplicidade de formas de combate, os quais englobam unidades públicas e privadas, estatais e não-estatais ou ainda pode ser uma mistura desses tipos. Münkler coloca que a maioria desses "exércitos" não é equipado e formado de modo tradicional. A maioria dos seus líderes são chefes de clãs, tribais ou milícias que recrutam os seus seguidores. Os armamentos utilizados por estes exércitos/guerrilheiros não são adquiridos pelas vias legais e não são os que tradicionalmente são encontrados em conflitos, são constantemente armas leves ${ }^{9}$. (p. 15)

A privatização da guerra é uma das principais características dos conflitos complexos, o que tem como resultado a contratação de mercenários e empresas de segurança por parte dos Estados ou de outros grupos. Isto está intimamente relacionado à economia de guerra e ao fracasso do Estado, o qual não possui mais

\footnotetext{
${ }^{9}$ Armas leves ou de pequeno porte são aquelas que podem ser transportadas poruma ou duas pessoas e possuem calibre menor do que $100 \mathrm{~mm}$, como exemplo são as pistolas e metralhadoras.
} 
o monopólio do uso da força e não consegue manter a ordem dentro do Estado, precisando até mesmo privatizar a segurança. (p. 21)

A economia de guerra tem como principais atores os "senhores da guerra" e empresários transnacionais, os quais se aproveitam da falta de estatização da guerra. Eles conseguem controlar e são capazes de manter grandes áreas, aproveitando-se do colapso do Estado para ganhos próprios, conseguindo atribuir para si o poder do Estado. Obviamente, não para impulsionarem na construção do Estado, mas para reunirem vantagens adicionais que vêm do reconhecimento internacional, o qual traz suporte econômico, acesso ao mercado internacional e a possibilidade de transferir os seus ganhos ilícitos e protegê-los dos "senhores da guerra" concorrentes. Nesses casos, em que os "senhores da guerra" atribuem a si o poder do Estado, não é com o objetivo de se responsabilizarem da construção do Estado, o que pode aparecer em algum momento. É somente outra maneira de continuar usurpando. (p. 17)

Os "senhores da guerra" são encontrados sempre em regiões onde a proteção do Estado não se encontra e onde produtores e mercadorias são associadas com a aquisição violenta de bens, serviços e títulos legais, o que sempre ocorre quando a estrutura do Estado está definitivamente quebrada. (p. 17)

Os "senhores da guerra" e os grupos que os acompanham começam a perceber a guerra como um modo de vida, por meio do qual conseguem alcançar poder e a fortuna. A fortuna deles é feita em termos imediatos com o roubo e a pilhagem; em médio prazo com o trabalho escravo; e em longo termo, constroem economias paralelas, nas quais a violência e o intercâmbio são inseparáveis para sustentar todo o sistema econômico informal. Por isso, os beligerantes que controlam o sistema e os grupos ligados a eles não possuem incentivos para sair do conflito e, para defender esses interesses, o objetivo destes grupos na guerra não é mais a batalha decisiva, mas sim o massacre. (p. 14)

A violência presente nos conflitos complexos é utilizada para intimidar a população civil desarmada. A economia de pilhagem e roubos cria um ambiente de medo. Os soldados não precisam mais respeitar as leis da guerra, as quais foram estabelecidas pela Convenção de Genebra e os seus Protocolos adicionais e demais tratados internacionais e nem se preocuparem com a punição, pois estas não são mais presentes e a sexualização da violência produz fenômenos tais como orgias diárias ou verdadeiras estratégias de estupro, além da utilização cada vez 
mais comum da mutilação da vítima e a exibição de suas partes do corpo como troféus. (p. 14)

Em contrapartida, alguns grupos utilizam-se da violência somente para se preservar fisicamente. Hartmut Diessenbacher propôs o termo "overpopulation warrior" para descrever tais indivíduos, tornando claro que eles ameaçam usar a violência não para adquirir bens de luxo e símbolos de status, mas para garantir a sua sobrevivência. (pp. 17-18)

Os conflitos complexos trazem novos desafios para a mediação internacional, pois a presença de novos atores no conflito - os quais, na sua maioria, são ilegítimos e desrespeitam os direitos humanos e internacionais - a fragmentação do Estado, a diversidade de atores, a incapacidade de determinar o início e fim do conflito, a ilegitimidade do Estado perante a sua população, a incapacidade do Estado em implementar qualquer medida no seu território, o enfraquecimento do Estado, o envolvimento direto ou indireto de toda a população no conflito e a destruição dos recursos do Estado e de sua estrutura fazem com que a mediação tradicional seja completamente inadequada para a resolução do conflito e que os atores tradicionais da mediação não consigam ou não queiram lidar com o conflito. Consequentemente, é necessário se pensar em um novo tipo de mediação, mais ampla e flexível e em novos atores para compor o quadro de mediadores.

\subsubsection{Os conflitos complexos e a mediação internacional}

A mediação precisa se adaptar à nova natureza do conflito. A mediação tradicional era realizada com as partes reconhecidas do conflito, principalmente governos, pois ela era voltada à resolução de conflito intraestatal. (ver KLEIBOER, 1996, p. 381) Ou seja, o mediador não precisava negociar com as partes consideradas ilegítimas do conflito, por exemplo, guerrilheiros e rebeldes, os quais são os principais atores nos conflitos complexos, detentores de força armada e parte do território, sendo assim eles são impossíveis de serem desconsiderados no momento da mediação. (MÜNKLER, 2004, p. 58) O objetivo também muda em relação à mediação tradicional, enquanto esta queria parar as hostilidades e assinar o Acordo de Paz, desconsiderando as reais causas do 
conflito. Nos conflitos complexos, este mesmo objetivo só fará com que o acordo seja desrespeitado e as hostilidades se reiniciem.

$\mathrm{O}$ conflito tradicional também possui um momento de maturação ${ }^{10}$ mais claramente determinado, pois, em um determinado momento, os Estados desejariam sair do conflito devido ao desgaste causado por este. No entanto, a mesma lógica não se aplica a conflitos complexos, pois os "senhores da guerra" têm ganhos com a permanência do conflito e não têm motivação para sair dele; pelo contrário, a manutenção do conflito faz com que eles mantenham o seu status e os seus ganhos econômicos. (RAMSBOTHAM; WOODHOUSE; MIALL, 2009, pp. 18-23) Nesse sentido é importante que a mediação estudada nesta dissertação considere mais fortemente as questões internas do conflito, não desconsiderando as suas interferências e consequências internacionais. No entanto, a mediação envolve-se mais intensamente com as partes em conflito, as suas relações e reivindicações. Isto não significa, entretanto, que esta dissertação está desconsiderando fatores externos dos conflitos, tais como fluxo de dinheiro, contrabando de armas e recursos naturais que são na maioria de vezes controlados pelos "senhores da guerra" e de onde eles retiram o financiamento externo para manter o seu poder.

O mediador tradicional lida com as partes em conflito no nível governamental, utilizando-se do poder militar e econômico para alcançar o acordo, consequentemente os mediadores mais indicados eram Estados - de porte médio ou alto - ou organizações internacionais e regionais que possuíssem poder militar e econômico suficientes para conseguirem cumprir esta missão. (pp. 1823) Em contrapartida, nos conflitos complexos, a mediação precisa atuar dentro do contexto do conflito, devido à fragmentação do poder e da sociedade, com o terror propagado, os direitos humanos desrespeitados, a falta de legitimidade do Estado, a qual se fragmenta em diversos grupos, e o envolvimento de toda a sociedade.

\footnotetext{
${ }^{10} \mathrm{O}$ conflito possui uma linha de tempo que pode ser divida em diversas fases distinguíveis e existem momentos em que ele está mais propício para que a mediação funcione de forma satisfatória, chamado de momento maduro do conflito. A maturação do conflito ocorre quando o conflito já está acontecendo há um período de tempo e os esforços dos indivíduos ou dos atores envolvidos atingem um impasse, chegando assim a uma situação em que os atores não estão mais dispostos a arcar com custos adicionais ou escaladas do conflito e ambas as partes estão prontas para iniciar o processo de diálogo de forma direta ou indireta. (Bercovitch, 1984)
} 
Nas circunstâncias apresentadas, a mediação precisa envolver-se desde o nível basilar da sociedade, ou seja, a mediação precisa ser realizada desde o nível local até os líderes dos grupos armados mais significativos e o governo. Principalmente, ao considerar sociedades divididas em clãs, tribos e com organização social fraca, como são os casos de conflitos que ocorrem em Estados fracos. Além disso, o mediador deve ter a capacidade de interagir com esses diferentes níveis. (ver LEDERACH, 2009) Posteriormente, serão analisados os diferentes tipos de mediação e de mediador presentes na literatura de resolução de conflito, para desta forma ser possível ponderar qual tipo melhor se adapta às características do conflito aqui estudado. Porém, obviamente, a mediação precisará englobar todos os níveis da sociedade, ser flexível, adaptável e responder rapidamente às necessidades apresentadas, devido à natureza instável das partes.

O conflito tradicional inter-estatal era separado da paz por atos legais. A Declaração de Guerra e o Acordo de Paz marcavam o início e o fim do conflito, não tendo, assim, estágios intermediários entre a paz e a guerra. Nos conflitos complexos, esta definição é complexa; raramente, é possível determinar quando o cessar fogo inicia-se e quando o confronto recomeça. (MÜNKLER, 2004, p. 13) A incapacidade de determinar quando se inicia e termina o confronto é um dos desafios que a mediação de conflitos complexos enfrenta. Na situação apresentada, não é possível considerar que a assinatura do cessar fogo ou do Acordo de Paz vai determinar o fim das hostilidades, mesmo que estes sejam assinados e corroborados por todos os participantes do conflito.

A diversidade de atores em conflito faz com que a mediação precise interagir com diferentes atores ao mesmo tempo, sendo que nem todos serão considerados legítimos internacionalmente, devido aos desrespeitos aos direitos humanos e a ataques maciços à população civil desarmada. Considerando a necessidade de interação com partes ilegítimas, durante a mediação, não se pode deixar de considerar o alto custo político que envolve esta ação e a talvez incapacidade dos Estados, organizações internacionais e regionais de realizarem a mediação. (ver MITCHELL, 1992, p. 277)

A fluidez do poder é um agravante nas dificuldades da mediação, pois, às vezes, o líder de uma facção pode negociar com pouca ou nenhuma autoridade, sendo que tudo que foi acordado pode ser ineficaz. Se o poder, em sistemas 
políticos estabelecidos pode ser considerado fluido em determinados momentos, em Estados em situação de conflito complexo e com a presença de "senhores da guerra" é impossível determinar quando o poder vai mudar de mão. A mediação pressupõe que os lideres das facções se sentem à mesa de negociação com autoridade para garantir os termos do acordo. Essa suposição é quase impossível de ser feita em conflitos complexos. (NATSIOS, 2007, p. 341) A fluidez do poder faz com a mediação tenha que ser mais ágil e flexível, pois quando o líder da facção presente nas negociações não possuir mais autoridade para garantir os termos do acordo, ele deve ser mudado ou acrescenta-se outro líder que tenha essa autoridade. Por isso, é necessário que o mediador não tenha um aparato burocrático complexo e conheça profundamente o conflito.

Nas circunstâncias apresentadas, os conflitos complexos são percebidos como doenças, sobre as quais é fundamental a investigação das causas primárias e não somente o tratamento dos sintomas. Pois, somente é possível curar a doença descobrindo as suas reais causas e assim é plausível construir um Estado reorganizado com instituições fortes. (DEBRIX, 1999, p. 196) No contexto, a mediação mais flexível e capaz de lidar com vários níveis da sociedade envolvidos no conflito conseguindo assim aprofundar-se nas suas reais questões e realizar um processo de cura. É necessário que a transformação completa do conflito aconteça, mudando-o para o campo político e não-violento. As ONGs nessas circunstâncias podem trabalhar melhor, já que elas preocupam-se em resolver o conflito como um todo e não somente com a assinatura do acordo de paz, o qual é uma consequência do longo trabalho feito pelas ONGs na sociedade em conflito. (ver LANZ; SGUAITAMATTI; SIEGFRIED, 2009, pp. 6-7)

De acordo com as circunstâncias apresentadas percebe-se que a mediação tradicional só está preparada para atuar em conflitos inter-estatais, o qual permite a implementação dos acordos de paz e a divisão entre privado e público, interno e externo, civilizado e bárbaro é definida e clara.

\subsection{A mediação internacional}

A mediação internacional é uma das resoluções pacíficas de conflitos considerada pela Organização das Nações Unidas. O papel do mediador no 
conflito é como a terceira parte interveniente de forma ativa, podendo propor soluções para a resolução do conflito.

Com as mudanças no conflito, que foram analisados anteriormente neste capítulo, a mediação internacional precisou adaptar-se. Atualmente, a mediação precisa englobar todo o conflito, não podendo se concentrar nos líderes principais do governo e dos "rebeldes". Até mesmo porque as forças em conflito são mais dinâmicas e diversificadas do que nos conflito intra-estatais.

Nesta seção serão debatidas as características da mediação e suas mudanças no pós-Guerra Fria com a entrada de novos atores e mudança no seu perfil. Pois, anteriormente os líderes dos "rebeldes" e do governo tinham legitimidade e autoridade para implementar o acordo feito por eles dentro da sociedade em conflito; atualmente esta legitimidade e autoridade é altamente fragmentada e fluida.

\subsubsection{Definições}

A solução pacífica de controvérsias é considerada pelas Nações Unidas, em sua carta de criação, como o modo prioritário de resolução de conflito ${ }^{11}$ por parte dos seus membros, ou seja, os membros das Nações Unidas devem esgotar todas as medidas pacíficas antes de recorrer ao uso da força para solucionar um conflito. $^{12}$

A Carta das Nações Unidas define os meios pacíficos no seu artigo 33(1): "negociação, inquérito, mediação, conciliação, arbitragem, solução judicial, recurso a entidades ou acordos regionais, ou a qualquer outro meio pacífico à sua escolha." (CARTA DAS NAÇÔES UNIDAS, 1945) Cada uma das soluções pacífica possui peculiaridades, as quais devem ser consideradas no processo de decisão do mais apropriado entre eles para a solução do conflito.

A solução de litígios internacionais é classificada em três categorias: diplomático (negociações diplomáticas bilaterais ou multilaterais, serviços amistosos, mediação e bons costumes); políticos (soluções dadas pelas

${ }^{11}$ O Centre for Study of Civil War (CSCW) do International Peace Research Institute, Oslo (PRIO) conceitua o conflito armado como: "prolonged combat between the military forces of two or more governments, or of one government and at least one organized armed group" (BUTTLER, 2009, p. 48)

12 Artigo 2(3) da Carta das Nações Unidas: "Todos os Membros deverão resolver suas controvérsias internacionais por meios pacíficos, de modo que não sejam ameaçadas a paz, a segurança e a justiça internacionais." 
organizações internacionais); e jurídico (comissões de inquéritos, conciliação, arbitragem e solução jurídica. Considerando que somente as decisões provenientes do modo jurídico, com exceção das decisões provenientes do Conselho de Segurança e das baseadas no Capítulo Sete da Carta das Nações Unidas são vinculantes. (MELLO, 1997, p. 1344)

A negociação internacional é entendida em seu conceito restrito, nesta dissertação, ou seja, limita-se às negociações realizadas entre as partes interessadas sem a intervenção da terceira parte, diferenciando-se da mediação e dos bons ofícios. No bom ofício, a terceira parte intervém com o objetivo de aplanar e abrir a via de negociação entre as partes interessadas ou reatar negociações que foram interrompidas. (p. 1346) A mediação internacional consiste na intervenção da terceira parte para ajudar as partes a atingir a resolução do conflito sem utilização da força ou parando o uso da força. (KLEIBOER, 1996, p.361) O papel do mediador é mais ativo do que da terceira parte nos bons-ofícios, participando das reuniões ativamente e regularmente e sugerindo ou tomando atitudes com o fim de solucionar pacificamente o conflito.

A mediação inicia-se quando a terceira parte é aceita pelas partes em conflito, sendo escolhida em comum acordo, podendo ela oferecer-se para a mediação ou ser convidada por ela. Caso ocorra a recusa do mediador, o ato não é encarando com animosidade. Apesar da mediação ser facultativa, algumas convenções internacionais proíbem a guerra antes da utilização da mediação, tal como o Ato Geral de Berlim. (MELLO, 1997, p. 1347)

A mediação possui o objetivo de levar as partes em conflito a uma solução aceitável para ambas as partes e coerente com os desejos e interesses da terceira parte. A mediação é definida como uma negociação com a intervenção da terceira parte, a qual objetiva ajudar as partes a atingirem a solução, visto que elas não conseguiam alcançar sozinhas. As partem devem cooperar diplomaticamente com o interventor para conseguir alcançar os seus objetivos. (ZARTMAN; TOUVAL, 2007, p. 438)

A conciliação fundamenta-se em um tratado e consiste no exame do litígio por um órgão de confiança das partes, contudo, não envolve a participação direta da terceira parte no processo de negociação, propondo uma solução baseada em concessões e recíprocas, a qual pode ser aceita ou rejeitada. Observa-se que a conciliação poder ser compreendida como uma mediação "institucionalizada", a 
qual se sujeitam às regras de procedimento (regras da Comissão de Conciliação). Ressaltando que apesar de muitos tratados designarem a mesma Comissão de Conciliação para as funções de conciliação e investigação, as funções não podem ser confundidas, pois referem-se a duas funções distintas. (MELLO, 1997, pp. 1350-1351) A distinção entre bons-ofícios, mediação e conciliação é feita restritamente no campo acadêmico, pois em termos práticos elas confundem-se. (p. 1353)

A solução jurídica e a arbitragem distinguem-se em seus aspectos formais, pois o tribunal arbitral é constituído pelas partes litigantes objetivando resolver o conflito, enquanto o tribunal judiciário é pré-existente ao litígio, subsiste à sua solução e é composto por membros não escolhidos pelas partes. As decisões resultantes das soluções arbitrais e jurídicas possuem caráter vinculante, ou seja, são obrigatórias, baseadas no Direito Internacional, e o órgão, do qual emana a decisão, tem que ser imparcial. (p. 1353)

\subsubsection{Histórico da mediação internacional}

A partir do final da Primeira Guerra Mundial, desenvolveu-se o pensamento sobre a "ciência" da paz, a qual funcionaria como a base para evitar novas guerras. Segundo Peter van den Dyngen, as primeiras iniciativas foram realizadas na França, Alemanha, Holanda, Estados Unidos, Suíça, Tchecoslováquia e outros países. Todavia, as iniciativas eram de caráter isolados e individuais. Somente após a Segunda Guerra Mundial e a ameaça da bomba nuclear, que uma nova urgência pela "ciência" da paz. apresentou-se. (RAMSBOTHAM; WOODHOUSE; MIALL, 2009, p. 52)

Todavia, durante o processo de construção da "ciência" da paz, os estudiosos pioneiros da resolução pacífica de conflitos contribuíram consideravelmente para a disciplina, com a integração da psicologia, dos estudos internacionais e da política. A interdisciplinaridade presente influenciou os estudos pós-1945. Tendo, como exemplos, os estudos psicológicos do grupo social em conflito, conduzidos por Kurt Lewis em 1949, os quais influenciaram os futuros estudos de resolução de conflito. (p. 54)

Nos anos de 1945 e 1965, foram criados os primeiros institutos especializados em resolução de conflitos e para o estudo da paz, abrindo o 
processo de resolução de conflito na academia. (p. 54) Sendo, no auge da Guerra Fria, nas décadas de 50 e 60, que a resolução de conflitos começou a ser considerada em decorrência do iminente conflito entre as duas potências e a possível ameaça à humanidade, como a bomba nuclear. (p. 7)

$\mathrm{Na}$ década de 80, o campo da resolução de conflitos engaja-se na real solução do conflito, como o caso do Apartheid na África do Sul e do processo de paz no Oriente Médio. Nesse período, ocorre, ainda, a mudança na visão das agências humanitárias e dos seus trabalhadores, devido à amplitude do conflito na África e no Sudeste Asiático. As agências humanitárias perceberam, então, a necessidade de incluir outros campos ligados ao conflito e a sua resolução nas suas políticas. (p. 8)

Como consequência do fim da Guerra Fria, o campo de resolução de conflito necessitou adaptar-se à nova situação internacional e os conflitos, em decorrência, às práticas oficiais e não oficiais. Isto ocorreu, uma vez que a melhora nas relações das Grandes Potências resultou no prolongamento dos conflitos na África Austral, América Central, Oriente Médio e Ásia Oriental, os quais tinham sido sustentados ideologicamente e militarmente pela Guerra Fria. (p. 8)

\subsubsection{Tipos de mediação}

A mediação internacional é um processo complexo e muitos atores não concordam sobre como ela deve ser realizada objetivando minimizar as consequências negativas e maximizar os benefícios; todavia, Louis Kresberg consegue reunir o que considera como premissas gerais da mediação internacional, as quais possuem uma grande base de concordância entre os autores deste tema, sendo que três delas merecem especial atenção. (KRIESBERG, 2007, pp. 466-467)

A primeira premissa se refere à inevitabilidade do conflito ${ }^{13}$ na vida social. Ao contrário do que muitos acreditam, o conflito não possui somente aspectos negativos, mas, muitas vezes, serve para avançar e sustentar os valores humanos, incluindo a segurança, liberdade e bem-estar econômico. A questão é como evitar

\footnotetext{
${ }^{13} \mathrm{O}$ conflito existe quando no mínimo dois atores, se esforçam para adquirir, no mesmo momento, um conjunto de recursos escasso, os quais não precisam ser materiais, podendo ele ser armado ou não. (WALLENSTEEN, p. 16)
} 
que esses conflitos se transformem em confrontos violentos e consequentemente destruam os próprios valores que estão perseguindo. (p. 467) O conflito pode contribuir positivamente para a sociedade e ele é dinâmico, ou seja, o conflito pode ser transformado, mas não eliminado. (WALLENSTEEN, 2002, p. 39)

O conflito armado é somente uma das categorias do fenômeno geral dos conflitos sociais e ele decorre, normalmente, de um conflito não armado e possui características especificas. (p. 61) Desta forma, a resolução de conflito se empenha para que as partes enfrentem conjuntamente a sua incompatibilidade e encontrem maneiras de viver com elas ou dissolvê-las. Considerando isto, a resolução de conflitos é mais ambiciosa do que a gestão de conflitos, a qual se concentra no aspecto armado do conflito, ou seja, levar a luta a um fim, limitando a propagação do conflito violento e, consequentemente, contê-lo. (p. 53)

A segunda premissa consiste em que os conflitos são um tipo de interação social, na qual cada parte afeta o outro. Cada lado é capaz de afetar o adversário utilizando a sua própria conduta. Além disso, um das partes pode reforçar a sua posição de diversas formas, inclusive prejudicando e destruindo o adversário. (KRIESBERG, 2007, p. 467) O prejuízo a posição e a ideologia da outra parte é comumente utilizado nos conflitos complexos; utilizando o ataque e a disseminação do ódio ao "outro" por meio de desrespeito aos direitos humanos, a destruição da subsistência da outra parte, tornando o outro não somente uma das partes em combate, mas também inimigo de toda ou parte considerável da sociedade. (ver BUTLER, 2009, p. 59)

Obviamente, o relacionamento entre essas partes nunca é simétrico, mas desigual. (p. 467) Sendo assim, muitos analistas defendem que é necessário para o sucesso da mediação a existência de um equilíbrio de poder entre as partes. Esse equilíbrio pode ser conseguido com a utilização de advogados ou até mesmo o próprio mediador pode utilizar uma estratégia que consiga alcançar esse objetivo durante o processo. $\mathrm{O}$ equilíbrio é importante, pois a parte mais forte pode não desejar a mediação, que a impediria de alcançar os ganhos totais que o conflito permite. Isto pode ocorrer no inicio ou até mesmo durante a mediação, o que impediria a resolução satisfatória do conflito e a permanência ou existência da própria mediação. (p. 468)

A terceira premissa é que perante as etapas destrutivas e construtivas do conflito a compreensão e as forças políticas que moldam a trajetória são cruciais 
para a resolução de conflito. Um conflito deve ser cuidadosamente analisado para as políticas especificamente escolhidas pelas partes e intermediários sejam eficazes. (p. 467) Nesse sentido percebe-se a importância de identificar as incompatibilidades que marcam as disputas entre as partes e condições as quais levariam o conflito ao seu fim com êxito. No conflito civil, quando as partes não conseguem resolver as suas incompatibilidades, é mais provável que o conflito se torne prolongado do que termine com a vitória de uma delas. (WALLENSTEEN, 2002, p. 136) Consequentemente, a resolução de conflito deve identificar as necessidades e incluir formas de respondê-las englobando as necessidades psicológicas, econômicas e relacionais. (p. 39-40) Nessa situação é fundamental conhecer o conflito, o que as ONGs têm a capacidade de fazer por duas situações: primeiramente, elas desenvolvem trabalhos de estudo sobre os conflitos existentes no mundo; em segundo lugar, as ONGs estão diretamente presentes no conflito ou conseguem informações devido a sua rede de comunicação, cujo compartilhamento de informações é realizado entre as ONGs envolvidas ou que pretendem se envolver no conflito. Podemos perceber assim que as ONGs são instituições muito bem informadas sobre os conflitos que ocorrem no sistema internacional e possuem completa capacidade de analisá-los. (ver AALL, 1996, p. 19; LANZ; SGUAITAMATTI; SIEGFRIED, 2009, p. 5)

Como já foi dito, a mediação internacional é uma ação complexa que pode ser realizada de diversas maneiras. Kleiboer nos apresenta quatro perspectivas para a mediação. A primeira é chamada de "Power brokerage" e é a mais comumente observada na mediação. Ela possui uma dinâmica que pode ser descrita em termos de uma teoria explicativa e preditiva. Essa perspectiva se encaixa perfeitamente no mundo dos teóricos neo-realistas, os quais vêm o conflito como sendo endêmico no sistema internacional anárquico. Os defensores dessa perspectiva acreditam que o mediador deve ser neutro em relação às partes em conflito e ter considerável influência sobre elas para conseguirem fazer com que as partes aceitem medidas e propostas de solução a que talvez não tenham aderido. (KLEIBOER, 1996, p.380) Quando analisamos as premissas dessa perspectiva, pode-se observar que na realidade ela só está preocupada em conter o conflito e fazer com que ele deixe de ser armado, pois não é possível concebermos uma resolução real do conflito perante uma solução em que as partes não concordem realmente. Somente é possível a real resolução do conflito complexo 
quando as incompatibilidades que levaram ao conflito forem discutidas e possuírem soluções concretas para elas e principalmente que as partes entendam que vão ganhar mais buscando a solução política e não violenta para as suas disputas, ou seja, quando ocorrer uma real transformação do conflito.

A segunda perspectiva é considerada como "political problem solving", na qual a resolução de litígios é baseada em uma ontologia fundamentada em diferentes conflitos internacionais e epistemologia de análise de conflito. Ainda que compartilhe a perspectiva realista de que o conflito deve ser evitado ou controlado, esta perspectiva se inspira na psicologia política. Eles não pretendem alcançar uma única e geral teoria sobre o conflito internacional, mas defendem o desenvolvimento de contingentes, descrição sistemática e uma compreensão multi-nível da dinâmica do conflito particular em cada caso. (p. 382) Como já havíamos observado, o conflito é normal na sociedade e até mesmo a ajuda a se desenvolver, afirmar e mudar os seus valores, sendo assim, é impossível evitá-lo completamente. O que é necessário é saber lidar com ele para não torná-lo violento e é isto que deve ser implementado em sociedades que estão saindo do conflito: modos de se resolverem de forma pacífica. (WALLESNTEEN, 2002, p.61)

A terceira perspectiva é a "reestablishing social relationship" que parte da mesma antologia e epistemologia das perspectivas anteriores, porém se difere por ver os conflitos internacionais como oportunidades para a mudança social. Essa visão corresponde à perspectiva da Teoria Critica, particularmente da abordagem de Burton quanto às necessidades humanas sobre a política internacional. Para essa perspectiva os conflitos internacionais estariam enraizados entre as relações e estruturas sociais e a combinação das necessidades, perspectivas e disposições dos diferentes atores seriam altamente contingentes. (KLEIBOER, 1996, pp. 382-383) A teoria defende que os conflitos internacionais não são um fim em si mesmo, devem ser direcionados para "a construção de uma política orientada para o desenvolvimento racional de consensos entre os seres humanos, um regresso ao clássico entendimento da política voltada para o desenvolvimento de uma política emancipatória, na qual os indivíduos são sujeitos e não objeto e onde as limitações à autonomia humana sejam removidas". (HOFFMAN, 1987, p. 236)

A quarta perspectiva é a "domination". Nesta, a mediação internacional é uma forma de dominação, uma ferramenta utilizada pelos Estados ricos e 
poderosos para impedir mudanças fundamentais na estrutura do sistema internacional, o que os conflitos poderiam permitir de alguma forma. Defendem ainda que o conflito provem da estrutura do sistema capitalista. O trabalho de análise de conflito consiste em desenvolver uma teoria explicativa capacitada em não somente explicar os últimos casos de conflito, mas também prever a incidência e os resultados futuros. ( KLEIBOER, 1996, pp. 384-385)

Todos os tipos de mediadores possuem algumas condições básicas para a mediação ser realizada, sendo que o mediador deve considerar a natureza do litígio, o calendário da intervenção, as percepções das partes em conflito e as diversas disputas que podem estar envolvidas no conflito. (BERCOVITCH; HOUSTON, 1996, p. 23)

Podemos distinguir em cinco categorias a natureza do problema que resulta no litígio: questões de soberania, que envolvem adversários incompatíveis reivindicando um território especifico; questões ideológicas, que podem se referir à natureza do sistema político, aos valores fundamentais e/ou às crenças; as questões de segurança relativas a fronteiras e territórios; questões de autodeterminação e independência nacional, as quais levam os indivíduos ao conflito; e uma categoria residual em que se encontram todos os demais tipos de conflitos. De acordo com a base de dados analisada por diversos atores, os litígios motivados por questões territoriais e políticas são mais propícios de serem bemsucedidos em comparação com questões ideológicas e de identidade. Devemos considerar que os conflitos muitas vezes se enquadram em mais de uma categoria. (KLEIBOER, 1996, p. 364)

A mediação só consegue ocorrer quando as partes percebem as consequências da escalada do conflito e não desejam mais sustentá-las. Neste momento considera-se que o conflito está maduro e a terceira parte tem mais propensão à intervenção bem-sucedida. Até este momento, as partes estão empenhadas em suas posições e no enfrentamento político. Para a mediação ter sucesso é necessário que as partes sejam impulsionadas a reavaliar as suas políticas e posições. Os mediadores devem fazer com que as partes acreditem terem chegado a uma situação intolerável e que a melhor saída para o impasse é a mediação. Isso significa que as partes precisam ter a percepção de que a sua opção de política unilateral e sem negociação é a forma menos provável de alcançar o resultado aceitável. (ZARTMAN; TOUVAL, 2007, p. 445) 
O contexto do conflito também deve ser considerando. Os aspectos políticos, o modo como os fatores internos, a composição política, social e cultural, as diferenças culturais e étnicas e o grau de homogeneidade, afetam o sucesso ou fracasso da mediação. O poder das partes também afeta a mediação, pois quanto menos desigual for a capacidade das partes, mais facilmente elas irão aceitar realizar a mediação. O relacionamento anterior entre as partes tem que ser considerado na mediação, pois as partes não estão isoladas no tempo e espaço; dessa forma o histórico das relações das partes conta no momento da mediação e no resultado do conflito. (BERCOVITCH; HOUSTON, 1996, p. 20) O relacionamento anterior das partes com o mediador também é bastante relevante, principalmente quando considerarmos as ONGs como mediadoras e o poder piramidal. Pois ao escolher a ONG como mediadora a interação com todos os níveis do conflito se fortalece e a mediação se baseia mais primordialmente nos poderes: informacional e referente.

\subsubsection{A mediação tradicional}

A mediação internacional em sua visão tradicional é entendida como uma abordagem de "political problem solving", o qual defende o conflito internacional como uma ameaça que deve ser evitada ou controlada por um esforço sistêmico de gestão de conflito, incluindo a mediação. Nesta visão, o conflito é compreendido como uma construção social e, portanto, subordinado a situações especificas, à dinâmica de percepção e decisão por parte dos atores de política externa. A mediação tem como principal objetivo a mudança fundamental de atitudes e comportamento das partes, resultado de uma relação de confiança, pois o conflito é determinado devido à visão dos atores sobre a questão em disputa. Na solução do conflito o processo de desenvolvimento e sustentação de um diálogo entre as partes é tão importante quanto os seus resultados no curto prazo. (KLEIBOER, 1996, p. 381)

Proveniente disso, esse tipo de mediação necessita de qualquer ator importante na cena internacional, o qual tenha como objetivo principal melhorar o processo de construção de confiança entre as partes. A habilidade do mediador de manter a comunicação entre as partes tem uma importância vital para com o seu compromisso com a paz como um valor em si mesmo. Ao mesmo tempo, o 
mediador tem de estar ciente do ambiente político onde opera e como isto pode afetar o comportamento das partes. (pp. 381-382)

É essencial para o sucesso da mediação que a comunicação seja iniciada e se mantenha produtiva durante o processo, através da aplicação de diferentes técnicas as quais objetivam reduzir os conflitos interpessoais e inter-grupos existentes. Neste sentido, as técnicas devem ultrapassar as tradicionais formas de mediação, aproveitando as experiências na comunidade e organizações e em situações anteriores. (p. 382)

\subsubsection{Mediação de segunda via}

A mediação de segunda via é complementar a mediação tradicional, o objetivo dela é auxiliar e preparar o caminho para a mediação tradicional entrar no conflito. Geralmente esse papel é realizado por países pequenos, organizações internacionais, organizações não-governamentais e outros atores que não exercem a mesma influência do que as grandes potências. Hoffman coloca que o mediador de segunda via possui o seu comportamento moldado pela teoria da facilitação e não consegue se sustentar no processo sozinho. O mediador de segunda via seria uma complementação as iniciativas da terceira parte. A falta de poder para lidar com a assimetria entre as partes é uma das desvantagens da mediação de facilitação. Jones coloca que esta situação impede que o mediador imponha compromissos normativos às partes. (JONES, 1999, p. 59)

O papel da facilitação é entender os problemas que enfatizam o conflito, tais como a má comunicação entre as partes a qual leva a distorção de informações e imagens do outro de forma negativa, atrapalhando assim a negociação e minando a confiança que o mediador tem que desenvolver para conseguir firmar um compromisso. Outro objetivo desenvolvido pela facilitação é a quebra do circulo de desconfiança através de negociações de pequena escala, ou seja, negociações envolvendo o nível mais básico da sociedade ou dos grupos armados e podendo ir até os chefes dos grupos. As negociações serão realizadas em segredo e a terceira parte criará um diálogo emancipatório. Então, pode-se perceber que os objetivos são em longo prazo, ao contrário da mediação tradicional.

Todavia, os mediadores não-oficiais não se limitam ao papel de facilitador na mediação de segunda via, eles também podem ter um papel mais ativo na 
chamada mediação da faixa um e meio. Esta faixa, normalmente, possui duas formas de mediação: a direta onde o mediador não oficial tenta mediar a resolução do conflito ou questões especificas; e consulta no qual a terceira parte age como um facilitador informal, o qual tem o papel de resolver os problemas pelo diálogo entre os tomadores de decisão e negociadores, tentando assim ajudar as partes a analisar e lidar com suas atitudes antagônicas e as questões de suas relações. (CHIGAS, 2007, p. 555)

Os agentes das ONGs portam-se como mediadores principais ou conciliadores no tipo de mediação de via um e meio sejam pelo acolhimento e facilitação de conversas ou pelo fornecimento de informações, o que aconteceu no ACEH, no Burundi e em Moçambique, como será explicitado posteriormente. (p. 556)

A mediação via um e meio permite que as ONGs trabalhem no modelo piramidal, o qual considera todas as fragmentações de liderança e trabalha com todos os níveis dela as dividindo em três níveis diferentes. O primeiro nível encontra-se os líderes políticos e/ou militares que representam o governo legitimo ou movimentos de oposição. O segundo nível representa as meias lideranças, cuja amplitude é alargada incluindo o círculo empresarial, religiosos, líderes trabalhistas e educacionais, os quais poderiam ser relacionados informalmente com os dirigentes do governo, contudo, estão mais ligados com a população. Pois, os lideres populares compreende melhor os impactos do conflito e as suas origens, no entanto, são os mais marginalizados no processo de mediação. O terceiro nível é composto pela população local, é onde reside o real processo de reconciliação e é o grupo que recebe os custos e benefícios diretos da mediação. (LEDERACH, 1997) A mediação baseada no modelo piramidal é o ideal para os conflitos complexos, pois envolve todos os níveis da sociedade. Porque, nos conflitos complexos a fragmentação do poder, da liderança e da legitimidade é intensa, e o Estado está enfraquecido e perdeu o seu papel central como foi nas décadas anteriores, consequentemente, é necessário que a mediação trabalhe em diferentes níveis e, em muitas circunstâncias, de modo simultâneo. (ZARTMAN; TOUVAL, 2007, p. 445)

\subsubsection{Mediação multipartidária}


Em 1990, Diamond e Mcdonald defenderam um novo modelo de mediação, o multipartidário (Multi-Track). Os autores colocavam que devido à nova natureza dos conflitos, os atores oficiais não conseguiriam lidar sozinhos com os desafios apresentados pelos conflitos. Em decorrência eles ampliaram o conceito de mediação de duas vias, pois perceberam que os atores de origens e habilidades variadas podem fazer a diferença na mediação. (DIAMOND; Mcdonald, 1996)

Sendo assim, a diplomacia multipartidária é composta por nove faixas que se interligam em um quadro conceitual e prático que serve para compreender esse complexo sistema de atividade de pacificação. As nove faixas são: governos (paz através da diplomacia); profissionais não-governamentais; negócios (paz através do comércio); cidadão privado; investigação, educação e formação (paz através do aprendizado ou da defensoria); religião (paz através da utilização da fé); financiamento (paz através da promoção de recursos); e comunicação e meios de comunicação social.

Cada uma dessas nove faixas representa um mundo em si mesma, mas, ao mesmo tempo, existem milhares de sobreposições, de colaboração e de atividades complementares; dessa forma cada uma das faixas influência as demais. A diplomacia multipartidária olha de maneira interdependente para cada uma dessas faixas, analisando assim todo o sistema.

Como podemos observar, a mediação multipartidária é realizada por diversos atores atuando ao mesmo tempo e de maneiras diferentes no conflito. Dessa forma existe uma independência entre elas e uma preponderância de um dos atores na mediação. Ou seja, segundo os autores, são necessárias todas as faixas na mediação para conseguir atuar de modo eficiente, dando assim uma posição marginal a cada uma das faixas. Porém, pode ser observado mais claramente nos exemplos estudados durante esta dissertação que os mediadores de ONGs podem ter um papel destacado na mediação. Eles podem e devem, em algum momento, receber auxilio de outros atores, tais como Estados e organizações internacionais, e essa ajuda pode ser indispensável em determinadas situações, no entanto, isto não tira a importância e preponderância deles na mediação. Considerando isso, a mediação realizada pelas ONGs, nos casos aqui estudados, irá se aproximar mais da faixa um e meio, onde as ONGs atuam como mediadores principais e não como complementos a mediação de outros atores. 


\subsubsection{Tipo de mediadores}

\subsubsection{Indivíduos}

Os mediadores individuais são considerados pela teoria de resolução de conflitos como sendo mediadores tradicionais, assim como os Estados. Normalmente, os mediadores individuais são representantes de governos ou organizações internacionais, e acabam por participar de uma série de interações formais com os altos funcionários dos países em conflito. Devido a isso, os mediadores individuais podem até mesmo participar de encontros em nível individual, contudo, não podem ser desconsideradas as consequências das apresentações formais. Dessa forma, há diversas maneiras dos mediadores individuais conseguirem a sua legitimidade. Quando eles representam os Estados a sua legitimidade, por exemplo, é proveniente dele, ou seja, o Estado transfere esse poder. (BERCOVITCH; SCHNEIDER, 2000, p. 147)

Todavia, a mediação individual não se resume aos representantes de governos ou organizações internacionais, ela também inclui indivíduos que possuem o comprometimento, o conhecimento, a experiência em resolução de conflitos e são reconhecidos pelas partes em conflitos, e é desses fatores que deriva a sua legitimidade. (BERCOVITCH, 2004)

Obviamente, os mediadores individuais são os que mais divergem sobre a sua natureza, capacidade e recursos para executar as tarefas exigidas pela mediação. Eles podem partir de diferentes crenças, valores e atitudes, o que possibilita uma maior flexibilidade para os mediadores. Outro fator que contribui para a maior flexibilidade dos mediadores individuais é a mediação ser baseada diretamente nas experiências e capacidades do mediador, do contexto internacional e dos estímulos que incidem sobre eles. (BERCOVITCH; SCHNEIDER, 2000, p. 147)

Contudo, devido a pouca capacidade dos atores individuais para realizar as tarefas da mediação, ela é necessariamente limitada à comunicação e a facilitação das estratégias realizadas por outros atores. (BERCOVITCH, 2004)

\subsubsection{Estados}


O Estado ainda é o principal mediador internacional e continua a ser a principal e mais bem-sucedida organização política, apesar da globalização. (BERCOVITCH; SCHNEIDER, 2000, p. 147) E, por causa disso, é levado a intervir em conflitos que podem prejudicar os seus próprios interesses. Quando um Estado decide mediar um conflito, por acreditar que ele é realmente uma ameaça à paz e segurança internacional e à estabilidade da região ou porque tem interesses no conflito, o Estado pode utilizar-se de todo recurso a sua disposição através dos seus representantes oficiais. Ao contrário dos demais mediadores, os Estados possuem considerável recursos tangíveis, meios para mobilizar esses recursos e líderes com mandato para utilizá-los. (BERCOVITCH, 2004) Em contrapartida, eles possuem um alto custo político e alto grau de burocracia quando decidem realizar uma mediação, o que pode diminuir a sua flexibilidade e a rapidez de sua resposta no processo da mediação.

No momento que um Estado é convidado a realizar a mediação, normalmente, envolve o serviço dos seus cargos mais altos de decisão, ou seja, o representante do Estado que vai cumprir o papel de mediador frente a mídia internacional é o presidente do país, o ministro de relações internacionais ou o secretário de estado. O tipo de mediação realizada por esses indivíduos é determinado pela posição que eles ocupam em seu país, a margem de manobra dada a eles por determinação política, os recursos disponíveis e a capacidade e orientação política dos seus países. (BERCOVITCH; SCHNEIDER, 2000, pp. 147-148)

Assim, a diferença de capacidades e recursos entre os Estados podem determinar a quantidade de vezes que cada Estado vai ser escolhido para realizar uma mediação. Essa diferença vai se sobrepor à igualdade jurídica existente entre os Estados no direito internacional e perante as organizações internacionais, segundo Bercovitch e Houston, pois, ambos acreditam na importância dos recursos para realizar uma mediação. (pp. 147-148)

\subsubsection{Organizações internacionais e regionais}

Devido à maior complexidade dos conflitos internacionais, considerados como intratáveis ou complexos, os Estados vêm perdendo as suas capacidades de liderarem a mediação ou facilitar uma solução em conflitos longos e intensos. O 
envolvimento neste tipo de conflito possui um maior risco político, que muitas vezes os Estados não desejam ou são incapazes de assumir. Dessa forma, outros atores começaram a ter um maior protagonismo na mediação internacional. Em decorrência, desde o fim da Guerra Fria cresceu a participação de organizações internacionais, regionais e atores não oficiais, como ONGs, na mediação internacional e nas Missões de Paz.

A motivação das organizações internacionais e regionais vem, na maioria das vezes, desde a sua criação e está presente nas suas Cartas de Fundação, como é o caso das Nações Unidas (ONU), a qual possui como um dos seus objetivos institucionais básicos a manutenção da paz internacional. Consequentemente o Secretário Geral e seus representantes regionais devem sempre estar preparados para o papel de mediador ou negociador. (MERRILLS, 2000, p. 28) A ONU, desde a sua criação, encoraja e utiliza a resolução pacífica de conflito primordialmente, inclusive no artigo 2(3) determina que: “Todos os Membros deverão resolver suas controvérsias internacionais por meios pacíficos, de modo que não sejam ameaças à paz, à segurança e à justiça internacional”. (CARTA DAS NAÇÕES UNIDAS, 1945)

Como na ONU, uma das principais funções das organizações regionais é oferecer aos seus membros um fórum de consulta, o qual eles podem utilizar em caso de disputas em que as relações diplomáticas tenham sido interrompidas. (MERRILLS, 2000, p. 266) As organizações regionais também podem participar das Missões de Paz, que em sua maioria são organizadas pela ONU. Porém, as organizações regionais possuem limitações, que são as restrições geográficas, os recursos financeiros e militares e a incapacidade, muitas vezes, de lidar com disputas que ocorrem dentro dos seus Estados Membros. Essas limitações variam de acordo com a região e a instituição. (p. 173)

Um dos grandes problemas enfrentado pelas organizações internacionais e regionais é que elas estão sujeitas às políticas particulares e aos interesses dos seus Estados Membros. Dentro da ONU isso pôde ser claramente observado no congelamento do Conselho de Segurança durante a Guerra Fria devido à disputa de interesses entre os Estados Unidos e a antiga União Soviética. Isso prejudica a ação das organizações internacionais e regionais como mediadores e pode tornálos mediadores secundários, enquanto os Estados assumem uma mediação mais direta. Considerando isto, percebe-se que a maioria dos acordos são realizados 
através delas e não por elas, ou seja, os Estados as utilizam somente como um local/fórum para realizar a mediação e as organizações não possuem um papel ativo nas negociações. (p. 270)

Outra das principais dificuldades enfrentadas pela ONU e as demais organizações internacionais ou regionais no momento da mediação é o efeito legitimador e de reconhecimento. Em muitos conflitos uma das partes do conflito, que não possua uma legitimidade legal, por exemplo, guerrilheiros e milícias, recorrem à mediação realizada pela ONU para alcançar uma autoridade moral. (BARNETT, 1995, p. 428) Esse efeito e a própria institucionalização das organizações internacionais e regionais impedem que elas entrem em contato com todas as partes do conflito, devido à ilegitimidade dessas partes. Esta dificuldade não se limita as organizações internacionais, mas os Estados também enfrentam o “jogo do reconhecimento" ou "fator legitimador" ${ }^{14}$ na mediação. (MITCHELL, 1992, p. 277) Ao contrário das organizações internacionais, regionais e dos Estados, as ONGs não possuem um poder tão grande no cenário internacional, o que é uma vantagem para elas, pois as permitem aproximar-se de grupos considerados imorais e ilegítimos, podendo levá-los a mesa de negociação. No contexto dos conflitos complexos essa capacidade de aproximação é ainda mais importante, porque esse tipo de conflito é composto basicamente por grupos considerados ilegítimos e imorais. (ver CHIGAS, 2007, p. 563-566)

\subsubsection{Organizações não-governamentais (ONGs)}

Como ocorreu com as organizações internacionais e regionais, as ONGs começaram a se envolver mais fortemente na mediação internacional no pósGuerra Fria, pois, como já foi observado, os conflitos tornaram-se mais complexos e em muitos casos os Estados não desejavam ou não podiam participar do processo de mediação, passando, assim, parte da responsabilidade para as ONGs. O leque de intervenções realizadas pelas ONGs é amplo e vai muito além da noção tradicional, na qual elas atuam somente como intermediárias, facilitadoras ou mediadoras que atuam entre os lados de um conflito, o que inclui

${ }^{14}$ O "jogo do reconhecimento" é o processo no qual insurgente, rebeldes ou milícias cria um sistema que qualquer interação com esses atores será vista como representante legitimo perante o cenário internacional. (MITCHELL, 1992, p. 277) 
advocacia e o desenvolvimento de atividades sociais e econômicas. (CHIGAS, 2007, p. 564)

Os atores de ONGs não estão preocupados somente com a assinatura de um acordo de paz. A principal função deles é a de "cura", lidar com questões fundamentais do conflito, objetivando alcançar a reconciliação e mudança de atitudes entre as partes e não somente a solução superficial do conflito. (ver LANZ; SGUAITAMATTI, 2009, pp. 6-7)

Esses atores podem operar de forma informal e secreta nos conflitos, por não serem representantes oficiais e terem um menor risco político envolvido no processo, ou seja, as partes não precisam temer perdas na sua imagem por estarem se envolvendo com uma terceira parte ou iniciarem negociações com os demais atores; e os mediadores podem oferecer serviços e têm mais facilmente acesso às partes em que diplomatas oficiais são vistos com desconfiança. Além disso, esses atores podem ser menos inibidos na sua abordagem no conflito, e podem apelar às partes pela permissão de trabalhar em todos os níveis do conflito, para assim alcançar uma solução duradoura para os seus problemas. (BERCOVITCH, 2004) A abordagem da mediação em todos os níveis do conflito é fundamental na mediação de conflitos complexos, pois, como já foi dito, o conflito atinge todos os níveis da sociedade e possui como uma das principais características a fragmentação das forças e do poder político e territorial.

Outra vantagem das ONGs perante os demais atores é que elas possuem uma informalidade e falta de institucionalização que lhes permitem ser mais criativas e menos inibidas na posição política que advogam. Esses atores também se tornaram ativos e importantes contribuintes em pesquisas para instituições e propostas conducentes à paz. Consequentemente, essas organizações incorporam muitas das características associadas à imparcialidade. (BERCOVITCH; SCHNEIDER, 2000, p. 148)

Um tipo de ONG que vem crescendo no papel considerado como "gestor de conflito" é o das ONGs religiosas. Elas já trabalhavam na área do conflito, no entanto, posteriormente foram adquirindo mais responsabilidade quanto à resolução do conflito e à reconstrução da sociedade pós-conflito. Para isso elas operam a partir de filiações religiosas como base dos seus recursos. Os atores religiosos que atuam nos conflitos são muito variados, tais como leigos, lideres religiosos, organismos multi-religiosos, os quais se envolvem em diversos 
esforços para consolidar a paz, como por exemplo, educação para paz, reconciliação, defesa da democracia para o desenvolvimento social, resolução de conflitos, acompanhamento de eleições e tratamento de traumas. (SAMPSON, 2007, pp. 273-274)

\subsubsection{Comportamento dos mediadores}

O comportamento do mediador influencia fortemente o resultado da mediação e como ela vai se desenvolver, no entanto, ele pode variar e não existe o certo ou o que deve ser utilizado. O comportamento varia de acordo com o mediador e é influenciado por diversos fatores, como a natureza do conflito e a identidade das partes (BERCOVITCH; HOUSTON, 2000, p. 170), ou seja, os atores que vão realizar a mediação em conflitos complexos precisam se adaptar ou então atores mais adequados para a função devem assumir esse tipo de mediação.

O resultado da mediação é subordinado tanto às variáveis do contexto como ao comportamento ou atividades do mediador. O comportamento do mediador pode ser considerado em termos de atividades, táticas ou técnicas. (WALL, 1993, pp. 165-166)

\subsubsection{Imparcialidade}

A importância da imparcialidade na mediação é um dos temas na literatura de resolução de conflitos que mais gera debate sobre a sua influência ou não na eficácia da mediação. Existem três grupos distintos que possuem forte argumentação na defesa da imparcialidade ou defende que os mediadores devem influenciar a mediação. Conceitualmente devemos fazer uma diferença de que tipo de imparcialidade está sendo tratada, pois ela pode se referir tanto em relação à interação como à aparência. Além disso, ela pode estar relacionada a atitude do mediador em relação às partes em conflito ou ao jogo do mediador em relação às questões substanciais dos conflitos e ainda poderia se referir a ambas as situações. Todavia, os analistas concordam que a imparcialidade é essencial na percepção das partes em conflito, sendo assim, não existe uma grande discordância quanto às partes conceituais, mas no efeito que a imparcialidade tem sobre o resultado da mediação. (KLEIBOER, 1996, p. 369) 
A primeira corrente, defendida por Miall, Hume, Young e Jackson, coloca que a imparcialidade é fundamental para o sucesso da mediação, pois somente com ela as partes irão confiar no mediador e, consequentemente, irão aceitá-lo na mediação. (p. 369)

O segundo grupo de analistas composto por Touval, Kochan, Smith e Jabri defende que a imparcialidade não é fundamental. O essencial é que se tenha confiança entre as partes e o mediador, o que não está necessariamente relacionado com a imparcialidade. A concepção da aceitação de um mediador não se baseia no distanciamento em relação ao conflito ou da sua objetividade nas questões, mas na conexão de confiança e no relacionamento que as partes em conflito possuíam com o mediador. Porém, eles salientam que este tipo de mediador - o que está mais envolvido no conflito - é mais provável em contextos sociais primários, nos quais a tradição foi menos corroída pela modernidade e as relações pessoais caracterizam as relações políticas, econômicas e sociais. (p. 369) Percebe-se que é este tipo de sociedade que os três conflitos estudados nesta dissertação apresentam.

A necessidade da imparcialidade também é questionada pelo primeiro ponto de vista, mostrando que o mais importante é a confiança das partes no mediador e os contatos sociais deste com os litigantes. (RICHMOND, 1998, p. 709)

Já um terceiro grupo, composto por Bercovitch, Wille e Zartman, defende que a aceitação do mediador não está condicionada à confiança ou à imparcialidade, mas na capacidade do mediador em direcionar as partes para determinado ponto. (KLEIBOER, 1996, p. 370) A aceitação da mediação é baseada em um cálculo de custo e beneficio, segundo eles. Consequentemente, a imparcialidade e confiança do mediador não são tão importantes para as partes quanto o cálculo das consequências da aceitação ou não da mediação e do mediador. Ou seja, as partes só aceitam, inicialmente, a mediação daqueles que elas acreditam possuir a capacidade de alcançar resultados aceitáveis para elas. $\mathrm{O}$ mediador tem que possuir a capacidade de mover as partes em sua direção de interesses, o que é mais importante do que a imparcialidade. (BERCOVITCH; HOUSTON, 2007, p. 26)

A capacidade de mover as partes em uma direção é denominada como poder do mediador e depende do poder que é dado a ele pelas partes em conflito, cuja aceitação do mediador vai depender da probabilidade dele (poder potencial) em 
produzir resultados aceitáveis pelas partes. (ZARTMAN: TOUVAL, 2007, p. 447) Para exercer influência e estruturar a interação entre as partes, os mediadores precisam dos poderes, os quais são compreendidos como sendo uma vasta gama de meios e recursos, que podem reforçar a capacidade de alcançar um desfecho favorável na mediação. Os objetivos do mediador que se utiliza desses poderes são de alterar as condições físicas do conflito e moldar os resultados. Esses objetivos são melhor alcançados quando o mediador não é imparcial e possui recursos que são desejados pelas partes em litígio. (BERCOVITCH; SCHNEIDER, 2000, p. 149)

Um mediador que possui um comportamento engajado e destinado a obter informações e exercer influência no sentido de determinadas situações persuadindo as partes, tem o seu trabalho facilitado quando não é um mediador imparcial e quando ele possui recursos, os quais é valorizada pelas partes do conflito. (KLEIBOER, 1996, 370) O que é evidente na visão do terceiro grupo é que a mediação é um processo que envolve o exercício de poder. (SMITH, 1994, p. 446) Assim, fica claro que os atores que menos precisam se preocupar com a imparcialidade são os Estados, os quais possuem recursos e capacidade de utilizálos para influenciar as partes, enquanto as organizações internacionais, regionais e as organizações não-governamentais teriam que se preocupar com ela ou apostarem nos seus relacionamentos pessoais para terem a confiança das partes.

O debate engloba também o debate sobre dois tipos básicos de mediador: o mediador puro ou tradicional e o mediador de poder.

O mediador puro deve confiar nas suas habilidades e personalidade para a construção de confiança, comunicação e para alcançar um acordo entre as partes, pois ele não possui poderes suficientes, que permitem que ele influencie as partes para alcançar o resultado desejado ou incentiva as partes a procurá-lo como mediador para converter o seu poder em beneficio próprio. Para este tipo de mediador a imparcialidade é fundamental, pois é este fator que proporciona a legitimidade deles na mediação. Na realidade, eles definem a sua mediação em termo de imparcialidade. Além disso, o mediador puro não se utiliza de barganha para negociar com as partes devido a seu reduzido poder. (p. 447)

O mediador puro seria o condutor de informações com o objetivo de gerar cooperação entre as partes. (JONES, 1999, p. 18) Em contra posição, ao mediador de poder que utiliza as informações para influenciar as partes em litígio. (SMITH, 
1994, p. 446) Isso não quer dizer que o mediador puro não possui nenhum tipo de poder, mas o seu poder não é medido no sentido material, mas pelo poder de comunicação.

O mediador de poder ou tradicional possui como principal característica o poder, que lhe permite influenciar as expectativas e o comportamento das partes em litígio para fazê-las alcançar um acordo. A influência é feita por meio de capacidades e poderes que o mediador possui e podem ser oferecidos para as partes, que podem referir-se à apoio político e a recursos econômicos. (p. 446)

Todos os lados do debate possuem argumentação válida, dependendo de como a mediação é definida. Segundo Smith, é injusto fazer uma comparação entre a maior eficácia da mediação pura ou de poder, pois ambas as opções terão que enfrentar obstáculos na mediação. (p. 448)

\subsubsection{Perspectiva}

Para conseguir realmente ter uma análise do processo de mediação é necessário olhá-lo de dentro e não do ponto de vista externo, transformando em estático e unilateral, como a maioria da literatura faz. Ao analisarmos o processo de mediação por uma perspectiva interna, podemos observar que o conflito é um fenômeno muito diferente do que a visão tradicional apresenta. O conflito é um processo dinâmico e os adversários podem ter opiniões muito diferentes. Sendo assim, a mediação é uma interação recíproca entre as partes e os mediadores. (RICHMOND, 1998, p. 721)

As abordagens tradicionais de mediação defendem que todos possuem um único objetivo, que seria o estabelecimento de um compromisso, no entanto, o conflito é fluido e existem visões conflitantes. Pode ocorrer do mediador ter percepções diferentes ou cometer equívocos durante o processo de mediação, o que resultaria em obstáculos que são independentes da definição de sucesso de mediação usada. (p. 707)

Percebe-se, assim, a importância da percepção não somente das partes em relação ao mediador, mas também do mediador e das partes entre si, pois as partes e o mediador podem ter objetivos diferentes e compreenderem o seu papel diferenciadamente. 
A percepção de cada uma das partes do conflito e do mediador é resultado da relação entre eles. Para tanto o sucesso da mediação vai depender da percepção de todas as partes do poder, os objetivos e as relações que eles desenvolvem uns com os outros, além do papel que o mediador vai desenvolver durante todo esse processo. (pp. 708-709)

No entanto, a percepção das partes não é influenciada somente pela relação entre as partes com o mediador. A percepção e a identidade das partes podem ser fortemente influenciadas pela cultura deles. (BERCOVITCH; ELGSTRÖM, 2001, p. 12) A identidade ainda pode ser definida pela percepção e a partir das crenças das partes. Sendo assim, a cultura das partes e do local em conflito influencia fortemente a mediação e em como as partes irão entendê-la. (p.14)

Então, obviamente, a cultura é determinante para o sucesso da mediação, contrariamente o que é defendido por alguns atores de mediação não é somente o poder, os recursos e os interesses que determinam o sucesso ou fracasso da mediação (p. 1), pois, considerando que os interesses estão inseridos no contexto cultural e os interesses não são fenômenos objetivos, na realidade, eles são socialmente construídos e consequentemente estão ligados à cultura do local e das partes. Já o poder é um conceito complexo e que está diretamente ligado à legitimidade e, portanto, à cultura. (p. 11)

A cultura do mediador vai influenciar imediatamente na perspectiva, na abordagem e na estratégia que o mediador vai desenvolver e, consequentemente, influenciam não somente a comunicação em relação às partes, mas também a manipulação e a formulação de estratégias. (p. 7) Além disso, o mediador baseiase nas suas qualidades pessoais e ações para determinar como ele vai desenvolver as percepções das partes, as quais também são influenciadas pelas exigências que as partes fazem perante o mediador. Contudo, deve ficar claro que as percepções são mutáveis, possibilitando a mudança delas durante o processo de mediação e o mediador possui relevante papel nessa modificação, permitindo assim, aumentar o desejo das partes em resolver as suas questões por meio da mediação. (RICHMOND, 1998, p. 709)

Estereótipos culturais realizados pelo mediador ou seus parceiros é outra questão referente à cultura que deve ser considerado, pois eles podem resultar em suposições prematuras sobre suas intenções e tendências, levando a conclusões quanto aos motivos que levam a uma solução negociada. (BERCOVITCH; 
ELGSTRÖM, 2001, p. 12) É completamente irreal acreditar que mediadores desinteressados podem interferir em qualquer tipo de conflito de forma genérica, independente da natureza do conflito, dos problemas e das partes envolvidos. (p. 15)

A legitimidade e o poder relativo das partes estão diretamente relacionados ao início da mediação e o papel que eles percebem para o mediador. O papel inicial do mediador e a visão das partes em relação ao mediador têm total relação com os motivos que levaram os litigantes a aceitar a mediação.

Em algumas situações as partes possuem uma posição firmemente contrária à mediação; caso isto ocorra, cabe ao mediador e a parte que deseja a mediação e convencer os disputantes contrários. (RICHMOND, 1998, p. 710)

O mediador também pode ter dificuldade caso uma ou mais partes acreditem que o mediador está favorecendo um dos disputantes. Esta situação tem dois tipos de reação: a primeira é que a parte que sente-se prejudicada e retira o seu aval à mediação por acreditar que o mediador é injusto; a segunda, é que as partes continuem a aceitar a mediação por acreditar que ainda é a alternativa mais vantajosa. Na segunda alternativa a mediação é preservada, pois o essencial é que as partes considerem a mediação como a melhor alternativa. Ao mesmo tempo, as acusações de imparcialidade podem ser devido à insatisfação de alguma das partes porque aos seus objetivos não foram alcançados pela mediação e não devido à real parcialidade do mediador por uma das partes. (p. 717)

O status do mediador ainda pode ser enfraquecido durante o processo da mediação, o que gera sérios problemas para o processo. Isso ocorre, por exemplo, quando o mediador tenta balancear o poder entre uma parte mais fraca e outra mais forte e o resultado é o prejuízo da parte mais fraca, pois o mediador não poderá mais continuar exercendo esse papel.

Ainda deve-se considerar que as partes não são concisas, elas possuem várias subdivisões as quais podem não estar de acordo quanto aos objetivos da mediação. Por exemplo, enquanto uma das subdivisões não deseja o acordo à outra só pensa nos ganhos possíveis perante a mediação. Obviamente isto atrapalha a mediação, pois acontece uma concorrência dentro do grupo para definir quais serão os objetivos defendidos pela parte na mediação. (p. 710-713)

O “jogo de reconhecimento", como já foi colocado, é um ponto importante e que atrapalha a realização da mediação. Quando a mediação é realizada por certos 
tipos de mediadores, como organizações internacionais, organizações regionais e Estados, os quais possuem caráter oficial, existe a possibilidade de quando estes atores começarem a realizar a mediação, grupos rebeldes e guerrilheiros, os quais não possuam legitimidade e reconhecimento internacional e nos seus países, procurem o apoio dos mediadores para conseguir reconhecimento e legitimidade a sua causa. (pp. 712-713)

A religião é outro ponto que vem ganhando importância no pós-Guerra Fria devido à motivação supostamente ou não religiosa dos conflitos e na definição da comunidade de conflito, por exemplo, do crescimento de mediadores com vinculo religioso, o que interfere nas percepções envolvidas na mediação.

A filosofia religiosa acrescenta uma nova dimensão na discussão de resolução de conflito ao introduzir a noção de reconciliação, conceito proveniente da tradição judaica-cristã que incluí elementos dos ensinamentos Hindu, Islâmico e budista. O conceito teológico de reconciliação sugere que o relacionamento quebrado e que levou ao conflito pode ser reparado, podendo desenvolver uma relação construtiva entre as partes em conflito. (NATSIOS, 2007, p. 358) A filosofia religiosa da reconciliação é usada pelos mediadores religiosos e influencia fortemente os mediadores provenientes de outras filosofias, pois o conceito de reconciliação tem aplicação fundamental em sociedades que passaram ou passam por conflitos complexos.

\subsubsection{Poder}

O poder é um dos fatores determinantes para a atividade da medição, no entanto, não estamos tratando do poder entendido tradicionalmente ${ }^{15}$. O mediador exerce o seu poder ao focalizar a atenção das partes quanto ao custo de continuar a luta armada em vez de realizar um acordo negociado. (AALL, 2007, p. 480)

Na literatura de mediação existe um debate sério quanto à importância do poder na mediação eficaz. Para autores como Bercovitch, Wille, Anagnoson, Touval e Bookmire a influência do mediador é uma condição necessária para o sucesso da mediação. Em contrapartida, Yarrow afirma que o pouco poder político do mediador pode facilitar o sucesso da medição, pois a credibilidade e a

${ }^{15} \mathrm{O}$ poder compreendido no seu sentido tradicional é definido como a capacidade de impor ao outro a sua vontade ou a sua capacidade de impedir que o outro imponha a vontade dele sob você. (AAll, 2007, p. 480) 
sinceridade do mediador são reforçadas pela sua natureza não política e sua incapacidade de estabelecer sanções de qualquer tipo. A falta de poder ainda possibilita um relacionamento mais aberto e descontraído entre o mediador e as partes. Além disso, quando o mediador está estrategicamente fraco pode ocorrer uma maior aceitabilidade dele, isso ocorre pela partes acreditarem que vão obter mais ganhos com a mediação. (KLEIBOER, 1996, p. 371)

Apesar de discordarem sobre o impacto do poder na mediação, os analistas concordam que a mediação pode correr risco quando o mediador utiliza o poder demasiadamente. Pois, primeiramente, as promessas de recompensa por parte do mediador podem gerar dependência das partes em relação a ele em futuras negociações. Além disso, em um sistema de negociação baseada na recompensa, as partes podem estabelecer um preço que o mediador deverá pagar para cada concessão feita por ambas as partes. Nesse caso exigi-se que o mediador continue a exercer esse tipo de influência sobre as partes. A segunda consequência é que quando a solução se dá mediante o uso do poder pode não durar, pois o acordo baseia-se no cumprimento de medidas do mediador e não pela interação de mudança das atitudes e percepções. (LANZ; SGUAITAMATTI, 2009, pp. 9-10)

Claramente o poder não possui uma única natureza e o mediador pode possuir os diferentes tipos de poder em níveis diversificados. Pamela Aall consegue diferenciar seis tipos de poder do mediador:

1. Poder informacional - consiste no mediador transmitir mensagens entre as partes do conflito. Para o emprego do poder informacional é necessário que o mediador possua também o poder legitimo e referente, ou seja, aos olhos de todas as partes do conflito o mediador tem que ser legitimo e forte ao mesmo tempo que honesto. Se essas características estiverem presentes, esse tipo de poder pode ser eficiente para que as partes reconheçam a sua realidade e possam ver além de sua atual situação e, consequentemente, mudar suas percepções dos custos de inicio ou em permanecer no conflito armada frente aos benefícios da negociação. ONGs têm utilizado o poder informacional criativo ao estabelecer relacionamentos e juntar as partes, tal como nas oficinas de gestão de potenciais conflitos no Mar do Sul da China. (AALL, 2007, pp. 481-482)

2. Poder perito - é quando as partes acreditam que o mediador conhece mais sobre a questão em debate ou a mediação em si do que elas. Isso pode ocorrer, em alguns casos, porque o mediador possui experiência prévia e/ou 
relacionamentos que fazer crer que ele possui uma compreensão única do processo de mediação. No entanto, é necessário ter atenção, pois, o poder perito pode complicar a mediação devido à aproximação ou distanciamento do mediador. ONGs vêm utilizando o poder perito na preparação para as negociações, com o objetivo de desenvolver as partes na negociação de problemas comuns. (pp. 482-483)

3. Poder referente - é o poder de influenciar um ou mais lados do conflito devido à valorização pelas partes da sua relação com o mediador. Em alguns casos as partes em conflito não desejam uma forte relação com o terceiro ou que a mediação não seja identificada, por causa do risco de rejeição que as partes correm dentro do próprio grupo por realizarem ou almejarem a reunião com o(s) grupo(s) adversário(s). Esse tipo de poder é muito considerado quando tratamos de mediadores proveniente de ONGs, pois a legitimidade deles, em muitos casos, é derivada do relacionamento que eles possuem com as partes. Considerando isso, os mediadores de ONGs podem ser classificados como "insider-partials", ou seja, mediadores de dentro do conflito, sendo que a influência deles provem de sua(s) relação(ões) com as partes em conflito e eles são aceitos como mediadores por possuírem interesse no resultado e serem afetados diretamente pelo acordo. (pp. 483, 484) As ONGs, em sua maioria, continuam a realizar trabalho no território depois do conflito, então a solução do conflito vai ter efeito direto no seu trabalho.

4. Poder legítimo - derivado da percepção de que o mediador possui o direito de agir como um terceiro, solicitando mudanças no comportamento ou no cumprimento dos acordos realizados. Esse tipo de poder pode ser derivado pelo mediador representar uma forte instituição, a qual as partes acreditem ser difícil ignorar, como de uma longa relação ou que no passado foi possível alcançar a paz por meio desse(s) mediador(es). (p. 485)

5. Poder de recompensa - a capacidade de utilizar incentivo(s) financeiramente ou não - que as partes desejam com incentivo para a realização do acordo de paz. (pp. 485-486)

6. Poder coercitivo - envolve a capacidade do mediador de ameaçar ou utilizar a força para mudar o comportamento ou percepção das partes levando ou não ao acordo. (p. 486) 
Obviamente, ao considerar a mediação realizada por ONGs não se pode incluir os dois últimos tipos de poder, pois elas não são capazes de oferecer incentivos materiais e possuem pouco ou nenhum acesso aos meios de coerção, como armas e controle de recursos, ou ainda a capacidade de estabelecer bloqueios. Entretanto, com a implementação dos demais tipos de poderes as ONGs criam incentivos para que as partes do conflito mudem o seu comportamento. Além disso, a vontade de se envolver no processo de diálogo pelas ONGs e a pressão da comunidade internacional para a realização da mediação podem contribuir significativamente para que os combatentes esgotados pelo conflito, mas que não podem procurar diretamente pela mediação sem ajuda, comecem a realizar o processo de mediação. Ainda a ameaça da retirada das ONGs no papel do terceiro apaziguador pode ser suficiente para que as partes reconsiderem as suas posições. (p. 486)

É fundamental para a mediação que o mediador possua influência sobre as partes em conflito. Deve se considerar que existem diferentes tipos de influência, os quais podem ou não estar combinados com os poderes. A primeira influência é a persuasão, a qual é definida pela capacidade do mediador de retratar um futuro alternativo como mais favorável do que permanecer no conflito. A segunda influência é a extração, a capacidade de produzir atrativos devido à posição das partes com o objetivo de mostrar a importância da reciprocidade. A terceira é a rescisão, é a capacidade de se retirar da mediação com impacto, pois o mediador é tão importante para as partes que a sua ameaça de se retirar das negociações faz com que as partes se movimentem. A quarta é a privação, competência de reter recursos provenientes de um lado ou deslocar-los a outros, aqui se situa as sanções. Por último é a influência da gratificação, possibilidade de adicionar os recursos ao resultado como uma forma de incentivar as partes a entrar em um acordo. (ZARTMAN; TOUVAL, 2007, p. 446) Os dois últimos se aproximam fortemente do poder de recompensa e de coerção.

\subsubsection{Estratégia do mediador}

Não é possível classificar todas as estratégias utilizadas pelos mediadores em uma única categoria, pois isso simplificaria demasiadamente a complexidade do processo de mediação. A institucionalização do mediador, as exigências e 
expectativas das partes em relação ao processo fazem com que o comportamento do mediador varie. Ou seja, o que o mediador pode fazer, faz e resolve fazer é determinado pelo contexto e as circunstâncias do conflito. (BERCOVITCH, 1999, p. 130)

Para a mediação ser realizada efetivamente é necessário que os mediadores possuam comportamento e estratégia congruentes com a natureza do conflito e com os objetivos e recursos do mediador. (p. 139) Bercovitch e Houton desenvolveram um estudo no qual concluíram que o comportamento do mediador e as suas estratégias serão determinados pelo ambiente no qual é realizado. $O$ comportamento do mediador e as estratégias utilizadas devem ser analisados conjuntamente com as fontes internas e externas das partes e a influência que elas têm sobre o mediador, pois estes fatores também determinam a mediação. (BERCOVITCH; HOUSTON, 2000, p. 170)

A forma de definir as estratégias é muito diversificada na literatura de mediação internacional, em que cada ator acaba por utilizar da sua própria tipologia. As tipologias, normalmente, dividem as estratégias baseadas no comportamento dos dois tipos mais comuns de mediadores: o tradicional e o facilitador. (p. 170)

Já Touval e Zartman os distinguem através dos principais papéis do mediador e consequentemente sua estratégia: "comunicador", "formulador e "manipulador". O mediador comunicador possui uma conduta passiva, servindo como um canal de comunicação, podendo agir como um contato entre as partes em conflito para transmitir informações, ou seja, servindo como uma ponte entre as partes. $\mathrm{O}$ formulador possui um papel mais ativo na mediação, contribuindo com inovações e ajudando as partes a redefinir questões ou encontrar uma fórmula para a resolução dos seus conflitos. Na realidade, esses dois tipos de mediadores se misturam, sendo a sua divisão somente para fins analíticos. No entanto, se as duas estratégias não conseguirem produzir o efeito esperado, o mediador pode utilizar a sua influência para manipular as partes do conflito, sendo este o mediador manipulador. (ZARTMAN; TOUVAL, 1985, pp. 38-39)

A estratégia da mediação vai além da simples comunicação e facilitação e dessa forma ela é muito mais eficiente. $\mathrm{O}$ mediador pode determinar fatores, tais como: o ambiente da mediação, o número e o tipo de reuniões com as partes, a abrangência da agenda nas reuniões, controle em relação a influência do 
eleitorado, a distribuição de informações e recursos para as partes. O comportamento mais ativo do mediador e estratégias diretas ocorrem quando um mediador expõe e afeta o conteúdo da mediação. Isso pode ocorrer quando o mediador oferece incentivos, recompensas e punições, emissão de intimados e a introdução de novas propostas. (BERCOVITCH; HOUSTON, 1996, p. 28)

\subsubsection{Motivação do mediador}

A motivação do mediador para se voluntariar à mediação depende do tipo de mediador. Alguns mediadores intervêm de maneira preventiva ou defensiva, por acreditarem que a sua intervenção vai levar as partes a chegarem ao acordo antes de prejudicarem os seus interesses. Outra motivação é a busca por um maior prestigio internacional. Os Estados na mediação de poder têm como principal motivação a defesa dos seus próprios interesses. Nestes casos, os Estados incorporam o papel de mediador para impedir que Estados rivais possuam esse cargo e consigam, com isto, expandir a sua influência. (BERCOVITCH, 1999, p. 146) Essa motivação foi muito forte para os Estados Unidos e a ex-União das Repúblicas Socialistas Soviéticas (URSS) em suas áreas de influência durante a Guerra Fria.

As organizações internacionais e regionais possuem em suas Cartas de Criação os motivos que as levariam a intervir em um conflito internacional, tais como a ameaça à paz e à segurança internacional, não sendo permitido a elas intervirem em nenhuma situação além da abrangência da Carta. (RICHMOND, 1998, p. 714)

O valor que o mediador possui no mercado de mediação também é variável. O Estado ou outro tipo de mediador que já mediou diversos conflitos de forma bem-sucedida, possui um poder à curto prazo, o qual é derivado do poder e da influência que aquele mediador possui em determinado momento. No entanto, um currículo de mediação bem-sucedido não é um fator determinante na escolha do mediador. (BERCOVITCH; SCHNEIDER, 2000, p. 167)

Os mediadores não estatais, os quais não possuem interesses tão claramente baseados no poder político e no auto-interesse, possuem uma motivação mais complexa de ser determinada na mediação. As ONGs, por exemplo, estão mais preocupadas com a paz como valor em si mesma. Em muitas situações, elas estão 
buscando alcançar um determinado resultado para a mediação por acreditarem que é o melhor resultado possível para a sociedade e não devido aos benefícios que ele pode trazer para elas. Outra motivação possível é elas aparecerem como uma boa e bem-sucedida mediadora, pois possuem um papel e uma reputação a defender. Um exemplo é o que será abordado nesta dissertação com a Comunidade Sant Egidio, que já realizava um trabalho humanitário em Moçambique e a mediação iniciou-se devido a isto e para assegurar a sua continuidade. No entanto, podemos observar que todos os interventores não estatais têm interesse de reformar a sua posição como mediador por acreditarem que ele tem algo a oferecer, além de reforçar a sua competência e reputação. (ZARTMAN; TOUVAL, 2007, p. 442)

\subsubsection{Atividades e funções do mediador}

A mediação inclui uma ampla gama de atividades que ajudam alcançar uma solução mutuamente aceita pelos adversários, que incluem organização de reuniões, fornecimento um local seguro, formulação da agenda do dia, e até mesmo ajudar a decidir quem deve participar das sessões de negociação. Além disso, as atividades incluem a facilitação de encontros, ajuda aos adversários a realizarem uma melhor comunicação, a melhor compreensão do discurso do adversário, o deslocamento e procedimentos quando uma das partes é presa, e o encontro com cada lado. (KRIESBERG, 2007, p.461) A entrada de novos atores na mediação internacional gera mudanças dentro das funções e atividades do mediador, pois as ONGs realizam diferentes atividades, as quais são mais flexíveis durante a mediação.

Os mediadores podem ainda contribuir para que o acordo seja alcançado acrescentando recursos, propondo opções, construindo confiança e ganhando o apoio do círculo de negociação. (p. 461) Normalmente, são os mediadores oficiais, principalmente os Estados, que possuem a possibilidade de injetar recursos na mediação devido ao seu poder econômico.

Ocorrem diferenças entre as atividades e funções do mediador tradicional, os quais consistem em Estados, organizações internacionais e regionais, e os mediador não-oficial, enquanto o primeiro possui protocolos diplomáticos a seguir o segundo não precisa. Sendo assim, os mediadores não-oficiais têm maior 
flexibilidade, perícia, respondem mais rapidamente às crises e empenham-se em ambientes locais para conseguirem responder aos novos desafios dos conflitos complexos. (CHIGAS, 2007, p. 553) Dessa forma, as ONGs realizam as suas atividades apoiadas na sua criatividade e na inovação, conseguindo assim potencializar os poderes que possuem.

As ONGs podem realizar diversas atividades e funções na mediação. Elas podem ser advogadas de uma das partes, apoiando e defendendo os objetivos desta parte em conflito, podendo promover as suas causas frente à comunidade internacional. (SAMPSON, 2007, p. 280)

Os advogados possuem o papel no inicio do conflito, de educar os menos poderosos sobre as perspectivas de mudanças no equilíbrio do sistema de conflito. Eles devem ser ativos no momento em que a parte mais fraca confronte a parte mais forte para que as suas reivindicações sejam reconhecidas e ganhem força. Quando a distribuição de poder torna-se mais equilibrada e as partes podem negociar de forma igualitária a mediação pode ser realizada. (p. 280) (ver JONES, p. 59)

As ONGs também podem fazer o papel de observadoras estabelecendo uma vigilância sobre a situação do conflito, objetivando que sua presença física evite a violência, corrupção, violações dos direitos humanos ou outros comportamentos considerados ameaçadores ou indesejáveis. (MCKEON, 2005, p. 567-568)

O observador pode ter papel ativo ou passivo na mediação. Quando o mediador adota a maior passividade, ele vai somente se envolver no acompanhamento de eleições, observar ou desempenhar outras funções em que ele não possa modificar o conflito, tendo somente como objetivo verificar se está tudo acontecendo como o planejado. Em sua versão mais ativa, o mediador assegura a sua presença com grupos civis de manutenção da paz ou equipes de paz, posicionando-se entre os lados em situação de conflito ativo, e tornando-se uma parte viva entre as partes em conflito. (SAMPSON, 2007, p. 286)

As ONGs podem ainda atuar com o papel de consultoras, o qual traz pessoas chaves da mediação, devido as suas capacidades pessoais e não como representantes dos seus lados, para fazerem interação direta. Nas reuniões fechadas ao público, que podem ser realizadas por meio de oficinas, os participantes compartilham as suas percepções e preocupações, focando nos interesses e necessidades básicas que sustentam as suas posições, analisando 
conjuntamente as questões subjacentes e seus relacionamentos, dessa forma desenvolvem ideias para alcançarem uma resolução de forma conjunta. (CHIGAS, 2007, pp. 559-560)

As oficinas são destinadas a promover a relação e a confiança entre as partes em conflito, desenvolver canais de comunicação e explorar as opções que poderiam satisfazer os interesses e necessidades de ambos os lados, mudando assim a percepção das partes em relação ao "outro" e ao conflito armado. (ver RICHMOND, 1998) As oficinas trabalham com experiências comuns que podem desenvolver aprendizagens nas quais são introduzidos conceitos e competências para serem usados no próprio conflito. Este processo pode ser realizado em conjunto com as partes ou separadamente, em um primeiro momento. (pp. 559564)

As oficinas/reuniões informais ou reuniões formais precisam ser preparadas, o que é função do mediador. Nesta fase de preparação para negociação o mediador deve considerar dois pontos importantes antes do início da mediação, a logística das reuniões e a localização - como será o local dos encontros, podendo ser aberto ou fechado. Normalmente, por preferência das partes, as negociações são realizadas em locais neutros, entretanto, em algumas situações uma das partes pode aceitar ir ao local que foi escolhido pela outra parte, visando ganhos futuros na negociação ou como sendo uma concessão para mostrar confiança e boa vontade na negociação. A realização do encontro em local aberto ou fechado tem relação com a disposição das partes na interferência do público e da mídia internacional no conflito, o mediador pode utilizar a realização de encontros em locais abertos para chamar atenção da sociedade internacional. Em contrapartida, um local fechado possibilita o endurecimento da posição das partes na negociação. (p. 560)

No primeiro momento da mediação o mediador deve juntamente com as partes decidir quais serão os temas debatidos na negociação. Posteriormente a isto o mediador é responsável por decidir qual é a agenda que deve ser seguida na mediação. Quando ocorre impasses, além do mediador poder mudar o tema, ele ainda pode se reunir separadamente com as partes para colocar a sua percepção do problema e trabalhar para a solução do problema com as partes, depois destas reuniões privadas o mediador reúne novamente com as partes em conjunto. $\mathrm{O}$ mediador tem como objetivo ainda no início da negociação incentivar a confiança 
entre as partes e dar passos de boa fé na negociação para que assim as partes possuam confiança durante a mediação. (p. 560)

Posteriormente à negociação o mediador deve começar a conduzir as partes para o acordo. Neste momento o mediador se reúne separadamente com as partes para identificar os objetivos e necessidades de cada um. Este objetivo é alcançado quando o mediador possui a confiança das partes. O mediador habilidoso guarda essas informações confidencialmente, porém, as utilizam para conseguir identificar pontos onde os objetivos e valores são semelhantes e, consequentemente, são os possíveis pontos de acordo. (p. 561)

A fase de implementação do acordo inicia-se após ele ser assinado e nesse período a sua implementação deve ser monitorada. $\mathrm{O}$ monitoramento, normalmente, é realizado pelo próprio mediador e quando o acordo é violado o mediador deve levar as partes para uma nova negociação, sendo que está nova negociação pode ser realizada pelo mesmo mediador ou por outro escolhido pelas partes. (p. 562)

A ONU também pode fornecer uma missão de paz para fazer o papel de observador ou para manter a ordem e a paz caso o Estado não possa realizar tal função. (p. 562)

Uma das vantagens das ONGs no monitoramento é que elas continuam a trabalhar dentro do Estado depois de realizar a mediação. Sendo assim, muitas vezes elas fazem o papel de monitorar o acordo e as partes as vêem como interessadas em que o acordo funcione, facilitando assim a mediação realizada por elas. (p. 562)

Além disso, visando a mudar o comportamento da população diante ao conflito, ou seja, tentando transformar os conflitos em políticos e não armados, as ONGs podem realizar o papel de educadoras. A educação e a formação desempenham papel importante durante a fase de transformação do conflito, podendo agir na sensibilização da sociedade perante as desigualdades do sistema, promovendo a compreensão, desenvolvendo as habilidades de defesa, democracia, resolução de conflitos, convivência com a sociedade e promover a cura e a reconciliação na base de implementação do acordo. A chave para esta atividade é a dimensão do preparo, ensino ou, de alguma forma, proporcionar a experiência de aprendizado para os outros a partir de uma posição de envolvimento direto de interação no conflito. (SAMPSON, 2007, p. 288) 


\subsection{Conclusão}

A mudança na natureza da guerra fez com que a mediação internacional sofresse severas modificações e que aspectos dela tivessem uma maior evidência. Como colocado anteriormente, os conflitos complexos trouxeram novas necessidades e desafios ao campo de resolução de conflitos. Outro fator considerável de mudança foi a entrada de novos atores na mediação internacional, o que será analisado mais profundamente no próximo capítulo.

Os conflitos complexos desenvolvem-se em um contexto de Estados falidos, nos quais instituições fracas ou inexistentes e a tensão entre autodeterminação e construção do Estado entram em choque constantemente, fazendo com que a legitimidade dos cidadãos fragmente-se e dirija-se a autoridades locais, tribais ou grupos organizados - sendo eles armados ou não, o que, em muitas situações, é somente estimulado pelos meios de coerção adotados pelo Estado, como é o caso do Aceh e de Moçambique. No contexto internacional e regional esses conflitos estão localizados no meio das tensões da globalização e sofrem fortíssimas influências da sua região, por exemplo, a formação da RENAMO em Moçambique e a influência dos demais conflitos da região dos Grandes Lagos no Burundi. Os conflitos ainda sofrem com o que podemos compreender como fatores externos ou internacionais, tais como fluxo de contrabando de comércio ilegal, armas e dinheiro. O fluxo de dinheiro decorrente de contrabando de recursos naturais, como o cotan e diamantes, financia os "senhores da guerra" nas suas lutas e controle de regiões.

A fragmentação da sociedade; a utilização de estratégia de guerrilha, do ataque a civis e armas leves; o desrespeito aos direitos humanos; a propagação do terror e do ódio ao "outro" em toda a sociedade faz com que a questão da perspectiva ganhe força na mediação, pois é extremamente necessário que ocorra a mudança de perspectiva para a sociedade conseguir realizar um processo de reconciliação e estabelecer mecanismo de resolução pacífica de conflito, visto que se deve considerar que o conflito não se restringe ao conflito armado, mas existe uma gama de conflitos sociais que devem ser resolvidos na sociedade e ajudam no desenvolvimento dela. 
A falta dos mecanismos de resolução de conflito é um dos grandes motivadores para o desencadeamento do conflito armado complexo, uma vez que as partes acreditam que a única via para conseguir alcançar as suas reivindicações é por meio da luta armada. Essa é outra perspectiva que deve mudar. Ou seja, não deve mudar somente a perspectiva em relação ao "outro", mas também o modo como a sociedade se organiza e como ela se enxerga.

Outro fator que ganha destaque na mediação é a cultura na definição do perfil das partes, no modo de organização da sociedade. (RICHMOND, 1998, pp. 707-712) O mediador precisa conhecer muito bem a cultura local para entender o comportamento das partes, para interpretar as mensagens provenientes das partes e para conseguir saber qual a melhor maneira de intervir no conflito. Além disso, a cultura pode fazer com que as partes se identifiquem com o mediador, construindo uma relação de confiança entre eles.

A relação de confiança pode derivar da identificação cultural entre as partes e o mediador, bem como de um relacionamento anterior, no entanto, ela é fundamental para a mediação, principalmente ao considerarmos a mediação de ONGs porque, muitas vezes, é da relação de confiança que provem a legitimidade desse tipo de mediador, além de tornar a mediação mais fácil devido à maior aceitação pelas partes às sugestões do mediador e uma maior abertura a negociação.

A incorporação de outros temas de outros temas na mediação, tal como a religião, é outra modificação. A religião foi incorporada no debate da mediação internacional, pois ela gera conflitos e influência o comportamento das partes, assim é necessário entende-la para compreender o conflito em muitas situações e as partes. A religião também pode contribuir ou não para a identificação entre as partes e o mediador. Além disso, deve-se considerar que em determinados conflitos a autoridade religiosa pode ser a única autoridade reconhecida nas comunidades; sendo assim, o mediador pode utilizar-se da rede religiosa para conseguir entrar nas comunidades afetadas e realizar os seus projetos e atividades, como foi o caso do conflito de Moçambique. (NATSIOS, 2007, p. 358)

A imparcialidade do mediador é um dos debates mais polêmicos da teoria de mediação. Muitos acreditam que a imparcialidade é fundamental, principalmente quando se trata de ONG, o qual deferia ser definido como um mediador puro, considerando que ela não possui o poder econômico e de coerção. 
(BERCOVITCH; SCHNEIDER, 2000, p. 148) No entanto, outros autores acreditam que a imparcialidade não é primordial desde que o mediador possua poderes para persuadir os mediados e conduzir a mediação. Já o terceiro grupo acredita que a escolha do mediador está mais ligada ao relacionamento anterior e as conexões de confiança entre as partes e o mediador do que a imparcialidade. (KLEIBOER, 1996, pp. 369-370)

A imparcialidade possui importância na mediação, todavia o mais importante é que as partes não considerem que uma delas esteja sendo privilegiada, caso isto ocorra o mediador pode perder os seus poderes frente às partes, ao considerar que quem dá o poder ao mediador é o mediado. Contudo, mesmo os autores que colocam a imparcialidade como fundamental defendem que o mediador deve influenciar a mediação para ser possível a mudança de perspectiva das partes e da sociedade. Também deve ficar claro que em situações de assimetria entre as partes o mediador deve intervir, podendo ser diretamente ou por meio de outro ator que faça a função de advogado da parte mais fraca, para o mediador não perder a sua legitimidade.

A influência do mediador no conflito é feito por meio do poder. Como colocado anteriormente neste capítulo, o poder não se resume ao poder coercitivo e econômico, mas possui outros aspectos que devem ser utilizados na mediação e podem ter um efeito mais acertado, principalmente ao consideramos os conflitos complexos, visto que o Estado está enfraquecido e com a sua infra-estrutura destruída pelo conflito, o que o torna um grande candidato para uma situação de dependência.

Ao considerar as características do conflito complexo apresentadas, a mediação não pode mais ser realizada de forma tradicional, burocratizada e com estratégia fixa. Ela deve ser flexível, criativa, adaptável às novas situações; inclusiva aos atores do conflito - sendo eles legítimos ou não. Principalmente ao considerar a falta de definição clara para os beligerantes; a mudança rápida do conflito; a falta de definição de quando se inicia e termina o conflito e a predominância de atores ilegítimos no conflito.

Sendo assim, a definição de uma diretriz de mediação é necessária. Considerando que o conflito complexo atinge todos os níveis da sociedade é primordial que a mediação englobe toda a sociedade, por isso, o modelo piramidal de Lederach é o mais indicado para esse tipo de conflito, pois, o modelo não se 
centra somente nos líderes e tomadores de decisão, como a mediação tradicional faz, mas engloba a toda a sociedade. (LEDERACH, 1997) O envolvimento de toda a sociedade é devido ao conflito atingir toda a sociedade diretamente ou indiretamente fazendo com que o processo de reconciliação seja necessário não somente entre os líderes mas em toda a sociedade. Outro fator para a mediação ser realizada de maneira ampla na sociedade é devido a falta de legitimidade do Estado, o qual não tem autoridade para falar em nome da sua população e fazer a implementação do acordo, visto que a legitimidade está fragmentada. (MÜNKLER, 2005, pp. 10-15) 


\section{3. \\ Organizações não-governamentais como mediadoras internacionais}

Como foi apresentado no capítulo anterior, as ONGs são atores cada vez mais presentes na mediação internacional, pois, diferindo-se dos demais atores da mediação tradicional, elas possuem especificidades que lhes permitem trabalhar em diferentes níveis da sociedade e utilizar ferramentas e mecanismos diferentes dos mediadores tradicionais. Sendo assim, este capítulo trata como as ONGs mediadoras trabalham. Dessa forma, é essencial que haja um rápido histórico da passagem das ONGs de um trabalho limitado a ajuda humanitária para um envolvimento mais político com a prevenção e resolução de conflitos.

Posteriormente, será tratado o relacionamento entre os Estados e as organizações não-governamentais, que se modificou consideravelmente nas últimas décadas; principalmente, devido à complexidade dos conflitos e ao maior custo político.

Alem disso, as ONGs não se limitaram a entrar no campo de prevenção e resolução de conflitos, mas também tornaram-se mediadoras principais dos conflitos. Elas começaram a coordenar a mediação em conflitos, principalmente aqueles que não despertam o interesse dos Estados, organizações internacionais e regionais. (AALL, 1996, p. 3)

Por último, serão analisadas as vantagens e limitações da mediação realizada por ONGs. Como todos os mediadores, as ONGs possuem vantagens e limitações que devem ser consideradas no momento da escolha do melhor mediador para o conflito. É fundamental ressaltar que como todos os mediadores possuem vantagens e limitações que devem ser analisadas no momento de escolha do mediador para cada conflito. Bem como nenhum mediador terá a capacidade de suprir todas as necessidades da mediação, sendo assim, é necessário que mais de um tipo ator trabalhe na mesma mediação. Esta situação pode ser fadada ao fracasso caso exista concorrência entre os mediadores e pode ser extremamente proveitosa com a coordenação dos mediadores. As ONGs podem fazer esse papel, além de fazer diversas contribuições para a mediação internacional nos conflitos complexos. Elas não precisam limitar-se ao papel de mediador de segunda via. 


\subsection{A entrada das organizações não-governamentais na mediação internacional}

As ONGs implementaram parte da resposta crítica internacional às crises que se desencadearam no período pós-Guerra Fria, oferecendo diferentes abordagens e habilidades fora da intervenção militar, a qual inclui a ajuda humanitária, medidas de prevenção e resolução de conflito, ajuda ao desenvolvimento e fortalecimento institucional. As ONGs são parte essencial para acompanhar de fora esta intervenção militar. Devido a sua baixa burocracia e flexibilidade, as ONGs são as primeiras a responderem às emergências complexas e por causa disso são impelidas a se envolver no conflito e nas suas operações de ajuda e alívio humanitário. (AALL, 1996, p. 3) (ver AALL, 2007, p. 477; CHIGAS, 2007, p. 561)

A mudança na natureza dos conflitos (ver tópico 2.1.2) e na ajuda humanitária demonstra a necessidade de examinar como as ONGs poderiam ser tão ou mais eficientes do que as Nações Unidas e as agências de governo na prevenção e resolução de conflitos. As atividades realizadas pelas ONGs podem ser divididas em duas grandes categorias: operações diretas, as quais incluem a ajuda humanitária e a resolução de conflitos, bem como a advocacia. (p. 3)

Devido ao maior número de lados visíveis no conflito com autoridade sobre grupos e territórios dentro do Estado tornou-se mais remota a possibilidade de sucesso da mediação realizada somente na mesa de negociação. $\mathrm{O}$ colapso da autoridade central e o surgimento de numerosos centros de poder são certamente uma das razões para os governantes voltarem-se para as ONGs com profundo enraizamento na comunidade e com acesso aos níveis basilares da sociedade, onde encontram-se autoridades tribais que podem funcionar como mediadores em conjunto com as ONGs entre as facções beligerantes. No caso das sociedades cujo governo desmoronou completamente, as ONGs e instituições religiosas podem ser as únicas fontes de autoridade que têm qualquer influência. (NATSIOS, 2007, p. 338) (ver CARMENT, 2003)

Sendo assim, ONGs religiosas que possuem fortes raízes com as instituições religiosas presentes em toda a sociedade em conflito podem utilizar-se dessa conexão como vantagem nos seus esforços de resolução do conflito. Obviamente, isto não se aplica, a situações em que a religião é um dos fatores 
desencadeadores do conflito ou que foi utilizada pelas elites para exacerbar o conflito. (pp. 345-346) A Comunidade Sant'Egidio, sendo uma ONG religiosa, utilizou-se do seu relacionamento profundo com o Vaticano e com as igrejas católicas moçambicanas, especialmente com o Bispo Gonçalves de Beira, o qual proporcionou a eles o acesso às facções beligerantes e à população desde o seu nível basilar.

As ONGs, que anteriormente possuíam como propósito fornecer alimentos, abrigo e suprimentos médicos durante as crises humanitárias, encontram-se cada vez mais pressionadas a prestarem outros serviços vitais e não existentes em sociedades de crise estabelecida, excedendo o papel que se destinaram a fazer originalmente em suas missões. A necessidade do envolvimento das ONGs em novas funções no pós-Guerra Fria decorre dos novos desafios que os conflitos complexos trazem para o campo da segurança e devido à nova relação Estado-ONGs, que se desenvolveu nesse período, pois em muitas situações as ONGs começaram a ocupar lugares anteriormente destinados ao Estado, sendo esse novo papel apoiado ou não pelos Estados. (p. 342)

Andrew S. Natsios afirma que ONGs cuja intervenção de socorro inclua um componente forte de desenvolvimento seriam mais eficazes na resolução de conflito do que aquelas focadas na logística e distribuição de commodities. Pois, o primeiro tipo já tenderia a considerar as consequências a longo prazo de suas ações e entenderiam melhor as complexidades do conflitos. (p. 342)

O súbito colapso da rede social composto pela elite tradicional, a qual está morta, traumatizada, no exílio ou em campo de refugiados, e o surgimento de "senhores da guerra" para tomar o seu papel reduz a utilidade da diplomacia

tradicional como ferramenta de resolução de conflitos. Em decorrência, o interesse pelas ONGs reflete a busca de alguma instituição viável para influenciar as situações de emergências complexas. (p. 339) As ONGs, além de poderem estar inseridas nas sociedades e serem as únicas instituições de fora do conflito capazes de influenciá-lo. Também são as únicas capazes de dialogar com grupos ilegítimos, devido o alto custo político desta atitude. (ver MITCHELL, 1992, p. 277)

\subsection{O relacionamento das organizações não-governamentais e os} Estados 
Em decorrência da situação apresentada, a relação Estado-ONGs também sofreu severas modificações. A relação Estado-ONGs aproximou-se levando, em muitas situações, a divisão da resposta internacional. Os desafios apresentados ao Estado e as ONGs tornaram-se mais intensos, devido à natureza das emergências internacionais e a relação entre ambos, a qual tornou-se mais incerta. (COOPER; HOCKING, 2000, pp. 361-363)

Anteriormente os atores estatais e não-estatais eram entendidos como habitantes de diferentes ambientes, trabalhando com regras, livros, ocupações e escala hierárquica diferente na política internacional. Contudo, a partir dos desafios no cenário internacional percebeu-se a necessidade de uma maior integração pautada por uma abordagem mais flexível, diferenciado do princípio estado-centrico $^{16}$. A relação Estado-ONGs é marcada, na maioria das vezes, por uma relação de sinergia, ou seja, eles apoiavam-se em uma cesta de questões, as quais foram previamente selecionadas item a item. A estrutura relacional entre as duas instituições teve um considerável impulso devido a mudanças mais amplas nos governos, as quais possibilitaram uma intervenção mais viável e atraente entre eles. (p. 367)

Em algumas circunstâncias, as ONGs atuam como agentes sub-contatados pelo Estado, ou seja, recebem o apoio ou patrocínio do Estado para atuarem como facilitadoras do trabalho estatal ou, como é o caso nesta dissertação, como mediadora principal do conflito. (p. 367) O Conflict Management Initiative é financiado principalmente por instituições governamentais, o que levanta o questionamento do seu relacionamento com os governos e se ela seria independente aos interesses dos seus financiadores.

É fundamental ressaltar que, em nenhum momento na relação EstadoONGs, o Estado fica obsoleto na sua função de tratar dos desafios internacionais; contudo, em circunstâncias específicas, eles precisam ou preferem utilizar as ONGs para responder às emergências. Ao mesmo tempo, as ONGs não foram e não são passivas no processo, elas perceberam que precisam incorporar novos elementos nas suas políticas para conseguirem responder às emergências

\footnotetext{
${ }^{16} \mathrm{Na}$ abordagem estado-centrico as ONGs e o Estado não possuiriam nenhuma interação, sendo o papel das ONGs limitados, no máximo, a uma importância secundária em relação aos governos nacionais. Qualquer que seja a atividade das ONGs elas não se relacionam com o mundo da diplomacia, a qual se caracteriza pela forte presença de uma diplomacia oficial do governo. (COOPER; HOCKING, 2000, p. 363).
} 
internacionais diferenciadas provenientes dos conflitos complexos e desejaram envolver-se politicamente nos novos desafios. Deve-se lembrar ainda que, quando se fala das ONGs, trata-se de um universo tão diverso que é impossível entendêlas da mesma forma. (p. 367-368)

Os conflitos complexos são provenientes de mudanças dentro do sistema internacional no pós-Guerra Fria e de mudanças que vinham ocorrendo na constituição do Estado-nação, como a formação de Estados sem capacidade e instituições estabelecidas para conseguir realizar o complexo processo de construção estatal. O que resultou em mudanças significativas na relação EstadoONGs, como descrita anteriormente, e em toda a resposta internacional aos conflitos. Não é mais possível realizar a mediação tradicional, desenvolvida para enfrentar conflitos baseados nos princípios Vestfáliano, em conflitos complexos. (p. 368)

\subsection{Organizações não-governamentais no papel de mediadoras principais}

Devido à complicação e à falta de centralidade dos conflitos complexos (ver CARMENT, 2003; BUTLER, p. 58; ZARTMAN; TOUVAL, 2007, p. 445), não é possível tratá-los de forma setorial como era feito anteriormente, ou seja, as ONGs não conseguem mais se envolver somente com refugiados ou com a missão humanitária, elas precisam tratar do conflito como um todo. Sendo assim, muitas vezes a resposta efetiva aos conflitos complexos necessita de que as missões das ONGs abranjam muito mais do que tradicionalmente estava previsto, o que consistia na ajuda humanitária. Em decorrência, Vivian Lowery Derryck coloca que certas condições devem estar presentes antes das ONGs se envolverem em atividades de gestão de conflitos: devem conhecer o país e as instituições regionais envolvidas no esforço de solução do conflito, precisam ter parceiros no local do conflito, seus membros devem possuir um bom conhecimento do conflito e habilidade de mediação, e seu pessoal de campo deve compreender os riscos pessoais que estão assumindo. (AALL, 1996, p. 19)

Nos últimos anos, algumas ONGs dedicadas à prevenção e à resolução de conflitos têm adotado algumas das técnicas de ONGs especialistas em direitos humanos, a fim de alertar os tomadores de decisão mais influentes das condições que podem provocar ou promover a disseminação ou surtos de violência. Elas 
tentam chamar a atenção para as condições determinantes ou alterações das circunstâncias que afetam a paz e os conflitos através de inquéritos e relatório sobre o terreno do conflito. (AALL, 2007, pp. 488-489)

A promoção da capacitação na sociedade em conflito pode ser realizada eficazmente pelas ONGs. Pois, a capacitação pode assumir a forma de incentivos ao crescimento da sociedade civil, à construção de capacidades locais para melhorar a paz pelas competências da mediação e negociação, formando funcionários locais na gestão e resolução conflitos, os quais são normais em qualquer sociedade, reforçar o apoio ao Estado de direito e instituições deliberativas e trabalhando com autoridades educacionais e outras para a reforma educacional. No exercício destas funções, as ONGs irão implementar todos os poderes informacional, perito e legitimo que já foram debatidos no capítulo anterior. (p. 489). Fazendo assim os lados modificarem a sua ideia pela atração e não se utilizando somente da coerção.

Em algumas situações, as ONGs atuam como a mediadora principal no desenvolvimento de acordos, ajudando a implementar os acordos, construindo o apoio nos processos de paz na comunidade internacional, e promovendo mudanças políticas para assim criar um melhor ambiente de paz e de transformação política. (CHIGAS, 2007, pp. 555-556) Porém, as ONGs não se limitam a essas atividades, mas também participam das atividades que os mediadores mais poderosos não participam, tal como: colocar temas e os conflitos na agenda internacional e na construção de capacidades de mudança dentro do conflito. (ver SAMPSON, pp. 280-288)

Diane Chigas coloca que ocorrerem três diferentes níveis de intervenção, os quais foram apresentados no capítulo anterior, sendo que em cada um deles o mediador trabalha com uma classe diferente de participantes e, geralmente, estão envolvidos com diferentes tipos de atividades objetivando diferentes resultados. O nível um e meio é no qual trabalham as ONGs que realizam o papel de mediador principal. A ação das ONGs neste nível pode ser divida em dois tipos, sendo o primeiro com maior protagonismo. ${ }^{17}$

\footnotetext{
${ }^{17}$ Esta tipologia de níveis foi concebida para destacar uma das características principais dos conflitos intratáveis, que é a incapacidade de o mediador ou qualquer ator disposto a intervir no conflito atuar em somente um nível e visando somente em assentamentos ou acordos. (CHIGAS, 2007, p. 555)
} 
No primeiro, é a mediação direta, em que o intermediário da ONG age como mediador ou conciliador direto entre as partes em conflito, por meio da facilitação da comunicação ou pelo fornecimento de informações, tentando a solução para o conflito ou de questões específicas em litígio. Como mediadora, a ONG está livre para iniciar discussões, facilitar a comunicação e explorar novas ideias por não estar ligada a nenhum governo ou organização internacional. Um exemplo desse tipo de mediação é o que aconteceu em Moçambique pela Comunidade de Sant'Egídio e será abordado mais profundamente ao longo do próximo. É importante ressaltar que, sem o envolvimento da Comunidade de Sant'Egídio, Moçambique poderia terminar com o pouco que restou do país ameaçando a estabilidade da região. A Comunidade impediu que o conflito fosse esquecido no cenário internacional. (pp. 555-557)

No segundo é o papel de assessoramento no qual a ONG age como um facilitador de diálogo informal e imparcial para a resolução de problemas entre os negociadores e os tomadores de decisão, tentando ajudar as partes na análise, com atitudes antagônicas e às questões na sua relação. Este tipo de intervenção é frequentemente desempenhada pelas ONGs. Neste modelo, as pessoas chaves que compõem a mediação são trazidas para acompanhar as negociações pelas suas capacidades pessoais e não por serem representantes de governos. As reuniões são fechadas ao público e possuem caráter não vinculante, sendo que os representantes das partes partilham de suas percepções e preocupações, enfocando os interesses e necessidades básicas que sustentam as suas posições, analisando conjuntamente as questões subjacentes e seus relacionamentos e desenvolvendo ideias para as suas resoluções. Essas oficinas são destinadas a promover a relação e confiança entre as linhas em conflito, desenvolvendo caminhos de comunicação e explorando as opções que podem satisfazer os interesses e necessidades de ambos os lados. Elas servem ainda para mudar as percepções e trazer novas informações para o debate. (p. 555-557) Foi este o papel que o Center for Conflict Resolution e do Search for Common Ground desempenharam no conflito do Burundi, sendo esta uma mediação de segunda via. (ver JONES, 1999, p. 59)

O chamado "Track Two" (o segundo nível) também inclui o modelo de "paz pública", o qual pretende envolver os representantes das partes em conflito em um diálogo conduzido no método de cinco fases, nas quais são tomadas medidas no campo político com o objetivo de mudar percepções e estereótipos 
para criar um senso de que a paz pode ser possível e para o desenvolvimento dos seus compatriotas. (pp. 557-559)

O terceiro nível de atuação das ONGs é aquele que tem registrado o maior crescimento desde o início da década de 90, consistindo em temas como: identidade, representação, governança, segurança humana e questões que têm assumido maior importância na agenda da paz. A premissa desse nível é que a paz pode e deve ser construída de baixo para cima, bem como de cima para baixo. Dessa forma, as intervenções realizadas com base no nível três possuem como principal objetivo a reconstrução do "capital social" nas sociedades que foram atingidas pelo conflito, ou seja, o objetivo das ONGs não é somente fornecer assistência à reconstrução rápida e eficaz, mas também criar formas alternativas de organização que promovam a cooperação e reconstrução. (pp. 559-561)

Apesar de as ONGs atuarem em todos os três níveis explicitados aqui, o objetivo desta dissertação é aprofundar no primeiro nível de atuação, ou melhor, o nível "um e meio", pois, nos demais dois níveis, as ONGs estão limitando o seu papel na mediação, ou seja, existe outro mediador principal o qual, normalmente, é o mediador tradicional, um Estado ou uma organização regional ou Internacional, e as ONGs cumprem o papel de auxiliar a mediação, já que conseguem lidar com todos os níveis do conflito, como foi colocado no capítulo anterior. Apesar desse papel secundário ser importante na mediação e ser o mais comumente realizado pelas ONGs, não será sobre ele que esta dissertação irá abordar principalmente. Esta dissertação aborda a ONG no papel de mediador principal e, portanto, no nível um e meio, sendo que não desconsideramos a participação e a importância de outros mediadores no conflito e auxiliando a ONG, no entanto, ela é a principal mediadora.

\subsection{As vantagens das organizações não-governamentais na mediação internacional}

Os conflitos complexos geraram a necessidade da mediação internacional adaptar-se às novas necessidades de respostas impostas por eles ao cenário internacional. (ver tópico 2.1.3) Frente a esta necessidade, as ONGs possuem vantagens e oportunidades na mediação frente a Estados, organizações internacionais e regionais, que serão explicitadas nesta sessão. 
A primeira vantagem das ONGs é a rapidez com a qual elas podem responder ao conflito e impedir que ocorra uma nova escalação de violência, o que é necessário para a realização da mediação, pois, as ONGs possuem processo de decisão e burocracia menos complexas em comparação com Estados e organizações internacionais, permitindo, assim, mobilizar recursos, que podem ser provenientes tanto da sociedade civil como dos Estados, e agir com maior rapidez. Dessa forma, as ONGs mediadoras podem se envolver na fase inicial do processo, interagindo com as partes para prepará-las para as negociações de paz. Essa vantagem é importante devido à necessidade do mediador ser flexível e adaptável ao contexto do conflito, esta importância ganha maior força quando consideramos os conflitos complexos e as suas características. Então, nesse caso, as ONGs não se mantêm engessadas pela burocracia e normas pré-estabelecidas como os Estados, organizações internacionais e regionais. (LANZ; SGUAITAMATTI, 2009, p. 5) A baixa burocracia e flexibilidade das ONGs não é somente útil para uma resposta mais rápida do conflito, mas também para adaptar a mediação aos acontecimentos no conflito. (ver AGGESTAM, 2003, p. 17) Como colocado no capítulo anterior, as forças nos conflitos complexos são extremamente fluidas, podendo mudar de autoridade rapidamente, além dos acontecimentos no conflito serem volúveis precisando da adaptação constante do mediador. (ver NATSIOS, 2007, p. 341)

O caráter não oficial das ONGs e a sua flexibilidade frente aos outros mediadores é outra vantagem delas. (AGGESTAM, 2003, p. 17) Portanto, Estados e organizações internacionais são limitadas na intervenção no conflito devido ao seu caráter oficial. (CREEKMORE; TAUBEE, 2003, p. 158) Além disso, a intervenção é um processo politicamente arriscado devido aos Estados considerarem a mediação como interferência em assuntos internos, ou seja, uma violação a sua soberania. Devido a isto as ONGs enfrentam menos restrições políticas, apesar de possuírem procedimentos formais, e como resultado elas possuem o perfil de risco diferenciado. Devido a esta característica, as ONGs podem envolver-se em zonas sensíveis e dialogar com atores considerados "terroristas" ou não reconhecidos pelo Estado, ou seja, ilegítimos que atuam sem correr o risco do efeito de legitimação, já tratado no capítulo anterior. (CHIGAS, 2007, p. 561) Além disso, as ONGs conseguem realizar o seu trabalho nas missões com menos exposição. (LANZ; SGUAITAMATTI, 2009, p. 5) 
No capítulo anterior, os conflitos complexos foram também caracterizados pelo desequilíbrio de poder e legitimidade internacional entre os beligerantes. (ver JONES, 1999, p. 59) Nessas situações assimétricas, Estados, organizações internacionais e regionais possuem dificuldade para intervir e conseguir engajar atores não estatais armados, mesmo que esse envolvimento seja fundamental para prevenir ou reduzir a violência. Enquanto isso, como já foi colocado, as ONGs enfrentam menos obstáculos ao se envolver com grupos armados não estatais, os quais muitos consideram como "terroristas" ou "párias". ONGs mediadoras, muitas vezes, conseguem ganhar a confiança de tal grupo e podem contribuir para a construção de sua vontade em se envolver nas negociações de paz. Ao mesmo tempo, as ONGs podem ser entendidas como menos ameaçadoras para os Estado como o seu engajamento não é entendido como uma forma de conferir legitimidade a seus adversários contrariamente o que acontece com Estados e organizações internacionais e regionais. (LANZ; SGUAITAMATTI, 2009, pp. 56) Como colocado no capítulo anterior, o envolvimento de todos os grupos significantes na mediação, bem como de toda a sociedade, especialmente ao considerar conflitos complexos, é fundamental para a resolução real do conflito. No tipo de conflito aqui trabalhado não adianta a mediação envolver somente os líderes legítimos, pois caso isto aconteça o acordo final será vazio e impossível de implementar. Pois, a real autoridade do conflito está sobre as mãos de líderes ilegítimos, (ver MÜNKLER, 2004, pp. 11-13) e porque toda a sociedade está envolvida no conflito, sendo assim, o processo de cura e reconciliação tem que envolver toda a sociedade. (ver NATSION, 2007, p. 358)

A mediação internacional necessita de conhecimento técnico, competência e apoio local para a sua realização com sucesso e essa é uma das vantagens das ONGs em relação a Estados, organizações internacionais e regionais, pois, normalmente, elas dispõem de especialistas em tópicos e regionais que podem fazer consultoria ou integrar o grupo de mediadores. ONGs locais, em particular, têm um amplo conhecimento sobre o conflito, seus atores e as questões chaves. Além disso, as ONGs internacionais podem pedir um assessoramento as ONGs locais, as quais estão mais próximas ao conflito, a partir da sua rede de relacionamento. As ONGs ainda podem contribuir com conhecimentos no processo baseados em suas experiências anteriores e a concepção dos processos de diálogo. (p. 6) Os conflitos complexos possuem causas profundas para o seu 
desencadeamento, as quais precisam ser tratadas no período da mediação, pois somente desta forma que a mediação será bem-sucedida. Sendo assim, é necessário que o estudo sobre o conflito seja profundo, caso contrário, a mediação pode agravar o conflito.

Durante o processo de negociação de paz, as partes em conflito empreendem riscos como exigir mudanças fundamentais de mentalidade e consumir a sua fonte de poder. Nessas situações, as ONGs podem proporcionar um ambiente confiável, discreto e de baixa pressão, no qual as partes em conflito constroem um relacionamento e sentem-se seguros para testar ideias, sabendo que posteriormente podem negá-las. Essa possibilidade é devido à motivação ligada a objetivos geopolíticos e a não-utilização de meios coercitivos, como foi observado no capítulo anterior. Sendo assim, podemos perceber que até mesmo a falta do poder coercitivo pode ser uma vantagem para as ONGs. (KELMAN,2000, p. 275) A falta de poder coercitivo e de barganha por parte das ONGs fazem com que as partes sintam-se menos pressionados durante a mediação, o que primeiramente é interessante para o desenvolvimento da mediação. Contudo, caso uma das partes não deseje a mediação ou se o mediador precisar ser mais firme com as partes, para que mudanças reais aconteçam, as ONGs têm que estar conscientes da falta desses dois tipos de poder. Sendo que, caso seja extremamente necessários, eles devem buscar o auxilio de Estados e organizações internacionais, principalmente. (ver LANZ; SGUAITAMATTI, 2009, pp. 9-10)

A atuação das ONGs é particularmente baseada em valores; devido a isto seu trabalho pode ser percebido como uma mediação não somente focada na realização do acordo entre as partes, mas também em transformações democráticas da sociedade em conflito, na qual futuros litígios serão resolvidos pacificamente, ou seja, elas estão preocupadas com a construção de mecanismos para a resolução dos conflitos na sociedade. Sendo assim, as ONGs podem promover uma verdadeira cultura da paz, o que é fundamental para impedir novos conflitos, devido a sua motivação honesta, sua persuasão, paixão pela paz e insistência no tratamento justo dos beligerantes no âmbito do processo de mediação. Além disso, as ONGs podem identificar, mobilizar e capacitar agentes de paz numa sociedade lançando as bases para uma paz sustentável. (LANZ; SGUAITAMATTI, 2009, pp. 6-7) A capacidade das ONGs em aplicar programas de reconciliação e de estar presente em todos os níveis do conflito é fundamental 
para o processo de mediação e obtenção de resultados favoráveis e sustentáveis, principalmente quando consideramos os conflitos complexos. A existência de mecanismos de resolução de conflito na sociedade é primordial para não ocorrer a recorrência do conflito, visto que o conflito é normal, necessário e até mesmo ajuda no desenvolvimento da sociedade. (ver SAMPSON, 2007, p. 288)

O profundo conhecimento do contexto local e da cultura é indispensável para a realização da mediação e muitas ONGs, principalmente as locais, estão envolvidas no contexto há muitos anos, o que proporciona a elas e a sua rede de contatos um alto grau de conhecimento. (CHIGAS, 2007, p. 562) Dessa forma, elas estão familiarizadas com a linguagem e práticas culturais nos países em conflito, e se relacionam com uma grande gama de atores sociais. (NATSIOS, 2007, pp. 343-344) A proximidade das ONGs com a sociedade por meio de trabalhos anteriores ou da rede de conhecimento é fundamental para o seu conhecimento sobre a cultura, valores e costumes locais, o que é imprescindível no momento da mediação. Pois, o mediador deve conhecer profundamente todos os aspectos da sociedade em conflito para conseguir interpretar as partes e comunicar-se com elas. (ver RICHMOND, 1998, p. 709)

Devido a isso, as ONGs podem conseguir ganhar a confiança das partes em conflito, facilitando um processo efetivo de mediação. $\mathrm{O}$ conhecimento do contexto cultural e local é importante também para o mediador conseguir produzir uma relação profunda e de confiança com as partes, pois, como colocado no segundo capítulo, as partes estarão mais propiciais a aceitar a mediação caso o mediador possua certo nível de identificação com elas, seja por similaridades culturais, religiosas, conhecimento anterior, ou qualquer outro tipo de fator. $\mathrm{O}$ desenvolvimento de um relacionamento anterior à mediação também é fundamental, pois é a partir dele que a ONG pode conseguir a sua legitimação como mediador. (ver KLEIBOER, 1996, p. 369)

As ONGs atuam tanto como mediadores principais como trabalhando no apoio à população mais ampla da sociedade em conflito, como também na ligação entre esses processos e a mediação oficial. Isso é tanto ou mais importante no processo de implementação de um processo de paz. ONGs, principalmente as que estão presente localmente, estão bem adaptadas ao engajamento com atores locais para a construção de círculos de paz. (CHIGAS, 2007, p. 562) Elas também são qualificadas na promoção de um diálogo entre os líderes do nível médio, que 
podem utilizar a sua influência para convencer as partes em conflitos para a negociação ou implementação do processo de paz. Outro papel importante das ONGs nessa área é a vinculação dos processos de diálogo com entidades civis para as negociais oficiais de paz. O acompanhamento da implementação do acordo de paz após a negociação tenha terminado é um dos papéis cruciais desempenhados pelas ONGs. (LANZ; SGUAITAMATTI, 2009, p. 8) Esse envolvimento em todos os níveis do conflito é extremamente necessário para a mediação internacional atualmente, como mostra o modelo piramidal no segundo capítulo. (ver LEDERACH, 1997)

A mediação normalmente é realizada por uma elite política e militar que decide o futuro de um país. Para contrair a natureza exclusiva da mediação é essencial que o mediador busque incluir os interesses de um vasto leque de agentes públicos. As ONGs, como membros civis da sociedade, estão em melhores condições para chegar a civis interessados na negociação e que tradicionalmente eram excluídos, elevando a perspectiva de suportar e fomentar a diversidade das negociações oficiais de paz. ONGs também podem ser bem posicionadas para promover temas sensíveis, como gênero, nas negociações. A introdução dos interesses civis na negociação e a realização de negociações em diversos níveis são fundamentais para a realização do modelo piramidal de mediação e como podemos perceber as ONGs possuem mais qualidades para implementar esse modelo, que é o mais recomendável para a solução de conflitos complexos. (pp. 7-8)

A dificuldade de resolução e, consequentemente, o envolvimento de mediadores formais em conflitos complexos, nos quais as partes lutam entre si há décadas, ocasionando um alto escalamento do conflito, faz com que um processo informal e confidencial, o qual pode acontecer antes ou durante o processo de paz, seja necessário. Nessas situações, as ONGs estão próximas ao conflito, permitindo com isso tirar vantagens dessa proximidade com os atores principais para testar as opções, alternativas e ideias antes das partes em conflito comprometerem-se a entrar em uma negociação formal. As ONGs possuem uma maior possibilidade de manobra devido a sua informalidade, a qual é um importante atributo para a atuação do intermediário em processos informais. As ONGs realizam oficinas e projetos entre as partes em conflito com o objetivo de mudar a perspectiva das partes em relação ao "outro”. (AALL, 2007, pp. 481-482) 
Diana Chigas concorda com os pontos apontados pelo relatório quanto às vantagens das ONGs na mediação internacional, tais como a maior flexibilidade a qual possibilita as ONGs relacionarem-se e levarem à mesa de negociação atores considerados ilegítimos; a possibilidade de realizar reuniões informais, nas quais as partes podem testar ideias, que podem ser negadas posteriormente; a resposta rápida das ONGs a possibilidade de um conflito; o conhecimento das ONGs a cultura e práticas locais; e a sua rede de conhecimento. Ela ainda acrescenta que devido ao menor custo político das ONGs em relação a Estados e organizações internacionais e regionais, elas possuem menos resistência e abre espaço para a exploração de possíveis negociações, quando as partes ainda estão empenhadas em ações unilaterais. No nível três de atividades as ONGs fornecem frequentemente um único espaço seguro onde as partes podem satisfazer as suas necessidades. As ONGs também possuem a capacidade de mobilizar e fornecer especialistas que vão desde a justiça transicional à política econômica, passando por combate à corrupção e ao regresso dos refugiados. (CHIGAS, 2007, 561)

As ONGs ainda são capazes de lidar com as partes mais subjetivas, sóciopsicológicas do conflito, enquanto a diplomacia dos atores oficiais não consegue. Pois, os instrumentos tradicionais de negociação, mediação e gestão de conflitos não são adequados para abordar estes aspectos, o que é um problema para a solução eficaz dos conflitos complexos, porque, como colocamos no capítulo anterior, esse conflitos possuem como principal característica a propagação do horror; sendo assim, é essencial a mudança da percepção das partes em conflito como de toda a sociedade. As ONGs tendem a conseguir a se adaptar para trabalhar com recursos baseados em questões como a proteção a identidade e as necessidades humanas. As questões de identidade, sobrevivência e demonização do outro exigem processo que trabalhem diretamente com o objetivo de alterar o relacionamento humano e lidar com as percepções, confiança e receios que são mantidos anteriormente. (AYRES, 1997, p. 423)

Os mais relevantes impactos das ONGs podem ser agrupados em quatro categorias. A primeira é a mudança de atitude psicológica das partes. A mudança mais comumente observada no resultado da gestão de conflitos realizada por ONGs é a quebra dos estereótipos negativos e generalizações de cada um dos lados. Os participantes aprendem que existe uma diversidade de pontos de vistas em ambos os lados, incluindo visões que atravessam as linhas de conflito e 
identificam a "coligação de parceiros" do outro lado, o que pode funcionar para abrir uma linha de negociação, ou seja, pode-se identificar pensamentos comuns entre as partes, podendo ser utilizado para iniciar as negociações. O processo de diálogo das ONGs também pode ajudar a transformar a percepção do conflito, pois abre espaço para a negociação, facilitando a compreensão mútua e a aceitação da preocupação sobre a sobrevivência e identidade transformando a ideia de ganho/perda e /ou modificando a definição do conflito. (CHIGAS, 2007, pp. 563-566)

A segunda categoria é a melhor comunicação e relações entre as linhas de conflito. Percepções negativas, desconfiança e confronto entre as partes são perpetuadas pela falta de comunicação, em alguns casos até devido barreiras físicas. As ONGs têm contribuído significativamente para a abertura de canais de comunicação entre as partes, que, caso o contrário, seria difícil de encontrá-lo para satisfazer ou realizar qualquer contato, melhorando assim a comunicação em todas as linhas do conflito. Isso é especialmente importante em conflitos altamente escalonados, no quais a violência e as tensões agravaram-se e geralmente levaram à interrupção das linhas de comunicação, tanto da elite como dos vários níveis da sociedade. (pp. 563-566)

A terceira categoria é o desenvolvimento de novas opções para diminuir a polarização ou concorrência das soluções. Processos realizados pelas ONGs podem gerar ideias criativas para a solução dos problemas que ao podem ser suscitados em negociações realizadas pelos atores oficiais, bem como um quadro de pessoas com experiência no trabalho e capazes de conduzir as negociações. (p. 563-566)

A quarta categoria é a contribuição para a mudança da institucionalização dos conflitos. Essa categoria pode ser divida em outras três subcategorias. A primeira é a mudança na dinâmica do conflito, tendo impacto na estrutura do conflito de forma que pode facilitar a transformação da sociabilidade, reforçando forças pró-negociação, mudando discursos públicos e a opinião sobre o conflito, a construção da paz e de círculos eleitorais em todos os níveis da sociedade. A segunda categoria é o reforço nas forças de moderação, pois nos conflitos intratáveis é difícil os moderadores de um dos lados terem voz política. Normalmente, eles são orientados para o exílio e sofrem intimidações, os processos não oficiais são capazes de dar voz aos silenciados ou marginalizados, 
mudando a perspectiva no discurso político. A terceira é a rede social, a qual pode ser considerada como a infra-estrutura para a paz, porque é importante construir um ambiente político, eleitoral e capaz de apoiar e sustentar os esforços pacificadores do conflito, quando inevitáveis retrocessos ocorrem. (p. 567-590)

\subsection{As limitações das organizações não-governamentais na mediação internacional}

A principal limitação destacada pelos teóricos da mediação internacional, como Pamela Aall, é a falta de poder das ONGs perante a mediação. Primeiramente, destaca-se, como abordado no segundo capítulo, que o conceito de poder é mais amplo do que o poder militar e econômico, decorrendo então que as ONGs possuem poderes consideráveis na mediação internacional. (ver AALL, 2007, p. 486) Existe uma dupla visão sobre a falta desses poderes em relação às ONGs. A primeira visão defende que as ONGs atuantes na mediação internacional não têm recursos ou autoridade para influenciar as partes, que não estão prontas ou dispostas a iniciar a negociação, consequentemente tendem a serem manipuladas pelas partes para os seus próprios objetivos estratégicos. (CHIGAS, 2007, p. 562)

A segunda visão aponta que, pela falta dos dois poderes, as ONGs podem potencializar as suas atuações na mediação internacional. Pois, a baixa pressão ocasionada pela falta desses poderes permite as ONGs realizarem mediações que necessitem de baixa pressão militar e política. $\mathrm{O}$ mesmo grupo acredita que a mediação é baseada em confiança, e considera a falta dos dois tipos de poder uma possibilidade do mediador tratar de modo justo as partes. Sendo que estas poderão ter mais confiança perante o mediador, visto que ele não poderá utilizar-se da coesão militar ou econômica para atingir o resultado desejado por ele na mediação. (LANZ; SGUAITAMATTI, 2009, pp. 9-10)

A visão positiva da falta do poder militar e econômico por parte das ONGs defende que devido a esta situação as partes não vão abandonar o acordo após a retirada dos incentivos por parte do mediador. Não obstante as potencialidades apontadas pela visão positiva da falta dos dois poderes para as ONGs, elas devem conscientizar-se de que não possuem os dois poderes, os quais permitiriam a elas agir mais robustamente no caso da falta de amadurecimento do conflito ou de 
animosidade entre as partes. No entanto, a ONG pode solicitar auxilio das organizações internacionais, regionais e Estados caso os poderes militar e econômico sejam imprescindíveis à mediação. (pp. 9-10)

As ONGs também são limitadas pelos seus fatores condicionantes - o ambiente político, a agenda dos doadores e a linha de tempo, e as estratégias e prioridades da própria $\mathrm{ONG}$ - que limitam a amplitude de alcance e o impacto causado por elas no conflito. Em decorrência, muitos trabalhos das ONGs são pequenos e localizados e os seus impactos dependem fortemente da participação pessoal e experiência de diferentes tipos de relacionamentos com o outro. (KAYNE, 2001, p. 68)

Outra limitação das ONGs consiste sobre diversidade considerável delas trabalhando em diferentes campos o que leva ao questionamento da capacidade delas em atuar em campos específicos, como a mediação internacional. Chigas destaca fatores ligados à multiplicidade e despreparo das ONGs em atuar em determinadas áreas. Determinadas ONGs não têm habilidade e competência para operar em campos extremamente profissionais, pois faltam-lhes pensamentos estratégicos e programa específico, limitando o campo de ação das ONGs (p. 555) A mediação internacional possuí diversas peculiaridades, exigências e necessidades que a ONG precisa estar preparada para suprir. A mediação internacional exige que a ONG tenha membros treinados e experientes em resolução de conflito, um suporte financeiro e físico mínimo, o qual possibilite o deslocamento dos seus membros até o local do conflito e dos participantes da mediação para fora do conflito, caso necessário. Além disso, a ONG precisa ter a capacidade de se inserir na sociedade para conseguir envolver-se em todos os níveis sociais e assim ser capazes de fazer a mediação baseada no modelo piramidal. (ver LEDERACH, 1997)

Outra limitação das ONGs situa-se na sua contribuição frente às forças políticas que elas desejam modificar. Os projetos realizados pelas ONGs - como projetos de infra-estrutura econômica e para o desenvolvimento, operações objetivando a manutenção da cooperação e do desenvolvimento do sentimento de comunhão com base em interesses compartilhados - podem não conduzir objetivamente para as mudanças de percepção, estereótipos e na imagem do inimigo, como é o desejo das ONGs. (CHIGAS, 2007, p. 570) 
As ONGs têm como uma das suas principais vantagens a capacidade de reunir diferentes pessoas e grupos em um ambiente informal e despolitizado, contudo, se a capacidade delas não for bem administrada, as ONGs afastando-se do ambiente político com o qual estão dialogando e não conseguem atingir os seus objetivos macros com os projetos planejados. (p. 571) As ONGs precisam ter consciência dos objetivos que elas desejam alcançar com cada projeto e os reais impactos destes na sociedade. É inadmissível que as ONGs, que querem trabalhar com mediação internacional e com a implementação do acordo de paz, dois campos de ação extremamente delicados, não tenham a real dimensão dos impactos dos seus projetos. (ver KELMAN, 1993, pp. 236-238)

A falta de coordenação no trabalho das ONGs é uma grande limitação, pois as ONGs precisam manter o diálogo e a cooperação constantemente, visto que as partes ao recebem influências contraditórias perdem a confiança no mediador, deixando o processo de mediação confuso, dificultando o trabalho realizado pelas ONGs. As partes são influenciadas por novas informações que recebem sobre experiências de outros conflitos, o que possibilita iniciativas e aceitações de novas atitudes perante o "outro" e novas relações. Em contrapartida, elas são sujeitas à pressão de suas comunidades para agir em relação ao "outro" de acordo com as atitudes e normas vigentes, o que os impulsiona ao questionamento sobre as novas atitudes e consequentemente ao não cumprimento delas. Resultando na permanência da posição dos grupos, caso não ocorra um esforço freqüente de diálogo e da cooperação por parte do mediador. (p. 571)

A competição entre os projetos das diversas ONGs, que trabalham em campo, agrava seriamente a falta de coordenação entre elas. Isso porque a falta de uma política compartilhada de ação no conflito e da coordenação dos projetos, que vão ser realizados em cada área, podem levar à concorrência entre os projetos e a problemas morais e políticos. (NATSIOS, 2007, pp. 344-345) A limitação descrita não é especifica das ONGs, mas inclui todos os tipos de mediadores. Todos os tipos de mediadores precisam coordenar as suas atividades com os demais atores atuantes no conflito, e caso tenha mais de um mediador entre si. (ver EVANSKENT; BLEIKER, 2003, pp. 110-112)

A diversidade das ONGs pode ser uma limitação quando elas não saibam se comunicar e cooperar, pois, a diversidade de ONGs permite que as partes mudem o mediador por não gostarem das atitudes dele durante o processo. A mudança do 
mediador é habitual, caso o processo não esteja sendo bem desenvolvido ou se uma das partes encontra-se insatisfeita com o mediador ou com o processo. Todavia, as partes não podem utilizar-se da mudança do mediador como mecanismo de pressão sobre ele, obrigando o mediador a ceder ou submeter-se aos desejos das partes. (LANZ; SGUAITAMATTI, 2009, p. 10)

A mediação negativa, como é chamado o "jogo de mediador", não se restringe somente às ONGs, mas engloba todos os atores relacionados à mediação. Para evitar a ocorrência desta limitação, as ONGs devem restringir ou melhorar a coordenação da interação com as demais ONGs. O trabalho de diversas ONGs em múltiplos projetos é positivo e pode agregar valor ao processo, desde que os projetos delas sejam complementarem e não compitam entre si, prejudicando-se. (p. 10) Até a década de 1990, as agências competiam entre si por não conhecer o trabalho da outra, em decorrência problemas de falta ou má comunicação eram recorrentes. (CHIGAS, 2007, p. 573)

$\mathrm{O}$ mediador tem a responsabilidade de que os benefícios da mediação alcancem realmente a sociedade em conflito até as suas camadas mais baixas, ou seja, as pessoas que realmente sofrem as consequências do conflito. (ver MÜNKLER, p. 14) Contudo, nos casos, em que a mediação fracassa, o mediador, sendo ele de qualquer representação, pode voltar ao seu país ou a sua instituição. No entanto, é necessário diferenciar as ONGs dos demais mediadores, pois a limitação tratada não atinge as ONGs na mesma escala dos demais. (p. 561) Considerando-se que as ONGs possuem projetos já desenvolvidos no local, relacionamentos próximos com ONGs locais ou são ONGs locais, o que dificulta a sua saída do conflito sem consequências para a própria organização. As ONGs locais ou fortemente envolvidas com a sociedade em conflito são diretamente responsáveis perante ela. (LANZ; SGUAITAMATTI, 2009, p. 10)

A aproximação das ONGs com a sociedade tem suas vantagens e desvantagens. Como colocado, a proximidade das ONGs permite que elas conheçam a sociedade, sua cultura, líderes, culturas e valores, que tenham um relacionamento com a comunidade, de onde, muitas vezes, provém a sua legitimidade na mediação. (ver RICHMOND, 1998, p. 709; CHIGAS, 2007, p. 562) Além disso, possibilita a inclusão de toda a sociedade na mediação e o trabalho no nível basilar da sociedade. Contudo, a mesma proximidade da comunidade pode fazer com que a ONG tenha uma percepção distorcida do que 
está acontecendo no país. As ONGs também podem generalizar os acontecimentos da região onde trabalham e acreditarem que aquela é a realidade em todo o país, o que normalmente não é a realidade. (NATSIOS, 2007, p. 344)

O processo de mediação bem-sucedida depende de paciência, envolvimento de longo prazo e em situação que, muitas vezes, não são consideradas de alta relevância no cenário internacional. Todavia, doadores são mais propensos a financiar e apoiar processos visíveis e localizados em países que recebem atenção internacional. A tendência dos doadores é agravada por uma das principais habilidades das ONGs mediadoras ser a mediação discreta e que necessite do envolvimento à longo prazo. Os doadores podem induzir as ONGs procurarem compromisso com casos visíveis e de resolução em curto prazo, obscurecendo a real papel das ONGs na mediação internacional e as limitando no uso das suas vantagens. (EVANS-KENT; BLEIKER, 2003, pp. 107-109) Consequentemente, as ONGs devem evitar que a sua dependência financeira dos doadores as impeçam de utilizar as suas vantagens na mediação - envolvimento de longo prazo e processo discreto. Outro ponto que deve ser considerando no tocante do financiamento das ONGs é que as ONGs internacionais são fundadas e dirigidas por sujeitos mais eminentes no contexto internacional, em decorrência recebem a maior parte do financiamento e do apoio internacional, contudo, elas devem ficar atentas para não impedir o financiamento das ONGs locais. (LANZ; SGUAITAMATTI, 2009, p. 11) As ONGs que recebem financiamento do governo são vistas como sendo extensão da política governamental do respectivo país.

No entanto, ONGs com alto grau de financiamento governamental podem ser úteis para complementar a diplomacia governamental na resolução de conflito, pois estão mais familiarizadas e confortáveis com os protocolos $\mathrm{e}$ as sensibilidades da diplomacia oficial do que as ONGs que não aceitam financiamento público. (NATSIOS, 2007, pp. 346-347) Todavia, é impossível não considerar que o alto nível de financiamento público das ONGs resulta em uma menor independência da política estatal. A menor independência por parte das ONGs frente a política dos seus financiadores tem consequências na imparcialidade delas na mediação. (ver KLEIBOER, pp. 369-370; RICHMOND, p. 709) 
A aproximação a atores locais e a inclusão de partes locais no processo de paz são fundamentais para o sucesso da mediação, muitas vezes, mais do que as negociações oficiais. No entanto, deve-se atentar para os conflitos extremamente polarizados, onde todos os atores presentes no conflito podem estar envolvidos, inclusive as ONGs. Nesta situação, os atores internacionais, sem uma história de envolvimento no conflito, podem ser a melhor opção para conquistar a confiança das partes. Um dos desafios-chaves na mediação internacional, especialmente no que tange às ONGs, é encontrar o equilíbrio entre estar dentro ou distanciar-se do conflito. (LANZ; SGUAITAMATTI, 2009, p. 11)

As negociações de paz são mais eficazes quando processos distintos mediação oficial e não-oficial - são combinados e reforçam-se, contudo, muitas vezes, a relação entre as duas modalidades de mediação são inexistentes, pois os encarregados da mediação oficial não têm consciência das potencialidades dos processos informais ou realizado por intermediários locais, o que é prejudicial para a mediação, pois as ONGs que trabalham na segunda via da mediação facilitam o processo informalmente antes, depois ou/e em paralelo com a negociação oficial, podendo ser extremamente eficazes no processo. As ONGs, então, precisam ser pró-ativas em procurar canais informais e de influência no que tange ao processo dos mediadores formais. (pp. 11-12)

O processo de paz pode ser altamente perigoso, ao considerarmos os vários grupos sociais em conflito que podem perder, caso a mediação seja bem-sucedida e a paz estabelecida. Os mediadores locais correm risco em decorrência disto, especialmente quando a mediação falha e os atores internacionais retiram-se. $\mathrm{O}$ desafio para as ONGs internacionais é trabalhar em conjunto com as ONGs locais, colocando em prática medidas que mantenham a segurança das ONGs locais e delas próprias. (p. 12)

As decisões tomadas habitualmente no início de um projeto, tais como quais serão os participantes/beneficiários, a contratação do pessoal local, a escolha dos parceiros locais e sobre onde e qual o auxílio será concedido, podem criar linhas de divisão ou reforçar as ligações entre as camadas do conflito. Por exemplo, um critério de contratação da ONG pode agravar o conflito por limitar o acesso ao emprego e ao grupo que possui um nível mais elevado de educação, o que não está homogeneamente disseminado na sociedade, criando intergrupos na divisão 
das linhas do conflito. (NATSIOS, 2007, p. 346-347) (ver KRIESBERG, 2007, p.461)

O comportamento das ONGs e de seus membros perante os participantes pode degenerar conflitos ou promover impactos indesejáveis na gestão do conflito. Por exemplo, quando uma das partes dos negociadores é excluída por não falarem a mesma língua do mediador ou fazer reuniões em separado entre as partes pode fazer com que os outros participantes tenham uma perspectiva da mediação como tendenciosa e o esforço de diálogo piora a divisão entre os lados. As limitações programáticas sobre o impacto das ONGs na mediação não são inerentes ao seu papel e suas características, existem opções para evitar ou atenuar os impactos negativos e para a concepção e a implementação dos projetos seja feita de forma a reforçar as capacidades locais para a paz. (CHIGAS, 2007, 573)

As ONGs concebem a paz construída na sociedade. Contudo, muitas vezes, elas adotam posturas e programas, nos quais a paz não é articulada e discutida devido às particularidades do conflito. A própria ONG limita o seu trabalho em um contexto mais amplo ou macro de diferentes formas. Primeiramente, não realizando uma análise identificando os fatores que impulsionam o conflito e não abordando os elementos importantes para a resolução do conflito ou a construção da paz. (ANDERSON; OLSON, 2003, p. 64) A história do conflito, as implicações, as razões do conflito na sociedade e o conhecimento sobre a sociedade como um todo são fundamentais para a mediação ser planejada e o resultado ser o desejado.

Esta limitação afeta a todos os mediadores, sendo assim todos eles precisam analisar e entender completamente o conflito antes de iniciar a mediação. No aspecto tratado, as ONGs possuem duas vantagens, que já foram relatadas no capítulo anterior. A primeira é a sua interação com ONGs locais, as quais estão mais presentes na sociedade e consequentemente conhecem o conflito mais profundamente e podem ter especialistas sobre a região e o conflito especificamente. (ver NATSIOS, pp. 343-344)

Entretanto, para o perfeito funcionamento da vantagem abordada é necessário que o trabalho da ONG local e da ONG internacional sejam coordenados entre si e com as demais ONGs que atuam no conflito. A segunda vantagem é que a maioria das ONGs possui especialistas sobre as regiões do mundo e conflitos como membro, o que lhes facilita conhecerem o conflito e suas 
peculiaridades. Todavia, as ONGs que não realizam um estudo aprofundado do conflito e aplicam os mesmos programas acreditando na similaridade dos conflitos, possuem um limite no seu campo de ação e limitam o seu alcance, impedindo alcançar os seus objetivos macros. (p. 54)

Os impactos mais significativos para a paz ocorrem após a transformação pessoal, o que é possível somente quando as ONGs realizam os seus diversos programas, os quais são voltados, na sua maioria, para a transformação pessoal pela paz, abordagem da percepção, sentimento, entre outros, cuja tradução dá-se em ações no plano público, político institucional e nas esferas das atividades. Ao mesmo tempo em que a mudança individual é fundamental para a construção da paz, é necessário que a esperança na mudança envolva toda a sociedade. (CHIGAS, 2007, p. 575)

Porque os indivíduos que participam dos projetos das ONGs precisam acreditar que podem mudar a realidade do país; tendo assim, iniciativa em reproduzir as suas experiências. (p. 574) A reprodução de experiências é fundamental para os programas de mudança da estrutura do conflito para uma de paz, devido a impossibilidades das ONGs em atuar com cada indivíduo particularmente, elas precisam atuar na sociedade utilizando-se de multiplicadores. (LANZ; SGUAITAMATTI, 2009, p. 6) Percebe-se, então, a importância na interligação entre as atividades das ONGs conseguirem atingir todos os quadrantes do conflito e evitar consequências negativas das suas ações. As ONGs não precisam ter programas direcionados para todos os quadrantes, mas precisam conectar-se às atividades de outras ONGs através das abordagens de mudança pessoal de pessoas chaves tanto no nível individual/pessoal como no sociopolítico com o máximo de eficácia. (CHIGAS, 2007, p. 574)

\subsection{Conclusão}

A mediação de ONGs possui contribuições significativas para a mediação internacional, principalmente ao considerar as peculiaridades dos conflitos complexos. No entanto, como todo mediador, ela possui vantagens e limitações que têm que ficar muito claras para as ONGs e no momento de analise do mediador mais adequado para a mediação. Outro ponto importante a destacar é que nenhum mediador vai suprir todas as necessidades do conflito complexo. 
Muitas vezes é necessário que se tenha uma comunhão de esforços com mais de um tipo de mediador para conseguir responder eficazmente ao conflito.

A entrada de novos atores na mediação internacional foi uma das grandes modificações desse campo nas últimas décadas. As ONGs anteriormente possuíam somente o papel de responder as crises humanitárias de forma pontual, no entanto, elas são cada vez mais pressionadas a prestar outros serviços vitais que não existem em sociedades em crise, excedendo o seu papel original. A pressão é proveniente de duas fontes. A primeira é o desejo das próprias ONGs e da necessidade das ONGs desempenharem novas funções no pós Guerra Fria. A segunda é por parte dos Estados que cada vez mais delegam novas responsabilidades as ONGs em locais em conflito que eles não querem se envolver. (NATSIOS, 2007, p. 342)

As ONGs podem realizar, consideráveis contribuições à mediação internacional, incluindo atuar como mediador principal do conflito. Nesse papel a ONG atua como mediador ou conciliador direto entre as partes em conflito, por meio da facilitação da comunicação ou pelo fornecimento de informações, tentando a solução para o conflito ou questão especifica em litígio. Nessa situação a ONG utiliza-se do poder informacional, referente e perito. Como mediadora a ONG tem maior capacidade de iniciar discussão, facilitar a comunicação e explorar novas ideias do que os outros atores da mediação internacional, por não está ligada a nenhum governo ou organização internacional. Um exemplo claro que ONG como mediadora principal é a Comunidade Sant'Egidio em Moçambique, que utilizou-se do seu relacionamento de confiança anterior com as partes para conseguir mediar o conflito.

Porém, as ONGs não se limitam apenas a essas atividades, mas também participam das atividades que os mediadores mais poderosos não participam, tal como: colocar temas e os conflitos na agenda internacional e na construção de capacidades de mudança dentro do conflito. (ver SAMPSON, 2007, pp. 280-288)

Como colocado no capítulo anterior aspectos da mediação internacional ganham projeção quando considerado os conflitos complexos, sendo que um deles é a mudança de perspectiva. As ONGs possuem uma vantagem considerável nesse aspecto, pois elas conseguem lidar com as partes subjetivas e sócio-psicológicas do conflito. Os mediadores tradicionais não possuem esta capacidade, porque os instrumentos utilizados por eles são burocratizados, elitizados, rígidos e 
inadequados para esses conflitos. Já nas mediações realizadas por ONGs um dos principais sucessos é a quebra de estereótipos negativos e generalizados. As atividades realizadas pelas ONGs centram-se em fazer com que as partes quebrem concepções errôneas entre elas, fazendo inclusive com que elas identifiquem "coligações de parceiros" do outro lado, o que permite a abertura de canais de negociação, ou seja, percebem que as opiniões dentro de cada grupo não são unas e possuem sub-grupos que podem partilhar dos mesmos interesses de sub-grupos em outro grupo. As ONGs tendem a ser mais bem adaptadas para a mediação de conflitos que precisam primeiramente da mudança de perspectiva, pois podem construir um local de negociação com menor pressão política, mais criativa, interação informal entre os participantes e conseguem envolver toda a sociedade por meio de diversos projetos. (CHIGAS, 2007, pp. 553-556) A desmistificação da outra parte como inimigo ou terrorista é fundamental para a construção da paz sustentável, somente com esta mudança é que se consegue construir uma sociedade após o conflito.

As ONGs possuem também como vantagem terem a disposição de grupos de especialistas em determinadas áreas, o que permite com que elas tenham um maior conhecimento sobre o conflito e sua cultura. $\mathrm{O}$ alto conhecimento sobre o conflito é fundamental para a mediação, pois todo mediador precisa saber quais são as reais causas, suas consequências e o melhor plano de ação para o conflito. Não é possível que o mediador inicie o processo de mediação sem um profundo conhecimento sobre o conflito e uma estratégia de mediação construída, caso isto não aconteça o mediador perde o seu poder referente e a sua capacidade de influenciar e entender as partes.

O conhecimento do conflito e cultural local também pode se dar devido à inserção da ONG no conflito durante anos, como é o caso da Comunidade Sant'ÉEidio em Moçambique que estava inserida no conflito desde 1977. A consequência disto é que o mediador pode possuir um longo relacionamento com as partes ganhando a sua confiança; ter um alto conhecimento cultural da sociedade em conflito, possibilitando adaptar as suas abordagens a ela e conseguir identificar quais são as estratégias ideias para serem implementadas no conflito, facilitando assim o processo efetivo de mediação. (NATSIOS, 2007, pp. 343-344)

A prolongada inserção da ONG no conflito possibilita ainda que ela construa uma rede de conhecimento, a qual permite as ONGs envolverem-se em 
toda a sociedade, penetrando a mediação em todos os níveis sociais e conhecer a cultura, costumes e crenças do conflito.

O poder do mediador é um dos pontos mais relevantes quanto se trata da mediação de ONGs, porque a maior critica e limitação em relação às ONGs é a sua falta de poder econômico e militar. É fundamental perceber que o poder não limita-se a esses dois tipos, mas é mais amplo e inclui diversas capacidades das ONGs em intervir e influenciar o conflito. As ONGs possuem o poder referencial, informacional, perito e legitimo, sendo que este último deriva, provavelmente, do seu relacionamento de confiança com as partes. No entanto, a falta do poder militar e econômico pode ser um beneficio ou uma limitação, dependendo da situação e do comportamento da ONG. A falta desses dois tipos de poder pode ser uma barreira caso o conflito não esteja maduro ou a(s) parte(s) não deseje(m) negociar, o que não raro em conflitos complexos, nos quais as partes possuem ganhos econômicos em continuar o conflito. Pois, o mediador não terá os dois poderes que mais eficazmente e rapidamente incentivam a mediação.

É inegável que as ONGs possuem esses dois poderes como deficiência, porém, é necessário considerar que os mediadores só possuem os poderes que as partes concordam em fornecer a ele, ou seja, os mediadores só conseguem utilizar o seu poder se as partes concordarem e se elas concordarem com a própria mediação. Pode haver casos em que as partes só concordam com a mediação de um ator sem esses dois poderes, como foi o caso do Henry Dunant Center for Humanitarian Dialogue no Aceh. Além disso, há o aspecto negativo da utilização desses dois poderes. O poder financeiro pode causar dependência às partes fazendo com que elas só aceitem o acordo devido aos ganhos econômicos que teriam, o que é o oposto da solução real ao conflito que a mediação se propõe a fazer. O poder coercitivo pode ser desvantajoso caso as partes se sintam ameaçadas ou pressionadas pelo mediador a aceitar o acordo. Sendo assim, observa-se que em algumas situações a falta do poder financeiro e militar são favoráveis a mediação. Além disso, caso seja extremamente necessário a utilização desses dois poderes o mediador de ONG pode incluir outro ator na mediação para este responder a essas necessidades do conflito.

Visto que apesar de a presença de muitas ONGs e atores ser considerada uma potencial limitação das ONGs, devido a competição que poderia surgir entre elas dentro da mediação, a participação de diferentes tipos e vários mediadores 
não é prejudicial a mediação. Pelo contrário, a diversidade de atores faz com que a mediação seja mais completa e consiga responder com mais rapidez, agilidade e capacidade as necessidades do conflito. Porém, é imprescindível que a ação de todos esses atores seja coordenada pelo mediador principal, porque caso isto não aconteça a mediação vai enfraquecer com as atitudes contraditórias adotadas pelos mediadores. O mediador principal então teria o papel de coordenar as ações de todos os mediadores, consequentemente ele precisa ser capaz de entrar em contanto com diversos níveis do conflito e diferentes tipos de atores envolvidos na mediação. Diante dessas características fica evidente que o mediador de ONG deve ser colocado nesta função. (BRACHET; WOLPE, 2009, p.2) Como foi o caso dos dois casos, que serão analisados nos próximos capítulos, pois tanto no Aceh como em Moçambique a ONG mediadora principal solicitou apoio de outros atores como Estados, ONU e outros grupos. 


\section{4. Moçambique}

O conflito de Moçambique iniciou-se devido a uma interferência da Rodésia, que ajudou a formação da RENAMO (Resistência Nacional Moçambicana). No entanto, a insatisfação da população já estava presente e claramente os líderes da FRELIMO (Frente de Libertação de Moçambique) não tinham preparo e capacidade de construir um Estado com todas as funções que são necessárias, mesmo com o auxílio da ex-União Soviética.

O envolvimento da Comunidade Sant 'Egidio no conflito é longo e, durante este processo, ela conseguiu criar uma rede de conhecimento tanto internamente no conflito como externamente, o que foi fundamental no momento da mediação e um dos fatores que fizeram a mediação ser bem-sucedida. $\mathrm{O}$ longo relacionamento ainda permitiu que a Comunidade tivesse um alto conhecimento sobre o conflito e um relacionamento de confiança com as duas partes, outros fatores importantes na mediação.

Além disso, a Comunidade conseguiu envolver outros atores na mediação sobre a sua coordenação, permitindo que ela suprisse quando necessário as suas deficiências, de poder, por exemplo, com a participação desses outros atores, conseguindo assim preencher todas as indigências vindas do conflito.

\subsection{Comunidade de Sant'Egidio}

Em 1968, o então jovem estudante, Andrea Riccardi, reuniu um grupo de estudantes e formou a Comunidade de Sant'Egidio, a qual se baseava na fé cristã e trabalhva fundamentada nas mudanças previstas no Concílio Vaticano II, com especial atenção à ênfase no diálogo com os seguidores de outras religiões e no trabalho com os pobres. (HUME, 1994, p. 15)

Apesar de só ter sido reconhecida pela Igreja na década de 1980, a Comunidade de Sant'Egídio sempre teve uma forte ligação com a igreja católica, e o momento histórico foi muito importante na sua criação e desenvolvimento. (BARTOLI, 2005, p. 84) Sendo assim, a sede da Comunidade de Sant'Egídio fica situada no antigo Convento Carmelita, construído no século XVI, que foi 
reformado e transformado em um labirinto de áreas de recepção, salas de reunião e escritórios.

Atualmente, a Comunidade de Sant'Egídio é uma organização laica que conta com a participação de mais de 50 mil pessoas, as quais trabalham na Itália e em mais de 70 países. O compromisso, a tolerância e o diálogo da Comunidade levaram-na, ao contrário de muitas outras organizações de caridade ou voluntária, a exercer atividades políticas. Consequentemente, os líderes da Comunidade possuem contato com políticos italianos e funcionários do governo. (HUME, 1994, pp. 16-17)

A preocupação com os pobres fez com que a Comunidade de Sant'Egídio percebesse que, em muitas situações, a guerra era a causadora de todas as pobrezas e devido a isso a melhor maneira de trabalhar significativamente pelos pobres era trabalhar pela paz, defendê-la quando ela está ameaçada, ajudando a reconstruí-la, facilitando o diálogo no qual ela estava perdido. Quando a situação não possibilita o trabalho pela paz, a Comunidade de Sant'Egídio procura realizar trabalhos de solidariedade, ajuda humanitária à população que sofre por causa da guerra. (COMUNIDADE SANT’́EGIDIO SITE) A Comunidade compartilha dos preceitos católicos de reconciliação, isto está presente na sua mediação. O que é extremamente importante nos conflitos complexos, pois como o conflito está difundido por toda a sociedade é necessário que o mediador faça um trabalho de reconciliação com toda a sociedade. (ver NATSIOS, p. 379)

A Comunidade Sant'Egídio possui como metodologia de trabalho a utilização da sinergia de esforços entre todos os níveis da sociedade - sociedade civil, instituições oficiais e não oficiais - para dessa forma conseguir realizar o seu trabalho pela paz em um mundo complexo do pós-Guerra Fria, no qual todas as forças precisam cooperar. A Comunidade trabalha em todos os níveis do conflito, como aconselha o modelo piramidal no primeiro capítulo. (ver LEDERACH, 1997) A Comunidade trabalha em todos os níveis do conflito, o que contribui de forma acentuada para o processo de paz, e é essencial para responder às questões de garantias. A presença de níveis institucionais, Estados e organizações internacionais, asseguram a importante função de dar garantias a ambas as partes. As garantias internas e externas são necessárias para a realização do processo de mediação, sendo a garantia interna, em certos casos, a partilha do poder e a parceria de ambos os partidos políticos na administração. Elas também 
se revelam necessárias nos processos de aprendizagem sobre democracia, o qual exige a aceitação do pluralismo em todas as esferas - política, religiosa, cultural e étnica - do país. (COMUNIDADE SANTEGIDIO)

O aprendizado democrático e a aceitação do pluralismo eram essenciais para a resolução do conflito de Moçambique, o qual foi mediado pela Comunidade Sant'Egidio, visto que os partidos que disputavam o conflito, RENAMO e FRELIMO, não possuíam cultura política desenvolvida, ao contrário, os objetivos deles eram somente o poder e o controle do aparato do Estado, essa situação era mais forte ainda com a RENAMO, a qual até hoje não conseguiu formar uma forte plataforma política para chegar ao poder. (HUME, 1994, p. 8) A luta pelo controle do aparato estatal é uma das motivações dos conflitos complexos, bem como a destruição deste aparato durante o conflito. (ver BUTLER, 2009, p. 58)

No processo pela paz, a conversão da cultura de combate, guerra ou guerrilha para uma cultura política é fundamental. Em toda negociação existe um problema de "memória patológica", o qual deve ser curado por meio de negociações em si, através da construção própria e verdadeira para a vida civil e para a democracia. Isto ocorre porque cada beligerante e até mesmo os civis tornam-se prisioneiros da memória, a memória das injustiças vividas, das vitimas, e do tempo de luta contra a guerra. (ver AYRES, 1997, p. 423) As negociações combatem um tipo de cultura existencial, o que é essencial para orientar o conflito para o terreno político. O objetivo de cada negociação para a Comunidade de Sant'Egídio é desenvolver às partes, o desejo, o fascínio pela paz e a expectativa de um futuro comum. (COMUNIDADE SANT'EGIDIO) A Comunidade não está preocupada em somente estabelecer um Acordo de Paz, mas também em realizar mudanças de perspectivas, um plano de reconciliação de toda a sociedade e construção de valores políticos e culturais, os quais permitirão que a paz sustentável seja estabelecida naquela sociedade. (ver DEBRIX, 1999, p. 196; RICHMOND, 1998, p. 721)

\subsubsection{O conflito}

A mediação realizada em Moçambique foi apoiada por uma série de atores que devem ser considerados no momento que analisamos o sucesso na resolução 
do conflito. Moçambique também teve um papel fundamental com os seus partidos, suas alianças e, mais importante, a população em geral estava pronta para a paz a longo prazo. O sofrimento humano causado pela guerra, a impossibilidade de planejamento a longo prazo, o estado de constante medo e desespero da população, tinham levado a uma busca por condições de paz. (BARTOLI, 1995, p. 82) Os fatores que levaram ao desgaste das partes e de toda a sociedade moçambicana deixam evidentes as características de conflitos complexos: o ataque à população, a propagação do medo e a destruição da estrutura física estatal.

Considerando-se esses fatores, no momento em que as condições regionais e internacionais - mudança na postura da África do Sul frente ao conflito e fim da União Soviética e consequentemente da Guerra Fria - ofereceram a oportunidade às lideranças moçambicanas para realizar um plano para chegar até os setores que haviam lutado por longo período. O apoio externo militar e econômico recebidos pelas duas partes tanto das então Grandes Potências como da África do Sul e anteriormente do Zimbábue faziam com que as duas principais frentes de luta em Moçambique - FRELIMO e RENAMO - não desejassem retirar-se do conflito. No entanto, quando esse apoio é retirado, as duas frentes ficam motivadas a procurar a mediação. A retirada do apoio externo foi possível devido ao fim da Guerra Fria, consequentemente o fim da guerra de procuração que acontecia neste país, e a negociações com a África do Sul para retirar o apoio a RENAMO, o que também foi incentivado pelo fim da Guerra Fria. O regionalismo, como a Guerra Fria, possui alta influência no conflito. Primeiramente, a RENAMO foi criada com a ajuda do Zimbábue (ex-Rodésia) que pretendia desviar a atenção do governo moçambicano do conflito no Zimbábue, posteriormente, todo o seu patrocínio é proveniente da África do Sul, enquanto, a FRELIMO é apoiada pela ex-URSS. (ver MIALL; RAMSBOTHAM; WOODHOUSE, 2009, pp. 98-99)

A Resistência Nacional Moçambicana (RENAMO) liderou um estudo das formas em que poderiam transformar-se de forma militar em partidos políticos, participando na construção de uma democracia inclusive em Moçambique. (BARTOLI, 1995, p. 82) Os fatores apresentados demonstram que o conflito apresentava características de maturação que devem ser consideradas no momento de análise da efetividade da mediação e do seu sucesso, como colocado no capítulo anterior, a maturação do conflito é necessária, mas não imprescindível, 
para que a mediação consiga ser eficaz. (ver BERCOVITCH, 1984; ZARTMAN; TOUVAL, 2007, p. 445)

Organizações internacionais, regionais e representantes do setor privado agiram como atores de mudança para realizar o processo de paz, porém, o papel principal da mediação foi a ONG, Comunidade Sant'Egidio, a qual centralizava e coordenava os esforços pela paz. Dois representantes da Comunidade, Andrea Riccardi e Matteo Maria Zuppi faziam parte da equipe informalmente formada por terceiros os quais, por mais de dois anos, liberou o processo em Roma para sua conclusão com êxito. (pp. 82-82)

O envolvimento da Comunidade de Sant'Egídio foi respondendo rapidamente às aberturas positivas apresentadas no conflito, incluindo-as em quadro interpretativo maior e mais criativo. As pressões constantes trouxeram os dois partidos para falar com os membros da Comunidade, e posteriormente, diretamente com a outra parte. O que foi realizado em um processo progressivo explorando possibilidades criando gradualmente a aproximação entre as partes. Pois, a inimizade entre os dois grupos era elevada devido a diversos fatores que possuíam origens diferenciadas. No plano ideológico, a Frente da Libertação de Moçambique (FRELIMO) defendia a perspectiva marxista-leninista, enquanto, a RENAMO possui uma visão pró-democrática; na estratégia militar o número significativo de mortes brutais e de violência; e a falta de contato direto e distintas afinidades tribais. (pp. 89-90) (ver CHIGAS, 2007, pp. 561-566)

Observa-se aqui uma das principais vantagens das ONGs na mediação, a sua flexibilidade e baixa burocracia permitiram que a Comunidade Sant'Egidio respondesse rapidamente às oportunidades apresentadas pelo conflito. O poder informacional também foi muito importante na mediação para conseguir que as partes mudassem a sua perspectiva quanto a outra parte, visto que durante o conflito o "outro" foi demonizado e não tinha um canal de comunicação entre eles, o que é uma característica dos conflitos complexos. (ver AALL, 2007, pp. 481-482; AALL, 1996, p. 3; RICHMOND, 1998, 721)

Os dois partidos estabeleceram uma relação de confiança independente com a Comunidade Sant'Egídio. Ambas as relações foram de grande prazo, abertas, transparentes, respeitosas e permitiram a exploração de opções políticas que anteriormente eram consideradas disponíveis. (p. 80) O que possibilitou que a Comunidade Sant 'Egidio utilizasse do seu poder referencial durante a mediação. 
Este relacionamento anterior, o qual será melhor desenvolvido posteriormente, foi o que deu legitimidade à Comunidade como mediadora do conflito. Além de proporcionar a ela um alto nível de conhecimento do conflito, sobre as partes e a cultura local. (ver AALL, 2007, pp. 483-484; KLEIBOER, 1996, p. 369; KRIESBERG, 2007, p.461)

Apesar do desenvolvimento das relações pessoais da Comunidade de Sant'Egidio, principalmente com o Bispo Gonçalves, ter sido essencial para o seu envolvimento a longo prazo e seu sucesso, devo destacar que a disponibilidade delas em explorar alternativas que se adaptavam ao cenário específico moçambicano foram essenciais para o sucesso da mediação. (p. 80) O relacionamento com o Bispo Gonçalves foi essencial, pois fazia com que a Comunidade Sant'Egidio tivesse acesso a toda a rede de igrejas católicas em Moçambique, o que era muito forte na sociedade e, em algumas localidades, a única autoridade presente, devido à colonização portuguesa. Além disso, a divisão tribal de Moçambique fazia com que a igreja católica fosse a única com presença em todo o território. (ver CHIGAS, 2007, 561; LANZ; SGUAITAMATTI, 2009, p. 6)

Anteriormente ao aprofundamento da mediação, é fundamental entender como as partes se desenvolveram e o contexto do conflito. A FRELIMO foi fundada em 1962 no período pré-independência de Moçambique por três grandes grupos nacionalistas com a liderança de Eduardo Mondlane com o objetivo de consegui-la. (p. 60) A luta armada pela independência iniciou-se em 1964 e possuía reivindicações que não se limitavam a ela, tendo também que libertar o povo das autoridades tradicionais, pretendendo reestruturar a sociedade nos moldes do socialismo cientifico, devido a maioria da sua liderança ter procedência das tribos do sul do país. (HUME, 1994, p. 8) A libertação do povo das autoridades tradicionais na realidade era a perseguição às particularidades das tribos presentes em Moçambique, percebe-se, aqui, o choque entre a formação do Estado nacional uno e a autodeterminação dessas tribos, que desejavam manter as suas culturas. (ver CARMENT, 2003, pp. 413-414)

Com a independência, em 25 de junho de 1975 (RUPIYA, 1998, p. 12), Samora Machel foi empossado como primeiro presidente moçambicano, tornando a FRELIMO o único partido do país, eliminando qualquer possibilidade de pluralismo político. (LALA; OSTHEIMER, 2003, p. 6) No seu primeiro discurso, 
Machel prometeu uma política não-racial, política e anticapitalista, claramente baseada ideologicamente no nacionalismo e socialismo, os quais confrontaram a identidade tradicional e as estruturas tradicionais de poder. (BARTOLI, 1995, p. 80) A contraposição entre o discurso de Machel e a estrutura social moçambicana, a qual era tribalista, deixa claro o choque entre o Estado central e os líderes regionais, entre a construção do Estado nacional e a autodeterminação, gerando a fragmentação das forças que lutaram pela independência. (ver BUTLER, 2009, p. 58)

A FRELIMO tinha como objetivo modernizar o país, disciplinando-o ao socialismo. Buscou legitimar-se, proclamando-se um partido de vanguarda que iria proteger a revolução e promover o desenvolvimento, subjugando autoridades tradicionais que tinham permanecido na colonização.

O governo nacionalizou casas particulares, de aluguel, terrenos privados, a prática da medicina e da lei e as instituições educacionais. Assumiu a responsabilidade pela gestão das empresas e fazendas nacionalizadas, apesar de não possuir funcionários treinados e experientes, tentou substituir os preços no mercado por administrados, atitudes as quais aumentaram a tensão. (HUME, 1994, p. 9) As identidades tribais, religiosas e regionais moçambicanas foram subestimadas e a identidade nacional e o nacionalismo promovidos, o governo foi particularmente severo com as autoridades tradicionais. (BARTOLI, 1995, p. 80) Fica claro que a FRELIMO não possui estrutura e conhecimento para a construção de um Estado. A colonização portuguesa não estabeleceu instituições fortes capazes de implementar o Estado moçambicano e as poucas instituições criadas durante a colonização não contavam com a participação do povo moçambicano. (ver MIALL; RAMSBOTHAM; WOODHOUSE, 2009, p. 86; CARMENT, 2003, p. 410-414)

Diante da situação, técnicos do bloco oriental, socialista, foram para Moçambique e treinaram a sua burocracia. (HUME, 1994, p. 9) Em novembro de 1980, no final de outra visita à União Soviética, Machel assinou uma declaração conjunta que alinhava a política externa moçambicana com a soviética.

O conflito com a Rodésia foi a principal questão de segurança do governo Machel, devido à política do regime de minoria branca estabelecido por Smith. O 
governo de Machel fechou o corredor de Beira ${ }^{18}$ e, a partir de bases situadas na parte ocidental de Moçambique, Mugabe com a União Nacional Africana do Zimbábue (ZANU) aumentaram a pressão sobre a Rodésia. Em retaliação, Smith atacou áreas no interior moçambicano, incluindo infra-estrutura, tal como: pontes, barragens e ferrovias. Decorrente deste contexto, foi criada a Resistência Nacional Moçambicana (MNR), a qual posteriormente foi chamada de RENAMO (Resistência Nacional Moçambicana), movimento insurgente em Moçambique e apoiado pelo Rodésia que utilizou a sua inteligência para ajudar a fundar o movimento. O objetivo da Rodésia era que a RENAMO fornecesse informações sobre o ZANU e mantivesse a pressão sobre o governo de Machel. (pp. 9-10) O conflito na Rodésia acabou por envolver Moçambique devido às influências que o conflito poderia gerar no país. Em resposta, a Rodésia financiou e treinou o grupo insurgente RENAMO com o objetivo de que a sua atuação em Moçambique desviasse a atenção moçambicana da Rodésia. Fica claro nesta interação que situações regionais podem exacerbar ou até mesmo criar as situações para o conflito. Como colocado no capítulo anterior, o regionalismo ganha importância no pós-Guerra Fria, mas ele já estava atuando fortemente antes a este período, no entanto, era encoberto pelo grande conflito da Guerra Fria. (ver MIALL; RAMSBOTHAM; WOODHOUSE, 2009, pp. 98-99)

A insatisfação quanto à tensão entre estruturas tradicionais e inovações ideológicas foi o segundo fator de criação da RENAMO, o qual teve como primeiro líder André Matsangaíssa. (BARTOLI, 1995, p. 81) Obviamente, a Rodésia não tinha como criar um grupo insurgente sem que a insatisfação já não tivesse iniciado em Moçambique. A tensão entre as estruturas tradicionais e as inovações ideológicas realizadas pelo governo era um fator potencial para o conflito, principalmente se considerarmos a falta de preparo da FRELIMO para a construção do Estado, a falta de instituições de resolução de conflito e voltadas para a minoria e a perseguição às autoridades tribais e seus mecanismos tradicionais de resolução de conflitos. (ver CARMENT, 2003, p. 413-414)

Nos primeiros dias foram recrutados muitos que tinham experiência militar anterior, alguns serviam nas forças portuguesas em Moçambique e outros, como

${ }^{18} \mathrm{O}$ corredor da Beira é a ligação com o Zimbábue por via rodoviária e ferroviária e facilita o acesso do interior do continente ao litoral. (Timeout. Província de Sofala. Disponível em: <http://www.acismoz.com/lib/services/publications/docs/Beira\%20Importacao\%20Exportacao\%2 0Edicao\%20I\%20Portugues.pdf $>$ Acessado em 09 de fevereiro de 2012. 
Matsangaíssa, serviam na tropa da FRELIMO. A RENAMO fazia o seu recrutamento dentro de Moçambique, saqueava suprimentos militares das forças do governo e alimentos da população. (HUME, 1994, p. 13; MÜNKLER, 2004, p. 14) Devido à natureza unipartidária do regime político, não foi possível a RENAMO lutar politicamente por suas reivindicações, sendo a única opção a luta armada para alcançar as suas exigências, o que resultou no conflito civil Moçambicano em 1977. A RENAMO foi criada e desenvolveu-se com o objetivo de defender a democracia, implementar o multipartidarismo e, principalmente, substituir a FRELIMO no poder. (MANNING; MALBROUGH, 2008, 78-80) As forças que uniram-se para lutar pela independência agora fragmentavam-se devido às tensões entre o tradicional e as propostas implementadas pelo governo. Além disso, a RENAMO fazia o seu recrutamento dentro da sociedade moçambicana e utilizava-se do saque para se sustentar. Outro ponto importante que caracteriza esse conflito como sendo um conflito complexo é a percepção da RENAMO de que a única forma de que suas reivindicações sejam debatidas e ouvidas é pela luta armada. A falta de diálogo político, instituições competentes e o unipartidarismo fazem com que a sociedade seja fechada e os grupos insatisfeitos acreditem que não tem outro modo de reivindicação. (ver BUTLER, 2009, pp. 5859; CARMENT, 2003, p. 415)

O conflito em Moçambique iniciou-se em 1977, muito tempo antes do fim da Guerra Fria, no entanto, já encontramos nele características claras dos conflitos complexos. Como colocado no primeiro capítulo, apesar do sistema internacional só começar a perceber os conflitos complexos após o fim da Guerra Fria, as características deles já eram encontradas nos conflitos do terceiro mundo desde a década de 70. Em contrapartida, as forças em Moçambique eram concentradas em dois grupos beligerantes, apesar da existência de diversas milícias e grupos armados que vão se envolvendo durante o conflito, devido ao apoio externo que eles possuíam dos dois blocos ideológicos. (ver RAMSBOTHAM; WOODHOUSE; MIALL, 2009, p. 83; NATSIOS, 2007, p. 338)

Em 1979, Margaret Thatcher aprovou o plano para buscar uma solução negociada para a guerra na Rodésia. Conseguiu-se chegar a um acordo e a transferência formal de poder na Rodésia ocorreu em 1980, o que foi um sinal de esperança para Moçambique, visto que nenhum país tinha sido tão afetado com o 
conflito. Devido à mudança de contexto, o governo de Machel podia concentrar-se na política interna que estava bastante complexa. (HUME, 1994, p. 10)

O início da década de 80 foi marcada pela seca e recessão mundial fazendo com que o setor agrícola tivesse resultados péssimos e a insistência do governo em um regime de partido único e controle estatal piorou a situação. A política governamental interna, em resumo, era a Operação Produção que transferia milhares de pessoas das principais cidades para trabalhar no campo, o que causou uma pequena revolta das pessoas, as quais reclamavam da transferência forçada e acreditavam que era uma punição. No entanto, o governo afirmava que a única motivação das transferências era ajudar o desenvolvimento do país, o que não teve efeito, visto que 100 mil pessoas morreram nas regiões de seca em 1983. (p. 10) Mostram-se presentes características do Estado falido, o qual não consegue suprir as necessidades básicas, como alimentação, da população. O agravamento da situação dá-se pelas medidas arbitrárias do governo, gerando revolta da população e medo de ser "punido" pelas medidas governamentais, como o trabalho forçado no campo. (ver MIALL; RAMSBOTHAM; WOODHOUSE, 2009, p. 88)

A RENAMO continuava a ser a maior ameaça interna de segurança, principalmente depois a morte de André Matsangaíssa, em 1979, e a substituição por Afonso Dhlakama na liderança do movimento. As políticas internas do governo alienaram boa parte da população, tornando mais fácil o recrutamento pela RENAMO. As forças da FRELIMO não eram mais capazes do que o exército português em controlar rebeliões rurais que utilizavam soldados, armas ligeiras e minas terrestres, apesar do treinamento e do equipamento dado pelos governos do bloco comunista. (HUME, 1994, pp. 10-11) As táticas utilizadas pela RENAMO são claramente caracterizadas dos conflitos complexos, primeiramente, a utilização da estratégia de guerrilha com armas leves (ver MÜNKLER, 2004, p. 15); em segundo lugar, o recrutamento dentro da sociedade era feito devido à insatisfação da população com o governo e o medo dela ao governo e a RENAMO (ver BUTLER, 2009, p. 58), visto que ambos utilizavam-se do ataque a civis como forma de estratégia de guerra (ver BUTLER, 2009, p. 60). As forças da RENAMO foram menos equipadas do que as Forças Armadas Moçambicanas (FAM), mas muitas vezes superaram-na em inteligência, comando, controle moral, iniciativa e tática. (p. 12) 
A RENAMO ganhou fama internacional devido às suas práticas de direitos humanos, como "Khmer Vermelho"19 da África. A estratégia de guerra da RENAMO foi contra alvos civis, a infraestrutura econômica, povoados, os quais poderiam ser pilhados para abastecer a tropa e civis que poderiam ser torturados, mutilados, assassinados, sequestrados ou até mesmo alistados e depois liberados. Consequentemente, os ataques da RENAMO foram frequentemente nos corredores de transporte, contudo o terror a RENAMO estava presente em todo o país. (pp. 14-15) (ver BUTLER, 2009, p. 60; MÜNKLER, 2004, p. 15) No entanto, essa estratégia de guerra não foi exclusividade da RENAMO, os confrontos militares entre os exércitos no campo de batalha quase não ocorreram durante a guerra em Moçambique. A estratégia utilizada pela RENAMO e a FRELIMO tinha como objetivo o ataque a civis, a propagação do medo e a destruição da infraestrutura econômica e física do Estado. $\mathrm{O}$ ataque a civis e suas comunidades tinham uma dupla finalidade; primeiramente, era para a propagação do terror e conseguir legitimar as ações do grupo; em segundo lugar, a subsistência do grupo com as pilhagens, gerando até mesmo sustento para os líderes. Esta estratégia é uma das marcas mais importantes dos conflitos complexos. (ver KALDOR, 2001; CARMENT, 2003, p. 109; MUNKER, 2004, p. 14)

Essencialmente como movimento rebelde, a RENAMO foi incapaz de desenvolver qualquer estratégia política significativa, ela não possuía uma ideologia articulada e nem uma estrutura organizacional. (BARTOLI, 1995, p. 81) $\mathrm{Na}$ luta entre a RENAMO e a FRELIMO, apresenta-se outra característica marcante dos conflitos complexos, que é a propagação do terror na população civil. Quando a RENAMO ataca a população civil em busca de subsistência alimentar e militar, ela está propagando o terror na sociedade como um todo, em decorrência da mediação terá que abordar um programa de reconciliação. (ver

19 Khmer Vermelho foi a denominação dada para os seguidores do Partido Comunista da Kampuchea, o qual governou o Camboja durante os anos de 1875 a 1979, liderado por Pol Pot Nuon Chea Lehg Sary Sen e Khieu Samphan. A Organização é lembrada principalmente pela sua política de engenharia social, a qual resultou no genocídio. As tentativas de reforma agrária implementada por eles gerou fome generalizada e a defesa da auto-suficiência em todas às especialidade levando milhares de pessoas à morte em consequência até mesmo de doenças tratáveis. Execuções brutais e arbitrárias e as torturas praticadas pelos oficiais contra os considerados "subversivos" são consideradas genocídio. (RATNER, Steven R.; Abrams, Jason S.. In: Steven R, 2001, p. 272) 
ZARTMAN; TOUVAL, 2007, p. 445; LANZ; SGUAITAMATTI, 2009, pp. 6-7; NATSIOS, 2007, p. 358; Comunidade Sant ${ }^{\prime}$ Egidio site)

Após a resolução do conflito na Rodésia, em 1979, a RENAMO passou a ser patrocinada pela África do Sul. O apoio sul-africano consistia principalmente no fornecimento de treinamento, armas pequenas, munição, suprimentos médicos e equipamentos de comunicação. O outro grupo de apoio à RENAMO era dos portugueses que haviam perdido as suas propriedades com a independência. (HUME, 1994, pp. 11-14)

Machel com o objetivo de cortar o apoio da África do Sul a RENAMO decidiu negociar um acordo, cuja política de segurança estava impulsionada pela ameaça de um alegado ataque total. Em1984, durante reuniões em Maputo e Cidade do Cabo, os dois lados elaboraram o pacto de não-agressão. $\mathrm{O}$ governo sul-africano prometeu que não continuaria a apoiar a RENAMO, em contrapartida, Machel declarou que Moçambique não apoiaria militarmente o Congresso Nacional Africano (ANC) ${ }^{20}$. Machel fechou o escritório da ANC em Maputo; entretanto, a África do Sul não retirou o apoio à RENAMO. (pp. 11-14) As questões regionais têm grande influência sobre o conflito. Não era possível iniciar uma mediação sem que as duas partes estivessem dispostas a negociar e isto só seria possível frente a retirada do apoio externo. Contudo, o interesse da FRELIMO nesse caso é que a dessimetria das forças entre ela e a RENAMO ficasse ainda mais pulsante fazendo com que ela ganhasse o conflito devido à derrota da RENAMO. (ver MIALL; RAMSBOTHAM; WOODHOUSE, 2009, p. 98-100)

Em outubro de 1984, o governo se reuniu com a RENAMO em Pretoria com o objetivo de realizar um cessar-fogo. Todavia, quando o acordo estava a ser alcançado, a RENAMO se retirou da negociação devido aos interesses dos comerciais portugueses e do governo sul-africano. Em 1985, a RENAMO intensificou os seus ataques, mas manteve sua estrutura rudimentar e a organização sombria. Percebe-se que para a resolução do conflito só seria possível caso os financiadores da RENAMO também tivessem de acordo.

${ }^{20}$ Congresso Nacional Africano é um movimento de libertação nacional criado em 1912 com o objetivo de liderar a luta pela mudança fundamental na política, social e economia. Durante 10 décadas, a ANC liderou a luta contra o racismo e a opressão, organizando a resistência em massa, mobilizando a comunidade internacional e assumindo a luta armada contra o apartheid. (African National Congress site. Disponível em: < http://www.anc.org.za/show.php?id=172> Acessado em: 11 de fevereiro de 2012) 
Em 19 de outubro de 1986, Machel morreu em um acidente de avião dentro da África do Sul, deixando um país que ainda sofria com as suas políticas governamentais, a guerra civil e o aprofundamento da pobreza. Duas semanas após o acidente, o comitê central da FRELIMO elegeu Joaquim Chissamo para a presidência de Moçambique e chefe da FRELIMO. (pp. 12-14) Em 1990, o país precisava desesperadamente de paz e reconciliação. (p. 3)

\subsection{A Resolução}

A Comunidade de Sant'Egídio envolveu-se no conflito de Moçambique quando, em 1977, o então Bispo de Beira, Jaime Gonçalves ${ }^{21}$, relatou as dificuldades enfrentadas pela Igreja Católica em Moçambique sob o comando da FRELIMO. ${ }^{22}$ A equipe da Comunidade procurou eliminar as restrições sobre a liberdade religiosa em Moçambique. No entanto, com a criação da RENAMO, em 1977, a situação da Igreja Católica e da sociedade moçambicana agora em conflito armado piorou. Nesse momento, a Comunidade de Sant'Egídio procurou eliminar as restrições à igreja se aproximando da FRELIMO e apresentando os seus líderes a líderes do Partido Comunista Italiano. Outra frente deles foi discutir as necessidades humanitárias moçambicanas e com a ajuda do governo italiano, principalmente Giulio Andreotti ${ }^{23}$ e Mario Rafaelli ${ }^{24}$, para implementarem o programa de entrega de comida e remédios em Moçambique. (p. 18) A Comunidade Sant'Egidio envolveu um Estado, no caso o governo italiano, desde do começo do seu relacionamento com a FRELIMO, objetivando ganhar peso político para as suas negociações. Sendo assim, no momento da mediação, o governo italiano também estaria envolvido no conflito e conhecendo as partes, tendo dessa forma mais autoridade para intervir e um maior custo político em não se envolver. (ver MITCHELL, 1992, p. 277; CHIGAS, 2007, 562; KELMAN, 2000, p. 275)

21 Jaime Gonçalves foi arcebispo de Beira e posteriormente Bispo, negociou a paz entre a FRELIMO e RENAMO em 1992 e solicitou sua renúncia em 2012, devido a idade máxima de 75 anos no final de 2011.(Angola Press, 17 de janeiro de 2012.)

${ }^{22}$ Nos primeiros anos de governo, a FRELIMO confiscou algumas propriedades da igreja, fechou escolas e clínicas da igreja e adotou restrições aos líderes religiosos. (HUME, 1994, p. 17) Pois, seguindo a ideologia comunista, a FRELIMO era contrária às contribuições religiosas para a vida pública, essa visão era ainda intensificada contra a Igreja Católica, a qual era vista como sendo uma relíquia colonial que deveria ser superada. (BARTOLI, 2005, p. 84)

${ }^{23}$ Chanceler italiano na década de 80. (HUME, 1994, p. 18)

${ }^{24}$ Mario Raffaelli foi sub-secretário do Ministério dos Negócios Estrangeiros italiano durante seis anos da década de 80. (HUME, 1994, p.18) 
Entre 1984 e 1988, a Comunidade iniciou vários projetos de desenvolvimento e cooperação e desenvolveu uma rede de comissões na Itália para obter fundos e materiais para Moçambique e para difundir informações na Europa sobre a crise naquele país. Uma segunda rede foi logo implementada no interior de Moçambique, muitas vezes com a ajuda das paróquias locais com o objetivo de ajudar órfãos, estudantes e outros que sofriam com a guerra. A Comunidade sofreu baixas durante ataques armados nesse período. (BARTOLI, 1995, p. 91) Como podemos perceber, a Comunidade possuía uma rede de contatos, conhecimento e suporte não somente fora de Moçambique, mas também dentro do país. Uma das estratégias utilizadas pela ONG é a chamar atenção para o conflito, conseguindo,assim, apoio internacional tanto para questões humanitárias como para a mediação. (ver LANZ; SGUAITAMATTI, 2009, p. 6; CHIGAS, 2007, p. 562)

Como foi falado no capítulo anterior, uma das vantagens das ONGs é possuir essas redes de contato, as quais proporcionam a eles a capacidade de interagir com toda a sociedade e assim conseguir realizar a mediação no modelo piramidal, que é o ideal para conflitos complexos. As ONGs utilizam-se de suas redes de conhecimentos para conseguir legitimar a sua posição, conhecer melhor o conflito, a cultura e costumes do país e conseguir acessar toda a população. $\mathrm{O}$ acesso a toda a população é fundamental, pois os conflitos complexos têm como característica o ataque à população civil, que sofre diretamente ou indiretamente, pelo ataque à infra-estrutura do Estado e pelos deslocamentos forçados; e pela propagação do terror. Em decorrência disso, o trabalho de reconciliação precisa ser feito desde o nível basilar da comunidade. Ao mesmo tempo, há que se considerar uma das limitações das ONGs com a questão de segurança, pois, as ONGs e seus membros têm que ter consciência do risco que os mediadores correm, principalmente considerando a falta de poder coercitivo das ONGs. Além disso, os membros das ONGs que iniciarem o processo de mediação têm que ter consciência dos riscos pessoais que estão correndo. (ver LEDERACH, 1997; LANZ; SGUAITAMATTI, 2009, p. 12; CHIGAS, 2007, 562; NATSIOS, 2007, pp. 343-344; KLEIBOER, 1996, p. 369)

Membros da Comunidade de Sant'Egídio desenvolveram laços com missionários em Moçambique, os quais estavam muitas vezes situados em áreas controladas pela RENAMO. Como resultado, a Comunidade conseguiu 
desenvolver uma relação de credibilidade e confiança com os insurgentes RENAMO -, ao mesmo tempo em que possuía uma relação forte com a FRELIMO. (HUME, 1994, p. 18) O poder e legitimidade do mediador de ONG, como mostra esse caso, derivam do relacionamento anterior que a ONG possui com as partes em conflito. Deve-se observar aqui que a parcialidade da ONG é até importante, mas o que realmente mantém a mediação é o relacionamento de confiança entre as partes e o mediador e a crença das partes de que a mediação com aquele mediador é a melhor solução para o conflito. (KLEIBOER, 1996, p. 369-371)

A Comunidade de Sant'Egídio foi escolhida como mediadora devido ao seu envolvimento humanitário em Moçambique desde 1977, isto destaca uma das vantagens da mediação de uma ONG frente às necessidades da mediação que é o seu relacionamento com as duas principais partes do conflito e em reuniões anteriores. Os caminhos para desenvolver o relacionamento com as partes são muito diferentes: o relacionamento com a FRELIMO foi mais longo e complexo, com reuniões ainda em 1982 e 1984, enquanto com a RENAMO foi mais intenso, especialmente no período que antecedeu as negociações.

O relacionamento com a RENAMO foi iniciado com a observação pela Comunidade das escassas aparições do partido na mídia internacional. Sabendo das dificuldades de negociar com a RENAMO, a Comunidade de Sant'Egídio tentou estabelecer uma conexão direta e confiável com o líder do grupo, Dhlakama. Seguindo os seus canais e conhecimentos, ela conseguiu a libertação de freiras que estavam sob o poder da RENAMO, e ficou claro, assim, que existia a possibilidade de negociações diretas através da Comunidade, que se tornou o ponto de ligação para um número crescente de atores, ecléticos, dispersos e desconfiados: todos expressavam interesse na relação, mas com reservas. $\mathrm{O}$ uso criativo da rede já estabelecida continuamente tinha como objetivo apoiar e tornar possível o estabelecimento de negociações diretas entre a FRELIMO e a RENAMO. Para atingir o objetivo, foi preciso intervir diariamente em relações de qualidade com todas as informações e atores relevantes, aceitando suas idiossincrasias e apoiando o seu desejo pela paz, a Comunidade percebeu, devido a isso, a importância do seu papel na criação e manutenção de relações construtivas. (p. 18) 
A visita do Papa a Moçambique deu a possibilidade estratégica da Comunidade solicitar um cessar-fogo durante a visita, o que foi aprovado. A negociação realizada pelo Bispo Gonçalves com Dhlakama foi muito útil visto os privilegiados e raros compromissos assumidos pela RENAMO e transformação na sua liderança como possível negociador direto, as reuniões foram tão produtivas devido também às semelhanças culturais (ambos eram da mesma tribo). (ver KLEIBOER, p 369) A identificação com o mediador é basilar para o estabelecimento de um relacionamento de confiança, com a identificação da parte em conflito fica mais propícia a escutar o mediador e considerar suas ideias, pois o considera como igual. Os contatos preliminares continuaram durante a primavera e o verão de 1989, quando uma delegação da FRELIMO foi a Nairóbi e reuniões foram realizadas através de terceiros - Zimbábue e Quênia -, a Comunidade resolveu estender o convite privado a Dhlakama para visitar a Itália em abril de 1989, que só foi realizado em fevereiro de 1990, por causas de problemas relacionados ao conflito. As relações pessoais estabelecidas com o Bispo Jaime eram compartilhadas com outros membros da Comunidade, que vinham acompanhando o processo desde o início. A desconfiança por parte da FRELIMO foi alta, contudo o sentimento crescente de confiança de que o processo poderia assegurar as negociações diretas crescer. (BARTOLI, 1995, pp. 94-95)

Ainda em 1988, o Presidente Chissano, em reunião com um grupo de Bispos católicos pediu informalmente que eles buscassem contato com a RENAMO, foi o início formal de um processo que estava sendo preparado há um longo período. A vontade da FRELIMO em utilizar os canais religiosos foi uma decisão acompanhada por oficiais qualificados e contraria o relacionamento anterior que eles tinham com a igreja. Houve uma melhora nas relações entre a FRELIMO e a Igreja Católica com a devolução das terras tomadas anteriormente da Igreja. Em julho de 1988, Riccardi, um dos principais membros da Comunidade Sant'Egidio, discursou durante o V Congresso da FRELIMO, encorajando os movimentos em favor das negociações e desenvolvimento de "um desejo difundido pela paz" não só entre a população, mas também entre os líderes que participavam do Congresso. (p. 92)

É fundamental ressaltar que a Santa Sé teve uma avaliação muito pessimista do trabalho da Comunidade, o qual foi considerado por diversas vezes 
demasiado ousado. Embora todos os esforços para facilitar a paz em Moçambique tivessem apoio, um envolvimento direto era considerado constantemente perigoso. A Santa Sé era consistentemente a favor da participação de Estados no processo de paz e a Comunidade foi capaz de acolher a sugestão, incluindo os canais formais, adequadamente conforme a evolução do processo permitia. (p. 91)

A abertura para o ocidente com o objetivo de trazer Moçambique para mais perto da Europa e Estados Unidos iniciou-se após a eleição de Joaquim Chissano como novo presidente moçambicano. A aproximação mostrou-se muito relevante para a manutenção da possibilidade do contato direto entre a FRELIMO. As participações e pressões dos atores externos tiveram grande impacto na redução das chances da continuidade das hostilidades, ao mesmo tempo em que ofereceram alternativas para os problemas graves em termos de segurança física, estratégia militar, interação política e reconhecimento internacional. (ver AALL, 2007, p. 486; CHIGAS, 2007, 556; LANZ; SGUAITAMATTI, 2009, pp. 9-10)

O Papa João Paulo II teve duas reuniões com o Presidente Chissano e, em ambas as ocasiões, ele reiterou a necessidade de uma solução negociada para o conflito. A igreja defendeu, por muito tempo, a necessidade de negociações tanto no plano privado como no público. A Comunidade reforçou essa estratégia dupla, tanto diretamente como indiretamente, através do apoio ao trabalho do Bispo Jaime e do Cardeal dos Santos, além de oferecer acesso sem precedentes aos tomadores de decisão europeus. Esta sinergia reforçou a estatura da Igreja em Moçambique e permitiu um papel pró-ativo na defesa de uma solução pacífica do conflito. Desse modo, as forças externas convergiam com as internas para forçar as lideranças a chegar a paz, que já era uma possibilidade. Podemos perceber aqui, uma interação entre diversos atores, que, conjuntamente e pela liderança da Comunidade de Sant'Egidio, conseguiram realizar a mediação do conflito. (pp. 91-92) (ver CHIGAS, 2007, p. 571; NATSIOS, 2007, pp. 344-345)

A Comunidade de Sant'Egidio teve um desempenho fundamental no apoio ao envolvimento da Igreja moçambicana, da Itália e do Vaticano no conflito. Este esforço manteve as informações relevantes fluindo e permitiu que os interlocutores se encontrassem pessoalmente. Isso foi essencial posteriormente, pois se estabeleceu um elo entre as iniciativas e reconhecimento formal da comunidade internacional. Esses fatores foram fundamentais para combinar o desejo da RENAMO de pronunciar-se como uma organização política e a recusa 
do governo da FRELIMO em reconhecê-la como tal, abordando-os somente como "pessoas". A Comunidade teve a liberdade, como entidade privada, para interagir em todos os níveis simultaneamente, adotando uma abordagem multicamada, o que o permitia desempenhar o papel fundamental de integração, canalizando orientação que eram latentes na arena política no momento. (p. 92)

A busca pelo começo das negociações de modo confidencial foi necessária em Moçambique devido a dois motivos: primeiramente, porque a RENAMO ainda era considerado um grupo ilegítimo, guerrilheiro, que propagava o terror pelo país; em segundo lugar é consequência do primeiro, pois como a RENAMO não era considerada legítima, a mediação possuía alto custo político. Devido a estes dois motivos a mediação realizada por uma ONG, no caso a Comunidade SantEgidio, era mais propícia, pois não gerava uma legitimação da RENAMO, como ocorreria caso a mediação fosse realizada pela ONU ou por um Estado; e poderia ser realizada mais facilmente em segredo, longe dos holofotes da imprensa nacional e internacional. Outro ponto importante é que, como a RENAMO era considerada ilegítima, os Estados, organizações internacionais ou regionais teriam um alto custo político para negociar com elas e ainda poderia ter o problema do "fator legitimador". (ver CHIGAS, 2007, p. 561; LANZ; SGUAITAMATTI, 2009, p. 5; MITCHELL, 1992, p. 277)

Após tais eventos, em abril de 1990, a Comunidade de Sant'Egídio recebeu o pedido confidencial por parte do ministro da FRELIMO, Aguiar Mazula, para o início da mediação. A proposta consistia em realizar reuniões secretas com a RENAMO sem pré-condições, o que foi um avanço, pois anteriormente a FRELIMO sempre sustentava que a RENAMO tinham que parar antes com a violência e aceitar reunir-se em Moçambique. Em contrapartida, a RENAMO sempre se recusava, temendo por sua segurança e devido ao pedido de ser reconhecida como um interlocutor político. A falta de legitimidade da RENAMO era agravada pela FRELIMO reconhecer a RENAMO somente como um grupo de bandidos armados não-políticos, sem legitimidade e apoio popular, durante muito tempo. Consequentemente, no contexto apresentado, era impossível a sugestão de um possível acordo que reconhecesse a RENAMO como força política. (pp. 91-92) (ver CHIGAS, 2007, p. 563-566; BUTLER, 2009, p. 60; MÜNKLER, 2004, pp. 12-15) 
Para conseguir aprovar o modelo da mediação sugerido e realizar os acordos preliminares para as reuniões secretas, o ministro Mazula reuniu-se com funcionários do Vaticano e políticos italianos, selecionados anteriormente pela Comunidade, ao mesmo tempo em que confidencialmente discutia o formato e conteúdo das palestras com Don Zuppi, membro principal da Comunidade Sant'Egidio, as conversas foram produtivas e o modelo foi apresentado ao Presidente Chissano que o aceitou. Então, a delegação da FRELIMO, composta por quatro representantes, incluindo o ministro Mazula, foi no início de julho para Roma. A participação de diversos tipos de mediadores é interessante para a mediação e a torna mais completa. Pois, nenhum mediador consegue ter todas as características necessárias para fazer toda a mediação e implementação do acordo. No entanto, quando a mediação inclui mais de um mediador e principalmente mais de um tipo de mediador é fundamental que tenha uma coordenação entre eles e todos tenham uma resposta una frente a mediação. Este é o papel da Comunidade Sant'Egídio na mediação de Moçambique. (p. 93) (ver EVANSKENT; BLEIKER, 2003, pp. 107-109)

A realização das reuniões em um território neutro e longe das influências internas de Moçambique e dos seus vizinhos foi importante, pois como mostra a experiência fracassada das negociações de 1984, que congelaram devido à influência da África do Sul e dos comerciantes portugueses, era fundamental retirar os negociadores do conflito e levá-los a um local, onde fossem capazes de experimentar ideias, negociar e estar abertos a outra parte. Ao escolher o local das negociações, a Comunidade estava utilizando os seus poderes para facilitar a negociação e possibilitando um local de baixa pressão tanto por atores externos a mediação como pelos mediadores, como seria o caso de um Estado ou organização internacional estar mediando. Como a Comunidade de Sant'Egídio é uma ONG e consequentemente não defende os interesses dos Estados ou é composta por eles, ela possui a vantagem de conseguir disponibilizar um local mais neutro para as negociações. (p. 93) (ver CHIGAS, 2007, 555-557)

A Comunidade de Sant'Egídio foi considerada segura para as reuniões acontecerem, visto que ambos os lados desejavam encontrar soluções para a paz e tinham estabelecido relações de segurança com a Comunidade, mas não entre si. A Comunidade teve que respeitar a legitimidade do governo e o seu medo de legitimação da RENAMO, enquanto tinha que tranqüilizar a RENAMO quanto a 
sua segurança e a plena troca entre as partes. Durante todo o processo foi feito um esforço para a unidade estar presente em todos os atos, palavras e elementos do processo de modo a refletir em um convite para uma unidade real em Moçambique, e não somente no documento final e nas declarações públicas. (p. 84)

As primeiras reuniões em separado foram tão bem-sucedidas que ambas as partes concordaram em realizar uma mediação formal através de um comunicado conjunto. Durante todo o processo, a Comunidade ajudou no relacionamento entre as partes, incentivando respostas criativas diante de crises desafiadoras, o que foi particularmente importante quando não existiam outras opções disponíveis e concebíveis. A estratégia utilizada em Moçambique pela Comunidade de Sant'Egidio foi a ideal para os conflitos complexos, um estratégia flexível, criativa, adaptável e que respondia às necessidades do conflito de modo rápido e constante. Foi o início do diálogo e do processo de mediação que resultaria na assinatura do Acordo Geral de Roma, em 4 de outubro de 1992, e o fim do conflito. (pp. 92-95) Durante as negociações, a Comunidade utilizou-se do poder informacional, perito e legítimo. (ver AALL, 2007, pp. 481-485)

Um dos papéis desempenhado pelo mediador foi traduzir as mensagens entre as partes, utilizando-se do poder informacional e perito. Desde o início das negociações, as partes tenderam por na aceitar a posição do outro como legítima para o começo do processo, ao mesmo tempo em que saudavam a mesma posição se fosse apresentada por um partido neutro, a posição foi mantida durante todos os momentos da mediação, na fase informal e formal. A Comunidade de Sant'Egídio proporcionou um espaço de comunicação cheio de possibilidades, um microcosmo revelador das possibilidades presentes quando as partes se comprometiam seriamente com o diálogo. O que sensibilizou todos os delegados para a possibilidade de negociações diretas, sendo este o primeiro passo significativo. A constatação de que as negociações eram viáveis e de que era responsabilidade também das partes cresceram ao longo do tempo, e, porque era desenvolvida calmamente e não era imposta, tornou-se essencial durante os dois anos e meio. (p. 97)

A Comunidade envolveu o governo italiano, porque ela não podia fornecer toda a gama de serviços e garantias que a mediação necessitava. A assistência financeira e institucional foi essencial para o sucesso da mediação. (p.97) A falta 
de poder de recompensa, de coerção e até mesmo financiamento para realizar a mediação é uma das principais limitações das ONGs. (CHIGAS, 2007, p. 562; AALL, 2007, p. 486) No entanto, elas podem solicitar a ajuda de outro ator de cenário internacional para suprir esta debilidade, como é o caso aqui retratado. Pode-se perceber, durante a mediação, a combinação organizada de formas entre a Comunidade Sant'Egídio, o Vaticano, a Itália e, posteriormente, a ONU para construir a paz sustentável em Moçambique. Está combinação de forças entre diversos atores é fundamental para a existência coesa e forte de uma mediação, principalmente considerando a complexidade do conflito. É necessário que todos os atores envolvidos na mediação estejam coordenados, pois caso isto não ocorra vai acontecer a fragmentação de autoridade e poder na mediação e o resultado provável é o fracasso de todo o processo. (ver CHIGAS, 2007, p. 571)

Logo no início do processo de negociação, Riccardi deixou claro em seu discurso que o sucesso do processo e consequentemente a implementação do acordo de paz dependiam completamente dos moçambicanos. O tom do discurso conseguiu captar o espírito e a forma de trabalhar da Comunidade. Pois, não era a pretensão deles serem uma presença formal e forte a qual poderia impor uma solução, pelo contrário, a presença deles era baseada em uma teia de relacionamentos estabelecido e cuidadosamente cultivado por meio de contatos pessoais que foram construídos de modo direto e produzindo diálogos. O reconhecimento que todo o processo dependia dos moçambicanos era fundamental, e os observadores e os membros da Comunidade só foram envolvidos quando as partes solicitavam ou sinalizavam a aprovação. (p. 99)

O processo conseguiu diversas vitórias que devem ser destacadas: o reconhecimento mútuo pelas partes, eles enquadraram esse auto-reconhecimento em termos de pertencerem à "família moçambicana", como patriotas; eles desenvolveram um diálogo direto construtivo, solicitando a participação dos observadores na mediação e respondendo criativamente aos obstáculos; o compromisso com a paz foi incorporado em um processo real de reconstrução da sociedade; a comunicação atual como uma ferramenta essencial, sendo uma abordagem flexível indispensável para permitir que o processo conseguisse sucesso completo durante os dois anos em Roma e permanecesse; as partes reconheceram após a primeira reunião direta a necessidade de uma abordagem orientada para o futuro e as mudanças que tinham que ocorrer e que ambas 
precisavam ser flexíveis; e ambas as partes perceberam a necessidade de uma nova reunião para experimentar o potencial das negociações diretas tendo uma equipe como mediadora. A avaliação final da Comunidade de Sant'Egídio quanto a esse encontro foi que ele foi adequado para o momento do processo, teve muitos avanços e foi importantíssimo para começar a fechar o período de conflito e abrir a possibilidade de paz. (p. 100) A Comunidade então avaliava o processo constantemente para saber se os progressos eram válidos e se eles poderiam prosseguir na mediação. (ver JONES, 1999, p. 59; CHIGAS 2007, pp. 555-557)

Ocorreu uma mudança significativa de percepção entre as partes, pois anteriormente elas não consideravam a posição da outra como legítima, a FRELIMO não considerava a possibilidade de negociar com a RENAMO; porém, durante a mediação, conseguiu-se mudar essa percepção e construir outra, na qual todos se viam como pertencendo à "família moçambicana". O mediador tem como obrigação analisar a mudança de perspectiva e decorrente da sua conclusão mudar retrocedendo ou avançando na mediação. A construção da "família moçambicana" tem duas consequências importantes para o processo de mediação: primeiramente é uma forma de reconciliação da sociedade, de desenvolver um sentimento de união e compartilhamento, estes sentimentos serão fundamentais para a construção e fortalecimento do Estado moçambicano, que é a segundo consequência. (ver RICHMOND, 1998, pp. 707, 721; BERCOVITCH; ELGSTROM, 2001, pp. 1,12,15; NATSIOS, 2007, 358)

Em campo fechado ocorreu a transferência de ideias, sugestões e possibilidades entre as partes, sendo que neste momento elas foram julgadas por atores que não possuíam a política como condicionante. A história foi outro fator importante durante o processo de mediação, pois ela foi mantida viva e foi "revisada" em diversos momentos entre os membros da Comunidade e seus visitantes, o que tinha como efeito muito significativo sobre os laços para todos e é esse efeito que explica o quanto foi possível com pouco investimento encontrar aliados inesperados e desenvolvimento um entendimento que todas as partes faziam parte da "família moçambicana".

As "lições" vindas da história foram explicitamente e implicitamente compartilhadas, permitindo a autocompreensão por parte dos atores, os quais acreditavam que a manutenção da história viva possibilitava a ampliação das possibilidades e não permitindo que as negociações caminhassem para a repetição 
automática dos eventos anteriores, mas empurrando os limites da criatividade na criação de respostas coerentes aos novos e únicos desafios. A história tem importância durante a mediação, porque durante o curso dos anos ela tornou-se um patrimônio coletivo, um sacramento de sucesso, devido à captura de sentimento de esperança que o impossível é possível e que certamente o impensável e pensável. A manutenção da história viva permitiu a transferência do conhecimento tornou-se uma alavanca de motivação para um modelo processual construtivo o qual permeou todo o processo de transformação, tornou-se uma “experiência de paz", antes mesmo da paz ser alcançada. (p. 99-101) O aprendizado por meio dos acontecimentos anteriores é primordial para que os erros anteriores não sejam repetidos. Além de conseguir fazer uma leitura dos acontecimentos impedindo que alguma parte se sinta esquecida e não valorizada no processo. Como acontece no caso do Burundi, que será analisado no próximo capítulo.

Durante todo o processo a Comunidade de Sant'Egídio não era uma equipe objetiva, treinada e composta por consultores profissionais, mas o seu empenho real em estabelecer relacionamentos que ajudou as partes apresentarem queixas de maneira construtiva. Enquanto a comunicação era controlada a diferença entre as duas faixas da mediação (oficial e não-oficial) foi menos acentuada, como apresentado por diversos mediadores. Mesmo a resolução dos problemas foi mais devido ao esforço geral, em oposição a uma característica especifica de um determinado encontro. Durante mais de 10 anos e através de numerosos encontros foram debatidas de modo positivo questões estruturais e de liberdade religiosa. Os encontros contribuíram para que o conflito fosse resolvido, pois cada vitória contribuiu para a solução do problema. A falta de comunicação, a necessidade de acesso a novas ideias e a necessidade de novos quadros interpretativos foram abordados continuamente durante o longo processo de mais de dezesseis anos. (p. 102)

Depois de anos de discussão prévia, relacionamentos desenvolvidos e de profundo processo de negociação, o qual durou mais de dois anos foi assinado em 4 de outubro de 1992 o Acordo de Roma, dando fim ao conflito de Moçambique. Após a assinatura do acordo, o Secretário Geral das Nações Unidas apresentou, em 3 de dezembro do mesmo ano, ao Conselho de Segurança um relatório contendo um plano operacional para a operação de paz em Moçambique - 
ONUMOZ. No relatório, Kofi Annan apresentava as dificuldades da operação, nas quais destaca-se: infra-estrutura devastada pelo conflito, o tamanho do país, a economia destruída pela guerra e pela seca, a limitada capacidade do governo em lidar com as tarefas decorrentes do acordo de paz, e a complexidade dos processos previstos no Acordo. O Conselho de Segurança, em sua Resolução S/RES/797 de 1992, aprovou a recomendação do Secretário Geral e estabelecer a ONUMOZ. O Conselho convidou a FRELIMO e a RENAMO para cooperarem de modo pleno com as Nações Unidas, a respeitar o cessar-fogo e as obrigações decorrentes do Acordo, sob a coordenação do Representante Especial Interino. (RESOLUÇÃO S/RES/797)

Apesar de a implementação do acordo não ser o tema principal da dissertação, destaca-se o papel fundamental desempenhado pelo Representante Especial do Secretário Geral da ONU, Aldo Ajello, na ONUMOZ e certamente grande parte do sucesso da operação e o cumprimento dos objetivos da missão foram devido a ele. Ajello foi capaz e disposto a utilizar a força política à sua disposição para levar o processo adiante, contestando a burocracia da ONU e lidando diretamente com as partes moçambicanas. Ajello soube organizar de forma flexível e agressiva o mandato e os recursos disponíveis a ele. Ao mesmo tempo em que as suas habilidades diplomáticas a qual prezava pela cautela e descrição, ele defendia iniciativas ousadas, atuando nas diversas situações. Devido a sua presença no local que ocorreu o conflito as ações de Ajello deram-se em um ambiente mais complexo, com maior perigo e desafios, sendo necessário muitas vezes a tomada de atitude, providencias e ações que eram além dos tratados e papeis, chegando até mesmo a necessitar de ousadia para quebrar regras. (JETT, 1999, pp. 76-80) Ajello não permitiu ficar engessado pelas burocracias, regras e mecanismos da ONU, os quais atrapalhavam a eficácia da ONU e as demais organizações internacionais. Ajello utilizou de criatividade, flexibilidade e se adaptou as situações apresentadas para assim conseguir realizar com eficácia a liderança da ONUMOZ.

\subsection{Conclusão}

O conflito em Moçambique iniciou-se em 1977 depois da criação da RENAMO com o apoio financeiro e militar do Zimbábue. Percebe-se desde já a 
grande influência do regionalismo no conflito, pois mesmo com a insatisfação da população com as mediadas socialistas e incompetentes da FRELIMO só foi possível a criação da RENAMO devido à interferência externa.

Desde a sua independência o governo moçambicano enfrentava dificuldade para administrar a construção do Estado de Moçambique. Mesmo com o auxilio da ex-URSS (União das Repúblicas Socialistas Soviéticas), os líderes moçambicanos eram extremamente despreparados para governar o Estado. O que é comprovado pelas medidas incompetentes adotadas por eles, as quais só pioraram a situação de pobreza e fome em todo o país. $\mathrm{O}$ ataque deles aos líderes e instituições tradicionais fez com que a legitimidade da população, que já era mais relacionada às organizações tradicionais do que ao Estado, fragmentassem mais gravemente e com que as forças que antes se uniram para conquistar a independência se fragmenta-se. Percebe-se então, um grande choque entre a construção do Estado e a autodeterminação; e a incapacidade do Estado em suprir as necessidades básicas da população.

A determinação de um partido único e a falta de instituições de resolução de conflito, sendo que até mesmo as tradicionais foram perseguidas pelo governo, fez com os grupos insatisfeitos não vissem outra saída para que suas reivindicações fossem aceitas do que a luta armada. Ou seja, não existiam meios de resolver os conflitos sociais se não por meio de transformá-lo em conflito armado, na visão deles.

O conflito de Moçambique teve duas forças principais, apesar da existência de milhares de milícias e grupos de proteção, devido a concentração de forças que ocorria durante a Guerra Fria em decorrência do patrocínio e apoio do grupo socialista versus o grupo capitalista, sendo que em Moçambique o grupo socialista era representado pela URSS enquanto o grupo capitalista era composto pelo Zimbábue, África do Sul entre outros.

A Comunidade Sant'Egidio entrou no conflito em 1977 no seu início. Primeiramente o trabalho da Comunidade era focado na ajuda humanitária e em negociações pontuais, os quais posteriormente foram desenvolvendo um relacionamento de confiança entre eles e as partes fazendo com que ela atuasse em outras funções, tal como mediador ativo no conflito.

O longo envolvimento da Comunidade no conflito fez com que ela desenvolve uma rede de conhecimento, que possibilitou um alto conhecimento 
sobre a cultura, costumes, crenças e do conflito. Além disso, possibilitou com que eles conseguissem englobar toda a sociedade no processo de mediação.

A Comunidade também utilizou a rede católica de paróquias e igrejas para conseguir se inserir no conflito, utilizando do seu caráter religioso e da sua proximidade com o Vaticano. $\mathrm{O}$ aspecto religioso foi importante uma identificação com as partes e com a sociedade de modo geral e ajudou na prénegociação com as duas visitas do Papa a Moçambique, que ajudou a chamar a atenção internacional para o conflito e deu mais força a mediação.

A identificação entre a Comunidade, a RENAMO e a FRELIMO não se limitou ao aspecto religioso, mas deu-se por similaridades tribais, como foi o caso do Bispo Gonçalvez e Dhlakama, líder da RENAMO, que pertenciam à mesma tribo e com a identificação entre eles os canais de comunicação ficaram mais abertos, o que foi aproveitado pela Comunidade que tornou o Bispo Gonçalvez o intermediário com a RENAMO. (BARTOLI, 1995, pp.94-95)

Todo o envolvimento da Comunidade com a RENAMO se desenvolveu sendo ela considerada como ilegítima pelo governo moçambicano e internacionalmente. A capacidade de se envolver com atores ilegítimos é fundamental para que a mediação aconteça nos conflitos complexos, pois é fundamental para a mediação que todas as partes participem da mediação. Não era possível desconsiderar a RENAMO nas negociações e caso um Estado ou a ONU fizessem esta negociação teriam que pagar um alto custo político para considerar este ator.

Outro ponto que agravava o relacionamento com os atores ilegítimos do conflito era o desrespeito aos direitos humanos e o ataque aos civis como arma de guerra. O governo da FRELIMO e a RENAMO utilizavam-se de ataques a civis como forma de propagar o medo no território fazendo com que o envolvimento com eles fosse ainda mais preocupado para a ONU e os Estados, devido ao custo político.

A Comunidade também fez todo um trabalho para desmitificar o "outro" como inimigo mortal ou terrorista. Esta ação foi muito bem-sucedida e conseguiu que no final da mediação todas as partes se viam compondo a "família moçambicana" que possuía memórias comuns e formavam uma comunidade estatal. 
A mediação de Moçambique teve a participação de outros atores, tais como o Vaticano, o governo italiano e a Organização das Nações Unidas, que estabeleceu a missão de paz para Moçambique. A Comunidade conseguiu coordenar o trabalho desses atores, fazendo com que todos concentrassem-se no mesmo objetivo e respondessem quando fosse solicitado por ela, fazendo assim que não ocorresse competição entre eles e que as partem mudassem de mediador para pressioná-los.

O objetivo da mediação em Moçambique não se limitava a assinatura do acordo de paz, ao contrário, eles compreendiam que a real resolução do conflito quando resolvessem as suas causas reais. Inclusive, a Comunidade está presente em Moçambique até hoje com projetos na área de saúde, desenvolvimento e combate a pobreza, o que é uma das vantagens das ONGs, as quais na maioria das vezes permanecem no país depois da resolução do conflito e por isso têm o interesse de realmente resolver o conflito. 


\section{5. \\ Aceh}

O Conflito do Aceh iniciou-se em 1976, depois que empresas norteamericanas começaram a explorar o gás natural da região. O Movimento do Aceh Livre (GAM) declarou que o governo da Indonésia não estava transmitindo os ganhos do gás corretamente para a região e, devido a diferenças religiosas e culturais, reivindicaram a separação da Indonésia. O GAM utilizava-se de estratégia de guerrilha e violação aos direitos humanos nos seus ataques, em contrapartida, o governo enviava o exército que também violava os direitos humanos e atacava a população.

Duas rodadas de mediação para o conflito foram tentadas. Na primeira rodada, a ONG Henry Dunant Center for Humanitarian Dialogue foi a principal mediadora. Essa mediação, que iniciou-se em 2000, no entanto, não foi bemsucedida, apesar de ter conseguido alguns ganhos como a "pausa humanitária", a qual foi violada inúmeras vezes.

A segunda rodada de mediação iniciou-se após o Tsunami de 2004 devastar a população e encontrou as partes mais interessadas na mediação, acreditando que a solução pacífica do conflito era a melhor alternativa. O cenário internacional também era diferente. O Tsunami tinha chamado a atenção internacional para a região e os Estados e organizações internacionais estavam mais propensos a interferir no conflito, apoiando a ação da Conflict Management Initiative, que era a mediadora principal.

\subsection{Henry Dunant Center for Humanitarian Dialogue}

O Henry Dunant Center for Humanitarian Dialogue (HDC) é uma organização independente de mediação sediada em Genebra. (AALL, 2007, p. 478) Iniciou suas operações em agosto de 2005, dedicado-se a melhorar a resposta global ao conflito com presença na América do Norte, Europa, Ásia e África. Como uma organização neutra e imparcial, a sua missão é apoiar apenas soluções que ofereçam a melhor perspectiva de uma paz justa e duradoura, em consonância com o direito internacional. Objetivando contribuir para os esforços de melhorar a resposta global ao conflito armado. Defendendo que o diálogo baseado em 
princípios humanitários pode auxiliar na realização de acordos políticos, e que as iniciativas informais realizadas por uma fundação privada pode ser complementar a diplomacia formal, contribuindo assim para a solução pacifica do conflito. Para alcançar esses objetivos eles utilizam a mediação entre as partes em conflito e o apoio à comunidade mais ampla da mediação. (HENRY DUNANT CENTER FOR HUMANITARIAN DIALOGUE SITE)

O HDC busca cumprir os seus objetivos comprometendo-se com novas abordagens, para a aprendizagem e a colaboração, trabalhando com os outros para além das fronteiras, crenças e profissões. Comprometendo-se e promovendo ações para prevenir e resolver conflitos armados, apoiando de forma personificada os processos de paz, nos quais a sua participação agregue valor, incluindo: (1) facilitar o diálogo entre as partes, fazendo o papel de mediador caso necessário; (2) assegurar que as partes são capazes de participar efetivamente das negociações; (3) mobiliar respostas humanitárias, diplomáticas e políticas; (4) contribuir de forma políticas em questões substantivas e relevantes; e (5) fornecer outros serviços especificamente adaptados, como mecanismos de financiamento e apoio logístico, nos quais a assistência de uma fundação privada seja necessária.

A HDC é uma ONG voltada desde a sua criação para a resolução de conflito e é hábil para conduzir a resolução com independência política, imparcialidade, respondendo rapidamente, de modo flexível e criativo, podendo assumir riscos políticos, incluindo as suas redes de conhecimento, principalmente na África e na Ásia para conseguir penetrar no conflito. Outra vantagem que deve ser ressaltada é que a mediação pode ser realizada de forma discreta, longe dos holofotes da mídia, o que abre a possibilidade para a mediação de conflitos, nos quais as partes não podem assumir o custo político de realizar a mediação ou iniciá-la diante do público. Como foi colocado anteriormente, as vantagens apresentadas pelo HDC são as vantagens que as ONGs possuem no papel de mediadoras e por isso conseguem trabalhar em diversos níveis do conflito e atuar em conflitos complexos. (ver LANZ; SGUAITAMATTI, 2009, p. 5; AGGESTAM, 2003, p. 17; AALL, 1996, p. 3; AALL, 2007, p. 477; CHIGAS, 2007, p. 561)

A HDC só conseguiu realizar a mediação no conflito do Aceh devido a características anteriormente apresentadas, pois o Movimento do Aceh livre (GAM) era inflexível em seu desejo de independência para o território do Aceh, 
enquanto o governo da Indonésia não afirmava que aquele território era parte da Indonésia e não aceitava o GAM como sendo um adversário político, mas como um grupo de terroristas, como foi classificado pelos Estados Unidos após o atentado terrorista de 11 de setembro em Nova York. A mediação iniciou com um clima de surpresa, pois a Indonésia não aceitava a interferência no que eles consideravam como uma rebelião interna e ilegal. (HUMBER, 2004, p. VIII) No contexto apresentado, somente a mediação realizada por uma ONG seria possível, devido à possibilidade de realizar a mediação de forma discreta e não tendo uma forte pressão sobre as partes e custos políticos que seriam impossíveis para ambas as partes sustentarem frente à opinião pública nacional e internacional. Os custos políticos também seriam altos demais para outro mediador, com exceção das ONGs, visto que o GAM chegou a ser incluído na lista de associações terroristas dos Estados Unidos da América. Além disso, a Indonésia não aceitaria a mediação de outro tipo, devido à possibilidade das ONGs serem mais discretas e ter menos pressão sobre as partes durante a mediação e para alcançar o acordo. (ver KELMAN, 2000, p. 275)

\subsection{Conflict Management Initiative}

A Conflict Management Initiative (CMI) foi fundada em 2000 por Martti Ahtisaari $^{25}$ em Helsinque. Ele acreditava que a comunidade internacional precisava de um ator independente dos governos, o qual poderia ajudar a atenuar as crises internacionais e reforçar a capacidade operacional da comunidade internacional. A CMI centra-se na construção de uma paz sustentável e na resolução de conflitos, através da mediação, facilitando diálogo de construção de confiança e fortalecendo as capacidades locais para a implementação da paz. Além de apoiar as missões de paz internacional, quando solicitado. (CMI, 2012a)

\footnotetext{
${ }^{25}$ Martti Ahtisaari nasceu em 23 de julho de 1937. trabalhou como diplomata finlandês, ocupando os postos de embaixador na Tanzânia, Comissário das Nações Unidas para a Namíbia, Representante Especial do Secretário Geral para o mesmo país, Secretário-Geral adjunto da ONU, presidente do grupo de trabalho da Conferência Internacional para a ex-Iugoslávia na BósniaHerzegovina, Conselheiro Especial para a Conferência Internacional para a ex-Iugoslávia, Representante Especial da ONU para a mesma região. Foi eleito Presidente da Finlândia em 1994. Como presidente finlandês juntamente com o ex-presidente russo Viktor Tchernomirdin conseguiu convencer o Presidente Iugoslavo, Slobodan Milosevic a por fim às operações militares no Kosovo contra a guerrilha separatista albanesa em troca do fim do bombardeamento da OTAN. Após deixar a presidência finlandesa fundou a CMI. Recebeu o Nobel da paz em 2008 pelo o seu trabalho na resolução de conflitos.
} 
O trabalho da CMI é orientado para os resultados, procurando sempre alcançar a qualidade, eficiência e impacto na mediação e processos de paz. Os membros da CMI não acreditam que os resultados na resolução de conflito são conseguidos sozinhos, mas através da combinação de diferentes habilidades, talentos e recursos, trabalhando por meio da combinação de ação, análise e defesa dos direitos. Eles realizam a mediação de forma participativa e inclusiva, esforçando-se para desenvolver ferramentas baseadas no contexto local, envolvendo todos e procurando desenvolver valores, principalmente para as partes interessadas, as quais podem ser sub-representadas no processo de paz. A CMI procura incluir toda a sociedade no processo, o que é fundamental nos conflitos complexos. Além disso, eles também têm uma ideia ampla quanto à resolução de conflito, não se focando somente no acordo de paz, mas em um amplo programa de cura na sociedade. Sendo que no programa pode participar mais de um ator internacional, ou seja, os Estados e organizações internacionais podem serem incluídos no processo. (ver LEDERACH, 1997; DEBRIX, 1999, p. 196)

A CMI é uma fundação que desenvolve projetos para a paz sustentável e o seu financiamento vem de governos, fundações norte-americanas e européias, organizações e empresas que financiam os seus projetos. Então, o financiamento da CMI é um problema que deve ser questionado, pois não é possível ser considerada uma instituição sem pressão política quando os seus principais financiadores são Estados e instituições governamentais, porque ao financiar os projetos existem interesses por detrás. A CMI está muito próxima do debate sobre a relação do Estado e das ONGs no qual, em muitas situações, os Estados agem indiretamente na resolução de conflitos por meio do financiamento de ONGs, as quais defendem os seus interesses. Não se pode afirmar que este é o caso do CMI, no entanto, deve-se questionar quais são os interesses dos financiadores. O CMI não é a única ONG que se encontra nessa situação, a Comunidade Sant'Egidio, por exemplo, também recebe dinheiro do Vaticano, que é uma instituição religiosa com interesses próprios. (CMI' 2012b) (ver COOPER; HOCKING, 2000, pp. 361365; NATSIOS, 2007, pp. 346-347; EVANS-KENT; BLEIKER, 2003, pp. 107109)

Em 2005 o CMI foi convidado a realizar a mediação do conflito do Aceh entre o governo indonésio e o GAM, depois de uma significativa mudança de contexto interno e externo devido ao Tsunami de 2004 que assolou a região. $\mathrm{O}$ 
CMI conseguiu realizar o acordo entre as partes seis meses depois. (RÁDIO NOTICIAS, 2008)

\subsection{O conflito}

Em 1949, depois de um sangrento conflito civil contra os Países Baixos ${ }^{26}$, a Indonésia conseguiu a sua independência e anexou a região do $\mathrm{Aceh}^{27}$ como província vizinha de Sumatra do Norte. Consequentemente, os cidadãos de Aceh ressentiram-se devido a diferenças étnicas e religiosas entre as regiões - a maioria de Sumatra do Norte é cristã Batak, enquanto a maioria de Aceh é muçulmana. O crescente ressentimento resultou, em 1953, na rebelião islâmica liderada por Daud Bereueh e que teve fim com a assinatura do acordo. (MILLER, 2004)

$\mathrm{Na}$ década de 70 , por meio de convênio com o governo central da Indonésia, petrolíferas americanas e companhias de gás iniciaram a exploração dos recursos naturais na região do Aceh. Contudo, alegando distribuição desigual dos lucros entre o governo central e os nativos de Aceh e influenciada pelo movimento rebelde islâmico, Hasan di Tiro criou, em 1976, o Movimento Aceh livre (GAM) e declarou a independência do Aceh, a qual não foi reconhecida pela Indonésia e iniciou-se um conflito separatista. O conflito do Aceh não possui somente motivação territorial, as reclamações do GAM, a ressurreição sustentada esporadicamente pelo GAM, a qual declara o Aceh independente desde 1976, e das respostas exacerbadas, principalmente militarmente, do governo indonésio, mas também inclui questões econômicas, devido à riqueza produzida, principalmente, pela exploração do gás na região. (SEBASTIAN, 2004) Como colocado no capítulo anterior, a motivação dos conflitos complexos não é somente territorial, mas por questões econômicas e pela falta de representatividade política, como é o caso em Aceh. A situação ainda foi exacerbada devido às respostas

\footnotetext{
${ }^{26}$ A guerra civil pela independência da Indonésia iniciou-se após o fim da Segunda Guerra Mundial. Durante a Segunda Guerra Mundial, o Japão tinha ocupado a ilha (Dower, 1986) e com o fim do conflito, Sukarno, líder indonésio que tinha cooperado com os japoneses, declarou a independência da Indonésia, mas os aliados apoiaram o exército dos Países Baixos e tentaram recuperar a colônia. A guerra pela independência, chamada de Revolução Nacional da Indonésia, durou mais de quatro anos e envolveu esporádico, contudo, sangrento, conflito armado interno, levantes políticos e duas intervenções diplomáticas internacionais. E somente em dezembro de 1949 após pressões internacionais, os Países Baixos reconheceram formalmente a independência da Indonésia. (Taylor, 2003, p. 325)

${ }^{27}$ Aceh é uma região localizada na ponta norte da ilha de Sumatra. A província de Aceh tem a maior porcentagem de muçulmanos no país.
} 
violentas por parte do exército indonésio, o qual não incidia somente os membros do GAM, mas em toda a população do Aceh acentuando o ódio e o medo a Indonésia. (ver CARMENT, 2003, pp. 411-412)

No início do conflito o GAM foi quase completamente vencida pelo governo e, em 1977, pareceu que o governo indonésio tinha conseguido neutralizá-la. Todavia, em 1989, o GAM renovou as suas atividades e se reaparelhou com a ajuda financeira da Líbia e do Irã. Apesar do grupo não conseguir o apoio generalizado da população, suas ações levaram o governo indonésio realizar medidas repressivas na região, a qual foi considerada como “operação militar" de 1991 a 1995. Esta medida conseguiu destruir o GAM como força de guerrilha, mas, ajudou se reerguer com a ajuda da população. A população começou a apoiar o GAM não por defender as suas reivindicações e suas atitudes, como ficou claro pelo baixo apoio no início do conflito, mas em retaliação as atitudes do exército Indonésio. Os ataques do exército Indonésio legitimaram as atitudes e reivindicações do GAM frente à população, além de propagar o medo e o ódio a eles. (ver MÜNKLER, 2004, p. 6)

Em 1997, o caos em Java e o governo indonésio ineficaz devido à queda de Suharto deram vantagem o GAM, o resultou na segunda fase da rebelião, que nesse momento contava com o apoio da população de Aceh. (MILLER, 2004, p. 4) As negociações entre os dois lados, as quais iniciaram-se após a queda de Suharto, em 1997, eram interrompidas sucessivamente e os militares do GAM eram acusados de desrespeito aos direitos humanos. Não era somente o GAM, que praticava ataques a civis, os membros do governo indonésio utilizavam-se destes ataques, além de estratégia de guerrilha, armas leves e armas brancas. Atitudes cuja legitimação se davam devido às atitudes do exército, tendo assim características claras de conflitos complexos. (ver BUTLER, 2009, p. 60; RAMBTHAM; WOODHOUSE; MIALL, 2009, p. 100)

Devido às negociações, o presidente indonésio, Habibie, mandou retirar os militares da região em 1998. A partilha da receita proveniente do gás é um elemento central da oferta do governo de autonomia especial para o Aceh, a qual foi consagrada em lei parcial implementada proposta em 1999 e aprovada em 2001. A nova lei era uma das mudanças significativas que estavam acontecendo no sistema político da Indonésia após a morte de Suharto, o general aposentado 
que comandava o regime autoritário indonésio por três décadas. (HUMBER, 2004, p. VIII)

A fragmentação do conflito é outra característica do conflito complexo, pois além do governo indonésio e do GAM, o conflito ainda possuía milícias, as quais também se utilizavam de armas leves e estratégia de guerrilha e grupos de proteção da região. (ver MÜNKLER, 2004, pp. 15-18) Contudo, também deve-se ressaltar que a principal reivindicação do GAM, a separação do Aceh da Indonésia é uma motivação tradicional de guerra (ver BUTLER, 2009, p. 53), ao mesmo tempo, o complicador econômico é intensificado devido à globalização e ao preço das riquezas do Aceh, como o gás natural.

O Henri Dunant Center for Humanitarian Dialogue (HDC) começou a facilitar as negociações entre o governo indonésio e o GAM de forma inesperada, pois o GAM era inflexível em seu desejo de independência do Aceh, enquanto, o governo indonésio defendia que a região integrante da Indonésia. Além disso, o governo indonésio era bastante hostil à ideia de envolvimento de uma terceira parte no que era considerado como uma rebelião interna e ilegal, apesar do considerável tempo do conflito. A classificação do GAM por parte do governo indonésio era consideravelmente forte, levando o GAM ser classificado como grupo terrorista pelos Estados Unidos da América, e existiram boatos de que ele estava ligado a grupos terroristas internacionais, os quais estariam interferindo no conflito. (AALL, 2007, p. 478)

Pode-se observar que, dentro desse contexto, somente a um mediador de baixo custo político e com um método flexível e não tradicional seria permitido a entrada no conflito pelo governo indonésio, considerando a possibilidade da mediação falhar e a possível depreciação da Indonésia frente à opinião pública nacional e internacional. Por parte do mediador, somente um que tivesse baixos custos políticos conseguiria entrar em contato com a parte altamente ilegítima, a qual já tinha sido considerada como grupo terrorista e possuía acusações de desrespeito dos direitos humanos. Considerando todos esses fatores, somente as ONGs poderiam iniciar o processo de mediação no Aceh. (ver LANZ; SGUAITAMATTI, 2009, p. 5; AGGESTAM, 2003, p. 17; CHIGAS, 2007, p. 561)

Desde o início de 2000, o HDC usava questões humanitárias como ponto de entrada, focando-se em esforços de construção de confiança através de um 
processo de diálogo face a face e pautada na cooperação durante a "pausa humanitária" de 2000 a 2001. A pausa humanitária foi a primeira conquista de negociações do HDC com o GAM e o governo indonésio. (HUBER, p. VIII) A "pausa humanitária", estabelecido pelo Acordo de Cessar Fogo de 2000, trouxe esperança de que o fim do conflito estava próximo para a população do Aceh, apesar das regulares violações sofridas por ela nos dois anos subsequentes. (MÜNKLER, 2004, p. 13)

A aceitação por parte do governo indonésio que a mediação entre ele e o GAM fosse realizada pelo HDC e em sua sede pode ter diversos motivadores, tal qual, a falta de força política do HDC, a baixa influencia da negociação feito pelo mesmo frente a pública nacional e internacional, a falta de história desta organização na mediação internacional, a falta de relações do HDC na região do conflito, entre outras. (AALL, 2007, p. 478) Claramente, nenhum outro tipo de mediador, com maior peso político, conseguiria a permissão para iniciar as negociações nesse momento do conflito, pode-se assim observar uma das vantagens destacadas anteriormente na mediação realizada pelas ONGs. (ver LANZ; SGUAITAMATTI, 2009, pp. 9-10)

Após o primeiro sucesso, o HDC iniciou um processo de "diálogo político", o qual resultou no Acordo para Cessar de Hostilidades (COHA), em dezembro de 2002, o qual é mais robusto que o anterior e determina o cessar-fogo pleno, a desmilitarização e eventuais eleições para a província do Aceh. (AALL, 2007, p. 479) Em complemento, o acordo ainda dava ampla autonomia para a região do Aceh e o direito de estabelecer partidos políticos locais para defenderem os seus interesses frente ao governo indonésio. (MILLER, 2004)

Durante todo o processo, o HDC trabalhou estreitamente com os principais membros do governo indonésio e com lideranças exiladas do GAM em sua sede baseada na Suécia, em complemento a isso, tentou cultivar o processo de paz na sociedade civil do Aceh. Ao longo do processo, o HDC procurou cada vez mais formar aliança com Estados chaves do processo, como a Noruega e os Estados Unidos da América, para garantir o apoio financeiro e político aos esforços. Para tornar mais amplo o interesse em um acordo de paz bem-sucedido e para emprestar mais conhecimento técnico para o processo de diálogo, o HDC constitui um grupo de "homens sábios", o qual consistia de especialistas internacionais que possuíam estatura política considerável e ligações claras com os países 
importantes. O processo de mediação passou por dificuldades, particularmente com o lançamento da grande operação militar por parte do governo indonésio em abril de 2001, o qual era mais uma violação a "pausa humanitária". (HUBER, 2004, pp. VIII-IX) A tentativa de captar países mais poderosos e mais força política e econômica para as negociações é uma das táticas utilizadas pelas ONGs para compensar a sua falta desses poderes. As ONGs utilizam estratégias de ONGs humanitárias para chamar a atenção internacional para o conflito que estão trabalhando e assim conseguir apoio internacional. O apoio pode ser devido ao interesse dos Estados no conflito, mas não no envolvimento direto com a mediação ou devido à pressão da sociedade internacional e nacional que fica sensibilizada com o conflito a que estão assistindo no jornal. (ver STROBEL, 2006; AALL, 2007, pp. 488-489; COOPER; HOCKING, 2000, pp. 368)

Aprendendo com a experiência anterior da "pausa humanitária", a qual teve uma duração curta - de meados de 2000 ao início de 2001 - o HDC propôs um terceiro fiador mais ambicioso, o qual consistia no Comitê Conjunto de Segurança (JSC) que guiava a implementação do COHA a partir de dezembro de 2002, através da presença de observadores militares da Tailândia e Filipinas. (pp. VIII-IX) A HDC continuava a solicitar um maior comprometimento das partes quando elas não estavam conseguindo cumprir a "paz humanitária". O mediador precisa ser flexível e adaptável não somente à dinâmica e às estratégias utilizadas com as partes, mas também em relação à realidade do conflito. Caso as partes não conseguem cumprir um acordo feito anteriormente, o mediador precisa retornar aquela negociação com uma nova abordagem para depois continuar a mediação. (ver NATSIOS, 2007, p. 341)

Devido ao acordo e às negociações, em 2002, foi anunciada a retirada de tropas indonésias do Aceh, no entanto, o cessar-fogo foi quebrado seis meses depois. (AALL, 2007, p. 478) O projeto e o funcionamento do JSC revelaram-se insuficientes para evitar a deterioração por parte do GAM e dos militares da Indonésia, que conseguiram derrubar o COHA em Março-Abril de 2003. (HUBER, 2004, p. IX) O governo indonésio e o GAM foram acusados de utilizar o período de cessar-fogo para reagruparem-se e, em maio de 2003, o governo alegou que era necessário estabelecer uma área de "emergência militar" para conseguir destruir o GAM. (AALL, 2007, p. 478) 
Em novembro de 2003, a lei marcial foi prorrogada por mais seis meses. Como coloca o relatório da Human Right Watch, os militares indonésios cometeram abusos aos direitos humanos generalizados durante a invasão e ocupação da província, que contou com mais de 100 mil pessoas deslocadas nos primeiros sete meses da lei marcial, e execuções extrajudiciais eram atos comuns. (HUMAN RIGHT WATCH, 2003) Como características principais dos conflitos complexos, ambos os grupos utilizaram-se do ataque a civis como estratégia de combate, os combates não foram diretos entre os grupos, foram utilizadas estratégias de guerrilha. (ver BUTLER, 2009, p. 60)

A mediação realizada pelo HDC no conflito do Aceh não foi bem-sucedida e possui algumas falhas que serão analisadas. O primeiro ponto refere-se à questão da maturação do conflito, um questão necessária, mas não suficiente, para a mediação, ou seja, existem outros fatores necessários para a mediação, como colocado no primeiro capítulo (ver BERCOVITCH, 1984; ZARTMAN; TOUVAL, 2007, p. 445), e relaciona-se à vontade das partes em buscar uma solução negociada como alternativa preferível ao aparente doloroso e indeterminado conflito armado, deve-se observar ainda que a maturação do conflito não é estático, mas muda durante o processo de mediação e o mediador deve estar atento e analisando essa variação. No conflito do Aceh, a dinâmica política, dentro e fora da Indonésia, modifica-se significativamente entre o final de 1999 e o início de 2002. Não está claro se o conflito, mesmo que maduro no início, continuaria favorável para a resolução em face de intransigência do GAM e dos militares indonésios em questões chaves. (HUBER, 2004, p. IX)

Em dezembro de 2002, as partes não estavam prontas para continuar o processo de cessar-fogo, principalmente se considerarmos as diversas interrupções no cessar-fogo estipulado pela "pausa humanitária", o aumento significativo dos militares no Aceh em 2001 e a queda do World Trade Center, que colocavam o GAM como grupo terrorista e davam maior legitimidade para as ações da Indonésia contra eles. O GAM não estava disposto a trocar a sua reivindicação pela independência para um compromisso com a autonomia especial dada o Aceh e continua em questão o desarmamento. O governo indonésio e as forças de segurança também não foram capazes de entregar as profundas reformas que eram necessárias para a paz com Aceh e a sua autonomia especial ser viável no curto e médio prazo. Os beligerantes enfrentaram pressão insuficiente para mudar sua 
posição de impasse frente ao adversário, da sociedade civil nacional e da opinião pública, elite ou de atores internacional. (p. 3) Em algumas situações, os poderes de barganha e coerção são necessários, como na capacidade de acelerar a maturação do conflito ou incentivar as partes a entrar ou manter a negociação. (ver CHIGAS, 2007, p. 562; AALL, 2007, 486; KELMAN, 2000, p. 275)

O HDC não conseguiu extrair concessões significativas de ambos os partidos, tais como a renúncia por parte do GAM, a reivindicação da independência do Aceh e, do governo indonésio, uma proposta concreta de autonomia ou instalação de uma liderança provincial mais aceitável. Para conseguir que as medidas políticas de autonomia para o Aceh fossem cumpridas e realizadas de forma satisfatória, o HDC tinha que ao menos conseguir que um governo provisório fosse instalado em nível provincial ou sub-nacional com lideranças que tivessem a confiança do GAM e da população do Aceh. No entanto, o HDC estava relutante em utilizar-se da sua principal fonte de ameaça/alavanca que era a de retirar os seus serviços como mediador, o que ecoaria aos doadores e colocaria que o HDC tinha um papel valioso no conflito, o qual seria difícil de substituir, essas atitudes dariam uma maior força política para o HDC. (pp. 70-71) Os poderes de coerção e barganha seriam úteis para incentivar uma maior abertura das duas partes na negociação. Ao mesmo tempo, em que poderia fazer com que as partes só aceitassem as propostas do mediador devido ao medo da coerção ou visando ganhos econômicos, o que distinguiria completamente do objetivo da mediação. (ver CHIGAS, 2007, p. 562; AALL, 2007, p. 486; LANZ; SGUAITAMATTI, 2009, pp. 9-10)

O segundo ponto é sobre os limites para o HDC e o que ele, ou qualquer outra organização não-governamental semelhante sem autoridade formal, poderia fazer para garantir um acordo bem-sucedido em conflitos semelhantes. No conflito do Aceh, o HDC utiliza-se de estratégias diferentes, incluindo a criação de um grupo de destaque internacional, "sábios", para mobilizar políticos influentes e o apoio entre os Estados para uma solução bem-sucedida; no entanto, os países doadores, em última análise, evitaram se responsabilizar pelo processo de paz.

A falta de vontade dos Estados em se envolverem diretamente não foi devido à vontade do HDC, o HDC possuía vontade de captar o apoio de Estados para a mediação, mas os Estados e a ONU não estavam interessados em 
implementar a mediação, principalmente em um país tão próximo ao Timor Leste, o qual era uma das principais ações da ONU no momento. Agravando a situação, o presidente indonésio era contrário a qualquer envolvimento formal de uma organização internacional e dos países doadores com responsabilidade direta na implementação, deixando assim, o HDC - e o JSC - sem autoridade política suficiente. A entrada de observadores militares da Tailândia e Filipinas já tinha sido uma concessão considerável para o governo indonésio. (p. 11) Uma das principais vantagens das ONGs é se envolver em conflitos que não despertam interesse dos Estados e das organizações regionais, como o HDC fez no Aceh. No entanto, em algumas situações, as ONGs precisam angariar apoio internacional de Estados, organizações internacionais ou regionais para o conflito, para conseguir colocar mais peso político, obter ajuda financeira, militar ou na implementação do acordo, como seria possível com uma Missão de Paz da ONU. O HDC tentou obter o apoio em duas situações com o grupo dos "sábios" e no JSC, mas não foi bem-sucedido em nenhuma das duas tentativas. (ver LANZ; SGUAITAMATTI, 2009, pp. 9-10; AALL, 1996, p.3; AALL, 2007, p. 477; CHIGAS, 2007, p. 561)

O terceiro ponto aborda uma série de alternativas que o HDC optou por não utilizar e que poderiam fornecer importantes subsídios para as tentativas de resolução, como aconteceu em alguns conflitos semelhantes. A primeira questão é sobre o desenvolvimento analítico, capacidade de aprendizado e aprendizagem institucional, o HDC tinha que analisar o conflito de forma periódica, pois a estrutura do conflito e as necessidades deste frente ao mediador mudam, ou seja, o mediador também tem que se revisar periodicamente para conseguir atender às novas exigências do conflito. Como colocado no primeiro capítulo, as perspectivas mudam durante a mediação e o conflito; em vista disso, é necessário a análise constante por parte do mediador. (p. 43) (ver AGGESTAM, 2003, p. 17; RICHMOND, 1998, pp. 707-721; BERCOVITCH; ELGSTÖM, 2001, p. 12)

A segunda questão aborda a necessidade do mediador de identificar, enquadrar e sequenciar as questões de negociação, pois faz parte da estratégia do mediador estipular e modificar a agenda de negociação de forma que assuntos que estão travados à negociação possam ser entremeados por assuntos de maior consenso e que caso tenham algum retrocesso no campo do conflito, o debate volte para a questão anterior. Não é aceitável que, enquanto a "pausa humanitária" esteja sendo sistematicamente quebrada, se busque aumentar o compromisso entre 
as partes sem uma base de ação fortificada. A terceira questão é que o mediador deve saber lidar com os problemas de representação e de coerência entre as partes, não é aceitável que em uma negociação uma das partes ou todas prometam algo na mesa de negociação e no campo do conflito suas atitudes sejam opostas, ou seja, não é possível que um membro do governo esteja negociando o cessar-fogo, enquanto o governo aumenta as suas tropas militares no Aceh em 2001, a atitude correta seria a retirada das tropas, o que só aconteceu em 2002 e teve a duração de menos de seis meses. (ver BERCOVITCH; HOUSTON, 1998, p. 28; tópico 2.2.8.)

A terceira questão é a necessidade de trabalhar com a sociedade civil, isso quer dizer que o HDC deveria trabalhar também com grupos importantes, mas que não estão necessariamente representados na mesa de negociação, como a sociedade civil e grupos de fora do governo. Ressalta-se que, ao não fazer essas relações secundárias, o HDC esteja perdendo a principal vantagem do mediador de organização não-governamental, que é a possibilidade de estar presente em todos os níveis do conflito, podendo circular desde os membros principais do governo até lideres locais, sendo estes ligados a grupos legítimos ou não. Outro ponto em destaque é que esta fluidez entre os níveis do conflito é fundamental em um conflito complexo, no qual toda a sociedade é atingida e é necessário refazer as relações de confiança e legitimidade em todos os níveis. (ver LEDERACH, 1997; NATSIOS, 2007, pp. 341-344; CHIGAS, 2007, p. 555; CREEKMORE; TAUBEE, 2003, p. 158)

A quarta e última questão é do mediador gerenciar o ritmo de negociação, a partir de análises periódicas feitas por ele. Esse ponto claramente não foi feito corretamente pelo HDC, eles prosseguiram com a mediação solicitando mais compromisso das partes, quando ambas não estavam dispostas a ceder nas suas principais reivindicações. (ver tópico 2.1.3; NATSIOS, 2007, p. 341)

Além disso, a percepção a partir do processo de negociação do conflito, deve-se aprender uma grande lição com a quebra do COHA, que os acordos de paz, geralmente, não são auto-executáveis e exige um terceiro fiador credível. Principalmente, se o cessar-fogo é tão precário como o COHA, o qual estabelece um processo de construção de confiança, na esperança de produzir um acordo sobre questões políticas. (HUBER, 2004, pp. 3- 5) Devido a isto, era necessário que tivesse mais peso político no acordo final e foi a tentativa do HDC com o 
JSC, a qual não foi bem-sucedida. (ver COOPER; HOCKING, 2000, pp. 361-363;

AALL, 2007, pp. 488-489)

A eleição de um novo presidente indonésio, em 2004, trouxe outra rodada de esperança para a realização do conflito, pois este estava desejoso pelo fim do conflito e mostrou-se disposto a entrar em negociação. Nesse momento, parecia que as duas partes, exaustas pela luta, reconheciam que poderiam resolver melhor as suas questões na mesa de negociação. (ver ZARTMAN; TOUVAL, 2007, p. 445; BERCOVITCH, 1984) No entanto, a guerra ainda permanecia quando a ilha foi fortemente atingida pelo tsunami de 26 de dezembro de 2004. Com o tsunami, as negociações, agora tendo como mediador a Conflict Management Initiative, foram ampliadas consideravelmente, devido à atenção sem precedente que o desastre atraiu para o conflito. (AALL, 2007, p. 279)

\subsection{A resolução}

A segunda rodada de mediação foi realizada por uma segunda ONG, Conflict Management Initiative (CMI), a qual realizou cinco rodadas de negociação no primeiro trimestre de 2005, as quais primeiramente tinham o objetivo de facilitar as primeiras conversações entre o Governo Indonésio e o GAM na sequência do desastre causado pelo tsunami de 2004. (p. 479) A primeira rodada de conversação foi realizada em Helsinque ${ }^{28}$, entre 12 e 16 de abril de 2005, pela Conflict Management Initiative e pelo seu presidente, Martti Ahtisaari, foi a primeira vez desde maio de 2003 que as partes se encontravam pessoalmente. A segunda rodada de negociação aconteceu entre o dia 21 a 23 de fevereiro de 2005, a terceira entre os dias 12 e 16 de abril e a quarta nos dias 26 a 31 de maio de 2005. Entre a quarta e quinta rodada o CMI preparou um Projeto de Memorando de Entendimento, o qual formou as bases de discussão para a quinta rodada, que aconteceu entre 12 e 17 de julho. (CMI, 2012b) A última rodada conseguiu com que as partes chegassem a acordos significativos, inclusive após esta os representantes das duas partes deu uma declaração conjunta, na qual:

\footnotetext{
${ }^{28}$ Helsinque é a capital da República da Finlândia com aproximadamente 560 mil habitantes e é a maior cidade do país.(City of Helínque. Site dispon[ivel em: < http://www.hel.fi/hki/Helsinki/en/Etusivu> Acessado em: 5 de fevereiro de 2012.)
} 
"confirmam o seu empenho para a solução pacífica, abrangente e duradoura para o conflito em Aceh com dignidade para todos. As partes comprometem-se a criar condições nas quais o governo do povo do Aceh possa manifestar-se através de processo justo e democrático dentro do Estado unitário e da constituição da República da Indonésia. As partes estão profundamente convencidas de que somente a solução pacífica para o conflito vai permitir a reconstrução do Aceh após o tsunami de 26 de dezembro de 2004, para progredir e ter sucesso. As partes envolvidas no conflito comprometem-se a promover a confiança mútua." (Governo da Indonésia - GAM 17.07.2005)

Percebe-se, na declaração conjunta, a total crença das duas partes de que a solução pacífica era a melhor alternativa para o conflito,ou seja, as partes estavam abertas à negociação e, consequentemente, mais dispostas a fazer concessões nas suas reivindicações iniciais. Nessa situação, o mediador possui mais margem de manobra durante a mediação. (ver RICHMOND, 1998, p. 707; BERCOVITCH, 1984, ZARTMAN; TOUVAL, 2007, p. 445; CHIGAS, 2007, pp. 559-560)

$\mathrm{O}$ acordo foi assinado em 15 de agosto de 2005 na cidade de Helsinque, o Memorando de Entendimento (Memorandum of Understanding) abrange os seguintes tópicos: direitos humanos, anistia e reintegração na sociedade, mecanismos de segurança, criação do observatório Aceh Missão e solução de controvérsias e, a medida das mais importantes, a governabilidade do Aceh incluindo uma lei sobre o governo de Aceh, a sua participação política e econômica e o Estado de direitos. (AALL, 2007, p. 479) O governo da Indonésia convidou a União Européia e cinco países da ASEAN para realizar a Missão de Vigilância no Aceh (MVA), com o objetivo de monitorar e implementar o acordo. O MVA foi implantado em 25 de setembro de 2005 pela União Européia, Noruega, Suíça, Tailândia, Filipinas, Singapura, Malásia e Brunei. A posição do governo indonésio codificou-se completamente frente a primeira rodada de mediação. Enquanto naquele momento o governo não aceita a interferência de nenhum Estado ou organização internacional com mais poder na região, na segunda rodada de mediação o governo convidou outros Estados a participar. O convite da Indonésia aos Estados fez com que eles tornassem-se mais propensos a participar da mediação, pois os custos políticos deles intervirem nas negociações, quando são convidados pelo governo em contrapartida de quando eles têm conhecimento de que o governo não aceitaria a intervenção é bem diferente. (ver CHIGAS, 2007, p. 561) 
O acordo conseguiu que o GAM abdicasse da sua demanda de independência em troca de autonomia para a província e o direito de organizar-se politicamente. Sendo assim, durante o Comitê de Transição os rebeldes do GAM formaram o partido político Partai Aceh (PA) e outros cinco partidos locais que logo tornaram-se presentes em toda a região. (BATER, 2009) A fragmentação do GAM em seis partidos políticos mostra que a fragmentação das forças não é presente somente em diversos grupos armados, mas dentro dos grupos também existem divergência de opiniões e interesses. Por isso, é necessário que se analisem as forças e perspectivas dentro dos grupos, para assim conseguir entender a real organização delas. (ver RICHMOND, 1998, p. 710-713)

$\mathrm{O}$ acordo conseguiu, em seu primeiro ano, que o governo indonésio retirasse parte das forças militares e policiais do Aceh, e que o GAM realizasse o seu desarmamento e desmobilizasse os seus soldados em um processo paralelo à retirada das forças militares e policiais do governo. O acordo ainda conseguiu concessão de anistia aos membros do GAM e os presos políticos e uma nova lei para o governo do Aceh. O GAM concluiu a entrega das armas e o governo indonésio a retirada das tropas do Aceh em 31 de dezembro de 2005, como havia sido acordado no Memorando de Entendimento.

A CMI também se envolveu na fase de implementação do acordo por meio do mecanismo de solução de controvérsias presentes no Memorando de Entendimento, o qual estabelecia que o Presidente do Conselho da CMI seria chamado para se pronunciar em disputas que não pudessem ser resolvidas entre as partes e o Chefe da Missão de Vigilância. Como colocado anteriormente, uma das vantagens das ONGs é que elas, na maioria das vezes, não se retiram da região do conflito após a assinatura do acordo. Pelo contrário, elas são atores frequentes na implementação dos acordos e nas missões de paz da ONU. Essa medida foi tomada para conseguir resolver por meios pacíficos, visto que o conflito é normal em uma sociedade e é necessário que o Estado saiba lidar com ele. O conflito armado é somente um dos tipos de conflito existente na sociedade e, normalmente, decorre de um conflito social que não foi resolvido. (ver WALLENSTEEN, 2002, p.61)

O processo de negociação teve o apoio financeiro do Fundo Europeu da Comissão de Mecanismos e Reação Rápida e do governo holandês e o financiamento e o apoio do governo finlandês. Finalizando a primeira parte do 
processo de implementação, em 11 de julho de 2006, foi aprovada pelo Parlamento da República da Indonésia a nova Lei de Administração do Aceh. Em oposição ao que aconteceu na primeira mediação, os Estados estavam interessados na mediação, além da CMI ter um relacionamento mais próximo dos governos e instituições governamentais. O apoio dos Estados se deu no apoio e suporte financeiro a CMI, assim como aconteceu com a Comunidade Sant'Egidio em Moçambique, toda a mediação foi coordenada pela CMI, a qual conseguiu captar o apoio a ela e a mediação. $\mathrm{O}$ apoio dos Estados deu-se devido à atenção recebida por pelo conflito do Aceh depois do Tsunami de 2004, mas também devido ao conhecimento da CMI dos meios burocráticos dos Estados para conseguir o financiamento estatal. (NATSIOS, 2007, pp. 346-347)

Ressalta-se que a segunda rodada de negociações possuía diferenças significativas em relação à primeira rodada. Primeiramente, a CMI contou com um apoio internacional muito mais significativo do que a HDC devido ao tsunami de 2004, que chamou a atenção internacional para o conflito em Aceh. Segundo lugar, a situação no conflito era diferente, os dois grupos estavam dispostos a negociar e repensar as suas reivindicações, por causa da destruição causada pelo tsunami e do desgaste do conflito. E por último, a CMI era uma instituição mais reconhecida e estruturada do que o HDC para realizar a mediação.

Em 09 de abril de 2009 a Indonésia realizou a sua terceira eleição legislativa desde o colapso da Nova Ordem de Suharto, eram as primeiras eleições legislativas após o conflito do Aceh. A grande preocupação era que o GAM pudesse solicitar novamente a independência do Aceh, principalmente se ele tivesse uma expressiva vitória nas urnas. As preocupações com a eleição foram agravadas devido ao aumento da violência na região. No entanto, apesar da vitória do PA principalmente no litoral, ela não foi tão expressiva quando imaginado e em outras regiões do Aceh outros grupos políticos, sendo alguns dos antigos membros do GAM, ganharam e a reivindicação por independência não foi colocada em pauta novamente. (BATER, 2009)

As novas eleições para o governador da província em 09 de abril de 2012 foram marcadas por mais violência. A principal tensão é entre os ex-lideres do GAM e com os apoiadores de Yusuf, ex-governador da província. A eleição foi ganha por Zaine Abdullah, ex-membro do GAM, que utilizou todo o aparato do GAM para conseguir angariar votos até nas menores vilas. Apesar dos picos de 
violência durante a campanha eleitoral, o que é um sério problema a ser resolvido e que preocupou o governo central da Indonésia, a retirada da campanha eleitoral da reivindicação por independência é um ganho do processo de paz. A aceitação do GAM em realizar disputas políticas e de que faz parte da Indonésia é um avanço. Por outro lado, a disputa eleitoral envolta de violência é uma preocupação que deve ser resolvida ou pode encadear um novo conflito.

\subsection{Conclusão}

Em 1976 começou o conflito o Aceh com motivação política e econômica fortíssimas. O conflito começou realmente depois que empresas norte-americanas começaram a explorar o gás natural na região a partir de reclamações da população de que o valor destinado para a região em recorrência da extração não estava sendo repassado. No entanto, a insatisfação da região tem origem antes dessa época, desde a independência da Indonésia a anexação da região que a população do Aceh reivindica a independência, contudo, essa reivindicação ganhou força devido a motivação econômica e foi formado o Movimento do Aceh Livre (GAM). Como colocado no primeiro capítulo a motivação econômica é um das motivações recorrentes nos conflitos complexos.

O GAM utilizava recorrentemente de estratégia de guerrilha, ataque a civis e violações dos direitos humanos, contudo, o governo indonésio respondia com mais violência, desrespeito aos direitos humanos e ataque a civis. As respostas desproporcionais dadas pela Indonésia fez com que as ações do GAM fossem legitimadas perante a população do Aceh, que começou a apoiar o movimento.

Duas rodadas de mediação foram realizadas no conflito do Aceh em situações completamente diferentes no que diz respeito ao contexto interno e externo. A primeira rodada de mediação foi realizada pela ONG Henry Dunant Center for Humanitarian Dialogue. A mediação iniciou-se em 2000 e foi malsucedida, apesar de ter conseguido um acordo de "pausa humanitária", esta foi violada diversas vezes.

O governo indonésio só aceitou que a mediação fosse realizada pela Henry Dunant Center (HDC) devido a falta do poder coercitivo e econômico por ela e por não possuir alto nível de relacionamento na região. No entanto, essa falta de 
relacionamento na região e dentro do conflito fez com que o mediador tivesse menos poder de manobra e conseguisse compreender profundamente o conflito.

A falta dos poderes de coerção e econômico são agravados pela não maturação do conflito para a mediação, ou seja, as partes não estavam preparadas para a mediação e o mediador não possuía recursos para incentivá-las na mediação. A consequência foi que a "pausa humanitária" que foi conseguida pela HDC foi violada enumeras vezes pelas partes por não ter força política. A HDC tentou colocar mais peso político no acordo e na mediação com o grupo dos "homens sábios", o que não bem-sucedido até mesmo por causa do desinteresse internacional. (HUBER, 2004, p. IX)

As ONGs de resolução de conflito muitas vezes utilizam-se de técnicas das ONGs humanitárias para angariar apoio internacional, todavia, a HDC não conseguiu apoio internacional, principalmente devido a missão de paz da ONU no Timor Leste, que na época era a maior do mundo. O regionalismo aparece neste caso como uma barreira para a resolução do conflito, visto que existia uma grande comoção internacional dirigida a outro conflito próximo.

A falta de conhecimento profundo do conflito, das partes e da sociedade foi provavelmente uma das razões para que a HDC exigisse mais comprometimento das partes, quando elas não estavam cumprindo os acordos anteriores.

A segunda rodada de mediação foi realizada pela Conflict Management Initiative após o tsunami de 2004, que deixou aproximadamente 190 mil mortes no Aceh e devastou a região. O resultado desse desastre é que a atenção internacional estava voltada para o conflito e as partes estavam dispostas a negociar, devido a destruição da região. Sendo assim, a situação encontrada pela CMI é completamente diferente da HDC.

A CMI conseguiu o apoio internacional devido a mobilização após o tsunami e em decorrência do seu relacionamento próximo com doadores governamentais. Os principais doadores da CMI são Estados e organizações governamentais, o que faz com que as suas motivações para entrar no conflito sejam questionadas. Em contrapartida, ela conhece melhor os mecanismos burocráticos para conseguir apoio econômico e político para determinado projetos dele. Consequentemente, a mediação do CMI no Aceh conseguiu o apoio de países da região e da União Européia. A CMI conseguiu coordenar o trabalho 
desses atores brilhantemente, fazendo com que eles entrassem na mediação no momento necessário para responder alguma necessidade do conflito e de acordo com as possibilidades do mediador. Para não sofrer com a falta de peso político a União Européia e cinco países da ASEAN formaram a Missão de Vigilância no Aceh (MVA), que teve a função de monitorar os avanços da implementação do acordo.

No entanto, esses atores que se envolveram indiretamente na mediação iriam sofrer muitos custos políticos para conseguir envolver-se diretamente, pois o GAM era considerado completamente ilegítimo pela Indonésia e tinha sido incluído na lista de organizações terroristas e era associado a uma rede internacional de terrorismo. Sendo assim, o melhor ator para mediar este conflito são as ONGs, devido ao seu baixo custo político.

Nas negociações a CMI conseguiu que as partes saíssem das suas reivindicações inegociáveis. O GAM aceitou abrir mão da independência em troca a autonomia para a província e o direito de se organizar politicamente, fazendo assim com que o conflito transforme-se de armado para político.

Não deixando de pensar no futuro, a CMI continuou no Aceh com o projeto de implementar instituições de resolução de conflito, abrindo assim locais para a resolução pacifica dos conflitos sociais. 


\section{6. \\ Burundi}

O conflito do Burundi iniciou-se em 1972, com o primeiro genocídio de Hutus. Apesar de o conflito só ter reiniciado em 1988 existem fortes ligações entre os dois conflitos e indícios claros de que, na realidade, as tensões do conflito de 1972 não deixaram a sociedade, só foram encobertos pela dominância esmagadora Tutsi.

O conflito foi mediado por três ONGs, na realidade, atuando de formas diferentes durante toda a mediação. A Comunidade Sant'Egidio estava inserida dentro da mediação principal, apesar do mediador principal ser Julius Nyerere, expresidente Tanzânia, e posteriormente, Nelson Mandela. Já a Center for Conflict Resolution e o Search for Common Ground tiveram uma participação que se pode considerar como de segunda via, apesar de realizar uma negociação secreta entre o governo e o CNDD-FDD com mediador principal, mas fora da mediação oficial.

\subsection{Center for Conflict Resolution}

O Center for Conflict Resolution (CCR) é uma organização sul-africana que desempenha o papel de liderança na contribuição da resolução de conflitos e redução da violência na África. O CCR foi estabelecido pela University of Cape Town (UCT), na África do Sul, em 1968 como Abe Bailey Institute for Intergroup Studies (Instituto Abe Bailey de Estudos Intergrupos). Em 1994, tornou-se o Center for Conflict Resolution, o qual possui o objetivo de estudar sobre as relações inter-raciais e a consolidação da paz em toda a África. O CCR construiu nas últimas décadas a sua reputação internacional por excelência e uma sólida experiência em treinamento, mediação e desenvolvimento e pesquisa de políticas,

atualmente eles possuem teorias fortes sobre resolução de conflito e as particularidades dos conflitos africanos e étnicos. (CENTER FOR CONFLICT RESOLUTION $\left.{ }^{a}\right)$

O CCR especializou-se na gestão de conflito, capacitação, prevenção e resolução. Em decorrência, trabalha proximamente de organizações internacionais, regionais e programas no continente africano. O ranking 2011 Global Go to Think Tank Ranking realizado pela Universidade da Pennsylvania 
classificou a CCR como única instituição africana no top 50 non-US Think Tanks Globally. O CCR é classificado como o segundo lugar no top 25 Think Tanks in Sub-Saharan Africa.

O CCR visa contribuir para a paz justa e sustentável na África através da promoção de abordagens construtivas, criativas e cooperativas para a resolução de conflito por meio da formação e desenvolvimento de políticas, pesquisas e capacitação. (CENTER FOR CONFLICT RESOLUTION ${ }^{\mathrm{b}}$ ) Os projetos do CCR na África podem ser divididos em duas categorias: a intervenção no conflito e o apoio a projetos de consolidação da paz (CIPS Programme) e a política de desenvolvimento e projetos de pesquisa (PDR Programme). O primeiro é direcionado para a formação de apoio regional e capacitação do projeto por meio de suporte técnico e treinamento a nível nacional, regional e instituições continentais quanto aos quatro eixos temáticos, direitos humanos e gestão de conflitos; gênero e construção da paz; intervenções sustentadas e alerta precoce de conflitos e respostas. Através dos temas apresentados, o CCR vem trabalhando extensamente com a Comunidade de Desenvolvimento Sul Africano (SADC), a Comunidade Econômica dos Estados Africanos do Oeste (ECOWAS), a Autoridade Intergovernamental para o Desenvolvimento (IGAD) e a Comunidade Econômica dos Estados Centro-Africanos (CEEAC) além de organizações regionais e nacionais da sociedade civil e redes com o objetivo de desenvolver as suas capacidades de prevenção de conflitos e construção da paz sustentável no seio das comunidades locais. (CENTER FOR CONFLICT RESOLUTION ${ }^{c}$ )

O segundo concentra-se no fortalecimento da União Africana e das Comunidades Econômicas Regionais (CERs), como a Comunidade de Desenvolvimento Sul-Africano, a Comunidade Econômica dos Estados Africanos do Oeste, a Autoridade Intergovernamental para o Desenvolvimento e da Comunidade Econômica dos Estados Centro-Africanos. O programa PDR convoca reuniões de grupos para consultoria na África com aproximadamente 20 a 25 participantes e também organiza seminários de políticos com a participação de 60 pessoas sobre os seguintes temas: consolidação da paz na África Austral e seus desafios; consolidação da paz no pós-conflito; a União Africana (UA), as Nações Unidas (ONU) e a sociedade civil; HIV/AIDS em sociedades pós-conflito; e a construção da paz: relação entre a África e a União Europeia. 


\subsection{Search for Common Ground}

A ONG Search for Common Ground foi criado em 1982 com o objetivo de transformar o modo do mundo lidava com o conflito, buscando soluções cooperativas. O Search for Common Ground utiliza-se de uma abordagem multifacetada, empregando iniciativas de mídia e trabalhando com parceiros locais do governo e da sociedade civil para encontrar meios culturalmente apropriados para fortalecer a capacidade da sociedade em lidar com conflitos de forma construtiva, ou seja, compreendendo as diferenças e agindo sobre os pontos em comum. O Search for Common Ground foi considerado a $52^{\circ}$ melhor ONGs do mundo pelo The Global Journal. (SEARCH FOR COMMON GROUND ${ }^{\mathrm{a}}$ )

Segundo a filosofia do Search Common Ground, a nossa capacidade de lidar com o conflito afeta a forma como lidamos com cada problema que a humanidade enfrenta. O conflito está presente no cotidiano dos problemas globais ou individuais e é fundamental lidar com ele de forma construtiva, fazendo com que a história mova-se positivamente. Ao transformar como as pessoas lidam com o conflito, progride significativamente na resolução dos principais problemas que o mundo enfrenta. (SEARCH FOR COMMON GROUND ${ }^{b}$ )

O objetivo do Search for Common Ground é que indivíduos, organizações, governos e a sociedade respondam às suas diferenças de forma não adversa, sendo que o diferente estimula o progresso social em vez de precipitar a violência. Sendo a abordagem deles é de que o conflito será resolvido pela cooperação com aqueles que discordam e a reconciliação deve ser uma norma nas relações interpessoais e internacionais. $\mathrm{O}$ conceito de reconciliação foi exposto no primeiro capítulo e combina fortemente com a filosofia defendida pelo Search for Common Ground, visto que eles defendem a possibilidade de reconstruir as relações depois de conflitos com a ajuda das partes que estavam em discórdia. (ver NATSIOS, 2007, p. 358)

O objetivo claro do Search for Common Ground é fazer com que se encontre um terreno comum a coisas comuns. A filosofia e o objetivo do Search for Common Ground é a base de onde a mediação parte, pois o mediador no processo de mediação tenta buscar soluções que as partes em conflito possam aceitar e consigam a partir disto reconstruir as suas relações e conseguir transformar o conflito em disputas políticas. E para conseguir realizar a mediação 
é fundamental que as partes cooperem com o mediador e entre si. (ver MELLO, 1997, pp. 1344-1346)

\subsection{O conflito}

As principais etnias presentes no Burundi são os Hutus (85\%), Tutsi (14\%) e Twa (1\%). Embora a percepção de que a divisão étnica seja um dos principais motivadores do conflito, devido a décadas de manipulação sócio-étnicas identidades, também existem clãs importantes, divisões regionais e divisões baseadas nas classes sociais. (MAKOBA; NDURA, 2006, p. 295) As divisões étnicas não são resultado de ódios pré-coloniais entre Tutsis e Hutus, na realidade eles prometiam fidelidade ao mesmo rei. As tensões da Guerra Fria exacerbaram os confrontos entre os grupos sociais, principalmente entre os "privilegiados Tutsis" e os "servos Hutus", além das facções políticas que lutavam pela independência e as que eram leais as ex-potências coloniais.

O vencedor das primeiras eleições democráticas em 1961 e líder do UPRONA (União pelo Progresso Nacional), partido anti-ocidental, foi assassinado supostamente em nome do Príncipe Jean Ntitendereza, pró-ocidental. Durante a luta, que se seguiu pela dominação dentro do UPRONO a clivagem Hutus e Tutsis, emergiu como padrão dominante de conflito e linha de lealdade. Esta divisão étnica produziu um clima generalizado de desconfiança que foi aprofundado a cada crime contra a humanidade e genocídio. (NIJIMBERE, 2004, p. 1) A lealdade fragmentada que pode ser percebida claramente na sociedade burundiana é uma das características dos Estados falidos. (ver MÜNKLER, 2004, p. 8)

As causas do conflito no Burundi passam tanto por questões étnicas, como por problemas relacionados a disputa política e econômica. As principais causas do conflito são: a falta de concorrência, as clivagens étnicas e suas manipulações, e os desequilíbrios regionais. (BRACHET; WOLPE, 2005, pp. 4-5) No entanto, as causas étnicas foram usadas para encobrir as verdadeiras causas do conflito e os interesses e reivindicações pessoais ou de elites no poder. Sendo assim, as intervenções trataram o conflito como étnico, sendo que este não era a única causa deste. (NIJIMBERE, 2004, p. 1) A mediação precisa tratar das reais causas do conflito, principalmente quando envolve conflitos complexos, caso isto não ocorra 
a mediação está fadada ao fracasso. (ver DEBRIX, 1999, p. 196) Como apresentado no primeiro capítulo, mesmo que as clivagens da sociedade e as questões étnicas não sejam a motivação do conflito, as elites utilizam-se desses fatores para conseguir apoio da população e legitimar as suas ações contra o “outro”. (ver MÜNKLER, 2004, p. 6)

As divisões presentes na sociedade burundiana foram exacerbadas por diferentes oportunidades sociais, uma história de violência e impunidade contra a população e as minorias, desempenho pobre da economia; a desigualdade e o estresse ambiental, falha de governança e nas instituições e as repercussões dos efeitos dos conflitos regionais. (p. 2) A rivalidade entre as etnias era utilizada como justificativa para golpes, assassinatos e revoltas. Os recursos étnicos tornaram-se poderosos para legitimar e mobilizar as massas. Complicando ainda mais o mosaico de divisões contemporâneas. (p. 5) $\mathrm{O}$ ataque ao outro e o medo deste são legitimadores para o ataque a ele e, por isso, são utilizados pelas elites e grupos armados para justificar os seus ataques. (ver MÜNKLER, 2004, pp. 6-7)

Percebe-se que diversas características dos conflitos complexos no conflito do Burundi. Primeiramente, o conflito do Burundi tem forte influência regional, pois o conflito no Burundi é influenciado e influencia outros conflitos na região dos Grandes Lagos, por exemplo, os de Ruanda, Uganda e República Democrática do Congo. Sendo que não é possível separar a história do Burundi da de Ruanda, as semelhanças entre os dois genocídios devem ser consideradas, a grande diferença é que, no genocídio burundiense, os Hutus eram os alvos. (LEMARCHND, 2009, p. 408) O regionalismo vem sendo estudado como um dos possíveis causadores de conflito. No Burundi, isto fica evidente, a sua localização em uma das áreas mais instáveis do mundo e dos grandes catalisadores para o conflito. (ver MIALL; RAMSBOTHAM; WOODHOUSE, 2009, pp. 98-99)

Em segundo lugar, o Estado burundiense é falido, com independência recente e falta de preparo na sua independência, tal como a construção de instituições fortes, o que resultou nas instituições fracas, as quais não conseguem suprir as necessidades básicas da população. Fazendo com que a legitimidade do Estado seja enfraquecida ou perdida e as clivagens sociais fortaleçam-se. Como colocado anteriormente, as lealdades já eram fragmentadas desde a sua independência, devido às questões étnicas, sendo assim, a fragmentação e o fracasso do Estado são consequências dessa fragmentação étnica. Mas, a situação do Estado agravou 
as clivagens e não conseguiu construir um Estado realmente. (ver CARMENT, 2003; RAMSBOTHAM: WOODHOUSE; MIALL, 2009, p. 100-101)

Em terceiro lugar, a globalização impõe ao Estado a entrada no comércio internacional, o que faz com que os burundineses não consigam controlar o seu desenvolvimento. (ver MÜNKLER, 2004, p. 8) Em quarto lugar, o Estado adota políticas de exclusão que exacerbam as clivagens sociais, que já estão extremamente presentes na sociedade. (ver RAMSBOTHAM; WOODHOUSE; MIALL, 2009, p. 87)

O conflito do Burundi pode ser divido em dois momentos, o primeiro iniciando em 1972 e o segundo em 1988; no entanto, em ambos os casos as raízes dos conflitos armados são anteriores à eclosão do conflito. Além disso, como colocado no primeiro capítulo, é muito difícil determinar o momento de início, interrupção, término e recomeço do conflito devido a sua fluidez. É provável que não se tenha dois conflitos no Burundi, mas o segundo é a continuidade do primeiro. (ver MÜNKLER, 2004, p. 13)

O conflito iniciado em 1972 com a revolta Hutu e o genocídio posterior que matou aproximadamente duzentas mil pessoas, em sua maioria Hutus. As tensões entre Tutsis e Hutus iniciaram fortemente em 1965, após as primeiras eleições pós-independência para a Assembléia Nacional. Pois, embora a vitória dos Hutus nas urnas, o Primeiro-Ministro nomeado não foi Hutu. Em 18 de outubro de 1965, os Hutus tentaram dar um golpe fracassado no palácio real, seguido por ataques esporádicos contra elementos Tutsis no campo. Em pânico, o Rei fugiu do país e nunca mais voltou. Os poucos políticos Hutus que sobreviveram às represálias viam como única saída para as reivindicações Hutus a luta armada. (p. 409) Como colocado no primeiro capítulo, quando as políticas de exclusão são tão fortes, o Estado não possui instituições para tratar dos conflitos internos e da parcela da população que não está representada no poder, os grupos insatisfeitos veem a luta armada como única solução possível para as suas reivindicações. (ver CARMENT, 2003, pp. 414-415)

A polarização dos sentimentos étnicos, logo após a independência, deve ser analisada em relação ao enorme poder de atração do modelo de Ruanda perante os líderes Hutus que viram na ideologia republicana de seu vizinho a promessa de um futuro melhor. A exclusão sistemática dos Hutus em todas as posições de responsabilidade no governo, do serviço civil e dos cargos mais elevados das 
forças armadas é central para entender a rebelião Hutu de 1972. No entanto, chama a atenção as tensões entre os Tutsis, a crescente divisão no seio da oligarquia dominante é o que levou os rebeldes a explorá-la. (p. 409)

Em abril de 1972, o conflito começou quando Micombero, o qual tomou o poder em 1966 depois de um golpe sobre a monarquia burundiana, negou os provimentos de seu gabinete, com o objetivo de fortalecer o seu poder político. $\mathrm{Na}$ mesma noite, uma revolta de Hutus eclodiu em Bujumbura e nos distritos de Rumonge, Nyanza e Bururi. Um número não preciso de Hutus participou da revolta contra os Tutsis indiscriminadamente nas províncias do sul e contra os Hutus que se recusaram a participar da revolta, em Bururi, onde, na rebelião, todas as autoridades militares e civis foram mortas. Uma semana após o início da revolta rebelde, tropas do governo foram enviadas para as regiões. (pp. 410-411) Pode-se perceber outra característica dos conflitos complexos, pois os ataques foram direcionados tanto aos Tutsis civis, em um claro direcionamento étnico e aos Hutus que se recusaram a participar, pois o medo tem que estar presente nos dois grupos e o recrutamento é feito dentro da sociedade. Outro ponto é que os ataques foram direcionados principalmente à população civil, alastrando o ódio ao “outro”. (ver BUTTLER, 2009, p. 60)

A represália contra os revoltosos foi extremamente violenta levando ao massacre de Hutus. Em outras partes, um padrão foi claramente estabelecido. Os ataques eram direcionados aos Hutus que possuíam dinheiro, educação e/ou emprego público. As vítimas da represália eram, em sua maioria, Hutus; mas, não exclusivamente. Existem evidências de que a represália foi utilizada como oportunidade para a resolução de antigos conflitos intra-Tutis. Em 30 de abril, após determinar a lei marcial o Presidente Micombero solicitou ajuda militar ao Zaire (atual República Democrática do Congo), a qual foi responsável por assegurar o aeroporto. (pp. 411-413)

Apesar da represália ter iniciado por parte do exército em resposta à rebelião Hutu, o que se seguiu foi muito mais amplo. Até agosto de 1972, aproximadamente de cem a cento e cinqüenta mil Hutus foram mortos, sendo que esse massacre matança não foi realizado somente pelo governo, mas por toda a população Tutsi, que formaram grupos paramilitares com o auxilio dos jovens da UPRONA, os quais se denominavam como Jeunesses Révolutionnaires Rwagasore (JRR). A população aderiu ao genocídio de Hutus fortemente, 
incentivados por inimizades pessoais e a possibilidade de apropriar-se das propriedades das vítimas. Todavia, não se pode considerar que todos os Tutsis apoiaram o genocídio, contrariamente, Tutsis iam até o governo central solicitando o fim do genocídio, pois o massacre já estava muito escalonado, criaram abrigos para os Hutus e os protegeram; porém, esse grupo de Tutsis também era morto pelo governo. (pp. 410-415) A utilização da coerção massivamente por parte do governo contra população é um dos indicadores de um Estado falido, usurpado por uma pequena elite, a qual não possui legitimidade perante a população e precisa utiliza-se da coerção para conseguir manter o poder. (ver CARMENT, 2003, p. 413).

O medo do "outro" estava presente nos Hutus e nos Tutsis. Muitos Tutsis viram o massacre como a única maneira de assegurar de que eles não sofreriam novamente com ataques por parte dos Hutus. Enquanto os Hutus entendiam que a única maneira de ter as suas reivindicações atendidas era pela luta armada voltada para a população civil e lutando pelo poder político. O resultado desse ódio e medo ao "outro" juntamente com a brutal violência é gerações de manutenção das tensões entre Tutsis e Hutus. (p. 414) Percebe-se, então, que o genocídio no Burundi contém diversas características do conflito complexo, apesar deste conflito estar acontecendo antes do fim da Guerra Fria. O ódio pelo "outro", a falta de diálogo, de instituições competentes, o medo amplamente disseminado pela população, a diversidade de forças atuando no conflito, o Estado fraco e perpetuador de violência contra a população são sinais claros dos conflitos complexos. (ver o tópico 2.1.2.)

O massacre teve impacto devastador sobre a sociedade do Burundi, reconfigurando drasticamente o mapa étnico, visto que em agosto todos os Hutus educados e ricos estavam mortos ou refugiados junto com grande parte da população Hutu, e estabeleceu separação profunda entre Hutus e Tutsis. O massacre Hutu permitiu o surgimento de uma etnocracia Tutsi, protegida por um exército completamente Tutsi, o qual divulgou que os Hutus tinham impetrado o massacre no Burundi que foi somente contido pelo governo Tutsi, de maioria Hima. (LEDERMACH, 2009, p. 407) A comunidade internacional silenciou-se sobre o ocorrido e mostrou-se esperançosa de que o governo Tutsi conseguia estabelecer a paz no Burundi. (pp. 415-416) 
Em 1976, Jean Bagaza realizou um golpe militar no governo de Micombero e assume o poder, estabelecendo a Segunda República. Inicialmente, Bagaza aparentou tentar uma reconciliação entre os grupos Tutsis rivais e os Hutus. (ELECTORAL INSTITUTE FOR THE SUSTENTABILITY OF DEMOCRACY IN AFRICA) Corroborando esta ideia a nova Constituição foi aprovada pela população e promulgada em 21 de novembro de 1981. No entanto, a UPRONA continuava como único partido e manteve-se o poder concentrado nos Tutsis, isolando a participação dos Hutus na vida pública.

O governo de dominância Tutsi governou por aproximadamente 20 anos e os 16 anos após o massacre foi o maior período pacífico do Burundi. O país estava praticamente desprovido de elite Hutus instruída, que era a ameaça presente anteriormente, o massacre foi suficiente para desencorajar todas as formas de protestos, e o exército era formado somente por Tutsi, protegendo assim o governo. A impressão superficial de paz foi repentinamente quebrada em agosto de 1988, com a explosão dos conflitos étnicos nos municípios de Ntega e Maragara, localizados no norte do país. (LEDERMACH, 2009, 417)

O massacre de 1988 foi desencadeado pelas provocações de um país com políticas claramente favoráveis aos Tutsi e alimentada por rumores de um iminente massacre de camponeses Hutus, a turbulência resultou na morte de centenas de vidas civis Tutsis antes de o exército ir para a região e desencadear outra repressão sangrenta. Enquanto cerca de quarenta mil Hutus em pânico refugiaram-se em Ruanda, segundo relatos da imprensa, e vinte a trinta mil foram mortos pelo exército. (p. 417)

Em contraposição ao que aconteceu em 1972, a comunidade internacional reagiu aos assassinatos com choque. A cobertura substancial da imprensa dos eventos, juntamente com acusações de graves violações aos direitos humanos pela Comunidade Européia foram fundamentais para convencer o governo de Burundi a introduzir importantes reformas constitucionais e políticas. Ainda mais decisivo para reforçar as recentes reformas pelo governo burundiano foi a audiência do Congresso dos Estados Unidos da América, realizada em setembro de 1988, seguida pela aprovação de uma resolução não vinculante pedindo ao governo do Burundi a conduzir uma investigação imparcial sobre as circunstâncias da turbulência, tomando medidas para investigar e processar os responsáveis pelas atrocidades cometidas durante e após a turbulência, e o mais importante 
possibilitando, assim, o retorno seguro as suas casas da população refugiada.(p. 417)

Percebe-se uma diferença considerável na postura internacional perante os dois massacres no Burundi. A diferença de atitude por parte da comunidade internacional pode ter várias explicações; no entanto, é necessário incluir o poder da mídia internacional que noticiava o acontecimento e que fazia a opinião pública internacional cobrar medidas dos seus respectivos governos, e o praticamente fim da Guerra Fria, a qual suprimia os demais conflitos internacionais, o que fazia com que as atenções internacional voltasse para os demais conflitos e, principalmente, os conflitos étnicos presentes na comunidade internacional. (ver MIALL; RAMSBOTHAM; WOODHOUSE, 2009, p. 83)

As autoridades do Burundi compreendiam que ignorar as advertências do Congresso norte-americano implicaria grandes custos em termo de assistência econômica e empréstimos internacionais. (pp. 417-418) Os Estados Unidos da América estavam utilizando-se do seu poder de recompensa para fazer com que as autoridades burundineses mudassem as suas posições. Apesar de não estar realizando uma mediação e não prometer nenhum novo ganho ao Burundi, os Estados Unidos da América estavam avisando que caso a postura burundiense não modifica-se os benefícios recebidos por eles seriam cortados. (ver AALL, 2007, pp. 485-486)

Em decorrência, o governo colocou em tramite reformas que culminaram com promulgação da Constituição, em 1992, e na organização das eleições presidenciais e legislativas multipartidárias, em 1993. Durante este período, intelectuais Hutus fundaram a Frente para a Democracia no Burundi (FRODEBU), a qual tornou-se rapidamente o maior partido de oposição. Outros partidos foram criados neste período ligados aos Hutus e aos Tutsis. (MINISTÉRIO DAS RELAÇÔES EXTERIORES DO BRASIL) A eleição foi marcada pela predominante vitória dos Hutus com a Frente Democrática do Burundi (FROBEBU) e a eleição do seu candidato para a presidência, Melchior Ndadaye. Retirando, assim, a minoria Tutsi do poder, definitivamente. (LEDERMACH, 2009, p. 418) "An important feature of the political system in Burundi is the high degree of ethnicization of politics." (NDKUMANA, 1999, p. 
Ndadaye iniciou uma política de ação afirmativa, a qual objetivava aumentar a participação Hutu na vida política do país. A medida desagradou os Tutsis, que alegaram o despreparo por parte dos Hutus para governar. Enquanto, extremistas Hutus defendiam um governo dominado por Hutus. Resultando, na morte de Ndadaye e proeminentes líderes do FRODEBEU por militares Tutsis, em 21 de outubro de 1993, após 100 dias de governo. A ação foi feita por extremistas Tutsis que viram na chegada ao poder de um líder Hutu a ameaça a sua sobrevivência, e o fim dos seus privilégios políticos e econômicos. O mesmo grupo de extremistas Tutsis deu um golpe de estado. Em reação, grupos extremistas Hutus iniciaram o massacre discriminado de Tutsis, o que provocou intervenção militar e diversas mortes. (MINISTÉRIO DAS RELAÇÕES EXTERIORES DO BRASIL)

Após décadas de benefícios e controle irrestrito das instituições do Estado, uma transferência de poder para os Hutus tinha implicações nefastas para os Tutsis. O retorno do status quo por meio do assassinato político parecia o mais viável dado o perfil do exército. O que não foi previsto por eles foi a resposta violenta da comunidade Hutu. A notícia da morte de Ndadaye foi recebida pelos Hutus com uma violenta reação anti-Tutsi. Resultando na morte de aproximadamente vinte e cinco mil Tutsis pelos seus vizinhos Hutus, provocando a reação do exército em retaliação, o qual assassinou milhares de Hutus. Apesar de o único genocídio atualmente reconhecido por Burundi ser o de Tutsis em 1993, a memória do genocídio de 1972 é necessária para explicar a resposta violenta dos Hutus. (LEDERMACH, 2009, pp. 418-419)

Após o assassinato de Ndadaye, em 1993, foram iniciadas reuniões secretas que falharam após o ex-presidente Pierre Buyoya derrubar o governo, por meio de um golpe militar, em 25 de julho de 1996. (NIJIMBERE, 2004, p. 2) O golpe foi impelido contra o presidente Cyprien Nataymira, que morreu em um acidente de avião em 1994. Posteriormente a este evento, a FRODEBEU resolveu assinar um acordo de repartição de poder com a UPRONA, o qual foi considerado uma traição por extremistas Hutus, resultando na criação do Conselho Nacional para Defesa da Democracia (CNDD) e o seu braço armado, a Força para a Defesa da Democracia (FDD) por eles, que passou a combater diretamente o exército regular. O governo tentou realizar uma reconciliação, mas esta foi rejeitada pelo Partido para a Reconstrução Nacional (PAREMA), do ex-presidente Bagaza, que 
era contrário à repartição do poder. (MINISTÉRIO DAS RELAÇÕES EXTERIORES DO BRASIL)

Neste momento o Burundi já se encontrava em guerra civil, contendo milhares de milícias combatendo as forças do exército regular e lançando ataques contra a população civil. Diante desta situação, o Presidente Ntibantunganya solicitou aos ex-Presidente da Tanzânia e então mediador designado para a região dos Grandes Lagos, Julius Nyerere, e que era apoiado pela ONU e a Organização da Unidade Africana, um parecer sobre a situação do Burundi. Nyerere mostrouse favorável à intervenção de uma força regional na região. Características apresentadas no primeiro capítulo como sendo dos conflitos complexos mostramse claramente no conflito do Burundi. Primeiramente, a diversidade de forças presentes no conflito, o qual contava com dezenas de milícias Tutsis e Hutus lutando contra o exército regular. (ver BUTLER, 2009, pp. 58-60) Em segundo lugar, a utilização de armamento leve ou precário pelas forças durante o conflito, existem relatos que os confrontos anteriores foram realizados por meio de armas brancas e armas leves. (LEDERMACH, 2009, p. 414) (ver MÜNKLER, 2004, p. 15) Em terceiro lugar, a violência direcionada aos civis por parte das milícias e pelo exército. (ver BUTLER, 2009, p. 60) Em quarto lugar, a fragilidade do Estado que não conseguia manter nem mesmo as instituições básicas funcionando. Em quinto e último lugar, a busca pelo conflito armado como único modo de resolver os seus conflitos por parte dos grupos, os quais não acreditavam na resolução por meios políticos. (ver CARMENT, 2003)

A violência escalonou devido à proibição de Buyoya de qualquer atividade política, $\mathrm{O}$ exército não conseguindo mais conter os ataques rebeldes colocou a população em “zonas seguras”, locais os quais eles poderiam manter a segurança; contudo, os locais também eram insalubres, causando sérios problemas de natureza humanitária. Um dos $80 \%$ das mortes nos conflitos complexos são provenientes das consequências em termos materiais da guerra, a destruição da estrutura física do Estado faz com que a população sofra indiretamente com o conflito e acabe morrendo devido a doenças simples, fome ou outros motivos básicos. (ver MÜNKLER, 2004, p. 14)

A população burundiana sofre ainda com a exclusão e a desigualdade em um contexto de extrema pobreza e escassez de recursos. A exclusão dos Hutus de toda a vida política, econômica e social do Burundi, uma prática que se iniciou em 
1965 e atingiu o seu ápice com o massacre em 1972 do segmento de Hutus educados. A exclusão dos Hutus não teve somente motivação étnica, mas também econômica e de concentração das terras nas mãos dos poucos Tutsis. Pois, não foram somente as clivagens sociais e étnicas que levaram ao conflito violento, mas também, o contexto de aprofundamento da depressão econômica, a concentração de riquezas e do poder político na mão de uma pequena elite urbana e conflitos relacionados ao acesso à terra, ampliando disparidades sociais ao longo do tempo. (BRACHET; WOLPE 2005, p. 5)

O capital social do Burundi se enfraqueceu durante os anos de conflito violento. A desconfiança e o medo cresceram ente os Hutus e Tutsis, aprofundou a divisão entre regiões, entre as "classes políticas" e a população e a polarização das instituições minou seriamente a capacidade tradicional do Burundi de resolver os seus conflitos sem violência. Em contrapartida, a ligação intergrupos se fortaleceu, no entanto, não se manifestaram de modo positivo, e também não conseguiram acabar com as divisões internas. (p. 6)

A economia do Burundi, o crescimento populacional rápido, e a concentração da economia e do poder político nas mãos de um pequeno sub-grupo da minoria Tutsi, não só limitaram as aspirações sócio-econômicas para parte dos Tutsis e Hutus, mas também para fazer as etnias e clivagens regionais mais agudas. Todavia, não são todas as regiões não são afetadas da mesma forma pela violência étnica e polarização e, consequentemente, as dinâmicas políticas locais variam. (p. 8)

\subsection{Resolução}

No período de 1994 a 1996, a ONU tentou facilitar a negociação de novos acordos de partilha de poder para o Burundi com o objetivo de estabilizar a onda de violência de 1993. Esta tentativa foi prejudicada pela ausência de um ator internacional disposto a assumir a liderança diplomática ou o apelo do Secretário Geral da ONU. (BRACHET; WOLPE, 2005, p. 2)

A comunidade internacional não pôde tolerar o golpe militar de 1996 e estabeleceu uma Assembléia ad hoc de Chanceleres na cidade de Arusha, na Tanzânia, que foi denominada como "Iniciativa Regional", com a mediação de Julius Nyerere. Participaram da reunião representantes do Quênia, Ruanda, Zaire 
(atual República Democrática do Congo), Etiópia, Estados Unidos da América, União Européia (UE) e o Secretário da Organização da Unidade Africana (OUA). Desta reunião, ficou decidida a imposição de embargo econômico ao Burundi, o que é extremamente prejudicial ao país devido a não possuir saída para o mar, o qual foi endossado pela ONU e pelos países doadores de ajuda financeira. Eles possuíam o objetivo de forçar Buyoya a restabelecer a ordem constitucional. (MINISTÉRIO DAS RELAÇÕES EXTERIORES DO BRASIL) Aqui, os Estados endossados pela ONU e pela OUA estavam utilizando o seu poder de barganha para levar o conflito para a mediação. (ver AALL, 486; LANZ; SGUAITAMATTI, pp. 9-10)

Pressionado, Buyoya aceitou participar discretamente das negociações conduzidas pelo Padre Matteo Zuppi da Comunidade Sant 'Egidio (ver tópico 4.1) em novembro de 1996. O Padre Zuppi também enviou uma delegação ao principal grupo armado de oposição, o CNDD-FDD. Os enviados belgas e norteamericanos participaram da equipe de mediação. Ambas as delegações concordaram sobre a agenda para novas negociações, denominada "Agenda de Roma”. (NIJIMBERE, 2004, p. 2) As reuniões foram secretas, com o envolvimento discreto das partes, este tipo de reunião é uma das vantagens das ONGs na mediação internacional, apesar de que neste caso também inclui a participação de indivíduos importantes e de Estados. (ver EVANS-KENT; BLEIKER, 2003, pp. 107-109)

Buyoya relatou esses progressos na mediação aos chefes de Estado da "Iniciativa Regional" na tentativa de convencê-los a encerrar o embargo. No entanto, quando Nyagoma tomou conhecimento da atitude de Buyoya fez com que os esforços convertem-se em uma negociação pública em abril de 1997. Como resultado, a comunidade Tutsi acusou o chefe da delegação do governo de traição. (p. 2) Ao transformar a negociação em pública o Nyagoma está utilizando do seu poder de mediador para determinar o local e o acesso da mídia na mediação. Quando foi decidido que as reuniões seriam fechadas e longe da mídia e a agenda das negociações também estavam se utilizando do poder do mediador de decidir onde vai ser a mediação e quais os tópicos que estarão na agenda, obviamente, que isto é realizado em conjunto com as partes. (ver CHIGAS, 2007, pp. 559-560)

Como a solução para o conflito não foi alcançada com a negociação para a divisão do poder entre os dois grupos étnicos, os chefes de Estado da região 
solicitaram a inclusão de Julius Nyerere na mediação, ameaçando manter o embargo se isto não acontecesse. Essa nova rodada de medição deveria acontecer em agosto de 1997 em Arusha; no entanto, o governo burundiano resistiu a tais ordens e sugeriu uma pré-negociação no seio da sociedade do Burundi. Buyoya ainda tentou atrasar as negociações impondo condições prévias. A comunidade internacional, contudo, ficou totalmente impressionada com as demandas e a Iniciativa Regional respondeu a cada uma dessas solicitações endurecendo ainda mais o embarco. Eventualmente as negociações sem pré-condições iniciaram-se em junho de 1998, Julius e, posteriormente, Nelson Mandela mediaram as negociações que em agosto de 2000 levaram à Paz de Arucha e ao "Acordo de Reconciliação". (NIJIMBERE, 2004, p. 2)

Julius Nyerere, ex-Presidente da Tanzânia, tornou-se o mediador de um processo de paz patrocinado regionalmente. O processo de paz se dividiu em três pilares interligados: Arusha, Roma e Bujumbura. Contudo, Nyerere foi enfraquecido pela confiança limitada do mediador nas negociações das partes, devido à multiplicidade de patrocinadores regionais no processo de Arusha e tensões com outros mediadores e com o interlocutor Tuti, o Presidente Buyoya. Além disso, os Tutsis consideravam Nyerere tendencioso para os Hutus, por ele também ser o impulsionador do regime de sanção imposta pelos países regionais. Devido a estes acontecimentos e fatos, a neutralidade e credibilidade do processo de Arusha foram se esvaziando. No entanto, apesar de todas as pressões sofridas, Nyerere e sua equipe conseguiram levar os líderes burundianos ao acordo, mas somente a alguns protocolos, os quais acabariam por ajuda a encontrar o caminho para o Acordo final de Arusha. (BRACHET; WOLPE, 2009, p.2) A relação de confiança entre as partes e os mediadores é fundamental (KLEIBOER, 1996, p. 369); bem como a percepção das partes em relação ao mediador, o qual pode estar ligado à imparcialidade (ver KLEIBOER, 1996, p. 381) e à coordenação entre os mediadores (ver CHIGAS, 2007, p. 571). É impossível realizar uma mediação onde esses elementos não estão presentes.

Observa-se a importância da percepção das partes em relação ao mediador (ver RICHMOND, 1998,p. 721), do histórico do mediador e do seu relacionamento com as partes (ver BERCOVITCH; HOUSTON, 1996, p. 20), pois os Tutsis não consideravam imparcial na mediação devido a ações anteriores tomadas por ele quanto representante da Tanzânia na Conferência Regional de 
Chanceler. O importante não era a se as atitudes do mediador eram imparciais durante a mediação, mesmo que neste caso ela não fosse, mas a percepção da parte, no caso dos Tutsis, frente o mediador, a qual foi fortemente influenciada pelo histórico do mediador e o seu relacionamento com ele. A percepção desfavorável por parte dos Tutsis fez com que Nyerere perdesse a sua credibilidade e a mediação foi esvaziada. Outro ponto importante é a falta de coordenação entre os patrocinadores, o que acabou por prejudicar a mediação, pois é fundamental que tanto os mediadores como os patrocinadores tenham atitudes coordenadas ou então a mediação perde-se entre opiniões e medidas divergentes. (ver KLEIBOER, 1996, p. 369)

Ao mesmo tempo em que era realizada, as negociações de Arusha, conversações secretas tiveram lugar entre o governo e o CNDD-FDD, liderado por Jean Ndayikengurukiye, mediada por Jan Van Eck, que trabalhava para o Center for Conflict Resolution. Esta facção ainda não tinha sido incluída nas negociações oficiais de Arusha. No entanto, as negociações chegaram abruptamente ao fim quando iniciou a segunda guerra na República Democrática do Congo contra o presidente Kabila. Pois, Ndayikengurukiye foi convidado por Kabinda para ajudar as suas tropas e, consequentemente, rompeu unilateralmente as negociações. (NIJIMBERE, 2004, p. 2)

As reuniões secretas entre o governo e o CNDD-FDD tinham que ser realizadas por uma ONG por dois motivos. O primeiro é que ele era um grupo armado ilegítimo, que desrespeitava os direitos humanos e não era reconhecido nacionalmente e internacionalmente. (ver CHIGAS, 2007, p. 561) Ao contrário dos Estados e organizações internacionais que teriam um alto custo político para envolver-se em negociações e mediações com grupos considerados ilegítimos. (ver MITCHELL,1992, p. 277). Era necessário, ainda, que as reuniões fossem realizadas em segredo para não expor o envolvimento entre o governo e o CNDDFDD e para que eles pudessem negociar de forma mais criativa e aberta, sem a interferência de grupos, dentro ou fora deles, que não desejassem a mediação. (ver CHIGAS, 2007, p.559-560; RICHMOND, 1998, pp. 710-713)

Em complementação a sua mediação secreta entre o governo e o CNDDFDD, o CCR em conjunto com o Search for Common Ground desenvolveram o "Projeto de diálogo Político" entre os anos de 1995 e 2001. O projeto era implementado juntamente com a mediação no Burundi realizando oficinas entre 
as partes. O objetivo das oficinas era criar e/ou incentivar as partes no processo de confiança e empatia, ou seja, fazer com que as partes se enxergassem no lugar do outro, tentando assim entender o posicionamento do outro e desenvolver o relacionamento sustentável. Baseado na filosofia defendida pelo Search for Common Ground, as oficinas tentavam restabelecer o relacionamento entre as partes, o qual estava extremamente desgastado. (ODENDAAL; HONWANA, 2005) As ONGs possuem como uma das suas vantagens poder realizar oficinas discretas, nas quais as partes podem testar as suas ideias, quebrar percepções erradas ou construídas numa relação anterior de ódio e preconceito, e desenvolver relações de confiança. (ver CHIGAS, 2007, pp. 559-560)

O protagonista deste processo foi Jan Van Eck, então consultor sênior do CCR. Van Eck passava a maior parte do seu tempo no Burundi, enquanto um pequeno grupo de consultores do CCR fazia reuniões periódicas com ele durante as suas visitas a Cidade do Cabo, analisando os desenvolvimentos recentes, selecionando opções e identificando oportunidades de ações complementares, tais como treinamento e formação em resolução de conflito, técnicas de negociação e capacitação de órgãos da sociedade civil. A análise constante e a adaptação aos acontecimentos é uma das necessidades impostas pelos conflitos complexos.

Van Eck revelou-se hábil moderador num exercício extremamente delicado. Ele era especializado na capacidade de construir negociadores, apoiando as partes para chegarem ao mesmo nível de conhecimento e competência necessários para as negociações. O objetivo dos seminários de capacitação organizados pelo CCR era retirar o medo envolvido no relacionamento das partes e garantir negociações equilibradas, durante a qual nenhum partido teria a sensação de que havia perdido e sim que todos tinham ganhado. (NIJIMBERE, 2004, p. 3) As oficinas realizadas pelo CCR e os seus objetivos podem ser classificados como uma mediação de segunda via, ou seja, como complementar a mediação realizada pelo mediador principal. Em contrapartida, a mediação realizada por ele entre o governo e o CNDD-FDD pode classificar-se como uma mediação de via um e meio apesar de não estar inserida na mediação principal, pois o CRR estava sendo o mediador principal entre esses dois grupos. (CHIGAS, 2007, pp. 555-556) O objetivo das oficinas era acabar ou pelo menos diminuir a assimetria entre as duas partes, o que é fundamental para a mediação. (ver JONES, 1999, p. 59) 
Nos seus incontáveis encontros com um amplo número de representantes dos diversos grupos políticos do país, Van Eck procurou e conseguiu em grande medida compreender o conflito na perspectiva dos diferentes protagonistas. (ODENDAAL; HONWARA, 2005) Nas palavras dos próprios burundineses:

"Nós vimos muitos outros que vinham com as suas ideias, não nos ouviam e nem nos procuravam entender. Van Eck ouviu-nos com imensa paciência, mesmo quando nós repetíamos a mesma história várias vezes. Ele não nos impôs as suas ideias. A princípio ele nem oferecia sugestões, só fazia perguntas.” (SEARCH FOR COMMON GROUND, 1999)

Observa-s que a mediação de via um e meio realizado pelo CC,R no caso do CNDD-FDD, e de segunda via, realizada pelo CCR e Search for Common Ground, têm diversas qualidades como a flexibilidade, a preocupação em resolver os problemas causais do conflito, o profundo estudo do conflito e a adaptação aos novos acontecimentos. Em contrapartida, Van Eck não se envolveu profundamente na sociedade burundiense, o envolvimento dele foi mais centrado nos líderes, o que é extremamente preocupante em conflitos complexo, especialmente no caso do Burundi que possuía clivagens sociais e ódio ao "outro" tão enraizados na sociedade. Sendo assim, Van Eck perdeu uma das principais vantagens da mediação realizada por ONGs que é a capacidade de realizar a mediação no modelo piramidal, o qual envolve toda a sociedade. (ver ZARTMAN; TOUVAL, p. 445) Esse erro não foi cometido somente pelo CCR e o Search for Common Group, mas a Comunidade Sant'Egidio que estava dentro da mediação principal no pilar de Roma também não teve a capacidade de realizar a mediação no modelo piramidal, principalmente porque não estava tão inserida na sociedade burundiana como deveria para ter redes de relacionamento sólidas. (ver CHIGAS, 2007, p. 562; NATSIOS, 2007, pp.343-344)

Em 1999, as sanções foram suspensas, o que foi motivo de reclamação por parte dos grupos rebeldes, que acreditavam que a suspensão poderia desestimular o governo a prosseguir o diálogo político com a oposição. (MINISTÉRIO DAS RELAÇÕES EXTERIORES DO BRASIL) Atitude a qual quando analisada destaca a vontade dos rebeldes de saírem do conflito, podendo ser a indicação da maturação do conflito. No entanto, é necessário ponderar se as forças entre o 
governo e os rebeldes estavam equilibradas após a retirada das sanções, sendo imperativo a reavaliação das disposições de força no conflito.

Com a morte de Nyerere, em outubro de 1999, Nelson Mandela foi convidado para ser o mediador, em fevereiro de 2000, o que deu uma nova atmosfera ao processo de mediação. Mandela apresentou um plano de mediação baseado em três pontos principais: a instituição da Comissão de Verdade e Reconciliação; um balanceamento étnico da composição das forças armadas; e a libertação de presos políticos. O objetivo declarado no projeto era transformar o Burundi em uma democracia multiétnica e pluripartidária. (BRACHET; WOLPE, 2005, p. 2)

O Acordo de Arusha foi assinado pelas 19 partes participantes da mediação em agosto de 2000. O Acordo é composto por cinco protocolos, sendo que cada um trata de temas específicos: boa governança, segurança, reconstrução econômica e como assegurar a implementação do Acordo. Dois pontos são apontados como fundamentais para a resolução do conflito no Acordo: a distribuição igualitária dos recursos e a necessidade de ajuda internacional. (ACORDO DE PAZ E RECONCILIAÇÂO DE ARUSHA PARA O BURUNDI, 2000) O Acordo serviu de modelo para a divisão de poder e a reforma das instituições chaves, prescritas nele que deveriam acontecer no período de transição de 36 meses, o qual começaria em 01 de novembro de 2001. (BRACHET; WOLPE, 2005, p, 2)

Apesar dos seus avanços, três questões básicas impediram a implementação bem-sucedida do Acordo: a falta de apoio dos dois principais grupos armados, a não determinação no Acordo de quem lideraria a transição e como seria a reforma no setor de segurança. (p. 2) A mediação precisa envolver todos os atores importantes do conflito, a falta de dois dos principais grupos armados do conflito é um forte sinal de impossibilidade de implementar o Acordo e de vai ser imperativo uma segunda rodada de mediação.

No processo pós-Arusha, que por muitas vezes se assemelhou a uma arbitragem, Mandela e os patrocinadores regionais persuadiram os líderes burundineses a fazer a transição de forma dividida em duas partes iguais, com os primeiro 18 meses sendo governando por Buyoya e os demais 18 meses pelo seu vice-presidente Hutu Domitien Ndayizeye. (p. 2) A mediação não é uma arbitragem por diversos motivos, o principal é que a mediação subentende o 
envolvimento das partes em todo o processo de negociação, sendo função da terceira parte somente coordenar, auxiliar o processo feito pelas partes e sugerir alternativas pacificas para solucionar o conflito. Isto é programado para que as partes tenham um alto nível de engajamento com as decisões acordadas no Acordo de Paz. Em decorrência disso, empenham-se na implementação dessas decisões junto aos seus grupos e com toda a sociedade, trabalhando conjuntamente para conseguirem implementar todo o Acordo de Paz. (ver MELLO, 1997, pp. 1344-1346)

Durante todo o processo de mediação, o CCR e o Search for Common Ground continuaram o seu projeto de oficinas para o Burundi; no entanto, com a retirada de Van Eck do CCR, em 2001, o projeto foi interrompido. Van Eck continuou a apoiar a resolução do conflito no Burundi, mas não mais vinculado ao CCR e $o$ Search for Common Ground. (ODEDAAL; HONWARA, 2005) Observa-se, então, que o envolvimento dos atores burundineses não era com o CCR, mas com a figura de Van Eck, o que tornava o processo de mediação de segunda via extremamente fraco.

Em outubro de 2002, foi assinado o acordo de cessar-fogo com dois grupos rebeldes menores. Contudo, os dois maiores grupos rebeldes Hutus - FDD e o FNL (Forces Nacionales de la Libération) - continuaram a luta armada contra o governo. Em outubro de 2003, o governo assinou o cessar-fogo com a FDD, deixando a FNL como único grupo armado em conflito armado contra o governo. Em 2004, a força de paz da União Africana foi substituída pela Missão de Paz da ONU. As eleições, as quais deveriam ocorrer neste ano, foram adiadas para abril de 2005, devido às tensões no país. (BRACHET; WOLPE, 2005, p. 2)

A nova Constituição, promulgada em 28 de fevereiro de 2005, estabelecia a divisão de poder entre os partidos étnicos em $60 \%$ Hutus e $40 \%$ Tutsis, e um novo governo e o Parlamento foram eleitos. O ex-grupo rebelde, CNDD-FDD e seu líder, Pierre Nkurunziza, chegaram ao poder, após as eleições legislativas, municipais e dando fim ao processo de transição. (PROJECT PLOUGHSHARES) É fundamental ressaltar que a divisão do poder por porcentagem na Constituição não é a solução perfeita e final para as tensões étnicas no Burundi. No entanto, é o início de um longo e trabalhoso processo de reconciliação da sociedade, o qual tem que envolver todos os níveis da sociedade e ser acompanhado por observadores e mediadores internacional, papel o qual as ONGs podem realizar. 
Em 14 de maio de 2008, o acordo de cessar-fogo com a FNL foi assinado. Todavia, os dois lados têm acusações de violação ao acordo de cessar-fogo. A luta ativa parou em abril de 2009, quando o FNL se tornou um partido político. Em junho do mesmo ano a FNL formalmente assumiu cargos do governo, juntando-se a CNDD-FDD. Essa integração é preocupante, pois muitos desses líderes não foram preparados para o governo e cometeram crimes de guerra. (PROJECT PLOUGHSHARES) Como coloca Human Right Watch:

"The national consultations process should not distract attention from the fact that in the nine years since Arusha, the government has made very little progress toward establishing transitional justice mechanisms in line with international law," (HUMAN RIGHT WATCH, 2009)

No Burundi não ocorreu nenhum processo de verificação dos crimes cometidos durante a guerra de acordo com as leis internacionais. Na realidade, muito desses crimes foram perpetrados por participantes do governo.

A situação dos jovens da FNL é preocupante, pois eles continuam armados, sendo em sua maioria com armas ilegais. Isto porque milhares de pessoas, que se associaram do ex-grupo rebelde FNL, foram excluídos do programa de DDR. (PROJECT PLOUGHSHARES) Esse é um dos elementos básicos para o Burundi voltar ao conflito armado, caso o acordo de paz não consiga êxito.

Os esforços para reintegrar os ex-combatentes nas forças armadas ou na polícia são irregulares. Um dos fatores para isto, é que um exército muito grande pode ser um fator desestabilizaste para o país. Para agravar a situação de segurança, tanto o governo como a oposição foram acusados de mais de 100 ataques com granada que resultaram em mortes, em 2010. (HUMAN RIGHT WATCH)

O período de eleição foi marcado por medidas de violência tanto pela oposição como pelo governo. Além disso, com poucas exceções, os partidos de oposição não ofereceram uma nova visão política para o Burundi. Eles limitaramse, normalmente, a responder à pressão de segurança que a escalada de provocações verbais e a acusar o CNDD-FDD de corrupção e prática autoritárias, sem realmente mostrar que uma vez no poder eles agiriam de forma diferente. (GRIGON, 2010) 
Desde o boicote às eleições, por parte da oposição, a qual acusava as eleições de falhas, apesar dos observadores internacionais considerarem que ela foi razoavelmente justa. Sem adversários, o Conselho Nacional para a Defesa da Democracia e as Forças para a Defesa da Democracia elegeram o seu candidato à presidência com $91 \%$ dos votos. Obtendo a esmagadora maioria em ambas as casas do Parlamento. (THE ECONOMIST, 10 de março de 2012)

Em decorrência disso, parte da população exilou-se ou refugiou-se. Sendo que tem indícios do líder da Frente de Libertação Nacional, Agathon Rwasa, estar baseado no leste da República Democrática do Congo, visto que tropas leais a ele começaram a juntar-se com outras milícias e grupos rebeldes nesta região. Nos últimos meses de 2011 e inicio de 2012, líderes de outros dois movimentos armados exilados anunciaram a intenção de derrubar o poder.

Grupos de direitos humanos dizem que cerca de 300 membros da oposição foram mortos e dezenas presos desde julho de 2011. O governo atacou a mídia independente e acusou ativistas e advogados da sociedade civil a incitar o terror. Em contrapartida, líderes do Burundi recusam-se a admitir que haja uma rebelião em andamento.

Até o momento, os grupos rebeldes ainda são incipientes com falta de recursos humanos, organização e visão. Todavia, o local onde eles estão instalados é instável e suscetível a rebeliões, favorecendo assim o objetivo deles.

Temendo uma guerra civil, diversos atores burundienses, incluindo o clero católico, membros da oposição não-violenta e o ex-Chefe de Estado, Sylvestre Nitabantunganya solicitaram o diálogo. O governo diz que dialoga se a oposição voltar do exílio. Entretanto, muitos duvidam da sinceridade do governo. O Burundi está entre os países mais pobres do mundo, porém as suas autoridades desfrutam de uma vida de luxo. A Transparência Internacional ${ }^{29}$, uma organização da sociedade civil internacional com sede em Berlim, diz que o Burundi é o país mais corrupto de região. Por outro lado, os rebeldes ganham dinheiro com tráfico de ouro e proteção de contrabando.

\subsection{Conclusão}

\footnotetext{
${ }^{29}$ A International Transparency é uma organização da sociedade civil internacional de combate à corrupção, criada em 1993, com sede em Berlim.
} 
O conflito no Burundi iniciou-se em 1972 com o primeiro genocídio Hutu no país, apesar das tensões já estarem presentes desde 1965. Contudo, após esse acontecimento o conflito só reiniciou em 1988. A despeito desse longo intervalo entre os dois, eles possuem profundas interligações, considerando que a estrutura e organização da sociedade não modificou-se. Inclusive uma das causas do conflito ter eclodido em 1988 foi a memória e o ódio devido o genocídio de 1972. Durante o período de trégua entre os dois conflitos a minoria Tutsi dominou a política e isolaram os Hutus, os quais muitas vezes se refugiaram e organizaramse no campo de refugiados.

O regionalismo tem grande influência no conflito do Burundi, por localizar-se em uma das regiões mais vulneráveis do mundo, onde a formação de grupos armados é simples e fácil. Além dos conflitos intervirem entre si, por exemplo, Ndayikengutukiye retirou-se unilateralmente das negociações por ter sido convidado por Kabinda a participar da segunda guerra na República Democrática do Congo. (NIJIMBERE, 2004, p. 2)

A situação regional só torna mais complexa a mediação. A mediação no Burundi foi realizada por três ONGs, as quais tiveram comportamento e estratégia diferentes. A Center for Conflict Resolution (CCR) juntamente com o Search for Common Ground tiveram um papel mais caracterizado como mediação de segunda via, voltada para a quebra de estereótipos, mais informal e com ações mais criativas, apesar de ter atuado diretamente nas negociações não-oficiais entre o governo burundiano e a FNDD-FDD. Já a Comunidade Sant'Egidio trabalhou dentro da mediação oficial com o mediador principal. O mediador principal era o Julius Nyerere, ex-presidente da Tanzânia, e posteriormente, Nelson Mandela, expresidente da África do Sul. A mediação ainda contou com a participação de países da região - como Quênia, República Democrática do Congo e Etiópia -, os Estados Unidos da América, a União Européia e a ONU.

A participação de vários tipos de atores na mediação foi mal administrada e faltou coordenação, os mediadores não possuíam os mesmos objetivos, resposta e estratégia, pelo contrário eles debatiam entre si e disputavam a atenção dos mediados, enfraquecendo a mediação. Os mediadores precisam manter o diálogo e a coordenação constante, pois as partes perdem a confiança no mediador quando recebem influências contraditórias, deixando a mediação confusa. (ver CHIGAS, 2007, p. 571) A coordenação não deve limitar-se aos mediadores que atuam na 
mediação oficial, mas tem que envolver também os atores que trabalham na mediação informal e de segunda via.

Um dos grandes problemas da mediação, além da falta de coordenação dos mediadores, foi a incapacidade deles em conseguir mudar a perspectiva das partes. Os Hutus e Tutsis tinham medo um do outro, não devido a uma história de ódio e medo que provem de séculos, visto que antes da independência eles respondiam a um único rei, mas devido a acontecimentos recentes e à utilização étnica para outros fins, tais como ganho econômico e controle da máquina estatal.

A mudança de perspectiva era fundamental para conseguir construir uma sociedade de paz no Burundi, é construir uma sociedade pacifica baseada no medo e na negação de acontecimentos tão significativos como os genocídios, os quais o governo tenta retirar da história do país.

Apesar de conseguirem atingir o acordo de paz, ele era poroso e fraco, e não determinava quem realizaria o processo de transição para o novo regime. Além disso, não conseguia mudar a organização da sociedade, tinha somente uma divisão de poder governamental fraco, não resolvendo a propagação do medo e desconfiança da sociedade. Na realidade, a mediação não trabalhou nem mesmo com todos os níveis sociais, ela focou-se mais nos líderes principais. Nem o trabalho mais informal realizado pelo CCR e o Search for Common Ground conseguiu atingir toda a sociedade, apesar de eles tentarem chegar as reais causas do conflito, se envolverem e ouvir os burundianos, eles limitaram o seu projeto aos líderes e a mudança das perspectivas deles, o que não foi bem-sucedido. Como colocado no capítulo 1 , os conflitos complexos precisam realizar a mediação no modelo piramidal, no Burundi isto era ainda mais essencial, pois os genocídios não foram somente realizados pelo governo e as suas forças armadas, mas também pela população em geral. Ou seja, a população sofria e realizava a violência tornando ainda mais importante a implementação de um longo trabalho com ela.

Outro gravíssimo erro dos mediadores foi a realização da mediação e a assinatura do acordo de paz sem a presença de todos os atores na mesa de negociação, situação que foi agravada pelo fato de que os dois grupos que estavam fora da mediação eram simplesmente os dois principais grupos armados contra o governo. O mediador precisa saber quando o conflito está maduro para ele poder atuar e caso o mediador deseje começar a sua ação antes do momento de 
maturação do conflito, é necessário que ele tenha uma estratégia que faça com que as partes desejem a mediação. O que não é possível é que assine-se um acordo de paz onde dois dos principais atores do conflito não estejam de acordo, isso só faz com que o acordo seja fraco e vazio. Até mesmo porque em um Estado falido, como é o caso do Burundi, o Estado não tem autoridade para implementar o acordo e precisaria do auxilio e da legitimidade dos demais atores no conflito para realmente fazer com que o acordo seja respeitado. Então, quando duas das principais partes não assinaram, não concordam e não pretendem o cumprir o acordo, este está fadado ao fracasso antes mesmo de ser implementado.

O resultado foi o fracasso do acordo; a não transformação do conflito em político, principalmente devido aos radicais de cada etnia; a utilização da fronteira com a República Democrática do Congo para organização de tropas e violência considerável durante as eleições. 


\section{5. Conclusão}

Conclui-se que os conflitos complexos possuem características que influenciam fortemente a mediação internacional, trazendo desafios e limitações, que precisam ser respondidos. Os conflitos complexos nascem em Estados falidos, nos quais as instituições são fracas ou inexistentes; e onde a tensão entre autodeterminação e construção do Estado é latente, em um sistema internacional dominado pela globalização e sofrem influência das questões regionais.

Questões regionais são marcantes em todos os conflitos analisados, ao longo desta dissertação. No caso de Moçambique, a formação da RENAMO teve como um dos principais atores a Rodésia (atual Zimbábue); no conflito do Aceh, atores internacionais não tiveram interesse em intervir na primeira rodada devido à missão de paz das Nações Unidas no Timor-Leste, a mais importante na época; e o Burundi que se localiza na região dos Grandes Lagos na África, uma das regiões mais instáveis do mundo e com sérios conflitos de identidade.

Eles possuem como características: a fragmentação da sociedade e militar, utilização de estratégia de guerrilha e armas leves; a presença constante de atores ilegítimos; os desrespeitos aos direitos humanos e o ataque a civis como arma de guerra; a falta de definição clara para os beligerantes; com a propagação do terror e ódio ao "outro" em toda a sociedade; a destruição da infraestrutura estatal; a crença por parte dos insurgentes de que o único modo de conseguir que as suas reivindicações sejam ouvidas e atendidas é pela luta armada; a fluidez do poder; a falta de demarcação de onde se inicia e de onde termina o conflito e a mudança rápida da situação do conflito. Consequentemente, o conflito envolve todas as camadas da sociedade e faz com o Estado esteja destruído socialmente e materialmente após ele. Obviamente, os conflitos complexos não precisam apresentar todas estas características, no entanto, a maioria delas estará presente no conflito e no seu desenvolvimento.

As características tratadas nesta dissertação e que envolvem a mediação internacional relacionam-se às questões internas do conflito. Isso não significa que as questões externas envolvendo o conflito, tais como contrabando de armas, comércio ilegal de recursos naturais e financiamento dos senhores de guerra através desse comércio são desconsiderados. No entanto, a mediação de ONGs 
não tem capacidade de ligar com esses aspectos e a mediação no seu sentido mais restrito se refere a intervenção na relação entre as partes em conflito e a resolver as questões internas do conflito.

Sendo assim, a mediação internacional não pode ser realizada de forma tradicional, burocrática e com estratégia fixa. Ela deve ser flexível, criativa, adaptável as novas situações apresentadas, inclusiva a todos os atores do conflito sendo eles legítimos ou não. Somente a partir de mudanças significativas na constituição e dinâmica da mediação será possível a esta responder às novas necessidades dos conflitos.

Neste contexto, as ONGs possuem vantagens e limitações frente aos Estados, organizações internacionais e regionais. É importante frisar que todos os atores capazes de fazer a mediação têm vantagens e limitações, as quais devem ser consideradas no momento de análise do melhor mediador para o determinado conflito. Como colocado por Chigas, as ONGs possuem baixa burocracia que reflete em rápida resposta ao conflito e no processo decisório e maior flexibilidade nas estratégias e adaptação aos acontecimentos no conflito. (CHIGAS, 2007, pp. 556-557) A resposta rápida e a adaptação ao conflito são essenciais, pois os conflitos complexos têm a tendência de serem altamente voláteis tanto nos acontecimentos como nos detentores do poder, ou seja, a situação do conflito modifica-se constantemente e rapidamente transformando as forças dentro dele e as autoridades que respondem por elas. Os processos realizados pelas ONGs objetivando desenvolver novas opções para diminuir a polarização ou concorrência de soluções, podem gerar ideias criativas para solucionar problemas que não podem ser suscitados em negociações com atores tradicionais.

As características dos conflitos complexos fazem com que fatores constituintes da mediação tenham um maior destaque. Nesse contexto, a mudança de percepção ganha força, pois é necessário mudar a percepção das partes em relação a outra, a forma de solicitar as suas reivindicações e de toda a sociedade. Considerando que ela está envolvida em um ambiente de ódio e medo que não é capaz de realizar a reconciliação e a construção de uma sociedade que resolve os conflitos politicamente ou por meio de instituições específicas. É importante compreender que o conflito não se limita ao conflito armado, mas a toda uma gama de conflitos sociais que, naturalmente, estão presentes na sociedade e os quais a ajuda a desenvolver. 
Apresenta-se, assim, uma das vantagens das ONGs na mediação, pois, segundo Chigas, as ONGs são capazes de lidar com as partes mais subjetivas e sócio-psicológicas do conflito. Os mediadores tradicionais não possuem esta capacidade, porque os instrumentos disponíveis e utilizados por eles na negociação, mediação e gestão de conflitos são burocratizados, elitizados, rígidos e inadequados para a abordagem desses aspectos do conflito. Em compensação, o mais observado nas mediações realizadas pelas ONGs é a quebra de estereótipos negativos e generalizações. Os participantes percebem a diversidade de pontos de vista em ambos os lados, incluindo visões que atravessam as linhas do conflito e identificam a "coligação de parceiros" do outro lado, o que vai permitir a abertura de canais de negociação, ou seja, percebe-se que as opiniões dentro de cada grupo não são unas e possuem sub-grupos que podem partilhar dos mesmos interesses de outro sub-grupo dentro de outro grupo o que permite a abertura de canais de negociação. As ONGs tendem a ser mais bem adaptadas para a mediação de conflitos, os quais precisam primeiramente da mudança de perspectiva, pois podem construir um local de negociação com menor pressão política, mais criatividade, uma interação informal entre os participantes e consegue envolver toda a sociedade por meio de diversos projetos. (pp. 553-556)

A desmitificação da outra parte como inimigo ou terrorista é fundamental para a construção da paz sustentável. Somente com esta mudança é que se consegue construir uma sociedade após o conflito. Em dois conflitos analisados como bem-sucedidos durante esta dissertação, Moçambique e Aceh, as ONGs mediadoras conseguiram mudar a perspectiva no conflito. No primeiro caso, a Comunidade Sant'Egidio conseguiu construir uma história em que todos definiam-se como parte da grande "família moçambicana". No segundo caso, a Conflict Management Initiative conseguiu modificar a visão de ódio contra a Indonésia por parte da região do Aceh e retirou o rótulo de terrorista utilizado contra o GAM. Em contrapartida, não foi possível modificar as perspectivas no Burundi, um dos grandes motivos é que a mediação não foi bem-sucedida, os genocídios de 1972 e 1994 ainda não pertencem à história burundiana, segundo o governo.

A cultura é outro fator que ganha importância frente à mediação deste tipo de conflito tanto como um dos fatores fundamentais na definição do perfil das partes, no modo de organização da sociedade, como e, principalmente, para a 
criação de pontes de identificação das partes com o mediador, o que possibilita uma relação de confiança mais forte (RICHMOND, 1998, pp. 707-712) Em consequência à relação de confiança, o mediador torna-se legítimo e a mediação mais fácil devido a maior aceitabilidade pelas partes às sugestões do mediador e a maior abertura em negociação com a outra parte. Tal qual colocado por Natsios, as ONGs possuem maior conhecimento sobre a cultura, pois, normalmente, estão envolvidos no contexto há muitos anos, como é o caso da Comunidade Sant'Egidio em Moçambique, e dessa forma estão familiarizados com a linguagem e práticas culturais do país em conflito, além disso eles podem relacionar-se com uma gama de atores civis. A consequência disto é que o mediador pode ganhar a confiança das partes em conflito, adaptar as suas abordagens à cultura e conseguir reconhecer e identificar quais são as estratégias ideais para serem implementadas no conflito, facilitando o processo efetivo de mediação. (NATSIOS, 2007, pp. 343-344) (ver KLEIBOER, 1996, p. 369)

As redes de conhecimento ganham destaque neste sentido (LANZ; SGUAITAMATTI, 2009, p. 6), pois, através delas que as ONGs conseguem envolver-se na sociedade e conhecer a sua cultura, costumes e crenças. Ao mesmo tempo, que é por meio dela que a ONG consegue penetrar a mediação em todos os níveis sociais. (ver LEDERACH, 1997)

A incorporação de temas anteriormente considerados como irrelevantes, com religião, é outra das mudanças importantes na mediação. A religião gera conflitos e influencia o comportamento das partes, assim é fundamental compreendê-la para entender a relação mediador e mediado. A religião pode contribuir ou não para a identificação entre as partes e o mediador. Além disso, as autoridades religiosas podem ser a única autoridade reconhecida nas comunidades; sendo assim, o mediador pode utiliza-se da rede religiosa para conseguir entrar nas comunidades mais afastadas e poder realizar os seus projetos. (NATSIOS, 2007, p. 358)

No caso de Moçambique a importância da religião ficou evidente, pois a sociedade moçambicana é extremamente religiosa e católica, o que ajudou a fazer com que a Comunidade Sant'Egidio, ONG religiosa ligada ao Vaticano, tivesse identificação com as partes e inserção na comunidade. $O$ envolvimento do Vaticano, que foi coordenado pela Comunidade, em favor da mediação, como foi 
o caso das duas visitas do Papa em Moçambique ajudou a dar maior força à mediação e chamar a atenção internacional.

Isso não quer dizer que a identificação entre o mediador e os mediados tenha que passar necessariamente pela religião. Este é somente um dos possíveis fatores de identificação. No entanto, a identificação entre eles facilita a abertura do diálogo. Por exemplo, no caso de Moçambique, o Bispo Gonçalvez e Dhlakama, líder da RENAMO, descobriram que pertenciam à mesma tribo, o que possibilitou uma maior abertura de comunicação com a RENAMO utilizando-se do Bispo como intermediário nas negociações, eles, em alguns momentos, negociaram em sua língua natal e lembravam histórias da tribo. (BARTOLI, 1995, pp.94-95)

Nos dois conflitos considerados como mediação bem-sucedida e analisados nesta dissertação, o mediador da ONG, apesar de ser o principal, não foi o único a intervir no conflito, pelo contrário, existiu uma multiplicidade de atores intervindos, como o Vaticano, o governo italiano e a Organização das Nações Unidas em Moçambique; e o conflito do Aceh teve o apoio da União Européia e países da ASEAN, bem como chamou atenção internacional.

O envolvimento de diversos atores não é necessariamente prejudicial para a mediação. Porém, devido à diversidade de atores presentes, é necessário que haja uma coordenação e que ela parta do mediador principal. O mediador principal teria então o papel de ser o coordenador, o capaz de entrar em contato com os diversos níveis do conflito e com os diferentes tipos de atores envolvidos na mediação para assim suprir as indigências da mediação. Considerando, assim, o mediador principal não precisa ser aquele mais poder, mas ser o com maior capacidade de coordenar a ação dos diversos atores, ter a confiança das partes, conseguir começar e manter o diálogo entre as partes e o entendimento profundo sobre a dinâmica do conflito e das suas forças. Caso contrário, se a coordenação não for bem feita, os mediadores entrarão em conflito e a mediação enfraquecerse-á, como ocorre na mediação do Burundi. (BRACHET; WOLPE, 2009, p.2) (ver CHIGAS, 2007, p. 571)

O imperativo da existência de mais de um tipo de mediador na intervenção do conflito é em decorrência de nenhum tipo de mediador conseguir suprir todas as exigências desse tipo de conflito. Devido a isto, a coordenação é fundamental, visto que somente com ela as respostas dos mediadores vai ser sólida frente o 
conflito. Como mostra as mediações em Moçambique e Aceh, a intervenção de diversos atores não é prejudicial.

Apesar da existência de diversos atores ser considerada um ponto positivo, a mediação de conflitos complexos não deve ser entendida como a defendida por Diamond e Mcdonald, chamada de Multi-Track. No Multi-Track, todas as faixas de mediadores são vistas com igualdade, não tendo um mediador principal. Segundo eles, todos os atores possuem a mesma importância na mediação e a coordenação é feita através de divisão de tarefas e sobreposições. Em todos os casos estudados nesta dissertação, em nenhum a mediação de Multi-Track foi utilizada; em todos existiu um mediador principal, o qual recebeu auxílio de outros atores.

O modelo de mediação ideal para os conflitos complexos é o defendido por Lederach, o modelo piramidal. O modelo piramidal não se centra somente nos líderes e tomadores de decisão, mas engloba toda a sociedade, devido a isto é que este modelo é o desejado para os conflitos complexos. (LEDERACH, 1997) Visto que este tipo de conflito atinge diretamente ou indiretamente toda a população, a propagação do ódio e do medo e o ataque a população civil faz com ela também esteja envolvida diretamente no conflito e precise passar por um processo de reconciliação tanto quanto os líderes e os membros dos grupos armados. (MÜNKLER, 2005, pp. 10-15)

As ONGs possuem melhores condições para integrar os interesses civis na negociação, os quais são tradicionalmente excluídos, fomentando a diversidade nas negociações, pois são atores da sociedade civil, sendo ela internacional ou não. Muitas vezes, as ONGs já estão adaptadas e engajadas localmente para a construção de círculos de paz. Elas também são qualificadas na promoção de diálogo entre os líderes do nível médio, os quais podem influenciar as partes em conflito para a negociação e a implementação do processo de paz. As ONGs ainda têm o importante papel de dialogar com entidades civis conjuntamente as negociações oficiais. (LANZ; SGUAITAMATTI, 2009, p. 8) Duas outras ferramentas para a realização do modelo piramidal são as redes de conhecimento e a coordenação dos atores, o qual já foi falado. A coordenação é fundamental na mediação internacional devido à amplitude do processo, o que é impossível somente um ator conseguir trabalhar em todas as frentes da mediação. 
As redes de conhecimento são uma das vantagens das ONGs, pois normalmente elas já trabalham no país que irão realizar a mediação e possuem uma rede de conhecimento tanto devido ao seu próprio trabalho, como através do relacionamento com outras ONGs que trabalham no local e a rede internacional de ONGs que existe com trocas de experiência. Por exemplo, no caso de Moçambique, a Comunidade Sant'Egidio possui uma rede de conhecimento devido aos dois fatores. Primeiramente, a Comunidade Sant'Egidio é uma organização católica e devido a isto conhecia - anteriormente à mediação membros da Igreja Católica Apostólica Romana moçambicana, como o Bispo Gonçavez, podendo, assim, contar com todo o conhecimento e relações que a Igreja e o Bispo tinham em Moçambique, e chegando assim a lugares e grupos que outros mediadores não conseguiriam. Em segundo lugar, ela iniciou o trabalho humanitário em Moçambique em 1976, permitindo assim que se desenvolvesse relacionamento com as duas partes do conflito e com a sociedade moçambicana. (BARTOLI, 1995, pp. 84) Ao mesmo tempo, em que a falta de relacionamento pode fazer com que a mediação seja aceita, como ocorreu com a Henry Dunant Center for Humanitarian Dialogue no Aceh. Todavia, quando isto ocorre, a ONG vai estar com menos poder dentro da mediação e a sua margem de manobra é menor, impedindo-a de alcançar alguns objetivos durante a mediação, como aconteceu na primeira rodada desse conflito. (AALL, p. 478)

Como colocado no primeiro capítulo, a imparcialidade ou não do mediador é um dos temas mais debatidos e controversos da teoria de resolução de conflitos. Muitos acreditam que a imparcialidade é fundamental, principalmente tratando-se de ONG, que não possui o poder econômico e da coerção. (BERCOVITCH; SCHNEIDER, 2000, p. 148) Considerando que os outros autores que não acreditam na imparcial como primordial, acreditam que eles precisam utilizar os seus poderes para auxiliar a mediação e conduzir os mediados. Ainda tem os que acreditam que a imparcialidade não é o mais fundamental, mas a escolha e manutenção do mediador estão mais associadas ao relacionamento e a conexão de confiança das partes com o mediador. (KLEIBOER, 1996, pp. 369-370)

A imparcialidade tem a sua importância, mas ela não precisa ser aplicada em todos os momentos e em todos os níveis do conflito. O mais importante é que as partes não considerem que o mediador esteja privilegiando a outra parte da mediação; caso isto ocorra, o mediador pode perder os seus poderes frente as 
partes, visto que eles são dados pelas partes, e não poderá influenciar na mediação. Todavia, mesmo a corrente que defende a imparcialidade do mediador como fundamental, coloca que este deve influenciar a mediação para ser possível mudar a perspectiva das partes e da sociedade, conseguindo assim construir a paz. Além disso, quando as partes não estão em situação de igualdade, o mediador deve tentar resolver a assimetria de poder ou então solicitar que outro ator faça o papel de advogado de uma das partes para que o mediador principal não perca a sua legitimidade na mediação. (ver JONES, 1999, p. 59)

No caso do Burundi, o principal mediador, Julius Nyerere, não era visto como imparcial devido às suas ações durante e antes da mediação. Ele tinha apoiado e ajudado a implementar o embargo econômico sobre o Burundi e durante a mediação as suas ações tendiam para o Hutus. Consequentemente, os Tutsis o considerava tendencioso, no entanto, permaneceram na mediação. Julius Nyerere tinha um relacionamento com os burundianos e tinha sido até mesmo solicitado anteriormente para mediar o conflito pela ex-presidente burundiano, mas ele não tinha conseguido desenvolver uma realidade de confiança tão forte que as suas ações antes da mediação não interviesse nela.

A legitimidade do mediador não provém somente da sua imparcialidade ou não. Na realidade, a legitimidade decorre mais da relação de confiança entre o mediador e as partes, que pode derivar de um longo relacionamento do mediador com as partes ou da crença de que aquele é o melhor mediador para a situação. (NATSIOS, 2007, p. 344)

O poder do mediador é um dos pontos mais relevantes quanto se trata de mediação realizada por ONGs, pois a maior crítica e limitação em relação às ONGs é a falta de poder econômico e militar. As ONGs possuem o poder referente, informacional, perito e legítimo, sendo este último derivado do seu relacionamento forte com as partes ou de outro fator de legitimação que esteja acompanhando o mediador. Mas, como já foi falado, a falta de poder militar e econômico pode ser benéfico ou não para a mediação, depende de como o conflito se desenha e como o mediador vai lidar com isto. Um grupo de estudiosos coloca que a falta desses dois poderes pode funcionar como um obstáculo, caso as partes não desejem negociar, o que não é difícil ao tratar-se de conflitos complexos, visto que as partes têm ganhos econômicos com o conflito, pois o mediador não terá nenhum poder que possa incentivar fortemente a mediação. 
No entanto, o mediador pode solicitar ajuda a outro mediador, como os Estados, caso isto aconteça. Na mediação do Aceh a CMI, teve que solicitar a ajuda de Estados para realizar a Missão de Vigilância no Aceh (MVA), considerando que eles teriam mais poderes necessários neste momento do processo. Ao mesmo tempo, pelo fato de ONGs não terem esses dois poderes, as partes podem sentir-se menos pressionadas e aceitar a mediação mais facilmente; isto foi essencial no mesmo conflito, pois o governo indonésio nunca aceitaria um mediador poderoso para realizar a mediação com um grupo considerado por ele como terrorista. (CHIGAS, 2007, p. 562) (LANZ; SGUAITAMATTI, 2009, pp. 9-10)

É verdade que a mediação das ONGs é deficiente quanto a esses dois poderes; porém, também é verdade que o mediador só possui os poderes que as partes dão a eles, ou seja, eles só podem usar os seus poderes se as partes consentirem com isto e com a mediação de forma geral. Além disso, o poder de barganha ou financeiro pode gerar dependência às partes e fazer com que as partes aceitem o acordo somente devido aos ganhos que teriam com ele, sendo altamente prejudiciais a mediação e o oposto de uma solução real para o conflito. O poder coercitivo pode ser desvantajoso caso as partes sintam-se ameaçadas ou pressionadas por este pelo mediador, podendo acontecer o mesmo que com o poder financeiro e de barganha, o que não é vantajoso para a mediação. Percebese, então, que a falta dos poderes de barganha e coercitivo são favoráveis, porém, existem outros momentos em que a utilização desses dois poderes são fundamentais para o mediadores alcançarem um acordo de paz; contudo, o mediador de ONG pode solicitar o apoio de outro mediador neste momento ou ainda pode ser avaliado que este conflito não é para ser mediado por uma ONG, lembrando que sempre deve ser analisado qual o melhor mediador para o conflito. Sendo assim, percebe-se a necessidade de analisar profundamente cada conflito para saber qual a forma de mediação que melhor se aplica a ele.

As diferentes motivações dos mediadores podem fazer com que os mediadores não-oficiais, ou melhor, de ONGs, desempenhem um valioso papel onde os mediadores oficiais ou tradicionais estão indisponíveis, desinteressados, (AALL, 1996, p. 3) ou são vistos como tendenciosos pelas partes ou elas têm receio quanto ao "fator legitimador". (MITCHELL, 1992, p. 277) Pois, as ONGs não têm a sua motivação baseada em poderes políticos e auto-interesse, o seu 
interesse baseia-se em acreditar que o melhor resultado possível para a sociedade ou para manter a sua reputação de boa mediadora. Deve-se ressaltar que, em algumas situações, as ONGs podem atuar devido ao interesse dos seus doadores, os quais podem ser Estados, no entanto, mesmo, nestes casos, os Estados não têm interesse ou capacidade de intervir diretamente no conflito, precisando utilizar-se das ONGs. (ZARTMAN; TOUVAL, 2007, p. 442)

Os conflitos analisados nesta dissertação podem dar luz a alguns pontos da teoria de resolução de conflito. Os conflitos, de mediação bem-sucedida estudados aqui tiveram o seu momento de maturação aproveitado pelos mediadores de ONG. No caso do Aceh, ficou mais clara a necessidade das partes estarem preparadas para a mediação para que o acordo fosse bem-sucedido. Na primeira rodada de mediação, as partes não tinham um real comprometimento com a mediação, o que foi agravado pela falta de análise e sensibilidade por parte da Henry Dunant Center for Humanitarian Dialogue cuja percepção do conflito era completamente distorcida e exigia mais comprometimento das partes, mesmo quando os acordos anteriores eram violados. A questão da maturação do conflito é agravada pela falta de poder econômico e coerção por parte dos mediadores de ONG. Pois, como eles não possuem esses poderes não conseguem incentivar fortemente as partes a se comprometerem com a mediação, resultando em um processo de maturação do conflito mais longo e trabalhoso ou na solicitação por parte do mediador de ONG do auxilio de outro tipo de mediador. Em oposição, a CMI teve maior facilidade em conseguir realizar a mediação, uma vez que as partes estavam dispostas para as negociações. (HUBER, 2004, p. IX)

No conflito de Moçambique, podemos perceber o trabalho realizado pela Comunidade Sant'Egidio para levar as partes a desejarem e comprometerem-se com a mediação após 13 anos do conflito. A Comunidade trabalhou com os dois lados do conflito, não somente mostrando a mediação como a melhor solução para o conflito, mas também para tentar igualar as forças entre as duas partes antes da mediação.

O trabalho realizado anteriormente às negociações também foi muito importante para a mediação. Apesar de ser considerado como sendo parte da mediação de segunda via o preparo da mediação, no caso de Moçambique foi a Comunidade Sant'Egidio que se responsabilizou por ele. Quando o mediador principal é uma ONG, a parte oficial e informal da mediação confundem-se, 
porque, normalmente, é o mesmo mediador que realiza simultaneamente ou não os dois processos, devido ao ambiente de baixa pressão política oferecido pela ONG, o qual é o ideal para experimentar ideias criativas, ao mesmo tempo, que a mediação oficial é realizada.

Anteriormente a mediação foi realizado um longo trabalho com a RENAMO e a FRELIMO por parte da Comunidade, o que foi fundamental para ambos reconhecerem as reivindicações do outro como sendo legítimos para a mediação. O processo anterior realizado em Moçambique com os dois grupos só foi possível pela Comunidade Sant'Egidio ser uma ONG que não sofre pressão política quando se relaciona com grupos considerados como ilegítimos, terroristas ou desrespeitadores dos direitos humanos, como era o caso da RENAMO. Além disso, não existia o risco da RENAMO utilizar-se do "fator de legitimação" apresentado por Barnett. A mediação no Aceh também só foi possível devido à ONG não sofrer tanto com o custo político de se envolver com atores considerados ilegítimos, pois o GAM era considerado um grupo terrorista e só foi considerado como um ator legítimo após as negociações, apesar de o governo indonésio tê-lo considerado como sendo um ator passível de negociação.

O trabalho pré-mediação foi fundamental para a criação de uma relação de confiança entre a Comunidade e as partes, o que no caso das ONGs é um fator primordial para o mediador possuir o poder legitimador, como coloca Aall. O trabalho realizado não criou somente uma relação de confiança, mas também permitiu que a mediação fosse realizada de forma mais fácil, com as partes mais abertas à negociação e às sugestões da Comunidade. Em acréscimo, as partes estiveram disponíveis para o mediador utilizar outros recursos: controlar os locais das negociações, determinar a agenda, convidar outros mediadores e utilizar os seus poderes referencial e informacional. A CMI também utilizou-se desses recursos na mediação do Aceh, enquanto a Henry Dunant Center tentou utilizar-se deles, mas não foi bem-sucedida em conseguir angariar apoio internacional para a mediação. Já o Center for Conflict Resolution e o Search for Common Group não conseguiram utilizar esses recursos, o projeto foi realizado no Burundi dentro do ambiente de ódio e medo pelo outro.

A identificação entre o mediador e as partes foi um dos fatores de sucesso na mediação em Moçambique, além da questão religiosa - os moçambicanos são católicos e a Comunidade também -, membros que trabalham em conjunto com a 
Comunidade eram moçambicanos e compartilhavam da mesma cultura auxiliando extremamente a mediação.

O trabalho da Comunidade Sant'Egidio não somente com as partes, mas também o trabalho humanitário, fez com que se criasse uma forte rede de conhecimento, que englobava não somente a Igreja Católica Moçambicana como também líderes locais. Essa rede de conhecimento é uma das maiores vantagens que as ONGs possuem na mediação, principalmente nos conflitos complexos, pois na resolução de conflito pelo modelo piramidal é necessário que exista um conhecimento prévio dos vários níveis do conflito, ou seja, é preciso que o mediador conheça não somente os líderes dos grupos em conflito, mas também todos os níveis desses grupos e toda a sociedade. Essa rede de conhecimento ainda possibilita ao mediador conhecer profundamente a cultura e costumes das partes, o que é importante no momento das negociações para não haver nenhum desentendimento de comunicação e para o mediador conseguir resolvê-los no momento em que ocorre.

O mais importante fator de sucesso das mediações foi a capacidade das ONGs em coordenar o trabalho de diferentes atores na mediação, os quais estavam voltados para alcançar o mesmo objetivo, impedindo assim que existisse competição entre os mediadores e que as partes mudassem de mediador como forma de pressão sobre eles. Tanto a Comunidade Sant'Egidio como a CMI souberam coordenar e solicitar a participação de diversos atores na mediação no campo político e financeiro.

O objetivo da mediação em Moçambique e no Aceh não se limitava à assinatura do acordo de paz, mas entendia que somente com a resolução real das causas do conflito é que se poderia resolvê-lo. Segundo o relatório solicitado pelo Conselho de Segurança, Realizing the Strengths and Mitigating the Challenges of NGO Mediators, as ONGs por serem baseadas em valores têm o seu trabalho percebido dessa maneira. A Comunidade Sant'Egidio tinha como objetivo a transformação democrática de uma sociedade em conflito armado, na qual os futuros litígios seriam resolvidos pelas vias pacificas. A CMI objetivava a inserção das reivindicações na política da Indonésia, transformar o conflito para político, a implementação de instituições de resolução de conflito, 
abrindo assim locais para o debate das reivindicações futuras sem a necessidade do conflito armado.

Ao contrário desses dois exemplos, a mediação no Burundi foi um fracasso não somente pela incapacidade do Center for Conflict Resolution (CCR) e o Search Common Group de persuadir as partes para poder utilizar os seus recursos como mediador, tal como a escolha do local da mediação. A mediação dessas duas ONGs foi o que podemos classificar como mediação de segunda via, a qual é auxiliar à mediação principal. (JONES, 1999, p. 59), apesar do papel mais ativo que ele fez nas negociações entre o CNDD-FDD e o governo indonésio de forma secreta e longe da mediação oficial. Em contrapartida, a Comunidade Sant'Egidio estava inserida dentro da mediação principal. Porém, ela não é a mediadora principal, mas participava juntamente com outros atores, da mediação principal, que tinha o Julius Nyerere e posteriormente Nelson Mandela. A falta de coordenação entre esses foi um dos grandes problemas da mediação. A falta de coordenação faz com que a mediação enfraqueça e não tenha um objetivo uno, o que atrapalha enormemente o progresso e o sucesso da mediação.

Também na resolução das reais causas do conflito do Burundi, os mediadores foram incapazes de resolver a questão da propagação do medo e terror em toda a sociedade e da desconfiança entre as partes. Eles também não conseguiram implementar instituições de resolução de conflito e transformar realmente o conflito para político. $\mathrm{O}$ acordo era fraco e poroso, não determinando quem realizaria a transição para o novo regime e sem conseguir cobrir todas as questões do conflito. O genocídio de 1972, por exemplo, continua apagado na história burundinesa.

Outro erro gravíssimo, por parte dos mediadores era não negociar com todas as partes do conflito. A falta dos dois principais grupos armados de oposição na negociação demonstrava a fraqueza da mediação e a falta de maturidade do conflito. O mediador precisa saber qual o momento maduro do conflito para intervir ou arrumar mecanismos de englobar todas as partes na mediação. Não é aceitável um acordo de paz onde os principais grupos não estão presentes, pois o acordo não vai conseguir ser implementado e tende a falhar.

A percepção das partes do conflito e a visão internacional mantiveram-se depois da mediação, sendo este um dos principais problemas que a mediação deveria resolver. Os Hutus e Tutsis mantiveram o seu relacionamento de ódio, 
desconfiança e medo. Os dois grupos tinham medo das consequências de ter o outro no poder e não acreditavam que podiam lutar politicamente pelas suas reivindicações. Apesar de os grupos mais pacifistas dos dois lados tentarem a via política, os extremistas continuaram com força e um novo conflito é iminente.

Isto é parcialmente em decorrência da falta de um trabalho das ONGs no modelo piramidal. Além disso, os projetos das ONGs na mediação centraram-se em um único membro do CCR e com lideranças dentro de um ambiente de animosidade, sem a preocupação de afastar os líderes desse ambiente e de envolver outras parcelas da população.

O envolvimento internacional, principalmente dos países africanos, aconteceu durante o conflito. No entanto, a participação deles também não conseguiu resolver os problemas latentes no Burundi. Não foi possível mudar a percepção entre as partes em conflito, entre as etnias conflitantes e nem mesmo dos líderes frente à população. O Burundi continua sendo um Estado falido com um dos maiores níveis de corrupção do mundo. O Estado é sequestrado e o governo só se utiliza dos seus recursos para beneficio próprio.

Conclui-se, assim, que as ONGs contribuem consideravelmente para a solução dos conflitos complexos. Apesar de suas limitações, como todos os outros tipos de mediador têm. As ONGs são uma alternativa para casos nos quais não interessam os Estados, organizações internacionais e regionais agir diretamente. Observa-se ainda que os conflitos complexos precisam ser analisados separadamente dos demais conflitos devido às suas especificidades. O modelo piramidal em conjunto com uma estratégia de mediação flexível e adaptável é o mais aconselhável para a mediação nesses casos. E nesse contexto as ONGs são as melhores mediadoras, visto que elas conseguem trabalhar de maneira menos burocrática, mais dinâmica, criativa, informal e flexível. Além disso, as ONGs possuem uma maior inserção na sociedade conseguindo assim envolver todos os níveis sociais na mediação. Outro fator relevante é a possibilidade delas se envolverem com os atores ilegítimos na mediação, conseguindo assim levar todos os atores do conflito para a mesa de negociação.

No entanto, as ONGs, muitas vezes, não conseguem suprir todas as necessidades apresentadas pelo conflito e é necessária a participação de mais de um tipo de mediador, visto que todos os mediadores possuem limitações e vantagens e eles não conseguem suprir sozinhos todas as necessidades de uma 
mediação eficaz. Então, esses atores precisam trabalhar em coordenação, visando o mesmo objetivo e concordando com a estratégia adotada, pois só assim conseguem responder de forma segura aos desafios do conflito. Diante desta situação o mediador principal não precisa ser o mais poderoso, mas é fundamental que ele consiga angariar apoio e coordenar os mais diferentes atores. Essa função pode ser perfeitamente desempenhada pelas ONGs, considerando uma das suas principais vantagens ter a capacidade de se envolver com os mais diferentes atores, podendo ir desde um grupo armado ilegítimo a presidentes e Secretário das Nações Unidas. 


\section{7.}

\section{Referências Bibliográficas:}

AALL, Pamela. NGO and Conflict Management. Peaceworks 1996.

Disponível

em: $<$ http://dspace.cigilibrary.org/ispui/bitstream/123456789/14874/1/NGOs\%2 0and\%20Conflict\%20Management.pdf?1> Acessado em: novembro de 2011.

AALL, Pamela. The Power of nonofficial actors in conflict management. In: CROCKER, C.; HAMPSON, F.; AALL, Pamela (Orgs.). Leashing the Dogs of War: Conflict Management in a Divided World. Washington D.C.: United State International of Peace,2007, p. 477-493.

ACADEMIC LEADERSHIP SUPPORT. Disponível em: $<$ http://www.ohrd.wisc.edu/onlinetraining/resolution/aboutwhatisit.htm\#wha tisconflict> Acessado em: fevereiro de 2012.

ACORDO DE PAZ E RECONCILIAÇÃO DE ARUSHA PARA O BURUNDI. Disponível em: < http://www.issafrica.org/AF/profiles/Burundi/arusha.pdf> Acessado em: janeiro de 2012.

AFRICAN NATIONAL CONGRESS. What is African National Congress?. Disponível em: < http://www.anc.org.za/show.php?id=172> Acessado em: janeiro de 2012.

AGGESTAM, Karin. Conflict Prevention: Old Wine in New Bottles?. In: CAREY, Henry; RICHMOND, Oliver. Mitigating Conflict The Role of NGOs. Londres: Frank Cass, 2003, pp. 12-23.

ANDERSON, Mary B.; OLSON, Lara. Using the Findings. In: Confronting War: Critical Lessons for Peace Practitioners. Cambridge: The Collatorative for Development Action, 2003. Disponível em: < http://www.skr.org/download/18.4bb0052912fd16044aa80004675/confront ingwar Pdf1.pdf> Acessado em: março de 2012.

ANGOLA PRESS. Vaticano aceira renúncia de Bispo da Beira por limite de idade. 17 de janeiro de 2012. Disponível em: $<$ http://www.portalangop.co.ao/motix/pt pt/noticias/africa/2012/0/3/Vatican o-aceita-renuncia-bispo-Beira-por-limite-idade,fcfc80da-2aab-404c-9d28b3ed74ef24a3.html> Acessado em: 10 de fevereiro de 2012.

ASSOCIAÇÃO DE COMÉRCIO E INDÚSTRIA. O quadro legal: para importação e exportação de Moçambique. 2008. Disponível em: $<$ http://www.acismoz.com/lib/services/publications/docs/Beira\%20Importa cao\%20Exportaca0\%20Edica0\%201\%20Portugues.pdf> Acessado em: fevereiro de 2012. 
AYRES, R. William. Mediation International Conflicts: Is Image Change Necessary, Journal of Peace Research, 1997, v. 34, n. 4, pp. 431-447.

AZAR, Edward. The Management of Protracted Social Conflict: Theory and Cases. Aldershot: Dartmouth, 1990.

BARNETT, Michael. Partners in Peace? The UN, Regional Organizations, and Peacekeeping. Review of International Studies, 1995, v.21, n.4, p.411-433.

BARTOLI, Andrea. Learning from the Mozambique peace process: The role of Community of Sant'Egidio. In: FISHER, Ronald J. (ed) Paving the way: contributions of interactive conflict resolution to peacemaking. Lexington Books, 2005, pp. 79-104

BATER, Shane Joshua. A Deep Look into the Recent Eletions in Aceh. The Jakarta Post, 28 de abril de 2009. Disponível em: < http://www.thejakartapost.com/news/2009/04/28/a-deeper-look-recentelections-aceh.html> Acessado em: abril de 2012.

BERCOVITCH, Jacob. International Mediation and Intractable Conflict. In: BURGESS, Guy; BURGESS, Heide. Conflict Research Consortium. Beyond Intractability. Boulder: University of Colorado, 2004. Disponível em: <http://www.beyondintractability.org/essay/med intractable conflict/> Acessado em: novembro de 2011.

BERCOVITCH, Jacob. Mediation in international conflict: An Overview of Theory, A Review of Practice. In: ZARTMAN, I. William, RASMUSSEN, J. Lewis (Org.). Peacemaking in International Conflict: Methods and Techniques. United State Institute of Peace Press: Washington, 1999. p. 125-153.

BERCOVITCH, Jacob. Social Conflict and Third Party: Strategies of Conflict Resolution. Boulder, Colorado: Bowker Publishing Co., 1984.

BERCOVITCH, Jacob; ELGSTRÖM, Olé. Culture and international mediation: exploring theoretical and empirical linkages. 2001. Disponível em:http://www.jrnl.canterbury.ac.nz/staff pages/ibercovitch/publications/cu lturelatest.pdf Acessado em: Agosto de 2011.

BERCOVITCH, Jacob; HOUSTON, Allison. The Study of International Mediation: Theoretical Issues and Empirical Evidence. In: BERCOVITCH, Jacob (Org.). Resolving International Conflict: The Theory and Practice Mediation. Lynne Rienner Pub, 1996, pp. 11-38.

BERCOVITCH, Jacob; HOUSTON, Allison. Why do they do it like this?: An Analysis of the Factors Influencing Mediation Behavior in International Conflicts. Journal of Conflict Resolution, 2000. v.44, n.2, pp. 170-202. 
BERCOVITCH, Jacob; SCHNEIDER, Gerald. Who mediates? The political economy of international conflict management. Journal of Peace Reseach, Oslo: Journal of Peace, 2000. v.37, n.2, pp. 145-165.

BRACHET, Juana; WOLPE, Howard. Conflict-Sensitive Development Assistance: The Case of Burundi. Estados Unidos da América: Conflict Prevention \& Reconstruction \& Social Development Department, 2005

BUTLER, Michael J. International Conflict Management. Nova York: Routledge, 2009.

BRÜCK, Tilman. Guerra e desenvolvimento em Moçambique. Análise Social, 1998. v. 33, pp. 1019-1051.

CARMENT, David. Assessing state failure: implications for theory and policy. Third World Quartely, 2003. v. 24, n. 3, pp. 407-427.

CENTER FOR CONFLICT RESOLUTION ${ }^{\mathrm{a}}$. The Center for Conflict Resolution (CCR): Forty Years of Peace building. Disponível em: $<$ http://www.ccr.org.za/index.php?option=com content\&view=article\&id=3 98\&ltemid=127> Acessado em: janeiro de 2012.

CENTER FOR CONFLICT RESOLUTION ${ }^{b}$. Annual Report, 2009/2010. Disponível em:<http://www.ccr.org.za/images/pdfs/CCRAR09 10nov2011.pdf > Acessado em: janeiro de 2012

CENTER FOR CONFLICT RESOLUTION ${ }^{c}$. CIPS Training interventions. Disponíveis em: $<$ http://www.ccr.org.za/index.php?option=com content\&view=article\&id=3 96\&ltemid $=75>$ Acessado em: janeiro de 2012

CENTER FOR CONFLICT RESOLUTION ${ }^{d}$. The Policy Development and Research Project. Disponíveis em: $<$ http://www.ccr.org.za/index.php?option =com content\&view=article\&id $=5$ 8\&ltemid=76> Acessado em: janeiro de 2012.

CENTER HENRY DUNANT FOR HUMANITARIAN DIALOGUE. About the HD Center. Disponível em <http://www.hdcentre.org/about $>$ Acessado em: 08 de fevereiro de 2012.

CHIGAS, Diana. Capacities and Limits of NGO as Conflict Managers. In: CROCKER, C.; HAMPSON, F.; AALL, Pamela (Orgs.). Leashing the Dogs of War: Conflict Management in a Divided World. Washington D.C.: United State International of Peace,2007, pp. 553-581.

CITY OF HELSINKI. About Helsinki. Disponível em: < http://www.hel.fi/hki/Helsinki/en/Etusivu > Acessado em: fevereiro de 2012. 
CLAPHAM, Andrew. Non-State Actors. In: CHETAIL, Vicent. PostConflict Peacebuilding. Nova York: Oxford University Press, 2009, pp. 200-212.

COMUNIDADE SANT'EGIDIO. The "method" of Santo Egidio: Algeria, Guatemala, Balkan. Disponível em: http://www.santegidio.org/en/pace/pace4.htm Acessado em: dezembro de 2011.

COMUNIDADE SANT'EGIDIO SITE. Disponível em: < http://www.santegidio.org/index.php?pagelD=2\&idLng=1066> Acessado em: novembro de 2011.

CONFLICT MANAGEMENT INITIATIVE. Mission Statement. Disponível em: <http://www.cmi.fi/mission.html> Acessado em: 09 de fevereiro de 2012a.

CONFLICT MANAGEMENT INITIATIVE SITE. Disponível em: < http://www.cmi.fi/> Acessado em: fevereiro de 2012b.

CONFLICT MANAGEMENT INITIATIVE. Frequently asked questions. Disponível em: <http://www.cmi.fi/faq.html> Acessado em: 09 de fevereiro de 2012c.

CONFLICT MANAGEMENT INITIATIVE. Aceh Negotiation in 2005. Disponível em: <http://www.cmi.fi/aceh.html> Acessado em: fevereiro de 2012d.

COOPER, Andrew; HOCKING, Brian. Governmental, Non-governmental Organization and the Re-calibration of Diplomacy. Global Society, 2000 , v. 14 , n 3. pp. 361-376.

CREEKMORE, Marion V.; TAULBEE, James Larry. NGO Mediation: The Carter Center. In: CAREY, Henry; RICHMOND, Oliver. Mitigating Conflict The Role of NGOs. Londres: Frank Cass, 2003, pp. 156-171.

DIAMOND, Louise; MCDONALD, John. Multi-Track Diplomacy: A Systems Approach to Peace. Kumarian Press, 1996

DEBRIX, François. A Taste of Their Own Medicine: Medical Assistance and Humanitarism as Substitutes for UN Peacekeeping. In: ReEnvisioning Peacekeeping: The United Nation and Mobilization of Ideology. Regents of University of Minnesota, 1999. pp. 171-208.

ELECTORAL INSTITUTE FOR THE SUSTENTABILITY OF DEMOCRACY IN AFRICA. Burundi: Second Republic (1976-1987). Disponível em: http://www.eisa.org.za/WEP/buroverview6.htm Acessado em: março de 2012. 
EVANS-KENT, Bronwyn; BLEIKER, Roland. Peace Beyond the State? NGOs in Bosnia and Herzegovina. International Peacekeeping, v 10, n 1, 2003, pp. 103-119.

FERREIRA, Aurélio Buarque de Holanda. Dicionário Aurélio. Editora Positivo, 2010, 960p.

GRIGON, François. Élections au Burundi: Prevenir Toute Escalade de Violence. International Crisis Group. 3 de março de 2010. Não paginado. Disponível em: http://www.crisisgroup.org/en/regions/africa/centralafrica/burundi/elections-au-burundi-prevenir-toute-escalade-deviolence.aspx Acessado em: março de 2012.

HOFFMAN, Mark. Critical Theory and the inter-paradigm debate. Journal of International Studies, 1987. v.16, n.2, pp. 231-250

HOLANDA FERREIRA, Aurélio Buarque de. Dicionário Aurélio 7: Nova Ortografia 100 anos. Rio de janeiro: Nova Fronteira, 2012.

HUBER, Konrad, The HDC in Aceh: Promises and Pitfalls of NGO Mediation and Implementation. Washington D.C., East-West Center Washington, 2004, 101p. Disponível em: $<$ http://scholarspace.manoa.hawaii.edu/bitstream/handle/10125/3505/PS0 09.pdf? sequence=1> Acessado em: novembro de 2011.

HUMAN RIGHT WATCH. Burundi: Seek Justice for War crimes Victims. 13 de agosto de 2009. Disponível em: $<$ http://www.hrw.org/en/news/2009/08/13/burundi-seek-justice-war-crimesvictims > Acessado em: março de 2012

HUMAN RIGHT WATCH. Burundi: Violence, Right Violations Mar Eletions. 01 de julho de 2010. Disponível em: $<$ http://www.hrw.org/en/news/2010/07/01/burundi-violence-rightsviolations-mar-elections > Acessado em: março de 2012.

HUMAN RIGHT WATCH. Human Rights and Humanitarian Law Violations,2003. Disponível em: $<$ http://www.hrw.org/reports/2003/indonesia1203/5.htm\# Toc58915047> Acessada em: fevereiro de 2012.

HUME, Cameron. Ending Mozambique's war: The role of mediation and good offices. United State Institute of Peace Press, 1994.

JETT, Denis. Why Peacekeeping Fails. New York: Palgrave, 2007.

JONES, Deiniol. Cosmopolitan mediation?. Manchester: Manchester University Press, 1999. 
KALDOR, Mary. New \& Old Wars: organized violence in a global era. Stanford: Stanford University Press, 2001, p. 69-89.

KAYNE, D.D. Track Two Diplomacy and Regional Security in the Middle East. International Negotiation, 2001, v. 6. n1, pp. 49-77

KELMAN, Herbert C. The Rule of the Scholar-Practitioner in International Conflict Resolution. International Study Perspective, 2000, pp. 273-288.

KELMAN, Hebert C. Coalitions across Conflict Line: The Interplay of conflict within between Israeli and Palestinian Communities. In: S.

KLEIBOER, Marieke. Understanding success and failure of international mediation. Londres: The journal of Conflict Resolution, 1996. pp. 360-389.

KRIESBERG, Louis. Contemporary Conflict Resolution Applications. In:

CROCKER, C.; HAMPSON, F.; AALL, Pamela (Orgs). Leashing the Dogs of War: Conflict Management in a Divided World. Washington D.C.: United State International of Peace,2007, pp. 455-476.

LALÁ, Anícia; OSTHEIMER, Andréa. Transição e consolidação da democracia em África: Como limpar as nódoas do processo democrático? Maputo: Konrad-Adenauer-Stiftung, 2003. Disponível em http://www.iese.ac.mz. Acessado em dezembro de 2009.

LANZ, David; SGUAITAMATTI, Damiano; SIEGFRIED, Matthias. Towards Realizing the Strengths and Mitigating the Challenges of NGO Mediators (Final Report of Consultation Process)". Center for Security Study e Swisspeace, 2009. Disponível em:http://www.swisspeace.ch/typo3/fileadmin/user upload/pdf/msp/NGO mediators Final Report WEB.pdf Acessado em: março de 2012.

LEDERACH, John Paul. Building Peace: Sustainable Reconciliation in Divided Societies. Washington D.C.: United States Institute of Peace, 1997.

LEITENBERG, Milton. Deaths in Wars and Conflicts in the $20^{\text {th }}$ Century. Cornell University: Peace Study Program. Ocasional Paper 3ed, 2003, 2005, 2006. Disponível em: < http://www.cissm.umd.edu/papers/files/deathswarsconflictsjune52006.pdf> Acessada em: maio de 2012.

LEMARCHAND, René. The Burundi Genocide. In: TOTTEN, Samuel; PARSONS, William S.; CHARNY, Israel W.(Eds.). Century of Genocide: Eyewitness Accounts and Critical Views (Garland Reference Library of Social Science). Routledge, 2009, pp. 406-427. 
MAGNOLI, Demetrio. História da Paz. São Paulo: Editora Contexto, 2008. 448p.

MAKOBA, Johnson W,; NDURA, ELAVIE. The Roots of Contemporary Ethnic Conflict and Violence in Burundi. In: SAHA, SantosH C. (Ed). Perspective on Contemporary Ethnic Conflict. Oxford: Lexington, 2006, p. 295-310.

MANNING, Carrie; MALBROUGH, Monica. Learning the Right Lessons from Mozambique's Transition to Peace. Taipé: Taiwan Journal of Democracy, Vol. 5, No.1, 2008. Disponível em http://www.tfd.org.tw/english/tid.php. Acesso em: novembro 2012.

MCKEON, Celia. Civil Society: Participating in Peace Processes. In: VAN TONGEREN, Paul; BRENK, Malin; HELLEM, Marte; VERHOEVEN, Juliette(Orgs). People Building Peace II: Sucessful Stories of Civil Society. London, 2005. pp. 567-575.

MELLO, Celso D. de Albuquerque. Curso de Direito Internacional Público. 11 ed. Rio de Janeiro: Renovar, 1997.

MERRILLS, J.G. International dispute settlement. 3ed. Cambridge University Press, 2000.

MIALL, Hugh; RAMSBOTHAM, Oliver; WOODHOUSE, Tom. Introduction to Conflict Resolution; Concepts and Definitions. In: Contemporary Conflict Resolution. Cambridge: Polity Press, 2009. p. 3-105.

MILLER, Michelle Ann. Rebellion and Reform in Indonésia: Jakarta's Security and Autonomy Policies in Aceh. Routlerdge, 2004, 234p.

MINISTÉRIO DAS RELAÇÔES EXTERIORES. Burundi. Disponível em: http://www2.mre.gov.br/deaf/daf 3/burundi2.htm Acessado em: março de 2012.

MITCHELL, Chris. External Peacemaking Initiative and International Conflict. In: MIDLARSKY, Manus. The Internationalization of Communal Strife. Londres: Routledge, 1992.

MÜNKLER, Herfried. What is new about new wars?. In: The New Wars. Polity, 2004.

NATSIOS, Andrew S.. An NGO Perspective. In: ZARTMAN, I. William (Org.). Peacemaking in International Conflict: Methods and Techniques. Unites State Institute of Peace: Washington, 2007. pp. 337361.

NDIKUMANA, Leone. Institutional Failure and Ethnic Conflicts in Burundi. African Studies Association. 1999. 
NIJIMBERE, Léonidas. Insider Mediators: Exploring Their Key Role in Informal Peace Process.: The Burundi Peace Process. Berghof Foundation for Peace Process, 2004, pp. 1- 5. Disponível em: $<$ http://www.berghof-

peacesupport.org/publications/MED Insider Mediators Burundi.pdf> acessado em: abril de 2012.

ODENDAAL, Andries. Ethnic Conflict and Its Managements. Cape Town, South African. Junho, 1998. Disponível em: http://ccrweb.ccr.uct.ac.za/archive/staff papers/odendaal ethnic.html Acessado em:março de 2012.

ODENDAAL, Andries; HONWANA, João Bernado. 0 "Center for Conflict Resolution": uma ONG Sul-Africana. Janus 2005. Disponível em: $<$ http://janusonline.pt/2005/2005 42 12.html $>$ Acessado em junho de 2011.

ORGANIZAÇÂO DAS NAÇÔES UNIDAS. Carta das Nações Unidas. Disponível em: $<$ http://pfdc.pgr.mpf.gov.br/legislacaopfdc/paz/carta nacoes unidas.pdf $>$ Acessado em: agosto de 2011.

ORGANIZAÇÃO DAS NAÇÕES UNIDAS. Resolução S/RES/797 de 1992 do Conselho de Segurança. Disponível em: http://www.un.org/documents/sc/res/1992/scres92.htm Acesso em: dezembro de 2012.

PROJECT PLOUGHSHARES. Armed Conflict Report: Burundi (1988first combat deaths). Janeiro de 2010. Disponível em: http://www.ploughshares.ca/libraries/ACRText/ACR-Burundi.html Acessado em: março de 2012

RADIO NOTICIAS. Perfil de Martti Ahtisaari. Disponível em: < http://www.tsf.pt/Paginalnicial/Vida/Interior.aspx?content id=1025433\&pa ge=-1> Acessado em: 09 de fevereiro de 2012.

RASMUSSEN, Peter Ravn. 'Nation' or 'State' an attempt at definition: An essay on the difference between two concept "nation" and "state", with cautions attempt at definition these terms. 2001. Disponível em: < http://www.scholiast.org/nations/whatisanation.html> Acessado em: fevereiro de 2012.

RATNER, Steven R.; ABRAMS, Jason S. Accountability for Human Rights Atrocities inInternational Law: Beyond the Nuremberg Legacy. Oxford: Oxford University Press, 2ª. ed., 2006.

RICHMOND, Oliver. Devious objectives and the disputants' view of international mediation: A theoretical framework. Oslo: Journal of Peace Research, 1998. v.35, n.6, pp. 707-722. 
RITTBERGER, Volker and BRUHL, Tanja. From International to global governance: Actors, collective decision-making, and the United Nations in the world of the twenty-first century. Global Governance and the United Nations System, 2001, pp 1-47.

RUPIYA, Martin, Historical context: war and peace in Mozambique. Conciliation Resolution: working together for peace, 1998. Disponível em: $<$ http://www.c-r.org/sites/www.c-

r.org/files/Accord\%20Mozambique Historical\%20context.pdf:> Acessado em: fevereiro de 2012

SAMPSON, Cynthia, Religion and peacebuilding. In: ZARTMAN, I. William (Org.). Peacemaking in International Conflict: Methods and Techniques. Unites State Institute of Peace: Washington, 2007. pp. 273316.

SEARCH FOR COMMON GROUND ${ }^{a}$. Search for Common Grounp Selected as one of The Top 100 Best NGOs in the World. Disponível em: < http://www.sfcg.org/resources/globaljournal2012.html> Acessado em: fevereiro de 2012.

SEARCH FOR COMMON GROUND. Our Mission and Vision. Disponível em: < http://www.sfcg.org/sfcg/sfcg mission.html> Acessado em: fevereiro de 2012.

SEARCH FOR COMMON GROUND. Search for Common Ground in Burundi: Relatório da Avaliação Independente do Programa (não publicado). Janeiro de 1999.

SEBASTIAN, Leonard C. Realpolitick Ideology: Indonesia's Use of Military Force. Institute of Southeast Asian Studies, 2004, 600p.

SMITH, James D.D. Mediator Impartiality: Banishing the Chimera. Oslo: Journal of Peace Research, 1994. v.31, n.4, pp. 445-450.

STANFORD ENCYCLOPEDIA OF PHILOSOPHY. Disponível em: $<$ http://plato.stanford.edu/entries/war/\#5> Acessado em: fevereiro de 2012.

STROBEL, Warren P. The CNN Effect: How much influence does the 24-hour news network really have on foreign policy?. American Journalism Review, $1996 . \quad$ Disponível em: < http://www.air.org/article.asp?id=3572> Acessado em: janeiro de 2012.

TAYLOR, Jean Gelman. Indonesia: Peoples and History. Yale University Press, 2003,

THE ECONOMIST. Hoping for Peace to Return: A former independent movement turn on its own. 14 de abril de 2012. Disponível em: 
<http://www.economist.com/node/21552623> Acessado em: março de 2012.

THE ECONOMIST. A Sour Mood: Civil Strife Beckons Again. The economist, 10 de março de 2012. Disponível em: < http://www.economist.com/node/21549998> Acessado em: março de 2012.

VAKIL, Anna C. Confronting the Classification Problem: Toward a Taxonomy of NGO. World Development, dezembro de 1997, v. 25 n. 12, pp. 2057-2070.

ZARTMAN, I. William; TOUVAL, Saadia. International Mediation. In: CROCKER, C.; HAMPSON, F.; AALL, Pamela (Orgs.). Leashing the Dogs of War: Conflict Management in a Divided World. Washington D.C.: United State International of Peace, 2007, pp. 437-454

ZARTMAN, I William; TOUVAL, Saadia. International Mediation: Conflict resolution and power politics. Journal of Social Issue, 1985. v. 42, n 2. pp. 27-45.

WALL, J.A., Jr.; LYNN, A. Mediation: A current review. Journal of Conflict Resolution. 1993. v.37, n.1, pp. 160-194.

WALLENSTEEN, Peter. Understanding Conflict Resolution: War, Peace and the Global System. Londres: Sage Publications, 2002. Capítulos 1-6.

WILLETTS, Peter. What is a Non-Governmental Organization?. UNESCO encyclopedia of Life Support System, 2002. Disponível em: < http://www.staff.city.ac.uk/p.willetts/CS-NTWKS/NGO-ART.HTM>

Acessado em: novembro de 2011.

WORCHEL; J., Simpson. Conflict Between People and Groups. Chicago: Nelson-Hall, 1993, pp. 236-258. 